Instituto de Arquitetura e Urbanismo

Universidade de São Paulo

\section{PROGRAMAS HABITACIONAIS E A GESTÃO DOS ILEGALISMOS:}

regularização fundiária e remoções em Londrina-PR

Tese apresentada ao Programa de PósGaduação em Arquitetura e Urbanismo do Instituto de Arquitetura e Urbanismo da Universidade de São Paulo, como parte dos requisitos para a obtenção do título de Doutora em Arquitetura e Urbanismo (Versão corrigida).

Orientadora:

Prof. ${ }^{\text {a }}$ Dr. ${ }^{\text {a }}$ Cibele Saliba Rizek 


\section{AUTORIZO A REPRODUCAO TOTAL OU PARCIAL DESTE \\ TRABALHO, POR QUALQUER MEIO CONVENCIONAL OU ELETRÔNICO, PARA FINS DE ESTUDO E PESQUISA, DESDE QUE CITADA A FONTE}

Ficha catalográfica elaborada pela Biblioteca do Instituto de Arquitetura e Urbanismo com os dados fornecidos pelo(a) autor(a)

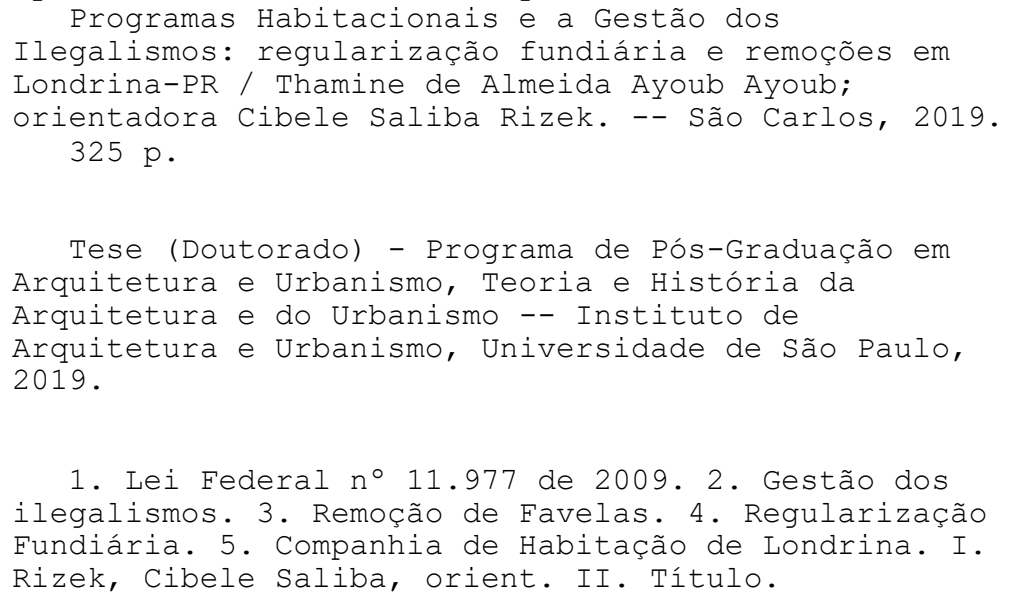

1. Lei Federal n 11.977 de 2009. 2. Gestão dos ilegalismos. 3. Remoção de Favelas. 4. Regularização Fundiária. 5. Companhia de Habitação de Londrina. I. Rizek, Cibele Saliba, orient. II. Título. 


\section{FOLHA DE JULGAMENTO}

Candidato(a): Thamine de Almeida Ayoub Ayoub

Título da tese: "Programas habitacionais e a gestão dos ilegalismos: regularização fundiária e remoções em Londrina-PR"

Data da defesa: 16/12/2019

Orientador: Profa. Dra. Cibele Saliba Rizek

Comissão Julgadora:

Resultado:

ubulis. Mer

Profa. Dra. Cibele Saliba Rizek

(IAU/USP)

Não votante

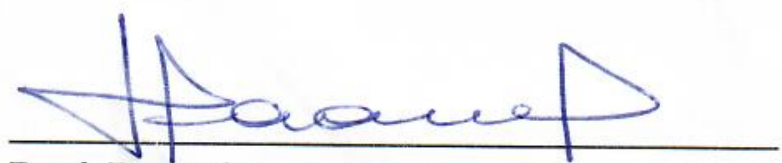

Prof. Dr. Jeferson Cristiano Tavares

APINOUADA (IAU/USP)

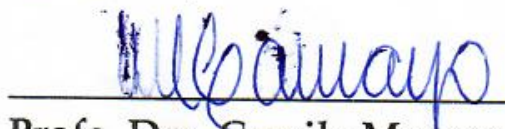

Profa. Dra. Camila Moneno de Camargo

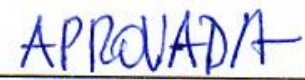
(IAU/USP)

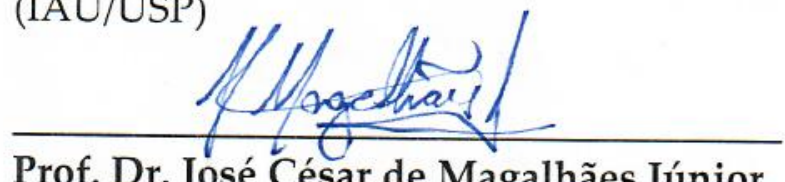

Prof. Dr. José César de Magalhães Júnior (FACAMP)

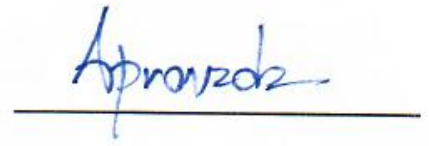

Profa. Dra. Milena Kanashiro (UEL)

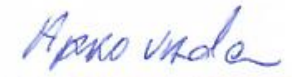

Profa. Dra. Ideni Terezinha Antonello (UEL)

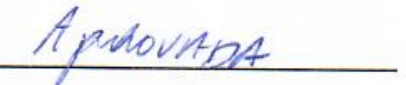

Coordenador e Presidente da Comissão de Pós-Graduação do Programa de PósGraduação em Arquitetura e Urbanismo: Prof. Dr. Tomás Antonio Moreira. 

Para Hélène e Oneida 



\section{Agradecimentos}

Este período em que cursei o doutorado foi repleto de desafios e, sem dúvida, esta conclusão só foi possível graças a todo apoio que recebi de professores, colegas, amigos e familiares. Posso dizer que esses anos foram intensos, me dividir entre a docência, as viagens a São Carlos e a pesquisa de campo, foi, no mínimo, desafiador. Ao mesmo tempo, foram tantos os incentivos, palavras e gestos de apoio que o sentimento de gratidão nesta etapa final é imenso.

O aprendizado e o acolhimento foram tão grandes que, para além do cansaço físico, as viagens a São Carlos foram renovadoras, energizantes. As atividades dos grupos de pesquisa, as disciplinas e orientações sempre me fizeram retornar com mais ânimo e motivação para minhas atividades.

Primeiro, agradeço imensamente à minha orientadora, Profa Cibele Saliba Rizek, por aceitar me orientar nesta pesquisa, por acolher minhas dificuldades e inseguranças, e por me apoiar e me incentivar em todo o processo. Minha admiração pela pessoa e pela profissional só aumentaram. Além do carinho e da disponibilidade, a Cibele me apresentou um caminho que me fez repensar completamente meu papel como pesquisadora e professora, o trabalho de campo, e o rigor científico. É difícil colocar em palavras o aprendizado deste período, mas posso dizer que devo muito a ela meu crescimento profissional e pessoal nestes últimos anos.

Agradeço ao Prof. Manoel Alves e à equipe do LEAUC - Laboratório de Estudos do Ambiente Urbano Contemporâneo pela oportunidade de participar das atividades, discussões e eventos e, em especial, agradeço aos colegas Esther, Maíra, Marília, Erica, Thainá, Andrei e Maísa pelo acolhimento e por dividirem comigo os momentos de alegrias, aflições, medos e realizações.

Agradeço ao Prof. Caio Santo Amore pelas contribuições na banca de qualificação. 
Agradeço à Profá Lucia Zanin Shimbo pela análise precisa do meu trabalho e pelas enriquecedoras contribuições na banca de qualificação.

Agradeço à equipe da Cohab-LD pelo fornecimento dos documentos, pela recepção com atenção e disponibilidade, em especial aos funcionários do extinto Setor de Regularização Fundiária e do Departamento Social.

Agradeço ao Instituto de Arquitetura e Urbanismo da USP de São Carlos, aos funcionários e corpo docente, pela infraestrutura de alta qualidade e gratuita. Em especial, agradeço à Mara e à Flávia pela disponibilidade e paciência. Em tempos de ataque às universidades públicas, deixo registrado meu agradecimento pela oportunidade de cursar o doutorado em uma escola pública e gratuita.

Não posso deixar de agradecer aos meus colegas da UNOPAR, em especial nossa coordenadora e amiga Renata Basso, que em meio a tantos desafios, me incentivaram e apoiaram durante todos esses anos.

Agradeço aos professores do Departamento de Arquitetura e Urbanismo da Universidade Estadual de Londrina por todo apoio que recebi desde o primeiro ano de doutorado para que eu pudesse conciliar as viagens e estadias em São Carlos com minhas atividades como professora colaboradora. Em especial, agradeço ao professor José Luiz Faraco pelo incentivo e motivação para que eu prestasse o processo seletivo de doutorado; aos professores Gilson Bergoc e Elisa Zanon e todos os colegas do Projeto de Extensão "Apoio à análise do Estudo de Impacto de Vizinhança" pelas discussões e pelas contribuições ao meu trabalho e pelo apoio para que eu conseguisse finalizar a tese nestes últimos meses; à Prof.a Milena Kanashiro que, desde o mestrado, me deu total apoio, minha mestre e amiga.

Agradeço à Profa Vera Suguihiro e aos colegas do Projeto de Extensão “Juventude e violência: da violação à garantia de direitos" pelo auxílio na pesquisa documental na Cohab-LD. Agradeço também ao grupo de pesquisa "Direito à Cidade" pelas discussões teóricas.

Agradeço aos meus amigos Louisa Savignon, Mariana Lopes, Lígia Mauá, Lívia Roveri, Livia Bodnar, Juliana Moron e Guilherme Mesquita pela amizade, pelo carinho, 
pelo incentivo, pelas discussões, e por me ouvirem nos meus momentos de angústia e de descoberta.

Agradeço ao Renato pelo cuidado e pelo amor.

Agradeço à minha família, em especial aos meus pais, meus maiores incentivadores. 

"Os direitos de propriedade privada sustentam a casa própria, e os estados capitalistas apoiaram por diversos meios (desde os subsídios ativos até a propaganda e à retórica do sonho da casa própria), de maneira sistemática e crescente, a expansão da casa própria a mais setores da população. O objetivo desse apoio é, em parte, garantir o crescimento contínuo do mercado imobiliário como terreno de acumulação ativa e lucrativa de capital, mas ele também tem uma função ideológica crucial, consolidando o apoio popular e populista à estratégia de fornecer valores de uso por meio dos mecanismos de valor de troca: em outras palavras, o apoio à via capitalista" (Harvey, 2016, p.56).

“Há uma política reconhecida como legítima, quando nada porque ninguém questiona a possibilidade de fazer de outra maneira, e porque não é questionada. Esses atos políticos legítimos devem sua eficácia à sua legitimidade e à crença na existência do princípio que os fundamenta" (Bourdieu, 2014, P.39). 



\section{Resumo}

Ayoub, Thamine de Almeida Ayoub. Programas habitacionais e a gestão dos ilegalismos: regularização fundiária e remoções em Londrina-PR. Tese de Doutorado - Instituto de Arquitetura e Urbanismo, Universidade de São Paulo. São Carlos, 2019.

Esta tese trata da política habitacional de Londrina-PR, entendida aqui como a concepção e execução de programas e demais formas de atendimento da demanda habitacional realizada pela Companhia de Habitação de Londrina - Cohab-LD -, desde sua criação. A pesquisa consiste em uma investigação sobre o andamento da política habitacional municipal após a regulamentação dos programas habitacionais instituídos pela Lei Federal no 11.977/2009: o Programa Minha Casa Minha Vida - PMCMV - e o Programa de Regularização Fundiária, e tem como centro da análise o programa de regularização fundiária de interesse social executado na gestão municipal 2013-2016. A partir de incursões de caráter etnográfico na Cohab-LD, a pesquisa parte da constatação de que a regularização fundiária não aparece como uma alternativa às remoções decorrentes dos programas habitacionais, mas está articulada a um modo de operar que tem o desfavelamento como uma verdade instituída na política habitacional. As numerosas remoções que ocorreram associadas à implantação do PMCMV, e os números e procedimentos referentes ao programa de regularização fundiária ilustram esse processo e revelam um deslizamento no conceito da regularização fundiária enquanto instrumento da política habitacional. Nesse sentido, o objetivo principal do trabalho é analisar como os programas habitacionais foram utilizados para gerir as ocupações irregulares localizadas na área urbana de Londrina, pelas remoções de favelas ou pela regularização da situação dos assentamentos informais. A proposta da análise está baseada na ideia Foucaultiana de que os ilegalismos urbanos não são combatidos, mas são geridos pelo Estado por meio de complexos mecanismos que visam garantir o controle sobre os conflitos em torno da ocupação e apropriação do espaço urbano. Um dos desdobramentos da pesquisa consiste na identificação dos Cartórios de Registro de Imóveis como agente central do Programa de Regularização Fundiária e na dimensão neoliberal incorporada nos procedimentos de legalização que tem ofuscado a luta política historicamente associada a esse instrumento. Dessa forma, a pesquisa localiza a política habitacional em uma dinâmica do governo dos corpos e da população, construindo a tese de que os programas habitacionais, articulados às verdades construídas no campo habitacional por meio de discursos, leis e práticas constituem um dispositivo que permite à Cohab-LD gerir diferencialmente os ilegalismos urbanos pautada na lógica rentista da propriedade privada da terra.

Palavras-chave: Programas habitacionais; Gestão dos ilegalismos; Lei Federal no 11.977/2009; Regularização Fundiária; Remoções; Cartório de Registro de Imóveis; Companhia de Habitação de Londrina. 



\section{Abstract}

Ayoub, Thamine de Almeida Ayoub. Housing programs and management of illegalisms: landholding regularization and removals in Londrina-PR. Doctoral Thesis - Architecture and Urbanism Institute, University of São Paulo. São Carlos, 2019.

This doctoral thesis addresses the housing policy in Londrina-PR, perceived here as the conception and execution of programs and further ways of attending the housing demand organized by Londrina's Housing Company - Cohab-LD -, since its creation. The research consists of an investigation of the development of the municipal housing policy after the regulation of housing programs instituted by the Federal Law no. 11.977/2009: "Minha Casa Minha Vida" Program - PMCMV - and the Landholding Regularization Program, and the main focus of this analysis is the landholding regularization program of social interest executed in the 2013-2016 municipal management. From incursions of ethnographic nature in Cohab-LD, the research derives from the acknowledgement that the landholding regularization is not considered as an alternative to the removals resulting from the housing programs, but it is in fact articulated to a mode of operation that has the removal of slums as an instituted truth in the housing policy. The numerous removals that took place associated with the implementation of PMCMV, and the data and procedures regarding the Landholding Regularization Program illustrate this process and reveal a slippage in the concept of landholding regularization such as an instrument of housing policy. In this sense, the main objective of this research is to analyze the ways in which the housing programs were used to manage the irregular occupations located in Londrina's urban area, through slum removals or by regularizing the situation of informal settlements. This analysis proposal is based on the Foucaultian idea that urban illegalisms are not combated, but maintained by the state through complex mechanisms that aim to guarantee control over conflicts regarding the occupation and appropriation of urban space. One of the outcomes of the research consists in the identification of the Land Registry Office as the main agent of the Landholding Regularization Program and in the neoliberal dimension incorporated into the legalization procedures that has overshadowed the political struggle historically associated with this instrument. Therefore, the research locates the housing policy on a government dynamics of bodies and population, developing the theory that the housing programs, articulated with the constructed truths in the housing field through discourses, laws, and practices constitute a mechanism that allows Cohab-LD to differentially run the urban illegalisms guided by the rentier logic of private land ownership.

Keywords: Housing Programs; Management of Illegalisms; Federal Law no. 11.977/2009; Landholding Regularization; Removals; Land Registry Office; Londrina's Housing Company. 



\section{Listas}

\section{Lista de figuras:}

Figura 1 - Colonização do Norte do Paraná

Figura 2 - Localização dos principais núcleos urbanos na totalidade do arranjo espacial promovido pela Companhia de Terras

Figura 3 - Localização das principais vilas de Londrina no final da década de 50

Figura 4 - Desenvolvimento dos setores da economia urbana de Londrina entre as décadas

de 50 e 70.

Figura 5 - Avanço das lavouras mecanizadas em Londrina 66

Figura 6 - Crescimento população urbana em Londrina 67

Figura 7 - Bolsões de pobreza em Londrina - década de $90 \quad 69$

Figura 8 - Mapa dos assentamentos informais de Londrina - 2016

Figura 9 - Localização dos CHIS 1970-2000 80

Figura 10 - Imagem aérea da área urbana de Londrina (2019) evidenciando os fundos de vale

$\begin{array}{ll}\text { que cortam a cidade } & 109\end{array}$

Figura 11 - Localização dos empreendimentos FAR - PMCMV faixa 1 em Londrina $\quad 164$

$\begin{array}{ll}\text { Figura 12 - Residencial Vista Bela } & 167\end{array}$

Figura 13 - Origens das famílias removidas para o Res. Vista Bela 175

Figura 14 - Limite do parcelamento do empreendimento da Cia de Terras e as terras de

Francisco Beltrão

Figura 15 - Empreendimentos lançados a partir da década de 2000 na zona leste de Londrina.

Figura 16 - Organograma Cohab-LD 191

Figura 17 - Localização do Jd. São Rafael próxima ao Fundo de Vale 198

Figura 18 - Assentamento das famílias no atual terreno do Jd. São Marcos 203

Figura 19 - Primeiros barracos sendo construídos no Jd. São Marcos 205

Figura 20 - Residências Jd. São Marcos 206

Figura 21 - Residências Jd. São Marcos 206

Figura 22 - Residência vulnerável a alagamentos localizada abaixo do nível da rua $\quad 209$

Figura 23 - Praça do Jd. São Marcos $\quad 212$

Figura 24 - Capela do Jd. São Marcos 212

Figura 25 - Horta comunitária do Jd. São Marcos 213

Figura 26 - Campo de futebol do Jd. São Marcos 214

Figura 27 - Desnível do campo de futebol em relação ao nível da rua, devido ao aterro

$\begin{array}{ll}\text { parcial } & 215\end{array}$

Figura 28 - Ocupação irregular no Jd. São Marcos 216

Figura 29 - Ocupação irregular no Jd. São Marcos 216

$\begin{array}{ll}\text { Figura } 30 \text { - Casa da Vanessa } & 217\end{array}$

Figura 31 - Núcleos regularizados no Programa de Regularização Fundiária da Cohab-LD 224

Figura 32 - Diagrama dos procedimentos da regularização fundiária 228 


\section{Lista de tabelas:}

Tabela 1 - Tipos de Construção em Londrina

Tabela 2 - Unidades habitacionais destinadas ao desfavelamento em Londrina entre 1970 e 1991

Tabela 3 - Empreendimentos habitacionais construídos com recursos do FNHIS, PAC, HBB e OGU em Londrina - Década de 2000

Tabela 4 - Empreendimentos FAR - PMCMV faixa 1 em Londrina

Tabela 5 - Núcleos a serem removidos

Tabela 6 - Núcleos aptos a serem regularizados

Tabela 7 - Núcleos regularizados no Programa de Regularização Fundiária

\section{Lista de gráficos:}

Gráfico 1 - Dinâmica da produção de habitação de interesse social em Londrina, com a referência das administrações municipais e federais $\quad 77$

Gráfico 2 - Fonte dos recursos para produção da Cohab-LD entre 1970 e 2000

Gráfico 3 - Unidades residenciais produzidas nas gestões municipais entre 1970 a 2000.79

Gráfico 4 - Demanda por moradia nas regiões da cidade de Londrina

\section{Lista de Abreviações e Siglas:}

Anoreg - Associação dos Notarios e Registradores do Brasil

ARENA - Aliança Renovadora Nacional

APP - Área de Preservação Permanente

ASPLAN - Assessoria de Planejamento

BID - Banco Interamericano de Desenvolvimento

BNH - Banco Nacional da Habitação

CF - Constituição Federal

CHIS - Conjunto Habitacional de Interesse Social

CNJ - Conselho Nacional de Justiça

COHAB - Companhia de Habitação

COHAB-LD - Companhia de Habitação de Londrina

COHAPAR - Companhia de Habitação do Paraná 
CRAS - Centros Regionais de Assistência Social

CRI - Certificado de Recebíveis Imobiliários

FAR - Fundo de Arrendamento Residencial

FDS - Fundo de Desenvolvimento Social

FGTS - Fundo de Garantia por Tempo de Serviço

FNHIS - Fundo Nacional de Habitação de Interesse Social

HBB-BID - Programa Habitar Brasil/BID

HIS - Habitação de Interesse Social

IAB - Instituto de Arquitetos do Brasil

IPPUL - Instituto de Pesquisa e Planejamento Urbano de Londrina

IPTU - Imposto sobre a Propriedade Predial e Territorial Urbana

IRIB - Instituto de Registro de Imóveis do Brasil

MDB - Movimento Democrático Brasileiro

MP - Medida Provisória

OAB - Ordem dos Advogados do Brasil

OGU - Orçamento Geral da União

PAC - Programa de Aceleração de Crescimento

PAR - Programa de Arrendamento Residencial

PDM - Plano Diretor Municipal

PDS - Partido Democrático Social

PDT - Partido Democrático Trabalhista

PEMAS - Plano Estratégico Municipal para Assentamentos Subnormais

PFL - Partido da Frente Liberal

PLHIS - Plano Local de Habitação de Interesse Social

PMCMV - Programa Minha Casa Minha Vida

PNHU - Programa Nacional de Habitação Urbana

PP - Partido Progressista

PSB - Partido Socialista Brasileiro

PT - Partido dos Trabalhadores

SEMA - Secretaria de Meio Ambiente 
SERFHAU - Serviço Federal de Habitação e Urbanismo

SFH - Sistema Financeiro da Habitação

SOP - Secretaria de Obras e Pavimentação

UAS - Urbanização de Assentamento Subnormal

ZEIS - Zonas Especiais de Interesse Social 


\section{Sumário}

APRESENTAÇÃo $\quad 26$

SOBRE O MÉTODO DA PESQUISA

SOBRE O TEMA DA PESQUISA

SOBRE O OBJETO DA PESQUISA

ESTRUTURA DA TESE

\begin{tabular}{lr} 
PARTE I & 52 \\
\hline
\end{tabular}

LONDRINA, CIDADE PLANEJADA E A GÊNESE DA INFORMALIDADE

MERCADO IMOBILIÁRIO E DESENVOLVIMENTO ECONÔMICO

SEM LUGAR PARA OS POBRES NA CIDADE $\quad 62$

O PAPEL DA COHAB-LD PARA ALÉM DA PRODUÇÃO HABITACIONAL 172

A CRIAÇÃO DAS COHABS E A POLÍTICA DO BNH $\quad 72$

O PRETEXTO DO DESFAVELAMENTO E A ORIGEM DOS ASSENTAMENTOS $\quad 81$

VISÃO EMPRESARIAL E PROPRIEDADE IMOBILIÁRIA $\quad 85$

NOVAS PERSPECTIVAS: MINISTÉRIO DAS CIDADES E A PolítICA NACIONAL DA HABITAÇÃO 90

\begin{tabular}{lr} 
PARTE II & 98 \\
\hline
\end{tabular}

$\begin{array}{lr}\text { ROMPENDO A DICOTOMIA FORMAL/INFORMAL } & 100\end{array}$

A INFORMALIDADE COMO UM MODO DE URBANIZAÇÃO 100

DESFAVELAMENTO COMO RESPOSTA À DICOTOMIA 104

$\begin{array}{lr}\text { O DESFAVELAMENTO COMO VERDADE INSTITUÍDA } & 107\end{array}$

EMBELEZAMENTO E HIGIENISMO-SANITARISMO $\quad 110$

$\begin{array}{lr}\text { OS DISCURSOS E A CONSTRUÇÃO DE VERDADES } & 114\end{array}$

Os Programas Habitacionais da LeI Federal № 11.977/2009 138

A TENTATIVA DE CONSTRUIR UMA POLÍTICA PARA A HABITAÇÃO 138

AS ALTERAÇÕES DA LEI FEDERAL №11.977/2009 E A REVOGAÇÃO dO CAPÍTULO III 148

O PROGRAMA MINHA CASA MINHA VIDA EM LONDRINA E A REMOÇÃO DE FAVELAS 161

O PROGRAMA DE REGULARIZAÇÃO FUNDIÁRIA NA PRÁTICA 188

UM OUTRO AGENTE DA POLÍTICA HABITACIONAL: O CARTÓRIO DE REGISTRO DE IMÓVEIS 233 
OS CARTÓRIOS E O PENSAMENTO PROPRIETÁRIO 


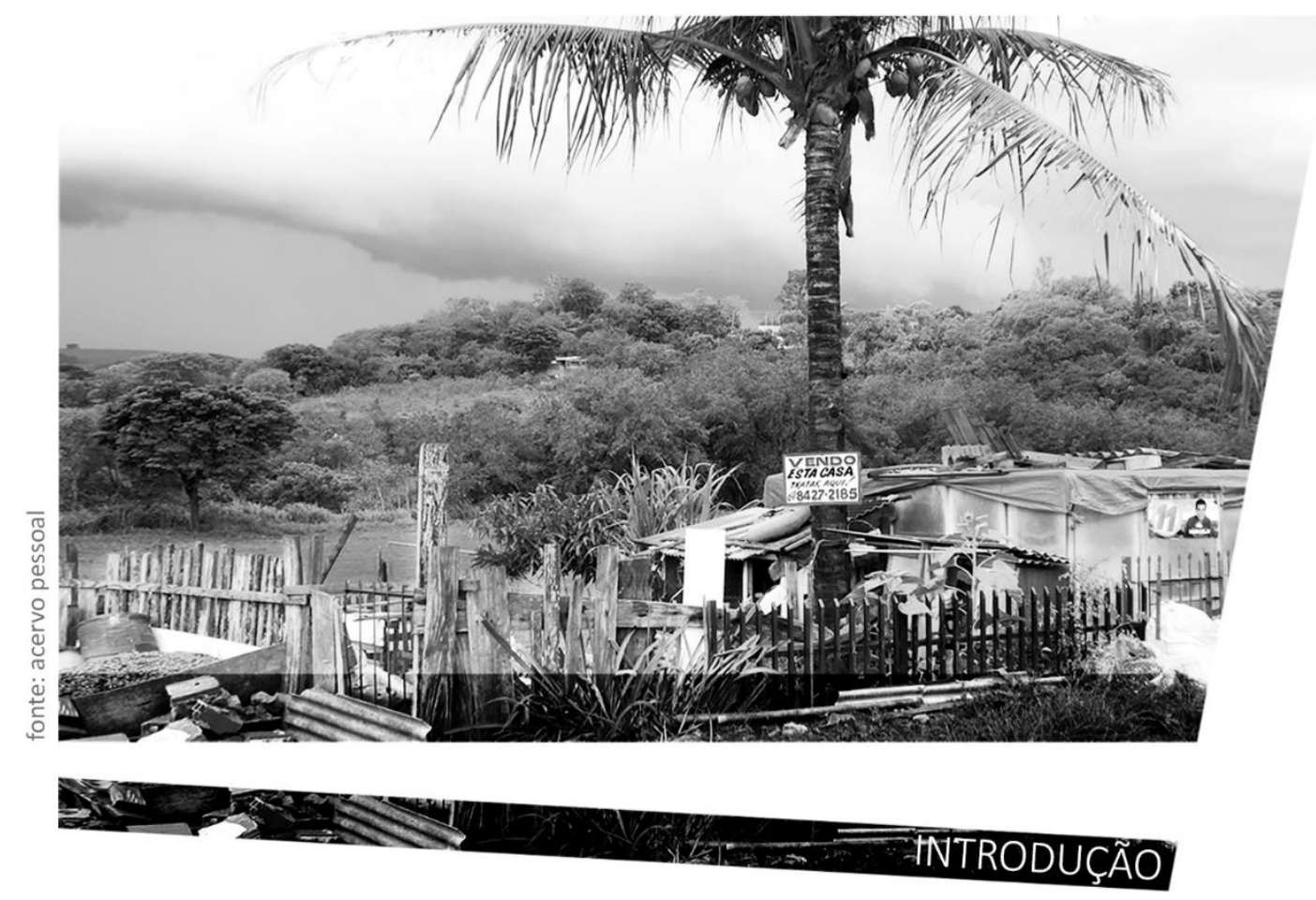




\section{Apresentação}

Esta tese trata da implantação dos programas habitacionais regulamentados pela Lei Federal no 11.977 de 2009 na cidade de Londrina-PR, a saber: o Programa Minha Casa Minha Vida e o Programa de Regularização Fundiária de Interesse Social. O objetivo principal do trabalho é analisar como os programas habitacionais foram utilizados para gerir as ocupações irregulares localizadas na área urbana de Londrina, pelas remoções de favelas ou pela regularização da situação dos assentamentos informais. A proposta desta análise se baseia na ideia de que os ilegalismos urbanos não são combatidos, mas são geridos pelo Estado por meio de complexos mecanismos que visam garantir o controle sobre os conflitos em torno da ocupação e apropriação do espaço urbano.

Nesta análise, a Companhia de Habitação de Londrina - Cohab-LD - tem papel central, por ser o agente responsável pela concepção e execução dos programas habitacionais em Londrina. Por outro lado, ao longo da pesquisa, os Cartórios de Registro de Imóveis se revelaram como agentes centrais no procedimento de regularização fundiária. O estudo do papel desses agentes permite contextualizar a concepção e o direcionamento dos programas nos processos de gestão das ocupações irregulares em Londrina.

A promoção de deslocamentos populacionais decorrentes de remoções de favelas sempre esteve presente na dinâmica da política habitacional brasileira, principalmente justificadas pelo discurso higienista, associadas à produção de conjuntos habitacionais periféricos. Alguns trabalhos têm mostrado que deslocamentos populacionais provocados nas últimas duas décadas por reintegrações de posse violentas estiveram associados a projetos de renovação urbana e obras de infraestrutura.

Nesse sentido, sob a pressão das violentas remoções involuntárias, a regularização fundiária é reconhecida como a melhor solução, mas, como coloca Sérgio 
Baierle $^{1}$, deixa-se de questionar as causas e passa-se apenas a administrar as consequências do processo desigual de ocupação do território urbano. Dada como melhor opção, a regularização fundiária vai atuar, com base em novos e flexíveis critérios, no sentido de delimitar um novo limite para aquilo que, agora, pode ser considerado regular.

Considerando os termos da Lei Federal no 11.977 de 2009, com a regulamentação do Programa Minha Casa Minha Vida - PMCMV -, bem como do Programa de Regularização Fundiária para Assentamentos Urbanos Informais, estes dois instrumentos podem ser utilizados de forma complementar para a estruturação da política habitacional no âmbito municipal.

Considero que a política pública passa por transformações desde sua concepção no âmbito federal até sua efetiva realização no âmbito municipal, ao passo que se sobrepõe a uma política habitacional municipal em andamento, promovendo rupturas e reforçando permanências que moldam uma configuração única formada por agentes e ações locais. Assim, a cidade escolhida para a pesquisa empírica é Londrina, no Paraná, onde a implantação dos programas da Lei Federal no 11.977/2009 vem sendo realizada em grande escala. Desse modo, o estudo dos novos programas habitacionais - PMCMV e o Programa de Regularização Fundiária - é relevante para compreender se mudam e como mudam os rumos da política habitacional municipal.

O que apresento é uma outra forma de olhar para a política habitacional, inserindo-a em uma dinâmica do governo dos corpos e da população, contextualizandoa nos processos da política urbana. É claro que esses processos - política urbana, política habitacional, política de saúde, dinâmicas de mercado, etc. - não são independentes, apesar de terem suas dinâmicas próprias. O que proponho neste trabalho é justamente compreender como essas dinâmicas próprias da política habitacional se conectam à circulação de capital que condiciona a política urbana.

\footnotetext{
${ }^{1}$ Apontamento feito na Sessão Livre “Da reforma urbana ao Minha Casa Minha Vida: balanço de 30 anos de lutas e políticas urbanas" (Baierle, 2017).
} 
Se, por um lado, pesquisas já afirmaram os diálogos entre mercado imobiliário e política habitacional em outras ocasiões - como o vetor de crescimento e valorização imobiliária constituído pela implantação dos primeiros conjuntos habitacionais na zona norte de Londrina -, agora busco, nas práticas cotidianas do Estado - aqui corporificado na Cohab-LD e nos Cartórios de Registro de Imóveis -, como esses diálogos se transformaram em mecanismos que constituíram um modo de operar a que chamamos de política habitacional de Londrina.

Portanto, eis a proposta: evidenciar a partir das práticas cotidianas dos trabalhos da Cohab-LD, como é feita a gestão dos ilegalismos urbanos por meio dos programas habitacionais - supostamente - de interesse social. A análise do papel do Estado se dá pelo estudo das práticas do Estado no nível mais imediato do cotidiano.

A análise sobre o exercício do poder sobre as populações nos ajuda a fazer a leitura do conjunto de práticas que dão forma à ação da Cohab-LD na gestão dos ilegalismos urbanos referentes à habitação. Para Foucault, o discurso é uma dimensão fundamental na análise e deve ser interpretado a partir dos enunciados que se formam na constituição do discurso. Não se busca o que não foi dito, mas a partir do pronunciamento, encontrar a lógica do pensamento e das intencionalidades como uma das estratégias de instituição do poder. Por isso, para embasar a análise, recupero os documentos que forneceram as bases diagnósticas que justificam e legitimam as práticas da Cohab-LD na implantação dos programas habitacionais em questão.

\section{Sobre o método da pesquisa}

Não saber o que vai descobrir é, evidentemente, uma verdadeira descoberta ${ }^{2}$.

Antes de definir efetivamente qual seria o recorte da pesquisa no início do programa de doutorado, era meu interesse estudar os instrumentos da legislação

\footnotetext{
${ }^{2}$ Strathern (2014, p.353).
} 
referentes à política pública habitacional. Também tinha como referência o conceito de "direito à cidade", ainda que nesse momento fosse, para mim, um conceito bastante abstrato, mas que de alguma forma representava uma ideia de justiça social na cidade e parecia um caminho para o enfrentamento das condições de desigualdade em que se encontram grandes parcelas da população.

Para a definição do objeto também já estavam colocadas as profundas mudanças - mesmo que com padrões não tão novos - que o Programa Minha Casa Minha Vida vinha provocando nas cidades brasileiras, principalmente nas periferias. Esse processo era evidente em Londrina. Naquele momento [2015] havia sido construído em Londrina um dos maiores empreendimentos do PMCMV, o Residencial Vista Bela. Assim, esse programa se colocava como outra questão fundamental que eu não poderia deixar de considerar na definição do objeto da pesquisa.

Eu tinha ainda fragmentos de questões de pesquisa ${ }^{3}$ decorrentes de experiências no contexto da política habitacional de Londrina, principalmente relacionada ao instrumento das ZEIS. Era possível observar um campo de disputa em torno desse instrumento, e os obstáculos para regulamentação das ZEIS foram determinantes. Entretanto, as pesquisas e constatações respondiam a maior parte das minhas indagações 4 .

Portanto, sem abandonar essas questões, mas olhando para o quadro da política habitacional recente, observei que a mesma Lei que regulamentou o PMCMV também regulamentou o programa de Regularização Fundiária de Interesse Social. Isso pareceu muito relevante tendo em vista que todo o debate sobre a política habitacional no Brasil sempre apresentou a regularização fundiária como a principal reivindicação da população, como uma alternativa ao padrão predominante de produção de habitação

\footnotetext{
${ }^{3}$ Questões formuladas a partir da observação de distorções na implantação e consequente ineficácia do instrumento no caso de Londrina.

${ }^{4}$ As principais questões levantadas foram respondidas pela tese de Caio Santo Amore (2013). Nas conclusões do trabalho, o autor mostra que apesar das ZEIS representarem um importante potencial que possibilita maior justiça social, garantia do direito à moradia adequada, etc., esse instrumento é abordado de maneira superficial no Estatuto da Cidade e, por isso, passa a ser objeto de detalhamento por guias de implementação. Nesse sentido, é construído um forte discurso quanto ao seu potencial e as possibilidades que ele abre, no entanto, segundo o autor, esse potencial não foi, ainda, experimentado na prática.
} 
de interesse social. Procurei então fazer uma primeira aproximação dessa Lei Federal e verifiquei que no seu conteúdo havia novidades em relação ao que foi regulamentado sobre Regularização Fundiária no Brasil até então.

Enfim, busquei saber se em Londrina esse programa também havia sido implementado. De fato, na gestão 2013-2016 foi criado um programa municipal de regularização fundiária e os números de unidades regularizadas, em fase de regularização, e os que seriam regularizados eram expressivos. Então, defini o recorte de pesquisa para uma análise da política habitacional de Londrina após a regulamentação da Lei Federal no 11.977/2009, com interesse maior na implantação do programa de regularização fundiária.

No primeiro momento, me interessava tanto os procedimentos para a implantação desse programa, a escolha das áreas, e as ações associadas à regularização e, também, se o programa considerava a proposta inicial de implantação das ZEIS, com relação à delimitação das áreas e à categorização dos diferentes tipos de estratégias associadas à regularização. Assim, essas interrogações abriram possibilidades de análise sobre o instrumento. Ademais, todas as constatações a respeito do PMCMV mostram que a política habitacional não pode mais ser analisada apenas do ponto de vista da produção de espaço físico, ou como respostas ao déficit habitacional.

Como esse tema trata de um programa em andamento - que estava em andamento naquele momento e ainda está - era necessária uma pesquisa exploratória para coletar o maior número de informações possível a respeito do programa, sem os riscos de pré-estabelecer recortes para a coleta de dados (normalmente realizados por uma revisão bibliográfica inicial) e construir uma visão parcial de pesquisa. Dessa forma, a pesquisa empírica se colocou como a melhor estratégia 5 .

\footnotetext{
${ }^{5}$ A pesquisa empírica tem como característica a adoção da pesquisa de campo como espinha dorsal do trabalho. A partir da pesquisa de campo é que se desdobram as hipóteses e a busca pelas respostas. Enquanto o campo é o ponto de partida, a teoria é o ponto de chegada (Rizek, 2013). Em uma pesquisa tradicional em que se começa pela revisão bibliográfica e pela sistematização das teorias que existem sobre aquele objeto, são definidos recortes prévios de perspectivas que se pode construir, e a partir disso realizada a investigação sobre determinado fenômeno. Esse recorte determina a pesquisa de campo e a coleta de dados. No meu caso, como se conhece muito pouco sobre o objeto, qualquer recorte poderia
} 
Além dos dados estatísticos, das coletas objetivas e análise de conteúdo da legislação, era necessária uma investigação de perto e de dentro ${ }^{6}$ do programa, um dos objetivos da pesquisa etnográfica. Nesse sentido, a pesquisa de caráter etnográfico apresentou estratégias e instrumentos que possibilitariam aumentar a amplitude de pesquisa ${ }^{7}$ para realmente compreender o papel desse programa na política habitacional de Londrina; quais caminhos se abrem e quais se fecham.

Para além da pesquisa empírica, portanto, a ideia de que o campo deveria ser realizado a partir de incursões de caráter etnográfico, tendo em vista que a pesquisa etnográfica pode ser "um caminho fértil para compreender a produção (...) das dimensões urbanas e seus sentidos" ${ }^{\prime}$, busquei compreender as dimensões constituídas a partir do fazer, executar dos programas habitacionais.

Segundo Rizek (2013, p.19), a pesquisa etnográfica permite uma investigação que penetre nas dimensões desse fazer, do conjunto das práticas e das relações que se estabelecem, de modo a revelar seus segredos. Assim, é possível "interpretar as representações" a partir dos discursos, das disputas, dos consensos e dissensos, sem perder a clareza de quais são as dimensões estética e simbólica e como elas estão vinculadas e presentes nessas práticas.

O diário de campo e as entrevistas foram instrumentos fundamentais para possibilitar a recriação do campo nesta etapa de escrita da tese. Como alertou Rizek, só

\footnotetext{
comprometer a compreensão do programa. Não seria possível construir uma visão global sobre o programa se não tivesse começado por uma pesquisa de campo de caráter exploratório.

${ }^{6}$ De perto e de dentro é uma expressão colocada por Magnani (2002) sobre o uso do método etnográfico nas pesquisas sobre a cidade, em oposição ao olhar distante do pesquisador. De perto e de dentro significa conhecer de perto e interpretar os sujeitos e as práticas, trazendo a densidade do "concreto vivido" para o arranjo da pesquisa.

${ }^{7}$ Com relação à coleta de dados na pesquisa etnográfica, o grande desafio está na "definição de que amplitude de informação se pode desejar" e, ainda, chegar. Como o investigador não tem conhecimento prévio de quais serão os "fatores relevantes" para a análise, nem mesmo como será realizada a análise do material que será colhido, deve buscar a maior amplitude de dados possível como uma ação de responsabilidade a respeito do conteúdo que produzirá. Esse cuidado é enfatizado por Strathern (2014) dizendo que, normalmente, "o que deve ser levado em conta é o que foi negligenciado". Para ela esse esforço é questão de método, pois o etnógrafo colhe dados que não são, ainda, informação. No momento da coleta de dados quem têm o controle das informações são os entrevistados (Strathern, 2014, p. 348/349).

${ }^{8}$ Rizek (2013, p.20).
} 
se chega ao texto a partir desse retorno ao trabalho de campo ${ }^{9}$. Com base nos preceitos da pesquisa etnográfica, o campo foi o ponto de partida do trabalho, enquanto as "dimensões conceituais e teóricas" foram o "ponto de chegada"10.

Usar como base as noções da pesquisa etnográfica demandou uma reflexão sobre o papel da pesquisa e do pesquisador na construção de teorias. Deixar-se levar pelo campo e realmente descobrir questões relevantes sobre os processos investigados que foram ou não considerados inicialmente como hipótese, esclareceram para mim uma diferenciação importante sobre a atividade de pesquisa. Por um lado, a pesquisa que busca uma resposta para uma pergunta específica, e que nesse processo de investigação abre mão (a partir dos recortes e hipóteses pré-estabelecidas) de outras descobertas. De outro lado, a pesquisa que investiga um fenômeno sem recortar ou préconceber conceitos e práticas relevantes, que a partir da presença e observação no campo revela aquilo que está além das representações e da estética, aquilo que só pode ser compreendido com a interpretação das falas e das práticas inseridas (e não recortadas) daquele contexto completo (e complexo). O trabalho de pesquisa e construção de uma tese se revelou para mim, dessa forma, muito mais como uma narrativa que visa elucidar (e emancipar) "as informações, sentidos e práticas que se pôde observar"11 e assim, compreender aquele fenômeno, do que de apontar uma resposta.

Minha pesquisa de campo teve início com uma pesquisa exploratória no setor de regularização fundiária da Cohab-LD, onde permaneci por três meses acompanhando os trabalhos realizados pelos profissionais. Para realizar essa incursão, tomei como base referências sobre a pesquisa etnográfica para que essa experiência de campo ganhasse amplitude suficiente para desenvolver uma análise substancial. A partir desta primeira incursão em campo, a pesquisa foi encaminhada na medida em que os "achados de pesquisa" se revelavam e possibilitavam a construção das hipóteses secundárias que

\footnotetext{
${ }^{9}$ Rizek (2013, p.23).

${ }^{10}$ Rizek (2013, p.24).

${ }^{11}$ Rizek (2013, p.20).
} 
direcionaram a investigação. Portanto, a delimitação do campo foi construída a partir dos desdobramentos que o próprio campo revelou.

Durante o período que fiquei no setor de regularização fundiária, acompanhei os trabalhos diários, o atendimento das famílias, visitas à campo, o trabalho do setor jurídico e dos técnicos, todos os procedimentos burocráticos, jurídicos, e de intervenção no espaço. Procurei identificar os casos mais relevantes e as dificuldades que ainda existem. Nas entrevistas ${ }^{12}$, procurei alcançar a maior diversidade possível de atores, incluindo moradores das áreas atendidas pelo programa.

Nesta primeira etapa, algumas questões foram fundamentais no direcionamento da pesquisa. Em primeiro lugar, observei que grande parte dos processos de regularização ocorreu após remoções e, portanto, se tratava de assentamentos e conjuntos habitacionais promovidos pela própria Cohab-LD e que nunca foram regularizados e, assim, este processo se referia mais a um procedimento de registro do que relacionados à urbanização de favelas. Outro fator, é que enquanto a regularização fundiária é vista de modo geral como um programa mais barato do que a construção de novas moradias, os custos da regularização são calculados com base nos terrenos que são disponibilizados e, por isso, o programa é encarado pelo setor financeiro da CohabLD como "descapitalização". A existência de um consenso sobre a impossibilidade de regularização em áreas de fundo de vale (faixa sanitária e APP) corresponde a uma generalização em relação a esses casos que são classificados homogeneamente como áreas de risco, porém é onde se localiza o maior número de ocupações irregulares e uma

\footnotetext{
${ }^{12}$ Como alerta Rizek (1999), as entrevistas não podem ser utilizadas como dados sem submetê-las a um processo de interpretação. Nos confrontos entre as entrevistas são reveladas as diferentes visões inclusive divergentes - sobre a prática da Cohab-LD e como essas visões encontram-se hierarquizadas nos processos decisórios. Somente com esse confronto entre as entrevistas realizadas nos diferentes setores é que se revelam as intenções e o caráter tecnocrata da implantação do programa. Essas entrevistas revelaram um conjunto de questões de pesquisa que, no primeiro momento, não teriam sido previstas. As entrevistas permitiram compreender a diversidade entre os atores dentro da mesma instituição: o uso do termo INVASÃO ou OCUPAÇÃO pelos diferentes profissionais e pessoas; o discurso fundado na "função social da propriedade" e no direito à moradia, mas profundamente preconceituoso e tecnocrata dos engenheiros e arquitetos; a fala blindada dos representantes da Cohab-LD quando negociam e dialogam com os movimentos insurgentes; a construção do discurso do "risco", etc. Ou seja, "as falas em confronto, o que apontam e sobre o que silenciam ao descreverem o que aparentemente se apresenta aos olhos dos pesquisadores (...) podem permitir detectar conflitos entre mundos sensíveis diversos entre si, entre formas de percepção e nomeação, entre significações diversas" (Rizek, 1999, p.330).
} 
grande parte delas encontra-se consolidada. Além disso, foram atendidos no programa apenas os assentamentos que não demandavam urbanização. Ainda, todas as áreas particulares ocupadas foram previstas pelo programa como remoção (antes ou depois de completar 5 anos).

Portanto, nesse momento da pesquisa me deparei com a seguinte constatação: a regularização fundiária não aparecia como uma alternativa oposta à remoção, mas sim como parte de um processo chamado de desfavelamento. Por isso, foi necessário levantar dados mais precisos sobre as remoções que ocorreram no momento de implantação do PMCMV. Para isso, realizei uma pesquisa documental no Setor Social na Cohab-LD, onde permaneci por mais seis meses, levantando a documentação, entrevistando funcionários e acompanhando os trabalhos do Setor. Os números foram surpreendentes, mas também a aceitação e o baixo índice de resistência às remoções promovidas. Por isso, iniciei um estudo de caráter genealógico ${ }^{13} \mathrm{em}$ documentos oficiais da Cohab-LD e reportagens sobre o desfavelamento procurando compreender como se consolida como uma prática constante da Cohab-LD.

Durante o período da pesquisa [com início em 2016] a Comissão de Direito Imobiliário e Urbanístico da OAB de Londrina promoveu três Colóquios sobre Direito Imobiliário em que foram discutidas matérias sobre a regularização fundiária. Em 2016, ocorreu o 2ํㅡ Colóquio de Direito Imobiliário e Urbanístico. No primeiro momento, o que me chamou a atenção era que a Cohab-LD participaria no eixo de discussão sobre regularização fundiária regulamentada pela Lei Federal no 11.977/2009.

A Cohab-LD participou com uma intervenção sobre os processos de regularização fundiária em andamento, pois um dos temas do Colóquio era a Regularização Fundiária regulamentada na Lei Federal no 11.977/2009. Participei desse Colóquio e outras questões apareceram. Primeiro, o Colóquio trouxe uma visão do campo do direito imobiliário sobre a regularização que extrapolava a dimensão do direito à moradia e da

\footnotetext{
${ }^{13}$ Foucault (1998, p.07) chama de genealogia "uma forma de história que dê conta da constituição dos saberes, dos discursos, dos domínios do objeto, etc. sem ter que se referir a um sujeito, seja ele transcendente com relação ao campo de acontecimentos, seja perseguindo sua identidade vazia ao longo da história."
} 
política habitacional. Outro aspecto que me chamou a atenção foi que os principais interlocutores sobre a Lei e a Regularização eram os cartorários, que traziam uma dimensão econômica importante sobre a regularização fundiária realizada em larga escala, possibilitada pela Lei Federal no 11.977/2009. Participei de três edições do Colóquio e, em cada uma delas, novas questões foram formuladas. Passei a frequentar outros eventos, como os organizados pela OAB Curitiba e pelo Consórcio dos Municípios do Alto Tietê, e em todos eles advogados e cartorários eram os principais interlocutores do debate sobre a regularização fundiária.

Observar a abordagem da regularização fundiária no campo jurídico a partir desses interlocutores trouxe uma outra questão para a pesquisa: o protagonismo dos cartórios de registro de imóveis e a inserção da regularização fundiária em um conjunto de medidas que revisam as normativas referentes aos procedimentos imobiliários no Brasil. Nesse sentido, novas estratégias foram adotadas, como entrevistas com cartorários, compreender o procedimento da regularização fundiária em um cartório local e uma pesquisa documental sobre as mudanças recentes na legislação sobre os procedimentos imobiliários no Brasil.

Segundo Strathern (2014, p.352), o "momento etnográfico" corresponde à junção dos dois campos da pesquisa: o campo do momento da incursão e o momento da escrita. Para ela, o principal desafio do campo é que sua realização deve ter em mente o momento da escrita, que deve ser uma "recriação imaginativa" dos efeitos identificados durante a pesquisa de campo. Para ela, portanto, a escrita cria esse segundo campo, a partir de "uma relação que junta o que é entendido (analisado no momento da observação) à necessidade de entender (o que é observado no momento da análise). Ela defende esse ponto de vista a partir da noção de "Holismo", que considera que "toda informação pode ser relevante para uma descrição mais ampla" que está sempre "esperando futura elucidação".

Assim, a tese foi construída com base nos dados selecionados sob a lógica dos "acontecimentos capazes de explicar"14 os fenômenos observados.

\footnotetext{
${ }^{14}$ Bourdieu (2014, p. 49).
} 
Quando a informação é colhida não se sabe, portanto, quais aspectos se mostrarão significativos para a análise, pois essa "significância" é revelada no momento da escrita, na "descrição feita depois do evento". Assim, o campo deve estar "aberto" aos procedimentos posteriores - a escrita. No momento da coleta o pesquisador ainda tem pouco conhecimento sobre as conexões. Nesse sentido, a "imersão" tem a função de valorizar as relações em si mesmas, simplesmente reconhecendo que elas têm valor, e que a informação resultante da análise dessas relações é residual em relação à coleta e, na maior parte das vezes, ela não é previamente conhecida.

A perspectiva da pesquisa é organizada a partir do pondo de vista do pesquisador, "afinal, o que concebemos como objeto de estudo deve ser mediado pelo que fazemos do nosso conhecimento no mundo". Por isso, cada perspectiva é um momento radical e individual ${ }^{15}$.

Como tenho formação em arquitetura e urbanismo, o estudo de caráter genealógico foi determinante para que eu desconstruísse ideias e discursos préconcebidos. Foi surpreendente, para mim, verificar a reprodução de determinados discursos e verdades em documentos que participei da elaboração durante minha atuação profissional.

Em pesquisa anterior ficou claro que o resultado da produção da Cohab-LD é qualitativamente inferior ao resultado obtido pelas cooperativas de construção. 0 questionamento do papel da arquitetura, da concepção dos projetos, na efetivação da política habitacional, a influência da arquitetura do bairro nas formas de sociabilidade eram questões presentes. A desmobilização em torno da questão da moradia e a queda na qualidade ao longo do tempo também eram perceptíveis. Por trás dessas questões já estava uma questão central: qual o papel da Cohab-LD na construção da política habitacional de Londrina, sendo ela o único órgão do Estado responsável pela problemática habitacional da cidade de Londrina? Quais os demais agentes envolvidos nesse processo?

${ }^{15}$ Strathern (2014, p.393). 
Assim, também foi necessário repensar o conteúdo e o papel da legislação. Conhecer as práticas de perto e de dentro, me permitiu desconstruir a visão genérica do Estado e das disputas em torno das decisões que condicionam as políticas urbanas. Assim, busquei um referencial que me possibilitasse construir uma perspectiva de pesquisa que recolocasse o Estado enquanto agente e a legislação como instrumento no exercício do poder.

Nesse sentido, argumento que enquanto as formas alternativas ao mercado formal de acesso à moradia não forem reconhecidas como legítimas, em que pese o direito à moradia e a função social da propriedade reconhecidos na Constituição, continuarão sendo enquadradas como irregulares, tratadas como exceção e dependentes de políticas paliativas de regularização.

Se há entendimento que a legislação define critérios para deliberar o que é formal, como consequência o que não se encaixa nos parâmetros é automaticamente entendido como informal. Isso pode acontecer no âmbito urbanístico e no âmbito fundiário. No caso de Londrina, a legislação urbanística veio legitimar a morfologia do parcelamento do solo realizado pela Companhia colonizadora responsável pelo empreendimento que deu origem às cidades do norte "novo" do Paraná - Companhia de Terras Norte do Paraná - e, assim, as ocupações que emergem nas margens do empreendimento que deu origem à cidade estavam irregulares perante a legislação urbana e a propriedade da terra.

As soluções para a informalidade habitacional pela regularização fundiária foram analisadas a partir dessa premissa. Concluo este capítulo com uma consideração de Foucault acerca da metodologia que procurei seguir na construção desta tese:

Recapitulando as cinco precauções metodológicas: em vez de orientar a pesquisa sobre o poder no sentido do edifício jurídico da soberania, dos aparelhos de Estado e das ideologias que o acompanham, deve-se orientá-la para a dominação, os operadores materiais, as formas de 
sujeição, os usos e as conexões da sujeição pelos sistemas locais e os dispositivos estratégicos ${ }^{16}$.

\section{Sobre o tema da pesquisa}

O Programa Minha Casa Minha Vida - PMCMV - foi profundamente analisado por pesquisas que revelaram a reconfiguração dos agentes da política habitacional, as relações com o mercado financeiro, os meandros das negociações locais e seus efeitos territoriais. Muitas dessas questões podem ser vistas no caso de Londrina. Por outro lado, o Programa de Regularização Fundiária não foi analisado com a mesma profundidade.

Algumas pesquisas - algumas delas com recursos federais do Programa Papel Passado - sistematizaram as condições institucionais e leis municipais que deram (ou não) as condições para a criação dos programas nos contextos municipais. Outras pesquisas, principalmente do campo jurídico, analisaram os novos instrumentos de regularização criados pela Lei Federal. A polêmica aprovação da Lei Federal no 13.465 em 2017, no contexto político controverso após o golpe de 2016, suscitou muitos debates e conteúdo que questionam sua constitucionalidade e os possíveis efeitos ambientais e sociais decorrentes da sua implementação. Ainda, algumas pesquisas indicam que a implantação do PMCMV promoveu remoções involuntárias de assentamentos informais.

Nesse sentido, é um fato relevante que o conteúdo da Lei Federal no 11.977/2009 aborde a criação desses dois programas habitacionais que podem funcionar como estratégia complementar na construção da política habitacional municipal: a produção de novas moradias e a regularização fundiária de assentamentos urbanos, sobretudo em um contexto político nacional peculiar em que avançavam algumas frentes de esquerda.

\footnotetext{
${ }^{16}$ Foucault (1998, p.104).
} 
Após a aprovação do Estatuto da Cidade, a eleição de um partido de esquerda e a promessa de construção de uma política habitacional dava indícios de efetivação com a criação do Ministério das Cidades, da Secretaria de Habitação, do Departamento de Assuntos Fundiários e com a nomeação de profissionais historicamente ligados ao Movimento pela Reforma Urbana.

Entretanto, a partir das evidências coletadas nos últimos anos, Rolnik (2015) destaca a inter-relação entre processos de financeirização do solo urbano e da moradia aos problemas habitacionais recentes - grande número de despejos e aumento no número de desabrigados - assistidos por todo o mundo. Nesse contexto, Rolnik (2015, p.26) enfatiza o papel fundamental do complexo imobiliário-financeiro para a questão habitacional nas cidades e que se trata de "um longo processo de desconstrução da habitação como um bem social e sua transmutação em mercadoria e ativo financeiro".

A ascensão do circuito financeiro como estruturador da economia capitalista destaca o capital fictício e a extração de renda como os principais geradores de riqueza. Como base dessa lógica, temos a inclusão de um maior número possível de consumidores por meio de diferentes estratégias de financiamento habitacional, além de diferentes sistemas de empréstimo ${ }^{17}$.

Para isso, contou-se com a disseminação e consolidação da ideologia da casa própria e a "inclusão de consumidores de média e baixa rendas com ampliações de sistemas de crédito $^{18}$. Esse pensamento foi disseminado pelas principais agências multilaterais e é adotado pelos governos em todas as partes do mundo ${ }^{19}$. A partida está na orientação do Banco Mundial para a formulação de novas políticas, o que promoveu aumento na realização do financiamento habitacional. Rolnik (2015) ainda destaca que a ação estatal é fundamental na transmutação da moradia de um bem social em mercadoria e ativo financeiro.

Dessa forma, é enfática a importância que ganha a propriedade privada para possibilitar o desenrolar desse processo idealizado pelo Banco Mundial. Enfim, Rolnik

\footnotetext{
17 Rolnik (2015).

${ }^{18}$ Rolnik (2015, p.26).

${ }^{19}$ Rolnik (2015); Arantes (2004); Maranhão (2009).
} 
(2015) aponta três modelos de financeirização da moradia: o sistema baseado em hipotecas - menos disseminado no Brasil -, sistemas baseados em subsídios governamentais associados a créditos financeiros para compra de habitações produzidas via mercado - modelo implantado no PMCMV -, e sistemas de microfinanciamento.

Sobre esse assunto, Gilbert (2004) aponta um importante pressuposto para a pesquisa quanto ao interesse das agências multilaterais nos processos de regularização fundiária dos países em desenvolvimento, para os quais têm financiado os projetos e pressionado os governos locais para que a população atendida use a habitação regularizada como garantia para contrair empréstimos. Ainda, para o autor, o verdadeiro motivo para a implantação da política de regularização tem sido o ganho eleitoral. Os governos se beneficiam com a distribuição dos títulos por ficarem bem vistos pela população. $O$ autor também afirma que é uma campanha barata, tendo em vista que, na maioria das vezes, os beneficiários são cobrados pelos serviços e, ainda, começam a pagar impostos.

Essa hipótese baseia-se nas proposições de Hernando De Soto após as orientações do Banco Mundial quanto à monetarização da população de baixa renda ${ }^{20}$. Calderón (2009) contesta De Soto afirmando que após a distribuição de títulos no Peru, os ganhos não foram compatíveis com as expectativas. Raquel Rolnik também cita esse pressuposto, mas aponta a falta de estudos que comprovem tais afirmações.

A regularização fundiária instituída pela Lei Federal no 11.977/2009 emerge, portanto, desse contexto, sendo associada por diferentes pesquisas ao circuito de fluxo de capital como estratégia de inclusão da população de baixa renda. Foi, por outro lado, bastante celebrada no contexto nacional. Historicamente, a política de regularização fundiária tem sido objeto de reivindicação do Movimento pela Reforma Urbana em oposição às remoções forçadas da população de assentamentos informais para conjuntos habitacionais periféricos produzidos pelo Estado. Apesar de conquistas do movimento no campo legislativo, com a abordagem da função social da propriedade na

\footnotetext{
${ }^{20}$ Fernandes (2001).
} 
Constituição Federal, a revisão da lei de parcelamento do solo e a criação do instrumento das Zonas Especiais de Interesse Social, essa é a primeira vez que a legislação cria mecanismos efetivos que respaldam os municípios para a execução da regularização de interesse social em grande escala.

As soluções estatais apresentadas às ocupações irregulares em um primeiro momento consideravam as formas improvisadas de moradia existentes, principalmente em favelas e cortiços, como problemas que deveriam ser solucionados em definitivo com a remoção total para outros locais ${ }^{21}$. Nesse sentido, as ações autoritárias que visaram resolver essa questão promoveram numerosas remoções forçadas dessa população para conjuntos habitacionais periféricos, sem infraestrutura e de baixa qualidade construtiva, financiados pelo Banco Nacional da Habitação, e ainda provocaram o deslocamento de uma parcela da população para assentamentos precários periféricos 22 .

Com base nas divergências entre a produção e as reais demandas habitacionais, o Movimento pela Reforma Urbana lutou pela não remoção e a regularização fundiária e urbanística dos assentamentos informais precários. Desde o fim da ditadura militar e consequente esgotamento desse modelo de produção de habitação de interesse social, - Movimento pela Reforma Urbana teve duas importantes conquistas no campo jurídico: a inclusão dos artigos 182 e 183 na Constituição Federal, tratando principalmente da função social da propriedade, da usucapião urbana e da obrigatoriedade do Plano Diretor; e a aprovação do Estatuto da Cidade - Lei Federal no 10.257/2001 - que regulamenta os artigos 182 e 183 da Constituição e institui instrumentos de caráter antiespeculativo para operacionalizar a ação municipal nesse sentido.

A ênfase de justiça social contida nos artigos encontra-se principalmente no § 2 은 do artigo 182, que conceitua a função social da propriedade, e também no $\S 4$ que faculta ao poder público exigir dos proprietários que promovam o adequado aproveitamento do imóvel. Nesse artigo, apesar da crítica quanto ao caráter

${ }^{21}$ Serran (1976) Apud Santo Amore (2013).

22 Santo Amore (2015). 
tecnocrático que vincula todas as exigências ao Plano Diretor ${ }^{23}$, destacam-se os princípios antiespeculativos do texto. Essa questão é fundamental para a discussão sobre a regulação do mercado imobiliário, já que este obedece a uma lógica especulativa utilizada como mecanismo para promover a oscilação dos preços dos imóveis ${ }^{24}$. No artigo 183 foi regulamentada a usucapião urbana, que também apresenta um princípio antiespeculativo e garante o direito de posse para aquele que utiliza a terra para fins habitacionais.

O "marco conceitual" trazido pela Constituição Federal e a aprovação do Estatuto da Cidade são fatos considerados fundamentais por Fernandes ${ }^{25}$ quanto à discussão sobre a reforma do poder judiciário. Segundo o autor, a proposta progressista de reforma reconhece os direitos coletivos em oposição à visão do liberalismo jurídico que reconhece apenas direitos individuais ${ }^{26}$.

É no que toca à propriedade imobiliária, mais especificamente a urbana, que nós nem reformamos o legalismo liberal clássico do Código Civil. Não há como se falar em neoliberalismo nesse contexto, quando nós ainda vivemos sob a égide do imaginário jurídico típico do liberalismo, com toda essa ênfase na propriedade absolutista, individualizada e com o espaço de controle pelo poder público ainda muito limitado! (...) No que toca à noção de propriedade, ao longo de setenta anos, da década de 30 para cá, aos trancos e barrancos, o que nós temos visto no Brasil é o embate de dois paradigmas: esse do legalismo liberal do Código Civil e o da função social da propriedade, que é resgatado na Constituição de 1934. E que vai gerar as leis urbanísticas, as leis ambientais, que vão lutando por hegemonia,

${ }^{23}$ Santo Amore (2013, p.44) afirma que as referências ao Plano Diretor não estavam previstas nos documentos da emenda popular, e que foram incluídas com base em uma visão tecnocrata.

${ }^{24}$ A formação do preço dos imóveis tem como uma das bases de cálculo o potencial de ganho com aluguéis que varia de acordo com a infraestrutura e as normas de uso e de ocupação do solo, as possibilidades de renovação da área, entre outros fatores.

${ }^{25}$ Fernandes (2001, p.23).

${ }^{26} \mathrm{Em}$ consulta a dois advogados sobre essa questão, as colocações de ambos sobre a prática do direito evidenciam esse embate. Eles esclarecem que para a sentença judicial prevalece a lei mais específica sobre o assunto. No caso de embates fundiários, a Constituição Federal traz apenas princípios gerais, enquanto a abordagem do Código Civil sobre a propriedade privada da terra é mais específica e, por isso, pode prevalecer na decisão judicial em detrimento da abordagem constitucional. Além disso, ressaltam que o tratamento diferenciado sobre o mesmo assunto por leis diferentes pode configurar "conflito aparente", em que o juiz analisará o caso específico adotando a lei mais específica sobre o assunto. 
sobretudo em um contexto em que o Estado não promove a reforma fundiária ${ }^{27}$.

Fernandes (2001) completa ainda,

\begin{abstract}
O golpe de 1964 quebra esse processo, que só é recuperado em 1979, com a Lei do Parcelamento do Solo, isso tudo desembocando na Constituição de 1988, com a proposta da função social da propriedade e da cidade, e com o Estatuto da Cidade consolidando tudo isso. A "americanização" aqui significa voltar para trás, voltar lá para o paradigma da propriedade individualista, na qual o poder do Estado de determinar o aproveitamento econômico da propriedade quase que inexiste; em que o direito de usar, gozar e dispor da propriedade, que é a fórmula clássica do legalismo liberal, é determinado pelo próprio interesse do indivíduo, sem levar em conta os outros interesses sociais e ambientais. (...) Há uma recusa desse movimento histórico brasileiro de construção de um novo olhar. Porque, na base disso, está uma outra visão do que é a terra na sociedade, do que é a terra na própria economia ${ }^{28}$.
\end{abstract}

Segundo Azuela (1998) a doutrina da função social da propriedade foi instituída pelo jurista francês Leon Duguit. Com base na II Conferência "Who Owns America", Azuela $(1998$, p.78) traça um panorama sobre as ideias predominantes na América com relação à terra. O autor destaca que nos EUA prevalece a importância dos direitos de propriedade, fato que embasa a colocação de Edésio Fernandes (2001) quanto à americanização do direito brasileiro. Na Conferência defendeu-se a ideia de que é necessário ampliar a noção de propriedade para dar conta das novas demandas sociais relativas à terra urbana.

O Código Civil de 1916 sofreu muitas influências do esboço de Teixeira de Freitas, antes responsável pela tarefa de organizar a legislação civil brasileira. A participação de Teixeira de Freitas deu-se logo após a institucionalização da Lei de Terras de 1850, que correspondeu ao marco da individualização da propriedade brasileira. Os traços da Lei de Terras responderam aos anseios de preservação da propriedade privada no Brasil,

\footnotetext{
${ }^{27}$ Fernandes (2001, p.30).
}

${ }^{28}$ Fernandes (2001, p.31). 
decorrentes da discussão sobre abolição da escravidão que já pairava pela Europa. Como no Brasil a economia (e consequentemente, o poder) estava fundamentalmente pautada na produção agrícola pelo trabalho escravo, as garantias da Lei de Terras vieram no sentido de preservar a propriedade da terra no caso de questionamento da validade da propriedade do escravo. O sistema de registro também se aprimorou nessa época ${ }^{29}$.

Nesse sentido, após a abolição da escravidão no Brasil em 1888, houve uma "transformação na mentalidade econômica" no país, com ascendente valorização econômica dos bens imóveis ${ }^{30}$. É, portanto, nesse contexto de valorização e preservação da propriedade imobiliária em que é escrito o Código Civil brasileiro. Segundo Silva, o texto original continha um capítulo quanto aos "deveres do proprietário" que trazia a noção de função social da propriedade, mas este foi retirado no texto no momento da aprovação do código. O autor ressalta que a revisão do código em 2002 mantém o fundamento na busca por segurança nas apropriações imobiliárias da elite proprietária.

Em que pese essa distinção de abordagens, apesar da importância do texto da Constituição, foi necessário regulamentar o conteúdo dos artigos 182 e 183 no Estatuto da Cidade, criando instrumentos que garantem a operacionalização dessas ações pelo município $^{31}$. No que se refere especificamente ao direito à moradia, o Estatuto institui as Zonas Especiais de Interesse Social - ZEIS -, porém de forma pouco detalhada. Segundo o Guia para Implementação do Estatuto ${ }^{32}$, o instrumento das ZEIS deve ser utilizado para demarcar áreas em que se visa à regularização fundiária de assentamentos informais e em áreas vazias bem localizadas e dotadas de infraestrutura em que se pretende produzir habitação de interesse social. Além disso, as zonas especiais recebem esse nome por ser uma categoria de zoneamento demarcada em áreas de assentamentos irregulares ou em áreas vazias em que, reconhecendo as características da ocupação nessas áreas e os limites quanto à urbanização, ficam

\footnotetext{
${ }^{29}$ Silva (2014).

30 Silva (2014, p.67).

${ }^{31}$ Santo amore (2013).

${ }^{32}$ Brasil (2002).
} 
permitidos parâmetros legais de ocupação mais flexíveis do que aqueles exigidos nas leis de zoneamento convencionais.

\section{Sobre o objeto da pesquisa}

A implantação desses dois programas em Londrina aconteceu em duas etapas: as negociações do PMCMV começaram em 2009 e o primeiro conjunto habitacional foi entregue em 2011, e o programa de Regularização Fundiária teve início em 2013.

$\mathrm{Na}$ ausência da concepção de uma política habitacional para Londrina, desde a criação da Cohab-LD, programas habitacionais foram concebidos e executados, em grande medida, respondendo a interesses políticos de candidatos e partidos que têm uma concentração maior de votos na periferia da cidade. Neste sentido, a arquitetura dos programas, nesses numerosos casos, refletiu esses interesses priorizando a quantidade em detrimento da qualidade e, sobretudo, reforçou os padrões de segregação socioespacial, respeitando os interesses do mercado imobiliário.

Eis aqui uma questão que parece central na reflexão sobre o papel da Cohab-LD na concepção da política habitacional: a relação entre a Companhia e o mercado imobiliário.

Outras pesquisas ${ }^{33}$ mostraram que os numerosos conjuntos habitacionais implantados na zona norte de Londrina foram âncoras na valorização dos terrenos do grande vazio urbano deixado entre a malha urbana consolidada e os conjuntos habitacionais. Polêmicas em compras de terrenos pela Cohab-LD com privilégios para os proprietários particulares também são evidências da existência de uma relação.

Com base nos inúmeros estudos sobre a produção da Cohab-LD, é possível verificar que, apesar de uma produção numerosa de moradias - sempre dependente de recursos federais -, outros programas relacionados à urbanização de áreas precárias e

\footnotetext{
${ }^{33}$ Fresca e Oliveira (2005), Martins (2007), Cordeiro (2015).
} 
regularização fundiária não tiveram o mesmo protagonismo da produção. No entanto, esses outros programas ainda não foram investigados em conjunto.

A necessidade de compreender com profundidade os outros programas é condição para compreender o papel da Cohab-LD na construção de uma política habitacional, já que esta não se faz apenas da produção de loteamentos e conjuntos habitacionais de interesse social, e nem apenas de uma sequência difusa de programas criados sem um objetivo comum.

Durante a década de 2000, novos programas habitacionais foram realizados envolvendo agentes e recursos que, até então, não eram vistos em Londrina. 0 financiamento de programas Habitacionais pelo BID - Banco Interamericano de Desenvolvimento - envolveu entidades sem fins lucrativos e prefeitura municipal na construção do primeiro diagnóstico habitacional sistematizado que se tornou a base para os programas habitacionais subsequentes.

Nessa fase, a prática do desfavelamento volta à tona com base no discurso da preservação ambiental, mas associado à produção de unidades habitacionais construídas em pequeno número, direcionadas à população removida, em áreas próximas aos locais de origem. Historicamente, as disputas em torno da localização dos pobres na cidade estão no centro da reflexão sobre as políticas habitacionais. A ocupação de vazios urbanos e a manutenção das redes de sociabilidade construídas nos locais de origem fazem parte das reivindicações que pautaram a construção da Lei do Estatuto da Cidade. Na continuação desse processo, a proposta de elaboração de um Plano de ZEIS nesse período parecia remeter à construção efetiva de uma política habitacional para Londrina.

Na contramão, como visto em outros locais, ocorreu em 2009 a negociação do PMCMV, que resultou na construção de conjuntos habitacionais em terrenos grandes e periféricos para os quais foi adotado o critério de remoção de famílias residentes em ocupações irregulares, porém diferentemente nos programas anteriores, promovendo longos deslocamentos para conjuntos completamente desprovidos de infraestrutura. $\mathrm{O}$ maior conjunto habitacional construído pelo programa foi o Residencial Vista Bela, 
localizado no limite da malha urbana no extremo oeste da zona norte da cidade. Para esse conjunto, foram removidas famílias residentes em ocupações irregulares de diferentes regiões da cidade, rompendo com os princípios de territorialidade.

Ao mesmo tempo, com base na Lei Federal no 11.977/2009, também foi esboçado o Programa de Regularização Fundiária, até então, inédito em Londrina-PR. Os números divulgados no início do programa eram expressivos: 7.379 famílias atendidas. Nesse sentido, um primeiro recorte de investigação foi estabelecido: o estudo do Programa de Regularização Fundiária de interesse social realizado em Londrina.

\section{Estrutura da tese}

Pretendo mostrar que os programas habitacionais - da forma como estão articulados entre si e à constituição de discursos e leis que operam como legitimadores das práticas - configuram um dispositivo de gestão dos ilegalismos urbanos. Assim, para a escrita e estrutura da tese, procurei responder à definição de Foucault (1998) sobre a constituição de um dispositivo, que corresponde à rede que se forma entre um conjunto de elementos heterogêneos como práticas, discursos, enunciados científicos, leis, verdades construídas e instituições.

Desse modo, a tese encontra-se estruturada em quatro partes, e cada uma dessas partes está subdividida em capítulos, conforme a descrição que segue:

A Parte I corresponde à caracterização da instituição que é objeto da análise, a Cohab-LD. Esta parte tem uma função introdutória, em que faço a contextualização do objeto da pesquisa apresentando as informações da singularidade da cidade de Londrina e da atuação da Cohab-LD que considero fundamentais para a compreensão da análise.

No Capítulo 1, procuro explicitar como a fundação de Londrina no contexto do empreendimento privado inglês, que deu origem à rede de cidades que compõem o Norte do Paraná, possibilitou a consolidação de um mercado imobiliário restrito e especulativo na área urbana de Londrina e provocou o desenvolvimento precoce do 
setor terciário. Esses fatores, associados às origens da industrialização e à migração de trabalhadores pobres do campo, levaram à formação de assentamentos precários como a única solução de moradia para os pobres na cidade.

No Capítulo 2, abordo a caracterização da Cohab-LD enquanto instituição, evidenciando o fato de ser uma empresa de capital misto do ramo imobiliário que tem como finalidade a comercialização de terrenos e unidades habitacionais para um público de rendas mais baixas. Recuperando as características de produção da Cohab-LD nos diferentes perfis de gestões municipais, argumento que a habitação social é convertida em mercadoria política em um processo de negociações eleitorais, que muitas vezes extrapolam as fronteiras da legalidade.

A parte II trata dos discursos, leis e enunciados responsáveis pela construção de verdades que operam no dispositivo. Nesta parte o foco da análise é a construção dos discursos que conferem legitimidade às práticas.

No Capítulo 3 proponho um debate acerca da dicotomia formal/informal presente nos discursos e em enunciados científicos que historicamente embasaram as propostas de remoções de favelas. No debate, apresento argumentos de autores que mostram que esta dicotomia é um falso problema, e que essa fronteira que separa a informalidade da legalidade é fluida e mutante e está constantemente em disputa.

No Capítulo 4 procuro mostrar como o desfavelamento está posto como uma verdade instituída em Londrina, legitimado por discursos construídos em documentos oficiais e reportagens e por leis que moldam a noção de legalidade a partir do padrão burguês de apropriação do espaço urbano. Nesta discussão, entram em evidência os diagnósticos da precariedade habitacional produzidos por diferentes entidades (com ou sem fins lucrativos) que seguem apresentando o desfavelamento como solução e resultam na construção de um consenso em torno dessa matéria.

A parte III corresponde a uma descrição densa das práticas referentes à execução dos programas habitacionais. Nesta parte, a dimensão do cotidiano dessas práticas é altamente explorada, buscando mostrar a "mecânica", o "como" dos programas habitacionais em questão, com ênfase nas soluções para as ocupações irregulares. 
No Capítulo 5 contextualizo a aprovação da Lei Federal no 11.977/2009 e a criação do PMCMV e do Programa de Regularização Fundiária de Assentamentos localizados em áreas urbanas. Neste capítulo, trago um breve panorama das referências que problematizam a criação do PMCMV, articulando-as à financeirização da habitação e à rearticulação dos agentes no contexto nacional. Abordo também a disputa em torno da regulamentação da regularização fundiária no Brasil e os novos instrumentos da Lei Federal no 11.977/2009.

No Capítulo 6 trato da implantação do Programa Minha Casa Minha Vida em Londrina, apresentando dados quantitativos e qualitativos para uma caracterização geral das negociações e dos efeitos territoriais. Destaco também os aspectos de ilegalidade que permearam grande parte dos procedimentos relacionados a esse programa. Por fim, foco nas práticas de remoção de famílias residentes em ocupações irregulares que foram realocadas nos conjuntos habitacionais do PMCMV. Para esta análise, aprofundo no caso das remoções para o Residencial Vista Bela, com dados quantitativos e aspectos procedimentais que caracterizam essa prática chamada de "remoção". Neste estudo, mostro que, apesar do discurso do risco e da preservação ambiental, as remoções foram, em grande parte, alavancadas pelo processo de reestruturação imobiliária da zona leste de Londrina.

No Capítulo 7 abordo o Programa de Regularização Fundiária realizado em Londrina. Primeiro, apresento aspectos da concepção do programa, como estabelecimento de metas e objetivos, e a definição das áreas a serem atendidas. Aprofundo o caso do Residencial São Marcos para contextualizar o enquadramento no programa no contexto da história dos assentamentos e ocupações. Na sequência, discuto o procedimento da regularização fundiária tal como foi concebido neste programa, em que a documentação referente ao registro do imóvel aparece como elemento central. A partir desta constatação, proponho uma breve análise do conceito de regularização fundiária, confrontando a abordagem deste programa ao conceito de regularização fundiária plena proposto pelos documentos do Ministério das Cidades.

No Capítulo 8 apresento os Cartórios de Registro de Imóveis como outro agente da política habitacional. A centralidade da documentação nos procedimentos da 
regularização, e as disputas em torno da gratuidade dos custos desses procedimentos evidenciam a importância atribuída a esse agente na concepção e execução desse programa. Para fazer uma caracterização dos cartórios, recupero aspectos históricos que aproximam a função do registro do pensamento proprietário e como este aspecto influencia na centralidade atribuída aos cartórios nos procedimentos da regularização fundiária. Ainda neste tópico, trago informações sobre o papel da regularização fundiária no processo que chamo de reestruturação dos procedimentos imobiliários no Brasil que vem ocorrendo nas duas últimas décadas.

A Parte IV corresponde a uma análise da gestão dos ilegalismos urbanos em Londrina. A partir da articulação entre referências teóricas sobre Estado, governo e poder, desenvolvo a argumentação propondo uma análise do Estado e da governamentalidade, e da constituição e da mecânica dos dispositivos de gestão. Estas análises que situam os agentes e os mecanismos de governo dão a base para o capítulo conclusivo que trata da gestão dos ilegalismos em Londrina.

Desse modo, no Capítulo 9, proponho a análise do Estado a partir do conceito de "margens do Estado" de Das e Poole (2004). Para a análise, os conceitos de governamentalidade, legitimidade e margens são fundamentais. A análise está estruturada com base na definição dos conceitos de margens do Estado proposta pelas autoras: análise das áreas onde aparentemente o Estado não atua, ou seja, a periferia; a análise a partir da documentação do Estado, ou o que Das (2004) chama de "assinatura do Estado"; e a análise do governo dos corpos, a partir da referência do biopoder de Foucault.

De forma sequencial, no Capítulo 10 proponho uma análise da mecânica do dispositivo de poder. Para isso, abordo os tipos de dispositivos propostos por Foucault, diferenciando o governo dos corpos e o governo da população, de modo que embase a análise da constituição de um dispositivo a partir da articulação das práticas, dos discursos, das leis, etc. observados no estudo dos programas habitacionais.

O Capítulo 11 traz argumentos conclusivos sobre a gestão dos ilegalismos e os programas habitacionais realizados em Londrina. A partir da forma de "mercadoria 
política" que a habitação de interesse social produzida pela Cohab-LD assume entre as diferentes gestões, as fronteiras da legalidade são constantemente renegociadas até a legitimação desse processo por meio da documentação. Desse modo, nessas negociações, deslocamentos populacionais gerados pelas remoções e a regularização (ou legalização) fundiária correspondem à parte deste processo de gestão diferencial dos ilegalismos que tem como principal objetivo a gestão do território em benefício da propriedade privada da terra. 


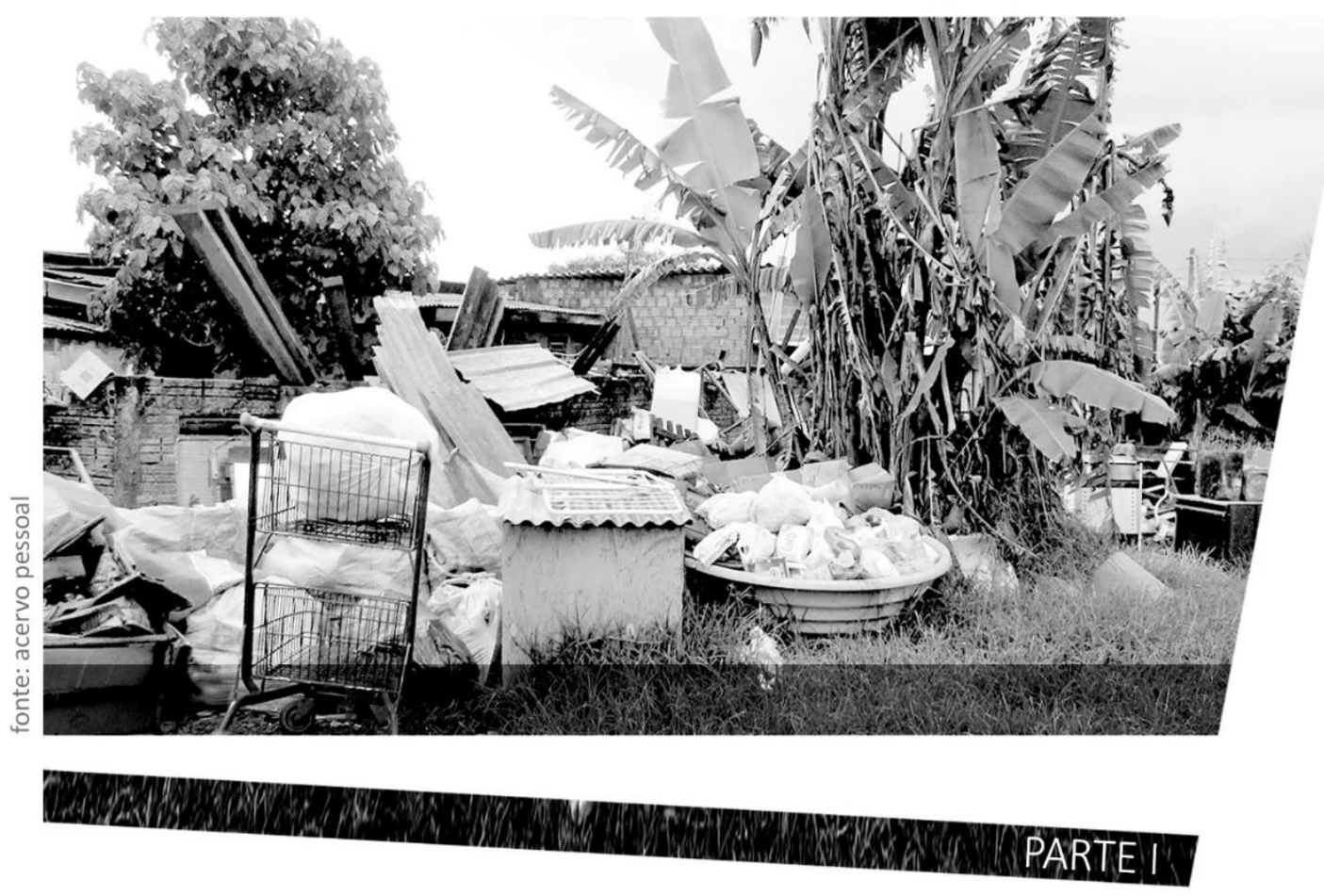




\section{Londrina, cidade planejada e a gênese da informalidade}

Trazer a discussão sobre a informalidade para o contexto londrinense é fundamental tendo em vista a cultura do planejamento urbano associada à fundação da cidade. Londrina foi implantada como parte de um empreendimento imobiliário idealizado pela empresa inglesa CTNP - Companhia de Terras Norte do Paraná -, que utilizou o discurso do planejamento urbano como marketing para a venda de terras. 0 discurso vingou e a região passou a ser descrita nos termos de "cidade planejada", já que o empreendimento compreendia núcleos urbanos e terrenos rurais.

Nesse sentido, interessa compreender como, nessa "cidade planejada" e de iniciativa privada, ocorreu a gênese da informalidade. O empreendimento privado não reservou terras para a população de baixa renda que buscou se empregar na cidade. Sendo assim, compreender a dinâmica econômica ao longo do desenvolvimento da cidade $^{34}$ nos permite analisar como a informalidade passa a constituir o cotidiano da cidade, permear as esferas de vida e estabelecer territórios.

\section{Mercado imobiliário e desenvolvimento econômico}

A implantação de Londrina aconteceu em um contexto de tensão nacional acerca da estrutura agrária consolidada no país. A intenção primeira da Companhia Sudão Plantations ${ }^{35}$ era estabelecer na região norte paranaense um grande latifúndio para plantio de algodão, entretanto, tendo em vista as tensões políticas, a negociação

\footnotetext{
${ }^{34}$ Sobre isso, o trabalho de Oliveira (2009) apresenta importantes contribuições ao explicar por qual motivo o setor de serviços, fortemente marcado pelo trabalho informal e precário, se desenvolve rapidamente na cidade de Londrina. Para o autor, a localização de Londrina como a "porta de entrada" do empreendimento demandou, para viabilizar as atividades da CTNP e para dar suporte ao escoamento da produção, o desenvolvimento precoce do setor terciário.

${ }^{35}$ A companhia inglesa que foi responsável pela colonização do Norte Paranaense chamava-se Sudão Plantations, pois era destinada à colonização para fins de agroexportação, como foco na produção de algodão, no Sudão. Após as negociações no Brasil quanto à ocupação dessa porção do Paraná funda a Paraná Plantations, ainda com a mesma finalidade de plantar algodão. Posteriormente, a Paraná Plantations foi transformada em Companhia de Terras Norte do Paraná - CTNP (Gonçalves, 1995).
} 
culminou em um parcelamento das terras em porções menores para fins de comercialização para pequenos e médios agricultores ${ }^{36}$. Essa determinação tinha relação com a crise de 29 que atingia principalmente os grandes proprietários de terras no Brasil que, possivelmente, não fariam investimentos naquele momento ${ }^{37}$. Por isso, 0 foco da Companhia teria sido o de atingir uma parcela de imigrantes e potenciais agricultores de pequeno e médio porte.

Assim, a fundação de Londrina na década de 30 do século XX fez parte de um empreendimento imobiliário de escala regional implantado pela empresa inglesa Paraná Plantations - posterior Companhia de Terras Norte do Paraná, CTNP - para fins de venda de lotes urbanos e rurais. Esse empreendimento resulta da negociação da dívida do Brasil com agências multilaterais inglesas ${ }^{38}$.

A compreensão das decisões relativas ao modelo de implantação do empreendimento não pode deixar de considerar que o início da década de 30 corresponde a um momento de crise econômica mundial e um período de transição no Brasil entre o fim da hegemonia da produção agrícola para fins de exportação e a instauração da produção de base urbano-industrial ${ }^{39}$. Outro fator fundamental do contexto nacional era a abolição dos incentivos à produção de café no Estado de São Paulo somada aos incentivos ao novo padrão de acumulação pautado na produção industrial e no trabalho assalariado urbano. O papel da produção cafeeira nesse momento representava apenas a necessidade de sustentar principalmente as importações necessárias para a promoção da industrialização ${ }^{40}$.

Na década de 1920 havia a pressão sobre os fazendeiros do oeste paulista para a incorporação da porção norte paranaense ao circuito da economia, tendo em vista as

\footnotetext{
${ }^{36}$ Gonçalves (1995).

${ }^{37}$ Oliveira (2007).

${ }^{38}$ Amorim (2015). Segundo Tomazi (1997), durante a negociação e aquisição das terras pela Companhia, o governo do estado contraiu empréstimo do Banco Inglês para investimentos no Porto de Paranaguá.

${ }^{39}$ Oliveira (2003).

40 Oliveira (2009). Sobre isso, cabe destacar o caráter de exceção que se configura já no início da implantação do empreendimento e evidencia a proximidade entre Estado e direção da Companhia de Terras. Em fevereiro de 1931, o Decreto Federal no 19.688 proibiu o plantio de novos pés de café em todo o país. Logo após o Decreto houve uma reunião entre os diretores da Companhia de Terras e o interventor Mário Tourinho que garantiu que o Paraná ficasse de fora dessa normativa (Tomazi, 1997).
} 
limitações econômicas do Paraná naquele período. Era uma grande área de solos férteis que só poderia realizar a renda diferencial dessa característica do solo na agricultura com a implantação de transporte moderno ${ }^{41}$. Por isso, toda a negociação pela qual passou essa porção do território estava relacionada à implantação da ferrovia que deveria conectar essa área à Ferrovia "Sorocabana".

Apesar do papel da Companhia de Terras na estruturação do território, cabe destacar que o Estado participou ativamente dos processos de decisão, principalmente cedendo aos interesses da empresa. Isso corrobora as afirmações de Francisco de Oliveira ${ }^{42}$ de que as intervenções do Estado não são limitadas à economia e que são responsáveis pela criação das cidades brasileiras. O autor utiliza o exemplo das cidades do interior de São Paulo que também foram implantadas às margens de ferrovias que, apesar de serem privadas, o subsídio às exportações era dado pelo Estado. A partir dos fatos descritos verifica-se que esse também é o caso das cidades do Norte do Paraná.

A produção cafeeira é um dos principais exemplos utilizados por Francisco de Oliveira (2003) para mostrar como a ação do Estado era necessária na regulação da economia preservando-a das oscilações do mercado, como é possível ver na atuação do IBC, confiscos, entre outros. Entretanto, a ação do Estado está sempre a serviço das empresas e bancos, sobretudo internacionais. A cafeicultura forneceu as bases para o desenvolvimento econômico da cidade de Londrina, que se consolida efetivamente a partir da década de 1940.

O empreendimento do Norte do Paraná não foi a única experiência de colonização dirigida da região, mas teve destaque em relação às demais em função da amplitude da área ${ }^{43}$ e a lógica de implementação e distribuição dos lotes. A localização de Londrina na totalidade do empreendimento foi determinante na estruturação

\footnotetext{
${ }^{41}$ Oliveira (2007).

42 Duarte e Barros (2013).

${ }^{43} \mathrm{O}$ empreendimento foi implantado em uma área de 1.246 .341 ha, somada a 605.000 ha adquiridos pela construção da ferrovia (Oliveira, 2009). O projeto previu a estruturação de uma complexa rede viária composta por estradas vicinais conectando as propriedades rurais aos núcleos urbanos que foram instalados ao longo das rodovias principais e da ferrovia. Essas foram as responsáveis por conectar a região ao centro dinâmico de São Paulo e aos principais portos: de Santos e, posteriormente, ao de Paranaguá (Oliveira, 2009).
} 
econômica e para o desenvolvimento da cidade. A figura 1 mostra o mapa da colonização do Norte do Paraná. A figura 2 mostra a localização de Londrina e ilustra as principais características do arranjo espacial promovido pela Companhia de Terras.

Figura 1 - Colonização do Norte do Paraná

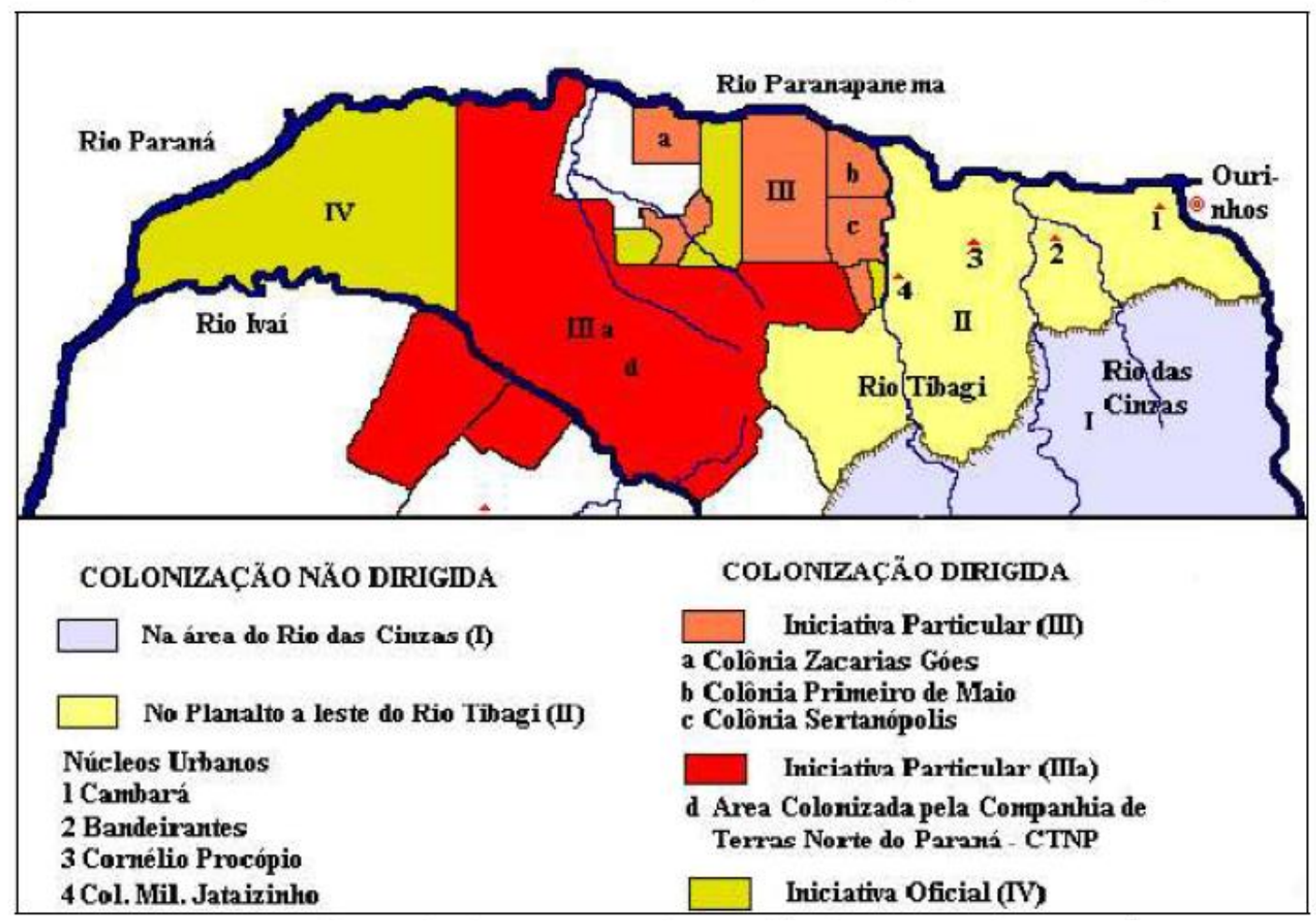

Fonte: Oliveira (2009) 
Figura 2 - Localização dos principais núcleos urbanos na totalidade do arranjo espacial promovido pela Companhia de Terras

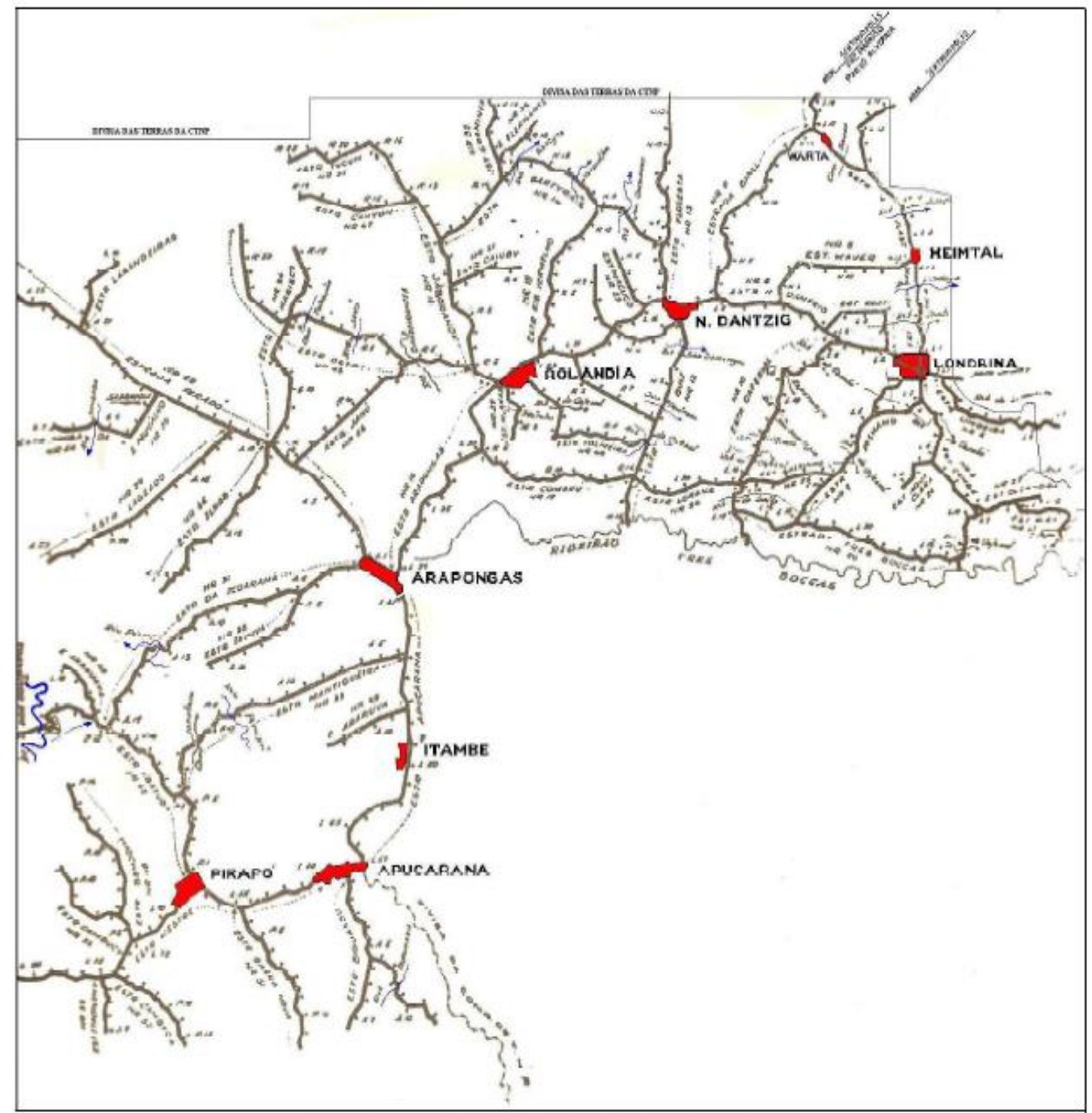

Fonte: Yamaki, 2003

Alguns fatores se destacam no arranjo espacial promovido pela Companhia de Terras. A partir das cidades principais em que os lotes foram parcelados em dimensões para fins urbanos, os lotes rurais mais próximos a essas áreas urbanas tinham porte de chácaras, que seriam voltadas à produção de hortifrutigranjeiros para abastecimento do núcleo urbano, e aumentavam progressivamente de tamanho na medida em que se distanciavam dos núcleos urbanos até as propriedades maiores destinadas à agricultura de exportação ${ }^{44}$.

44 Oliveira (2007). Sobre o parcelamento definido pela Companhia (pode ser visto adiante na figura 3), Amorim (2015, p.58) diz que esse modelo foi chamado na época de "reforma agrária liberal", termo 
A produção prevista no contexto do empreendimento estava em consonância com a reflexão de Francisco de Oliveira (2003, p. 297),

(...) um complexo de soluções, cujas vertentes se apoiam no enorme contingente de mão de obra, na oferta elástica de terras e na viabilização do encontro desses dois fatores pela ação do Estado construindo a infraestrutura, principalmente a rede rodoviária. Ela é um complexo de soluções cujo denominador comum reside na permanente expansão horizontal da ocupação com baixíssimos coeficientes de capitalização prévia: numa palavra, opera como uma sorte de 'acumulação primitiva'.

Mesmo com o início do processo de industrialização do país, o modelo do empreendimento evidencia o papel da agricultura no contexto nacional e a intenção de mantê-la ativa tanto para a exportação como para o abastecimento interno para suprir demandas das áreas urbanas, longe de representar qualquer tipo de obstáculo. 0 modelo não previa a implantação de áreas industriais, o que mostra que o papel da cidade era o de servir como centro de negócios e serviços para atender as atividades de exportação.

Londrina foi implantada estrategicamente na região, na porção do extremo oeste do empreendimento. A instalação nesse ponto permitiu a articulação de Londrina com o restante da região, principalmente com o Estado de São Paulo, confirmando sua principal função de abrigar os escritórios da companhia, principalmente os responsáveis pelas vendas dos lotes, comandando a produção espacial de todo o empreendimento da Companhia. Em função de sua posição, servia como "porta de entrada" e "cartão de visitas" aos compradores ${ }^{45}$.

\footnotetext{
também discutido por Gonçalves (1997). Segundo Gonçalves (1995, p.48) esse argumento decorria da distinção desse modelo de parcelamento - pequenos lotes rurais e urbanos - do modelo agrário vigente no restante do país, marcado pelo "alto grau de concentração fundiária e de controvérsias intermináveis sobre posse e propriedade". Além disso, as propostas de preços acessíveis com formas facilitadas de pagamento dos terrenos permitiam a ascensão de trabalhadores e pequenos proprietários. Muitos deles enriqueceram rapidamente no território paranaense.

${ }^{45}$ Oliveira (2009, p.37).
} 
Por causa disso, a área urbana de Londrina teve que ser dotada de infraestrutura para viabilizar e estruturar uma economia urbana e, assim, dar suporte às atividades comerciais da Companhia de Terras, permitindo aos ingleses e seus sucessores uma ampla e "lucrativa recuperação desses investimentos" em função da valorização que essa infraestrutura possibilitou posteriormente ${ }^{46}$.

Em 1934 Londrina constituiu-se como municipalidade, mas o monopólio dos terrenos continuou sob o comando da Companhia de Terras garantido com a nomeação do diretor da Companhia Willie Davis como prefeito ${ }^{47}$. Como a rede viária implantada pela Companhia era bastante extensa, sua manutenção configurava um problema por excesso de gastos. Com a municipalidade, passaram a ser cobrados impostos para essa finalidade.

Com a conexão ferroviária completa e as primeiras colheitas, a cidade cresceu sempre acompanhando o desenvolvimento da produção agrícola da região. Além de ser a maior cidade da rede implantada, em função desse papel econômico que Londrina assumiu no empreendimento, o Setor de Serviços se desenvolveu consideravelmente na cidade.

Francisco de Oliveira (2003) realça o papel do Setor de Serviços no processo de acumulação, mostrando que apesar de ser considerado fora do setor produtivo, serviu como base, ou "acumulação primitiva" para o desenvolvimento industrial, que não poderia ocorrer sem o apoio dessas atividades. Esse já é um primeiro ponto considerado relevante para compreender a veloz industrialização de Londrina.

Na década de 1940, com a cafeicultura da região bem consolidada e o avanço da indústria no cenário nacional, todos os lotes do centro principal projetado pela companhia já estavam vendidos. Na mesma década avançaram também as construções das vilas nas periferias da cidade, sendo que em 1947 já existiam 53 vilas em Londrina ${ }^{48}$.

\footnotetext{
${ }^{46}$ Oliveira (2009, p. 33).

47 Oliveira (2009). Amorim (2015) chama a atenção para a articulação presente desde o processo de colonização até hoje entre mercado imobiliário e poder público local. Argumenta que muitas vezes membros do executivo assim como os próprios legisladores são também agentes imobiliários e, por isso, se beneficiam em grande medida dos processos de valorização imobiliária.

${ }^{48}$ Oliveira (2009).
} 
As vilas eram resultado do reparcelamento das chácaras destinadas à produção de hortifrutigranjeiros limítrofes à área urbana, e se desenvolveram como uma medida de exceção para solucionar o problema dos compradores de chácaras que não conseguiram arcar com o preço total pedido pela Companhia. A solução encontrada foi parcelar estas chácaras e vender os lotes a preços mais acessíveis e, por meio destes pagamentos, quitar a dívida com a Cia de Terras. É assim que começa a formação da "periferia" de Londrina $^{49}$.

Figura 3 - Localização das principais vilas de Londrina no final da década de 50

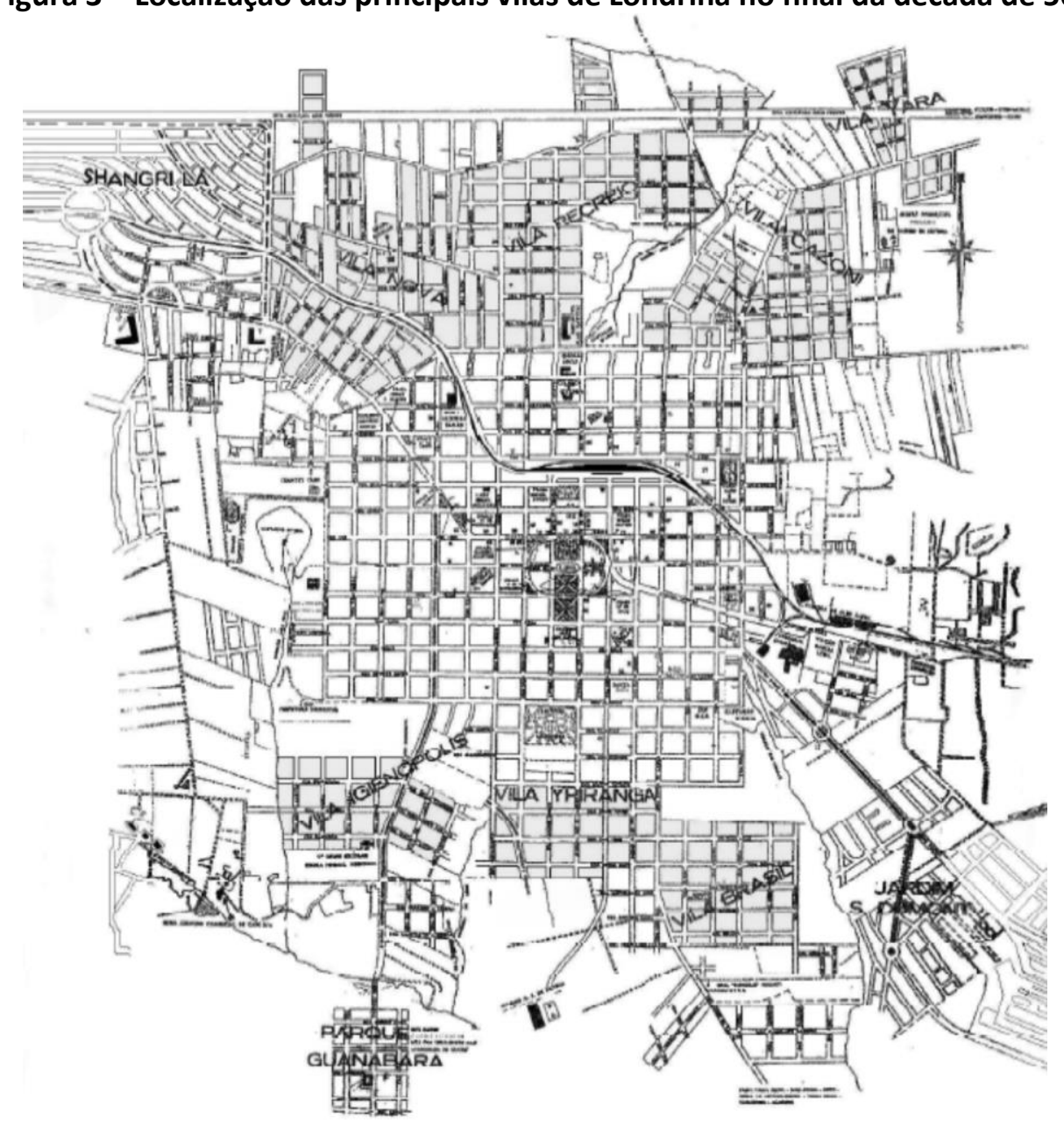

Fonte: Yamaki, 2003

\footnotetext{
${ }^{49}$ Segundo Alves (2002), a primeira Vila da cidade foi a Vila Casoni, primeiro bairro construído a norte da linha do trem, onde passaram a residir em casas de madeira trabalhadores da área da construção civil, oficinas, marcenarias, carpintarias, e comércios menores, assim como mulheres empregadas no trabalho doméstico.
} 
O extremo sul da Figura 4, identificado como "Parque Guanabara", corresponde a uma ocupação irregular que, posteriormente, foi urbanizada com recursos do Projeto CURA. Os compradores dos lotes das vilas - preços bem abaixo dos terrenos vendidos pela Companhia - eram principalmente trabalhadores da companhia e da área urbana. Oliveira (2009, p.57) descreve as características desta área: “Essas extensões irregulares do meio construído não possuíam as mesmas condições da parte da cidade construída pela Cia de Terras. O traçado era irregular e faltavam a infraestrutura e os equipamentos urbanos $(\ldots)^{\prime \prime}$

\section{Sem lugar para os pobres na cidade}

A partir da década de $50^{50}$ começou a progressiva substituição da produção cafeeira por grãos (soja e milho), produção altamente mecanizada e, por isso, grande parte da mão de obra deixou a zona rural em direção à área urbana neste período. Além disso, pequenos proprietários que não acompanharam o desenvolvimento também migraram para a periferia de Londrina, pois parte deles "não foi absorvida pelo mercado de trabalho na zona rural ou não conseguiu saldar suas dívidas com a compra do lote de terras, transferindo-se para as periferias da cidade, sendo forçada a sobreviver do trabalho temporário ou volante" ${ }^{15}$. Dessa forma, já em meados da década de 50 formouse a primeira favela, a "Vila do Grilo", a leste do centro da cidade.

Em 1950 já eram mais de 6.000 edificações, incluindo edifícios de vários andares, evidenciando o crescimento da construção em alvenaria. Rápido desenvolvimento da construção civil que iniciava seu processo de industrialização, simultâneo ao processo artesanal da construção de casas de madeira nas vilas ${ }^{52}$.

\footnotetext{
50 Francisco de Oliveira (1982) descreve que na década de 1950 a economia brasileira apresenta características distintas do período anterior, decorrente da relação que se estabelece entre o Estado e o urbano na economia e na sociedade e a instalação consequente do capitalismo monopolista. Segundo o autor, sob pressão dos países capitalistas, o Estado brasileiro é forçado a investir em outros setores produtivos, alavancando as empresas estatais desse período.

${ }^{51}$ Alves (2002, p.87).

52 Oliveira (2009, p. 37).
} 
Na década de 1950 a administração dos lotes da Companhia de Terras já havia sido passada a grupos econômicos nacionais formados, principalmente, por empresários paulistas. Em 1951, a administração municipal aprovou a primeira Lei que tinha como objetivo o ordenamento da área urbana, por meio do estabelecimento de regras de parcelamento, ocupação e uso do solo urbano. A Lei citava como objetivos, além do ordenamento da expansão de loteamentos, o embelezamento da cidade.

É justamente nesse período que surgem e se proliferam as ocupações irregulares na cidade pela população de baixa renda vinda em busca de empregos em função do avanço da cidade e da substituição de mão de obra nas lavouras. Nesse compasso do desenvolvimento econômico de Londrina se desenvolvem também os "bolsões de pobreza" urbana ${ }^{53}$. Os contrastes eram cada vez mais evidentes ${ }^{54}$. As ocupações irregulares desse período estavam localizadas a leste e a norte da área urbana. Nesses pontos a ocupação de baixa renda é, em grande parte, tolerada ${ }^{55}$ e vai persistir até os dias de hoje. Já na região sudoeste onde algumas ocupações irregulares apareceram de forma pontual não houve a mesma tolerância.

Entre as décadas de 50 e 60, a população da área urbana aumenta de 17.395 habitantes para 56.287, passando significativamente a população rural, porém nem toda essa população foi absorvida pelos empregos na cidade ${ }^{56}$. Com base na tabela 1 , fica claro que esse aumento populacional urbano se deu em grande parte pela população de baixa renda.

\footnotetext{
${ }^{53} \mathrm{O}$ termo "bolsões de pobreza" é utilizado por Ferreira (1999), que aponta que o problema da extrema pobreza em Londrina tem início com os movimentos de migração dos trabalhadores da área rural para a área urbana.

${ }^{54}$ Segundo Oliveira (2009, p. 51), nesse período, Londrina concentrou "diferentes tipos de trabalho e de trabalhadores: a sofisticação da doceria alemã e do sorveteiro italiano à simplicidade dos entregadores de carroça, dos ajudantes de cozinha e de limpeza, dos vendedores e vendedoras, entre outras".

${ }^{55}$ Acredito que essa tolerância ocorreu já que as ocupações se deram nas áreas residuais da abertura da Rodovia BR 369 e a leste, nos limites da área da CTNP.

${ }^{56}$ Alves (2002).
} 
Tabela 1 - Tipos de Construção em Londrina

\begin{tabular}{cccc}
\hline CONSTRUÇÃO/ANOS & RESIDENCIAIS & COMERCIAIS & POPULARES \\
\hline 1963 & 74 & 78 & 92 \\
\hline 1964 & 81 & 100 & 157 \\
\hline 1965 & 92 & 74 & 366 \\
\hline 1966 & 43 & 65 & 200 \\
\hline
\end{tabular}

Fonte: Alves (2002)

De acordo com Francisco de Oliveira (2003), é na combinação de padrões considerados "primitivos" de acumulação com as novas relações que se estabelecem no setor agrícola é que estão as bases da concentração de renda da economia e, sobretudo, das cidades brasileiras. $O$ fornecimento dos alimentos a preços mais baixos, a formação do "exército de reserva" e a alimentação dos serviços urbanos sustentava a economia da cidade. Nesse sentido, ele argumenta que o setor da economia agrícola alimentou a expansão capitalista no Brasil.

Isso fica claro no desenvolvimento de Londrina, principalmente a partir dos anos 60 com o avanço da industrialização, que cresceu rapidamente tendo em vista o suporte de serviços e infraestrutura já consolidados, em decorrência da posição estratégica de Londrina no contexto do empreendimento de bases agrícolas da Companhia de Terras Norte do Paraná. Progressivamente, entre 1960 e a década de 1970 a agricultura deixou de ser a base da economia urbana. 
Figura 4 - Desenvolvimento dos setores da economia urbana de Londrina entre as décadas de 50 e 70.

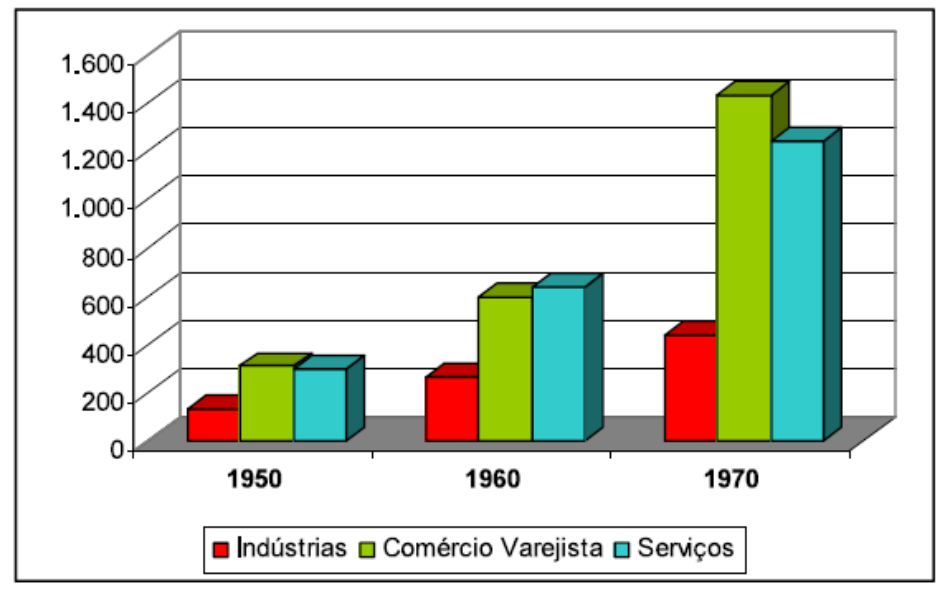

Fonte: Oliveira, 2009

Concomitantemente ao avanço da industrialização nesse período, multiplicamse também as favelas, como a Vila Fraternidade, Vila do Grilo e do Pito Aceso evidenciando o aumento progressivo da situação de pobreza de parte da população ${ }^{57}$. Nesse sentido, observando o avanço da industrialização e do circuito inferior junto aos bolsões de pobreza, fica claro como a pobreza e a formação cultural dos trabalhadores vindos do campo alimentou o desenvolvimento do setor moderno da economia.

Entre as décadas de 60 e 70 com a progressiva substituição da produção de café pelos grãos ${ }^{58}$, intensificou-se o êxodo rural e em decorrência da estrutura do mercado formal, há um aumento das ocupações irregulares. Segundo dados da Cohab-LD, no ano de 1970 Londrina já possuía 9 favelas: “Grilo, Bom Retiro, Esperança, Pito Aceso, Grilinho, Boa Vista, Novo Mundo, Vila Paulista e Marísia"59 (esta última ainda permanece).

Durante a década de $1970^{60}$ importantes transformações na economia de Londrina ocorreram principalmente decorrentes dos avanços do meio técnico-

\footnotetext{
57 Segundo Oliveira (2009, p. 58) “os embriões do circuito inferior aparecem nas formas pelas quais os moradores das vilas e favelas de Londrina enfrentavam o desafio de sobreviver na cidade".

58 Alves (2002).

${ }^{59}$ Dados apresentados por Alves (2002, p. 182)

60 Nesse período outro fator influencia esse processo e evidencia o papel do Estado na promoção da industrialização, e consequente urbanização, discutido por Francisco de Oliveira (1982; 2003). O Projeto Paraná alavancado pelo governo do Estado no fornecimento de infraestrutura demandada pelos processos de industrialização chega a Londrina com o fornecimento por empresas estatais de energia
} 
científico-informacional, resultando na modernização da agricultura na região e energização da urbanização. Dessa forma, a economia urbana tornou-se cada vez mais independente da produção agrícola e a população e os trabalhadores tornaram-se majoritariamente urbanos e, assim, as atividades urbanas assumiram novos papéis ${ }^{61}$.

O avanço das lavouras mecanizadas de soja e trigo e a implantação de agroindústrias reconfigurou a inserção de Londrina na divisão territorial do trabalho nesse período. A rápida tecnificação do campo e das transformações provocadas por essa reestruturação na configuração espacial e do trabalho na região que resultou no "aumento da área média dos estabelecimentos, a redução do número de parceiros e colonos, e aumento do número de trabalhadores volantes intensificou as migrações em direção às áreas urbanas"62.

Figura 5 - Avanço das lavouras mecanizadas em Londrina

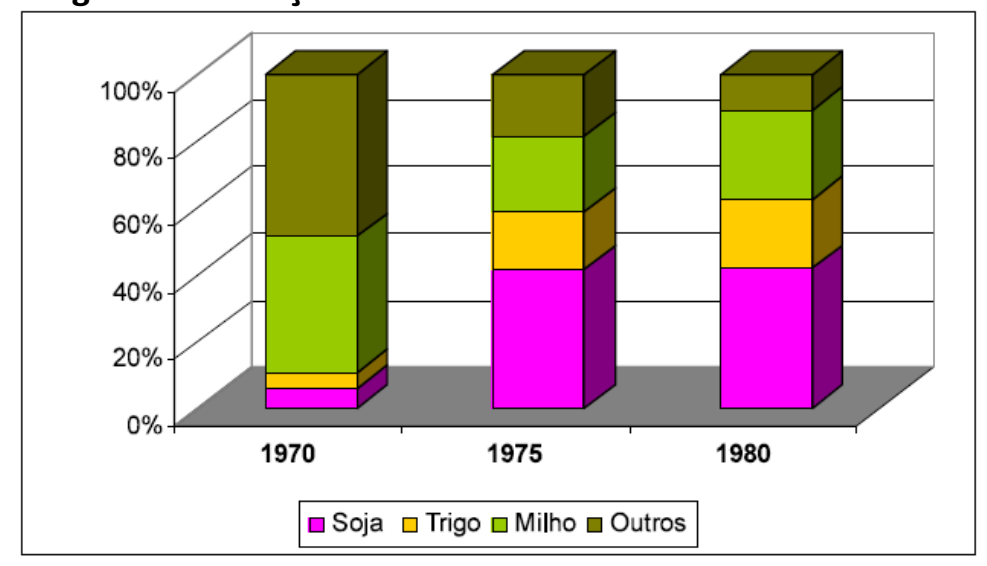

Fonte: Oliveira, 2009

elétrica (pela COPEL - Companhia Paranaense de Energia), e de redes de saneamento (pela SANEPAR Companhia de Saneamento do Paraná).

${ }^{61}$ Oliveira (2009).

62 Oliveira (2009, p. 71). 
Figura 6 - Crescimento população urbana em Londrina

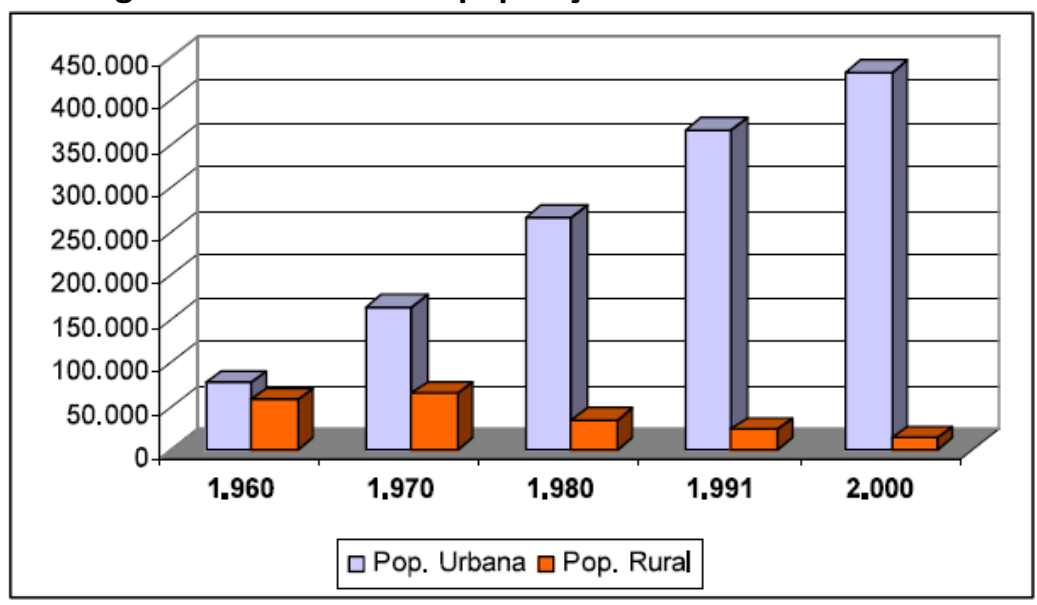

Fonte: Oliveira, 2009

Esse processo contribuiu para o crescimento do "exército de reserva" na área urbana, que é parcialmente absorvido pelas indústrias de transformação, principalmente no ramo do vestuário e da construção civil, e pelo Setor Terciário, que cresceu significativamente acompanhando a intensificação da industrialização.

Para Francisco de Oliveira (1982, p.55),

Esse é na verdade o maior determinante do fato de que a nossa industrialização vai gerar taxas de urbanização muito acima do próprio crescimento da força de trabalho empregada nas atividades industriais. Isso, retomando uma de nossas primeiras observações, vai dar lugar ao que a sociologia vulgar chamou de urbanização sem industrialização e a toda teorização sobre o "inchaço" e a marginalidade social nas cidades. Não se quer dizer que não haja marginalidade social nas cidades, mas essa marginalidade social é, ela mesma, um componente dos exércitos industriais de reserva. Não significa, tal como a teorização da marginalidade social tenta dizer, exclusão do mercado de trabalho, nem exclusão da economia urbana. Significa a forma peculiar pela qual a industrialização brasileira trouxe para dento de si, de uma só vez, de uma pancada, todo esse exército industrial de reserva, vindo dos campos para dentro das cidades.

No plano da Companhia de Terras foram disponibilizadas áreas para a implantação de edifícios institucionais como a Prefeitura, biblioteca, hospitais, escolas, entre outros. No entanto, não foram destinadas áreas para implantação de indústrias. Por isso, o poder público teve que dispor de áreas primeiramente a leste do centro 
principal e, posteriormente a oeste para a implantação das empresas. Foram exatamente nas proximidades dessas áreas, margeando as principais vias de circulação ou os córregos que surgiram as favelas desse período, formadas principalmente pelos trabalhadores das indústrias recém-instaladas.

Durante a década de 90, há uma segunda fase de expansão da economia urbana de Londrina resultando na incorporação aos fluxos da globalização, porém com índices elevadíssimos de desemprego ${ }^{63}$. Nesse mesmo período, confirmando a crítica de Francisco de Oliveira, é o período de maior avanço das ocupações informais que aumentaram exponencialmente. De acordo com as pesquisas de Ferreira ${ }^{64}$, entre as décadas de 1980 e 1990 o número de famílias residindo em favelas aumentou 140\%.

Decorrente da ampla área de Preservação Permanente protegida pela Lei de 1951, da escassez de áreas públicas e das ofensivas dos proprietários fundiários, as ocupações irregulares aconteceram substancialmente nas áreas de preservação dos extensos fundos de vale que cortam a cidade no sentido leste-oeste, nas margens das vias que dão acesso à cidade e nas áreas de transição entre a zona rural e urbana. Essas áreas eram ocupadas pela população desempregada ou empregada no setor informal.

63 Oliveira (2009).

${ }^{64}$ Dados de Ferreira (1983) e Ferreira (1999), apresentados por Alves (2002). 
Figura 7 - Bolsões de pobreza em Londrina - década de 90

Londrina = belsôes e

pontos de pobreza

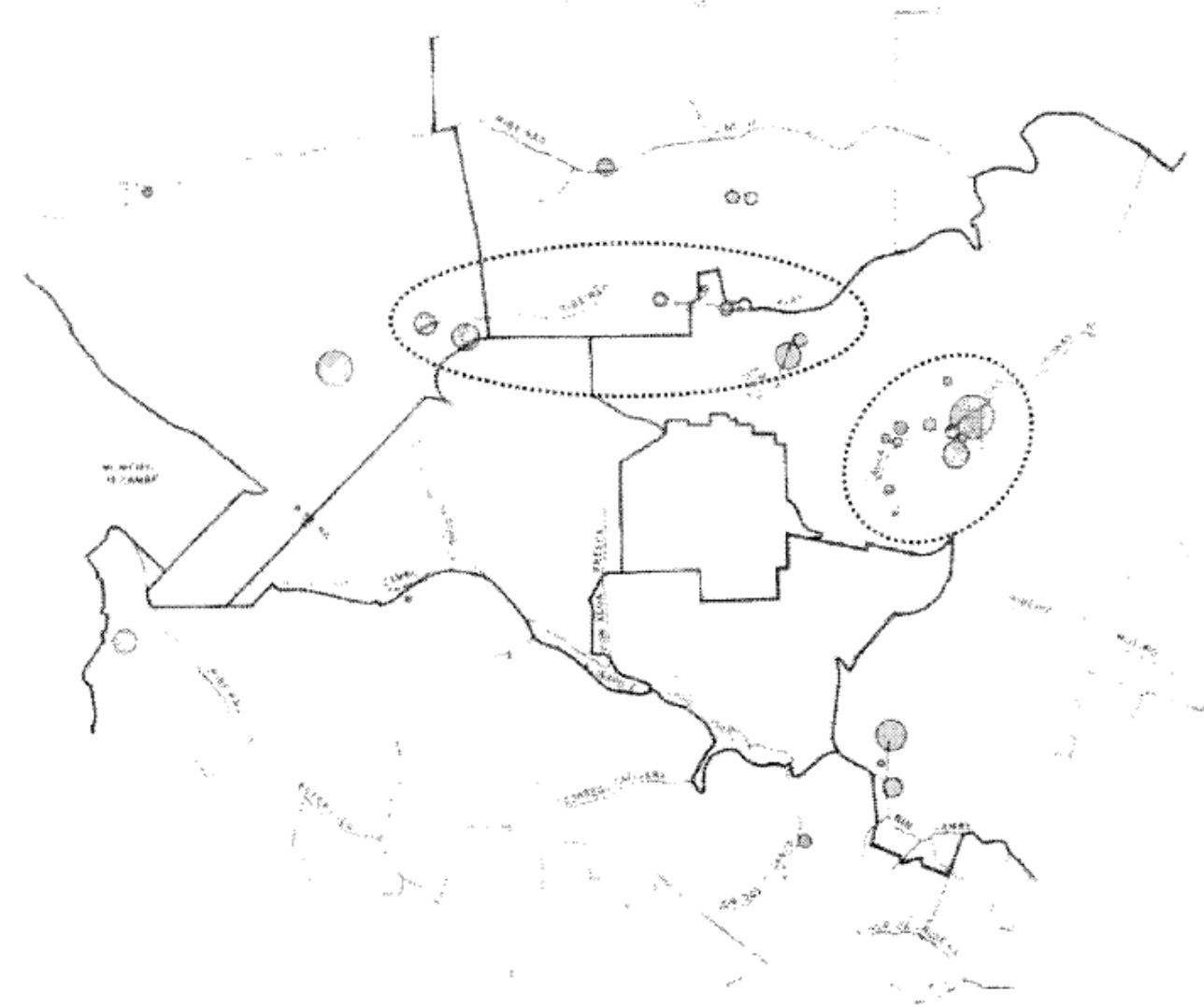

LEGENDA:

Favelas/Assentamentos

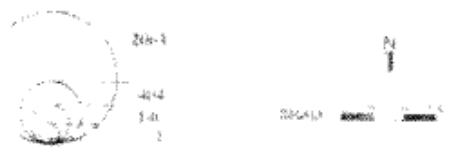

Org Grupo laterdisciplinat de Fesquisatuet Mapa da Fome 1995

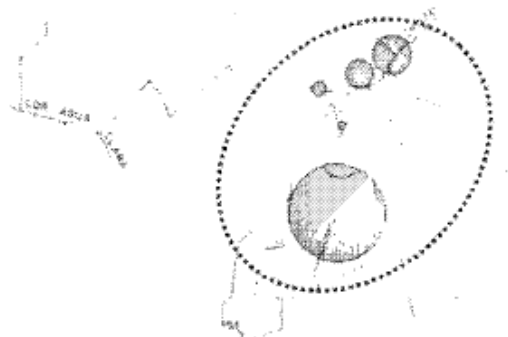

Fonte: Ferreira (1999)

O maior Bolsão, localizado na região sul, compreende os bairros Franciscato I, Franciscato II, Novo Perobal, Núcleo Cristal, Núcleo Jd Itapoã e União da Vitória (I a IV), o maior e mais recente entre eles. Este último teve início nos anos 80 com intensificação da ocupação na década de 90, época em que foram atingidos os maiores índices de desemprego de Londrina. O Bolsão localizado a norte da área urbana concentra os núcleos da favela da Caixa Econômica (atual CH Nossa Senhora da Paz) e favela Marizia (atual Vila Marizia), alguns dos mais antigos de Londrina. Outro bolsão que se destaca 
localiza-se na zona leste onde também se concentram as favelas mais antigas da cidade. Todos esses núcleos identificados continham, na década de 90, aproximadamente 20.000 pessoas $^{65}$.

Apesar do impulso da industrialização da década de 70, o setor terciário é o que mais emprega em Londrina. No setor industrial destaca-se a indústria da construção civil. Segundo dados do cadastro da Cohab-LD ${ }^{66}$, os residentes das ocupações irregulares são pessoas desempregadas, empregadas no setor informal ou empregadas em cargos de serviços gerais, indústria têxtil e construção civil e em estabelecimento de comércio e serviços, com renda de aproximadamente um salário mínimo.

O levantamento realizado em 2016 pela Cohab-LD mostra que, apesar da dispersão de pequenos núcleos precários a oeste e principalmente a norte, as áreas identificadas por Ferreira (1999) continuam concentrando os assentamentos mais precários de Londrina. Pelo mapa, fica claro que o centro e a região sudoeste, as mais valorizadas da cidade, não possuem ocupações irregulares. Como mostrarei adiante, a gestão destas ocupações irregulares realizada pela Cohab-LD procurou mediar os conflitos fundiários favorecendo os proprietários de terras levando a uma concentração das ocupações em áreas públicas, principalmente nas margens dos fundos de vale. Recentemente, decorrente da crise e dos altos índices de desemprego, o número de famílias residentes nas ocupações irregulares aumentou exponencialmente seguindo este mesmo padrão de ocupação.

\footnotetext{
${ }^{65}$ Ferreira (1999).

${ }^{66}$ Dados coletados em 2018 dos cadastros realizados até 2011 para as famílias atendidas pelo Programa Minha Casa Minha Vida.
} 
Figura 8 - Mapa dos assentamentos informais de Londrina - 2016

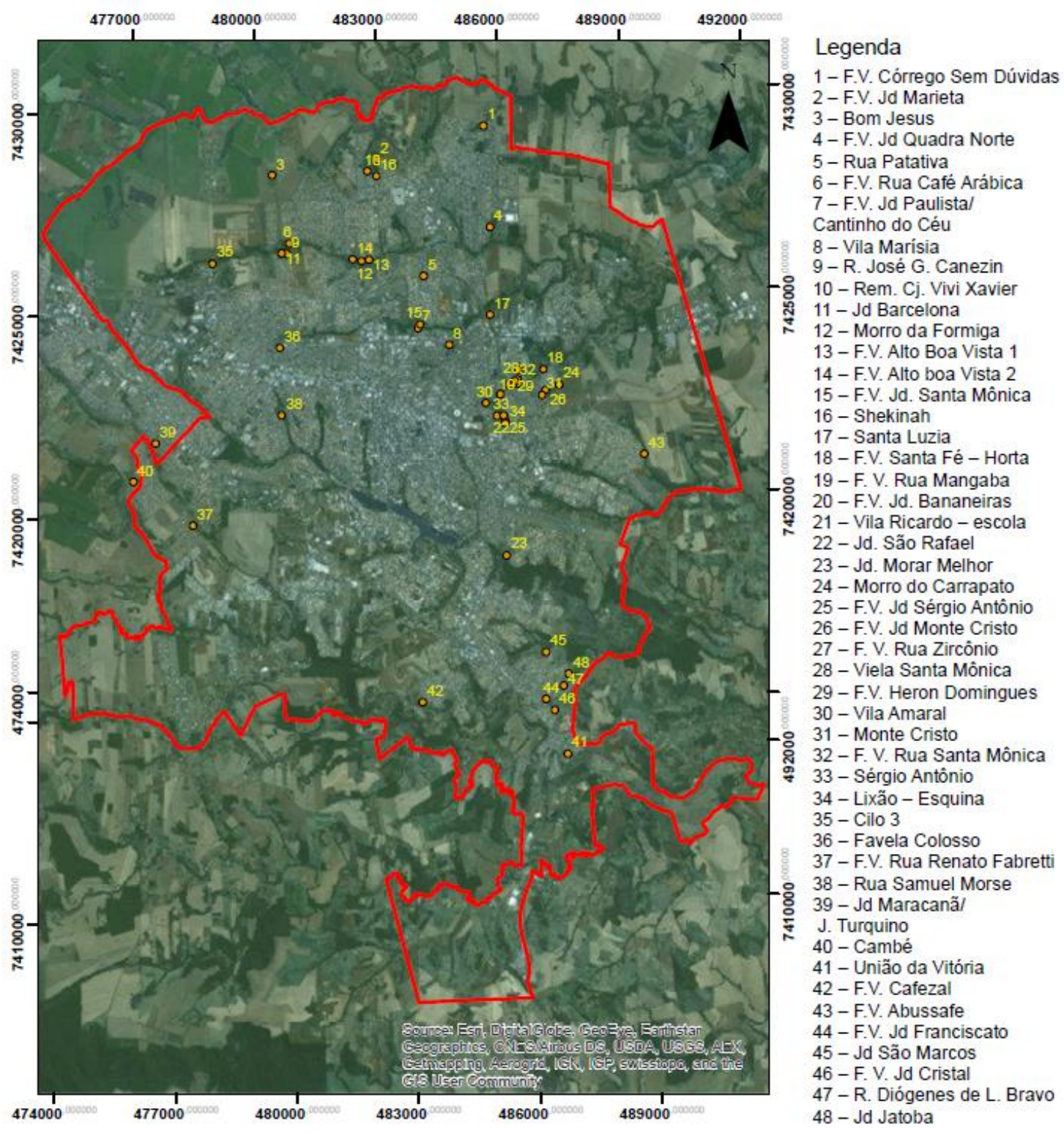

Projeção UTM

SIRGAS $200022 \mathrm{~S}$

Letícia de Castro

Univerisade Estadual de Londrina - UEL

Sistema de Informação Geográfica de Londrina - SIGLON

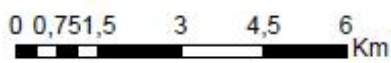

Fonte: Elaborado por Letícia Castro (2016). 


\section{O papel da Cohab-LD para além da produção habitacional}

A Cohab é uma imobiliária ${ }^{67}$.

Nesta parte traço um panorama da história da Cohab-LD ${ }^{68}$, evidenciando aspectos que influenciaram a consolidação do modo de operar que condiciona as práticas de gestão por meio dos programas habitacionais. Entendo que esse modo de operar está apoiado no tecnicismo, no "desfavelamento", na gestão empresarial e na especulação imobiliária. Neste breve panorama histórico costuro dados e informações sobre a atuação da Cohab-LD para tornar evidente estas características.

\section{A criação das Cohabs e a política do BNH}

A Companhia de Habitação de Londrina - Cohab-LD - foi criada pela Lei Municipal no 1.008/1965. Por determinação da Resolução no 11 de 03/09/1979/BNH Banco Nacional da Habitação, que dispõe sobre a criação das Companhias de Habitação, a Cohab-LD é uma sociedade formada por ações de economia mista, vinculada à Prefeitura Municipal de Londrina - maior acionista - por administração indireta ${ }^{69}$. De acordo com o Estatuto Social da Cohab-LD, a empresa deve responder às regras do Sistema Financeiro da Habitação ou do Sistema Financeiro Imobiliário. Como finalidade da Companhia está definida no Art. 3ํ,

Produção e comercialização de unidades habitacionais, principalmente as de interesse social (...); Promoção de programas de urbanização e/ou reurbanização de áreas, principalmente as ocupadas por favelas e habitações precárias, inclusive na aquisição de terrenos amigável ou judicialmente; Aquisição, urbanização, administração e

\footnotetext{
${ }^{67}$ Frase dita a mim pelo representante do Centro de Direitos Humanos de Londrina, em uma conversa em 31 de janeiro de 2019, sobre a atuação da Cohab-LD nas negociações com a ocupação Flores do Campo.

${ }^{68}$ Eu proponho o estudo dessa caracterização para revelar e diferenciar na análise aquilo que é singular na prática da Cohab-LD daquilo que é novo nos procedimentos trazidos pela Lei Federal no 11.977/2009. 69 Informações do Estatuto Social da Cohab-LD.
} 
venda de imóveis; Aquisição e venda de imóveis destinados a industrialização e que possam promover a oferta de mão-de-obra em localidades de população carente, segundo as diretrizes da CODEL; Apoio e execução de programas e projetos de desenvolvimento comunitário.

As empresas que são sociedades de economia mista são regulamentadas pelo Decreto-Lei no 200 de 1967, que institui a Sociedade de Economia Mista. Estas empresas foram criadas para a "exploração de atividade econômica" na forma de uma Sociedade Anônima, em que a maioria dos votos nesta sociedade deve pertencer à Entidade de Administração Indireta que, no caso das Cohabs, são as prefeituras municipais.

No contexto do Banco Nacional da Habitação - $\mathrm{BNH}^{70}$, a criação das empresas de economia mista preconizou a adoção da racionalidade empresarial na gestão dos recursos para, assim, reduzir o ônus gerado ao tesouro nacional, equilibrando o que os idealizadores do BNH chamaram de objetivos sociais e desempenho econômico do banco $^{71}$.

Muitas evidências mostram que somente os objetivos econômicos podem ser considerados satisfatórios já que o "estilo empresarial" do banco, que cobrava taxas de urbanização de assentamentos e preços de unidades habitacionais muitas vezes acima do valor de mercado, levou à necessidade de aumentar a faixa de renda do público alvo para acima de três salários mínimos como forma de superar os problemas de inadimplência na década de 70. Isto fez com que a suposta clientela prioritária fosse abandonada ${ }^{72}$ e “(...) já não [era] necessário buscar a legitimação social, mas a 'inclusão'

\footnotetext{
${ }^{70}$ Este contexto do BNH se trata do momento (1964) em que o governo federal passa a tratar a habitação popular como um "problema fundamental" a ser resolvido e, para isso, confere ao recém-criado BNH a gestão do FGTS. Entre os objetivos listados nos documentos oficiais sobre o Banco estavam a coordenação da política habitacional e o financiamento para obras de saneamento, a difusão da propriedade residencial entre as classes de menor renda e também a eliminação de favelas. Constavam também o aumento e redistribuição de investimentos em vários setores da indústria (Bolaffi, 1975, p.50/51). Sem dúvida, os objetivos econômicos foram muito mais salientes, sobretudo após a década de 70. Considerando a operacionalização do BNH, Bolaffi (1975) mostra que o Banco, utilizando os recursos do FGTS, financia uma cadeia de atividades privadas que não chegaram perto de resolver o-falso - problema habitacional. Considerando os resultados, nas palavras de Bolaffi $(1975$, p. 55) "um processo industrial de favelamento".

${ }^{71}$ Azevedo (1988, p.110).

${ }^{72}$ Azevedo (1988) e Bolaffi (1975).
} 
de trabalhadores de forma massiva no sistema habitacional, que, sem subsídio, se mostra francamente um produto mercantil sem a função social conferida no período anterior"73 .

Nessa lógica, as Companhias de habitação deveriam desempenhar o mesmo papel dos incorporadores imobiliários, coordenando e supervisionando a produção de moradias $^{74}$ com o diferencial de possibilitar a redução dos preços das unidades residenciais já que as Cohabs eram remuneradas apenas por uma taxa administrativa paga pelo banco, tendo em vista que não lucrariam com a venda das unidades habitacionais ${ }^{75}$.

Entretanto, mesmo sem a lucratividade do incorporador, as medidas adotadas para garantir o retorno do banco e superar a inadimplência aumentaram as parcelas enquanto a tendência era o aumento de desemprego, os baixos reajustes salariais e uma especulação imobiliária crescente. Por isso, nesse segundo período, mesmo a "baixa classe média" ficou sem atendimento. Como alternativa para as classes de renda mais baixa, então, foram criados apenas financiamentos alternativos dos terrenos aliados à autoconstrução, porém estes só representaram cerca de $6 \%$ dos financiamentos viabilizados pelo $\mathrm{BNH}^{76}$.

Ainda sobre o financiamento federal para a produção de moradias, a passagem do Banco Nacional da Habitação para a Caixa Econômica Federal não mudou em termos do distanciamento da política urbana discutida nos órgãos como a Serfhau - Serviço Federal de Habitação e Urbanismo -, CNDU - Companhia de Desenvolvimento Urbano e Habitacional - e Ministério do Desenvolvimento Urbano. A Caixa é uma agência multilateral, em que o financiamento habitacional corresponde apenas a uma parte setorial do banco e, portanto "possui, como é natural, alguns paradigmas institucionais de um banco comercial, como a busca de equilíbrio financeiro, retorno do capital

\footnotetext{
${ }^{73}$ Negrelos (2014, p.606).

74 A produção era realizada por meio de licitação pública com um edital para projeto e obra, recorrentemente resultado da "racionalidade" implantada pelas construtoras para garantir lucratividade em cima do pagamento recebido e o interesse governamental em produzir o maior número de unidades (Negrelos, 2014).

${ }^{75}$ Azevedo (1988).

${ }^{76}$ Azevedo (1988).
} 
aplicado, etc.", o que limita ainda mais a atuação para atender as menores rendas que não dão retorno ${ }^{77}$. Mesmo com a passagem para a CEF, as Cohabs continuaram atuando como operadoras da política de habitação social, porém com escassos recursos federais.

A Companhia de Habitação de Londrina - Cohab-LD - foi criada em 1965, porém só começou a atuar efetivamente em 1970; neste intervalo ${ }^{78}$ a produção da habitação de interesse social em Londrina foi realizada pela Cohapar - Companhia de Habitação do Paraná - e pelo INOCOOP - Instituto de Orientação às Cooperativas ${ }^{79}$. Isto ocorreu devido à exigência de que todas as Companhias de Habitação criadas no Paraná deveriam estar vinculadas à Cohapar ${ }^{80}$.

Os ciclos de produção da Cohab-LD acompanharam as fases de ascensão e declínio do BNH. A maior produção concentrou-se na década de 70 com entregas de conjuntos que aconteceram no final da década de 70 e começo da década de 80 . Durante a década de 80 a produção caiu e a Cohab-LD entrou em declínio, principalmente devido ao endividamento da instituição ${ }^{81}$. Mesmo com a baixa da produção, a Cohab-LD continuou em funcionamento até hoje, com constantes ameaças de fechamento. Sobre a produção de conjuntos habitacionais, não cabe aqui recuperar todos os quantitativos de cada década ${ }^{82}$, como já fizeram vários pesquisadores ${ }^{83}$. Entretanto, recupero alguns dados para evidenciar uma primeira característica que vejo como fundamental na caracterização da habitação de interesse social a partir do modo

\footnotetext{
77 Azevedo (1988, p.118).

78 Nesta fase observa-se projetos urbanísticos mais elaborados e em terrenos menores, localizados próximos às áreas industriais, diferentemente das características predominantes dos projetos desenvolvidos pela Cohab-LD.

${ }^{79}$ Amorim (2015).

${ }^{80}$ Amorim (2011).

${ }^{81}$ Amorim (2011). Por meio dos dados de Fresca e Oliveira (2005), Amorim (2015, p.107) mostra esse declínio apresentando o quantitativo das entregas de conjuntos habitacionais construídos durante cada década:

Década de 70: 32 conjuntos (11.600 unidades, 443.811,77 $\mathrm{m}^{2}$ ) - 34,7\% do total implantado entre 1970 e 2000.

Década de 80: 40 conjuntos (11.326 unidades, $417.210 \mathrm{~m}^{2}$ ) - 43,7\% do total implantado entre 1970 e 2000. Década de 90: 20 conjuntos (4.122 unidades, $173.809 \mathrm{~m}^{2}$ ) - 21,7\% do total implantado entre 1970 e 2000.

82 Estes dados podem ser encontrados em Fresca e Oliveira (2005), Martins (2007), Prandini (2004), Cordeiro (2015).

${ }^{83}$ Fresca (2002); Bartlo (2015); Cordeiro (2015); Martins e Fresca (2005), Martins (2007), Prandini (2004).
} 
como tem operado a Cohab-LD no contexto londrinense: a de mercadoria política ${ }^{84}$. Mediações, acertos, negociações, que rompem - e muito - as fronteiras do legal e ilegal.

Sem dúvida, a produção de unidades habitacionais visa, acima de tudo, apaziguar o conflito iminente, sobretudo dos pobres com o Estado e setor privado ${ }^{85}$, mas uma outra dimensão importante é o poder de aglutinar votos em uma perspectiva clientelista que, em Londrina, por meio da Cohab-LD, foi possível fazê-lo favorecendo (ou parecendo favorecer) diferentes estratos sociais.

Considerando o recorte temporal entre as décadas de 1970 a $2000^{86}$, apesar de numerosa de um modo geral, a época farta de produção da Cohab-LD se concentrou durante a vigência do BNH. Durante a década de 70 a produção foi intensa. Nos primeiros anos, na administração de Dalton Paranaguá (MDB), quando a Cohab-LD se estruturou, ocorreu uma produção em diferentes regiões da cidade, sempre na periferia. A partir da primeira administração de Antônio Belinati ${ }^{87}$, a produção foi direcionada para a zona norte, muito afastada do centro, e aumentou significativamente o número de unidades produzidas. Esta administração durou até o começo da década de 80. De 1983 a 1988, a administração de Wilson Moreira (PMDB) - que já não teve um caráter tão populista como a gestão Belinati - sentiu a transição da gestão dos recursos para HIS do BNH para a Caixa Econômica Federal e caiu de forma significativa o número

\footnotetext{
${ }^{84}$ Misse (2010, p. 99) utiliza o conceito de mercadoria política para caracterizar essa "variedade de trocas e negociações ilícitas que correspondem, em grande parte, às representações sociais de 'corrupção', 'clientelismo', 'extorsão', 'tráfico de influência', 'fraudes econômicas' etc. (...), tenho insistido sobre a necessidade analítica de se abstrair a dimensão moral para compreender esses processos sociais como mais uma forma, não exclusivamente econômica, de mercado ilegal. A minha insistência, nesse caso, decorre da constatação de que se trata, quase sempre, de transações que lesionam mais a moral pública que a privada, que atingem mais o Estado do que o indivíduo, e que aspiram a alguma legitimidade particularista ou, ao menos em certos casos, encontram alguma justificação moral ou neutralização da culpa" (destaque no original). Com base no mesmo autor, para Telles e Hirata (2010, p.42), "as mercadorias políticas (...), compõem o modus operandi da gestão diferencial dos ilegalismos".

${ }^{85}$ Bolaffi (1975), sobre a criação do BNH.

${ }^{86}$ Período analisado por Martins (2007).

${ }^{87}$ Belinati foi eleito prefeito de Londrina pela primeira vez em 1976 pelo MDB. No final de 1979 entrou no PDS (antiga Arena) e em 1980 os mandatos foram prorrogados para mais dois anos. Em 1988 foi novamente eleito prefeito, nesse momento, pelo PDT. Voltou à prefeitura em 1996 (pelo PDT), mas logo após a posse foi para o PSB e, em 1999, para o PFL. Em junho de 2000 Belinati tem o mandato cassado e estava sem partido. Em 2008 foi novamente eleito prefeito, agora pelo PP, mas teve a candidatura impugnada. Marcelo Belinati, sobrinho de Antônio Belinati, é o atual prefeito de Londrina, eleito em 2016 pelo PP.
} 
de unidades construídas, porém ela ocorreu de forma mais dispersa pelas regiões da cidade. Depois desta gestão, Antônio Belinati foi novamente eleito, e voltou a investir na HIS sob a gestão da CEF, por isso a produção também foi reduzida.

Gráfico 1 - Dinâmica da produção de habitação de interesse social em Londrina, com a referência das administrações municipais e federais

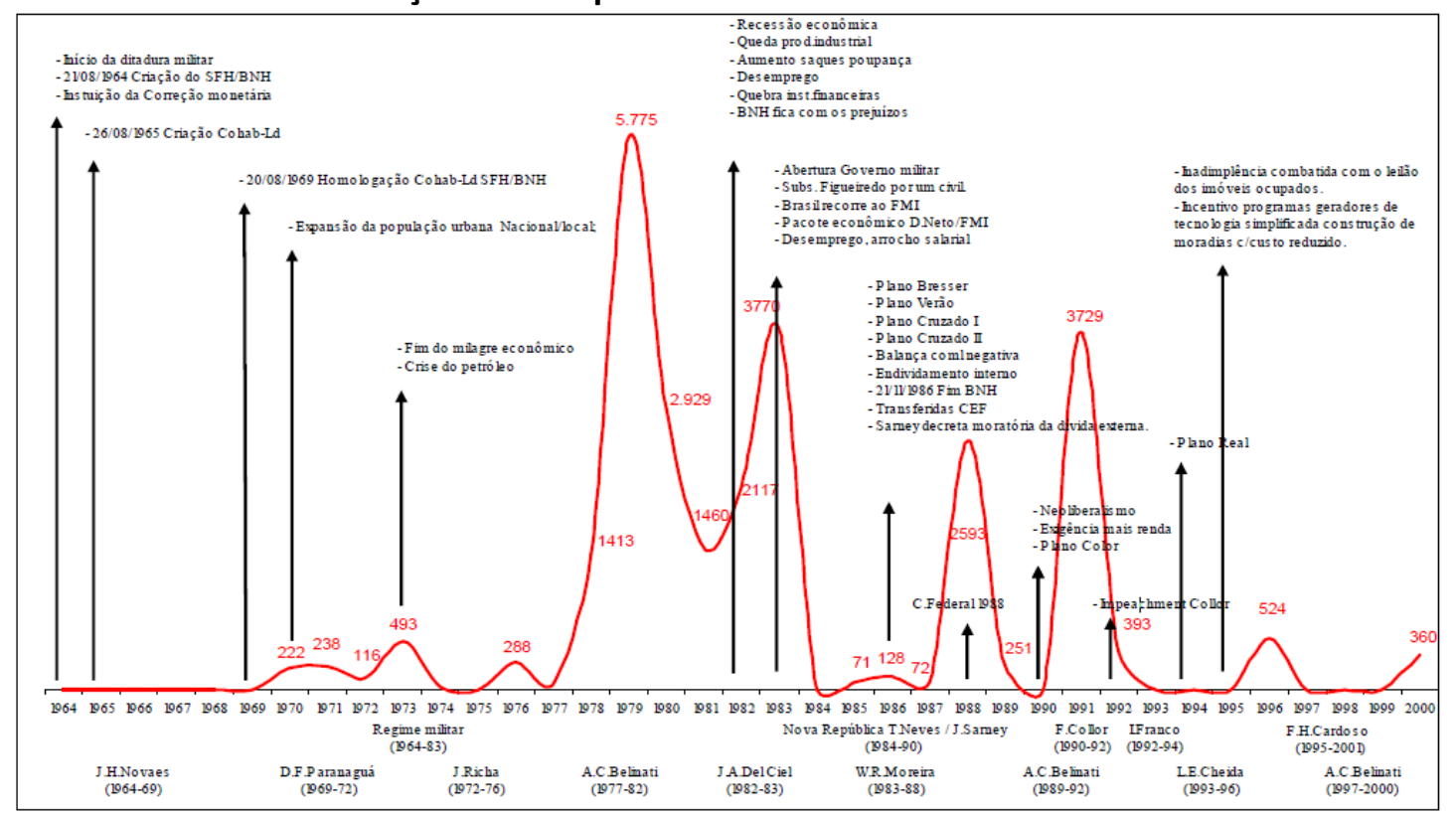

Fonte: Martins (2007).

Apesar da redução dos recursos disponibilizados pela CEF, a produção não foi tão reduzida, como mostra o gráfico 2 . Isto se deve aos primeiros anos de financiamento da Caixa na administração de Antônio Belinati que, só no ano de 1983, entregou 3.770 unidades ${ }^{88}$.

${ }^{88} \mathrm{Em} 1983$ foi o primeiro ano do mandato de Wilson Moreira (PMDB), mas as entregas dos conjuntos habitacionais correspondem às contratações da gestão Belinati. 
Gráfico 2 - Fonte dos recursos para produção da Cohab-LD entre 1970 e 2000

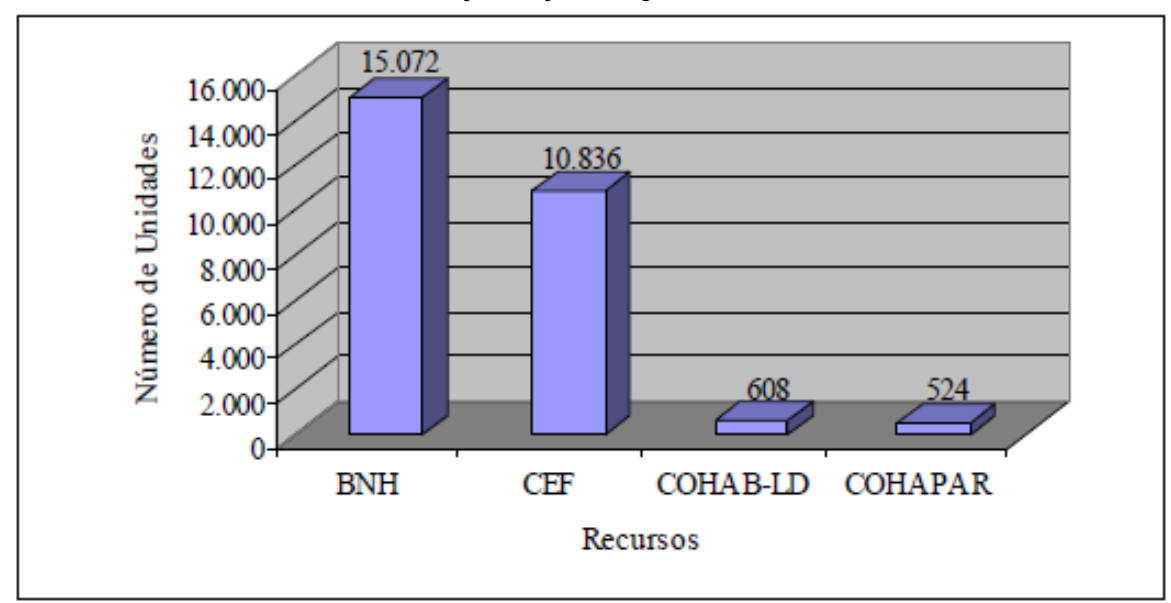

Fonte: Martins (2007).

Como fica nítido a partir dos quantitativos apresentados, a administração de Antônio Belinati se destaca na entrega de unidades habitacionais de interesse social. É assim que este político fortalece sua imagem na cidade, principalmente na periferia. Com certeza, essa estratégia surtiu efeitos considerando que, após sua primeira gestão de 1977 a 1982, ele se elegeu novamente em 1988, depois em 1997 (gestão em que tem seu mandato cassado) e em 2008, porém nesta última, apesar de vencer a eleição, não pôde assumir pois teve sua candidatura impugnada. Na última eleição para prefeitura de Londrina (2016) seu sobrinho Marcelo Belinati Martins (PP), devido ao capital político do nome da família, foi eleito. 
Gráfico 3 - Unidades residenciais produzidas nas gestões municipais entre 1970 a 2000.

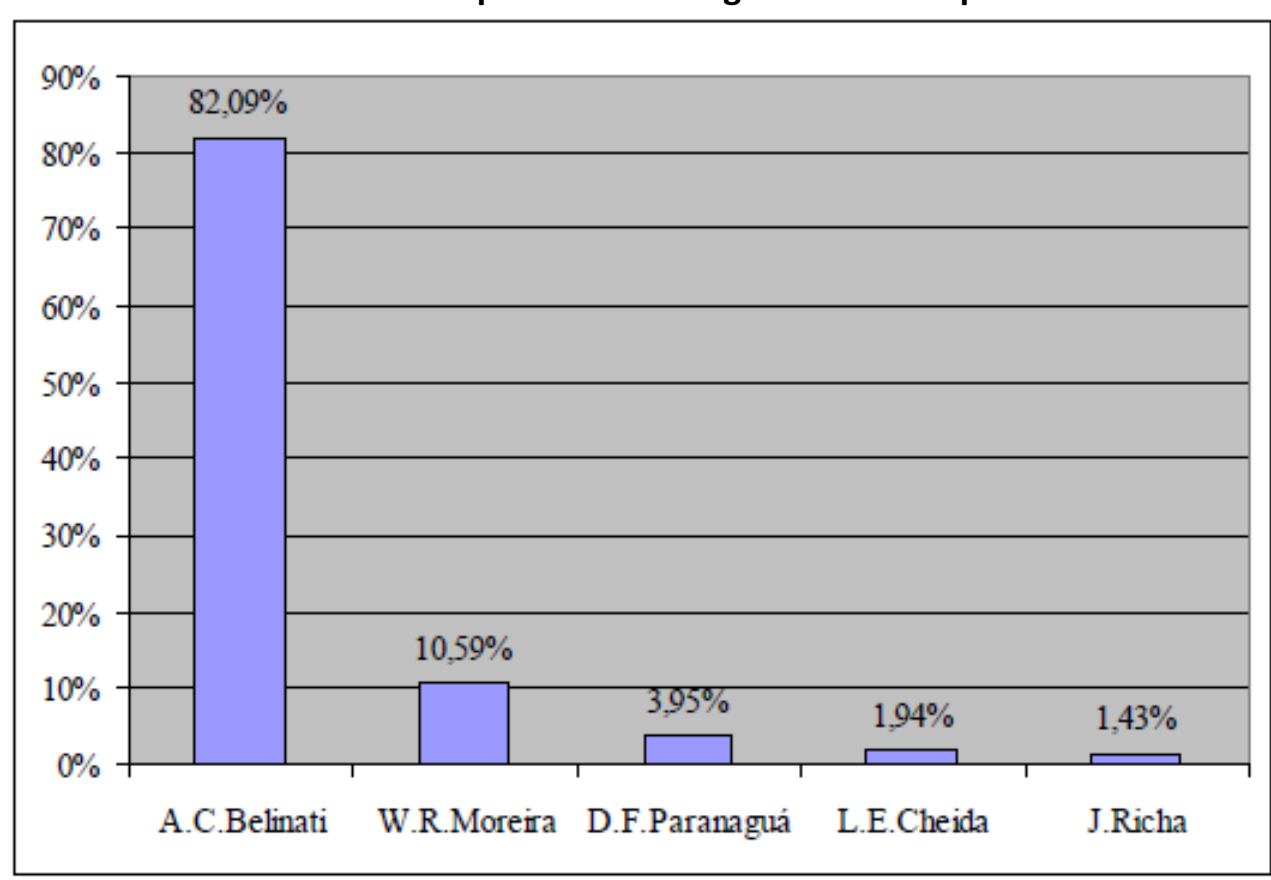

Fonte: Martins (2007). 
Figura 9 - Localização dos CHIS 1970-2000

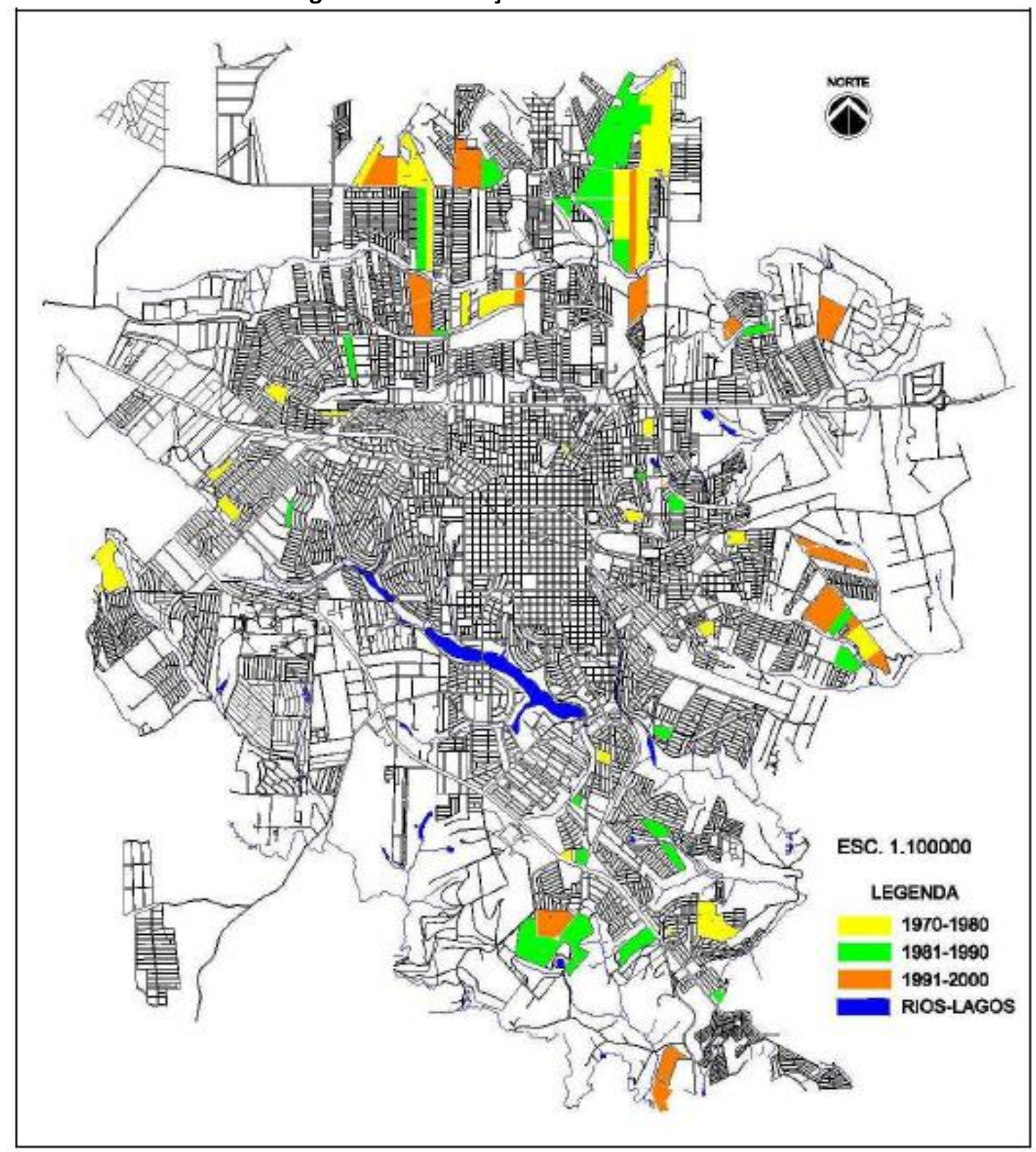

Fonte: Martins (2007).

Lembrando que apenas parte da produção do BNH e da CEF atendeu realmente à baixa renda. Por isso, neste mesmo período de intensa produção habitacional aumentaram também as ocupações irregulares, na década de 70 e 80, o que resultou em outro quadro da precariedade habitacional em Londrina e se agravou ao longo dos anos. 
A dinâmica da década de 90 é importante pois é quando cessaram os recursos para HIS do governo federal, e a Caixa passou a cobrar valores e parcelas mais altas que dificultaram ainda mais a inclusão da população de baixa renda nos programas habitacionais. Ainda, as medidas liberais do Governo Federal criaram condições ainda mais difíceis para essa população, com os altos índices de desemprego e os baixos salários. Com isso, e sem controle local sobre o mercado imobiliário, o número de favelas aumentou exponencialmente. Por outro lado, também no contexto local, três administrações que afirmavam voltarem seus esforços para a população de baixa renda/classe trabalhadora acontecem em sequência. Por isso, mesmo com a baixa da produção de conjuntos habitacionais, que desde o final da década de 80 já não atendiam a população de baixa renda, observamos em Londrina uma atuação do poder público relativamente significativa nessas áreas de moradia precária.

Durante a década de 90 ocorreram duas administrações distintas: Antônio Belinati (PP) e Luiz Eduardo Cheida (PT). Belinati exerceu duas administrações (19891992 e 1997-2000) e, entre elas, houve uma administração petista (1993-1996). Devido à baixa de recursos para HIS e dado o viés dos dois perfis de administração pública, a atuação quanto à política habitacional mudou de perspectiva. Interessante observar neste período a tentativa de "negar" a administração anterior com relação à criação do Fundo Municipal da Habitação que foi criado e extinto entre as duas administrações (criado pela Lei Municipal no 5526/1993 e extinto pela Lei Municipal no 7153/1997).

\section{O pretexto do desfavelamento e a origem dos assentamentos}

Na década de 90, com a queda dos investimentos federais em habitação social e a incapacidade econômica da Cohab-LD de viabilizar novos empreendimentos, a administração de caráter populista que se sustentava com as negociações dos conjuntos habitacionais da Cohab-LD se reinventou e passou a remover as famílias de fundos de vale para assentamentos em terrenos da Cohab-LD com características muito semelhantes às das favelas, sem infraestrutura e equipamentos, e barracos precários. 
Apesar do discurso do desfavelamento normalmente estar associado à remoção de famílias residentes em favelas para conjuntos habitacionais, sobretudo durante a vigência dos financiamentos do $\mathrm{BNH}$, em Londrina foram poucos os conjuntos habitacionais construídos com este objetivo.

Tabela 2 - Unidades habitacionais destinadas ao desfavelamento em Londrina entre 1970 e 1991

\begin{tabular}{l|c|c|c|l}
\hline \multicolumn{1}{c|}{$\begin{array}{c}\text { Nome dos } \\
\text { Conjuntos } \\
\text { Habitacionais }\end{array}$} & $\begin{array}{c}\text { Ano de } \\
\text { entrega }\end{array}$ & $\begin{array}{c}\text { Total de } \\
\text { unidlades }\end{array}$ & $\begin{array}{c}\text { Número de } \\
\text { unidades } \\
\text { destinadas ao } \\
\text { desfavelamento }\end{array}$ & Localização \\
\hline Barra Vento & 1971 & 34 & 34 & Vila Portuguesa \\
\hline Pindorama I & 1972 & 116 & 116 & Vila Fraternidade \\
\hline Pindorama II & 1976 & 53 & 53 & Vila Fraternidade \\
\hline Novo Amparo & 1980 & 369 & 369 & Atrás da EPESML \\
\hline Santiago I & 1988 & 38 & 38 & Procedentes da Favela Vila Rica \\
\hline José Belinati & 1991 & 133 & 90 & Entre o CH João Paz e CH Semiramis \\
\hline
\end{tabular}

Fonte: Martins (2007).

Por outro lado, surgiram os assentamentos promovidos pela Cohab-LD.

(...) o termo 'assentamentos urbanos' foi criado pelo, então prefeito, Antônio Casemiro Belinati, como uma forma de conquistar votos da população assentada, pois, eram apenas retiradas as famílias das áreas consideradas ilegais de ocupação, ou que estavam sendo reclamadas judicialmente por seus proprietários, e levadas para estas áreas concedidas pela Prefeitura Municipal, sem qualquer infra-estrutura, possuindo as características semelhantes as das favelas, mas a população assentada acreditava estar melhorando de vida. ${ }^{89}$

Devido a esse uso da habitação social como forma de promover os políticos, Melchior e Asari (2003, p.546) argumentam que as migrações campo-cidade e de cidades

\footnotetext{
89 Silva e Melchior (2002). Com a criação dos Assentamentos, a Cohab-LD passou a diferenciar nos documentos oficiais: Assentamentos precários: "assentamentos" de famílias (famílias que são assentadas pela Cohab-LD) removidas de outras ocupações para áreas da Cohab-LD ou que serão negociadas pela Cohab-LD para moradia desta população. Essas áreas não possuem infraestrutura urbana e, por isso são denominados "precários; Ocupações irregulares: áreas públicas ou particulares que foram ocupadas por famílias de baixa renda sem o auxílio da Cohab-LD. Para fins de regularização fundiária apenas os assentamentos precários podem ser regularizados.
} 
menores da região para Londrina foram intensificadas pela crença de que em Londrina o poder público municipal dava garantias para a aquisição de um terreno próprio ou de uma unidade habitacional.

De todos os assentamentos estudados pelas autoras, (João Turquino, São Jorge, União da Vitória e Santa Fé), foi observado um padrão de deslocamento das famílias. Grande parte saiu do campo - decorrente da mecanização, substituição da mão de obra por maquinário - migrou para cidades menores e depois para Londrina, ou direto para Londrina. Dentro de Londrina começaram no aluguel, mas a progressão do aluguel e a instabilidade dos empregos e os baixos salários levaram, após morarem em diferentes bairros em busca de aluguéis mais baratos, às ocupações e/ou assentamentos.

O levantamento de 2003 mostra que a maioria (supera os 60\%) dos moradores dos assentamentos teve origem na zona rural, fato que decorre do perfil econômico da região norte do Paraná e da permanência das atividades agropecuárias, e com índices de industrialização medianos. Ao serem direcionados para os assentamentos, as famílias passavam a pagar a prestação para a Cohab-LD, mesmo sem nenhuma infraestrutura no bairro, como redes de água, luz e de esgoto. Portanto, tratava-se de uma transferência da favela, mas com a possibilidade de compra.

As autoras argumentam que quanto mais promoveram o reassentamento, mais populares os governantes ficaram. No momento da pesquisa constataram a alta popularidade do prefeito Antônio Belinati, reconhecido pelo programa de bases populistas.

Já durante o governo de Cheida (1993-1996) foram realizadas obras de urbanização $^{90}$ em vários assentamentos precários que foram removidos na gestão

\footnotetext{
90 Foram realizados dois programas em sequência: O Programa Morar Melhor (1993-1996) visava promover a urbanização de favelas e a regularização fundiária para população com renda inferior a três salários mínimos, residentes de favelas e assentamentos precários. Atendeu um total de 4.608 famílias. Também foram entregues "kits" de materiais de construção (tábua, prego e telha) para a construção de um módulo $3 \times 3 \mathrm{~m}$, em terrenos dotados de infraestrutura. A urbanização das favelas procurava manter o maior número de famílias no local, sempre que possível, exceto quando as áreas eram consideradas inadequadas, de risco ou de fundo de vales. O lote mínimo para este Programa possuía 120,00m², com 8,00 metros de frente e 15,00 metros de profundidade. O programa foi criticado com o argumento de que como a urbanização ocorria no local da ocupação original, legitimou as ocupações em locais considerados inadequados como praças, por exemplo. Como foi descrito, em entrevistas foram relatados os acordos
} 
anterior. O investimento de maior peso da administração petista foi na área de saneamento. As obras de urbanização também geraram remoções e novamente houve uma série de deslocamentos populacionais. Foi nesta administração que foi realizado o primeiro levantamento oficial da situação habitacional de Londrina ${ }^{91}$.

Nesta administração a lógica da mercadoria política se mantém por meio de acordos entre a gestão da Cohab-LD e movimentos sociais de moradia. A Cohab-LD fornecia informações sobre a localização dos terrenos da Companhia para os movimentos organizarem ocupações planejadas de um modo em que a Cohab-LD conseguia viabilizar a regularização das áreas ${ }^{92}$. Com o intervalo da gestão do Belinati até 2000, o então Presidente da Cohab-LD na gestão Cheida - Nedson Micheleti - foi eleito prefeito e um dos diretores - André Vargas - foi eleito vereador em 2000, deputado estadual em 2002 e deputado federal em $2006^{93}$.

Na gestão Belinati de 1997 a 2000 - gestão em que foi cassado - foi criado o projeto Renascer com o objetivo de implementar uma política habitacional no município. O projeto era constituído por programas $^{94}$ que visavam levantar recursos financeiros pelas famílias inscritas no programa no modelo de poupança e firmando parcerias com o setor privado (principalmente construtoras).

O interesse político sobre essas áreas está pautado na cessão de favores que têm um custo financeiro baixo e atinge grande número de pessoas que incorporam o jogo político configurando uma relação de reciprocidade, de cumplicidade ${ }^{95}$.

entre a Cohab-LD e os movimentos sociais neste período; o Programa Vida Melhor (1995-1999), que depois passou a se chamar Habitar Londrina (possivelmente como forma de desvincular da gestão anterior) consistia no fomento à construção de novas unidade habitacionais em parceria com a iniciativa privada. Destinava-se a famílias com renda de três a dez salários mínimos (PEMAS, 2002).

91 O Documento resultante deste levantamento consiste em IPPUL (1996).

92 Informações obtidas a partir de entrevistas com diferentes funcionários de carreira e cargos administrativos da Cohab-LD.

${ }^{93}$ Foi preso em 2015 devido ao envolvimento nos escândalos de corrupção na chamada “Operação LavaJato", e cumpre a pena em condicional desde 2018.

${ }^{94}$ O principal programa foi o Poupalar (1998-2000), em que a Cohab-LD realizava para o interessado a abertura de uma caderneta de poupança na Caixa Econômica Federal, sem comprovação de renda, orientando que poupasse $10 \%$ de sua renda para aquisição da habitação. No caso de desistência a poupança era resgatada mediante a retenção de uma "taxa de desistência" (PEMAS, 2002).

${ }^{95}$ Valladares (1978, p.27). 


\section{Visão empresarial e propriedade imobiliária}

Outro aspecto do modo de operar da Cohab-LD é a visão empresarial ${ }^{96}$ sobre o cumprimento de suas funções. Tal visão empresarial me soava contraditória pensando no papel da empresa pública e na moradia como um direito fundamental e considerando o atendimento de uma demanda que não é solvável. Entretanto, resgatando o Estatuto Social, a legislação e o histórico da criação da empresa, como já comentado, percebi que na sua origem traz uma função empresarial e mercadológica e que absorveu - aí sim de forma contraditória - outras funções no âmbito da assistência social. Isso confere sentido às palavras de Heleno Rabello ${ }^{97}$ sobre a situação das ocupações irregulares:

O problema é social e esta não é a função da Cohab. A nossa função é construir casas. Só que, ao longo dos anos, foram transferindo esta responsabilidade para nós por estar ligada à questão da habitação. Com isso, desvirtuaram o nosso papel. A Cohab hoje, endividada, não consegue nem construir casas, nem resolver o problema das favelas.

Nesse sentido, a crise quase existencial pela qual passa a Companhia, relatada no dia a dia dos funcionários e diretores, por outros setores da administração pública e pela população, é decorrente dessa incapacidade de solucionar os problemas relativos à habitação a que se propõe (de fato, de maneira descabida e até ingênua), com excesso de burocracia e lentidão, junto a processos de reintegração de posse conflituosos e violentos, e sem conseguir recuperar os investimentos na venda de unidades habitacionais, sendo assim caminha no sentido contrário ao da eficiência, produtividade e agilidade, tão valorizadas pelos princípios empresariais.

\footnotetext{
96 Não podemos colocar nos mesmos termos que a tese de Pulhez (2014) sobre a gestão empresarial terceirizada empreendida pela CDHU. Aqui trago a visão empresarial como lógica (Laval e Dardot, 2013) que permeia a visão e as práticas da Companhia na administração de capital e de terras, na abordagem e negociações com ocupações irregulares e no diálogo com a população atendida ou, nos termos da Companhia, com seus clientes.

${ }^{97}$ Heleno Rabello é funcionário de carreira do setor social da Cohab-LD e hoje exerce o cargo de diretor técnico da Companhia. Esta fala é parte de entrevista concedida ao jornal Folha de Londrina em 2001. Disponível em: https://www.folhadelondrina.com.br/reportagem/favelas-concentram-carentes-desde1966-341194.html. Acesso em: 29/10/2019.
} 
Em termos de receita, no momento de criação, foi destinado à Cohab-LD um capital social de $\mathrm{Cr} \$ 100.000 .000$ (cem milhões de cruzeiros) conforme o artigo 20 da Lei Municipal no 1.008 de 1965. De acordo com o Estatuto Social (Art. 6)), o Capital Social é

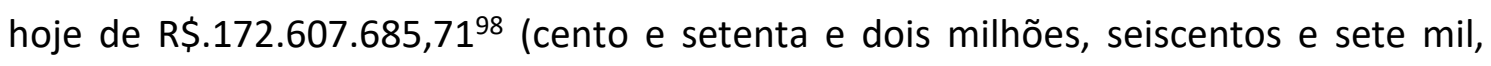
seiscentos e oitenta e cinco reais e setenta e um centavos).

Assim como no restante do Brasil, quando a Cohab-LD foi criada, foram adquiridas terras para viabilizar a produção de moradias. Em todo o país foi dado início à

formação de 'bancos de terras públicas', principalmente grandes glebas, muitas vezes ainda rurais, nas periferias das grandes cidades, para a produção de megaconjuntos habitacionais (...) construídos com os chamados 'projetos-padrão' no esquema terraplanagem+unidade mínima, enquadrando o empreendimento no padrão de maior retorno financeiro ${ }^{99}$.

O primeiro diretor, responsável pela aquisição desses terrenos era um agropecuarista local ${ }^{100}$. As propriedades adquiridas eram glebas rurais, algumas delas negociadas devido à queda da produção do café. O principal argumento era de que essas propriedades eram mais baratas e, em Londrina, esse período corresponde de fato à decadência da produção na região devido às geadas que impactaram severamente as propriedades.

É relevante o fato de que a Cohab-LD adquire as glebas pois investe parte do seu capital social no mercado imobiliário. A partir desse momento, a relação entre a CohabLD e a propriedade imobiliária deixa de ser apenas de incorporadora e passa a ser também de proprietária de terras ${ }^{101}$.

\footnotetext{
98 O valor do Capital Social da Cohab-LD apresentado no Estatuto Social disponível no site corresponde ao aumento aprovado em 2016.

${ }^{99}$ Negrelos (2014, p.60).

100 Cordeiro (2015).

${ }^{101}$ Sobre o papel do proprietário na produção habitacional, Maricato (2009, p.41) coloca que "a moradia é uma mercadoria especial. Além do capital de construção, o processo produtivo inclui um financiamento ao consumo (habitação é um dos bens mais caros de consumo privado e como uma mercadoria especial exige um financiamento específico), um capital de incorporação e um agente especial - o proprietário de
} 
A compra das propriedades não foi, até hoje, analisada com profundidade, mas determinados fatos mostram que algumas negociações foram, no mínimo, duvidosas. A relação com o mercado imobiliário, principalmente sobre os vazios urbanos deixados para fins de valorização imobiliária já foi apontada por alguns autores ${ }^{102}$, mas vou utilizar aqui duas situações distintas para ilustrar como algumas dessas negociações caracterizam uma "zona de indistinção" em que fica difícil distinguir a legalidade da ilegalidade, o público e o privado ${ }^{103}$. O que se supõe aqui é que a companhia foi utilizada como meio na articulação entre poder público municipal e proprietários de terras ${ }^{104}$.

A primeira delas corresponde à compra das terras da Fazenda Refúgio em 1991, durante a gestão de Antônio Belinati. A propriedade comprada possui restrições ambientais $^{105}$ e físicas sendo inadequada para ocupação, muito menos para a construção de seis mil unidades habitacionais conforme anunciado na época da compra. Além da inadequação para moradia, o que levou à ação judicial foi a suspeita de que a compra foi superfaturada. Na época, a Cohab-LD pagou o equivalente a mais de um milhão de dólares (Cr\$ 943,8 milhões) à Dinardi Agropecuária ${ }^{106}$ e devido aos laudos que comprovaram que a propriedade não valia nem metade disso resultou em ações na esfera civil e inquérito policial.

Outra situação é a indenização paga à proprietária do terreno que se encontra em fase de regularização fundiária. Este terreno está ocupado desde 1988, quando a Cohab-LD removeu famílias para obras de urbanização em outro bairro e as assentou na área. Entretanto, possivelmente por problemas relacionados a certidões de débito o imóvel, a Cohab-LD não conseguiu registrar o terreno e formalizar a desapropriação em

terra - de quem depende uma condição básica para produção. Cada novo empreendimento exige que uma nova parcela de terreno seja assegurada."

102 IPPUL (1996); Bartlo (2015); Cordeiro (2015).

${ }^{103}$ Agambem (2004).

${ }^{104}$ Este não seria um caso isolado de Londrina, sem dúvida. Bolaffi $(1975$, p. 54) discute algumas dessas "burlas" realizadas com os recursos do banco.

105 Até 2008, a Cohab-LD tinha sido multada seis vezes pelo Instituto Ambiental do Paraná - IAP pela retirada de vegetação e terra, pela supressão de área de preservação permanente e por permitir a realização de rallys ilegais. Informações obtidas em reportagem da Folha de Londrina, disponível em: https://www.folhadelondrina.com.br/cidades/fazenda-refugio-terra-de-ninguem-645048.html. Acesso em: 29/10/2019.

106 O dono da Dinardi Agropecuária na época, Maurício Dinardi, é também proprietário da Dinardi Engenharia, uma das principais construtoras de Londrina. 
1988, que só foi possível em 2014 sob a vigência da Lei Federal no 11.977/2009107. Essa área era de propriedade de um diretor da Cohab-LD, e mesmo passados mais de 20 anos da ocupação na área, a desapropriação foi paga à viúva do antigo proprietário.

Seguindo a lógica imobiliária, a Cohab-LD ainda mantém um banco de terrenos desocupados cedidos ou alugados, se beneficiando da especulação imobiliária. 0 argumento é o de onde está investido o capital da empresa e, por isso, a regularização fundiária das ocupações e assentamentos irregulares em terrenos da Cohab-LD é vista como descapitalização pelos setores administrativos da Companhia. Deve ser por esse motivo que há casos em que a Cohab-LD optou pelo pedido de reintegração de posse contra ocupantes de seus terrenos no lugar de promover a regularização fundiária.

Outra prática que se repete marcando esse modus operandi abordado aqui é quanto à mediação de conflitos fundiários entre ocupantes e proprietários. Tendo em vista que as ocupações irregulares se tornaram matéria da Cohab-LD, esta é acionada em situações de conflito seja para tentativas de negociação ou para auxiliar a polícia na remoção das famílias nos casos de reintegração de posse. Quando se trata de uma mediação anterior a um pedido de reintegração de posse, por exemplo buscando acordo com o proprietário, pelos relatos, documentos e reportagens, é evidente o favorecimento dos proprietários. A questão mais latente é a ausência dos pressupostos dos instrumentos da Usucapião. A principal atitude recorrentemente adotada pela Cohab-LD é a compra ou desapropriação pelo município das áreas ocupadas, mesmo quando a situação se enquadra nos termos da Usucapião. Observa-se, assim, que o pensamento proprietário vigora mesmo quando isso gera um ônus desnecessário à Companhia.

O primeiro fato sobre isso teve início logo nos primeiros anos dos trabalhos da Cohab-LD, durante a década de 70. Na segunda gestão, mas logo que foram abertas as instalações, foi dada a reintegração de posse para a Caixa Econômica Federal de uma

\footnotetext{
107 Só em 2014, com as facilidades da Lei Federal no 11.977/2009 é que foi possível registrar o formal de partilha da área e transferir para a Cohab-LD. Toda a documentação estava descrita nos autos como emissão de posse por ser resultado de desapropriação, mas a emissão foi cancelada devido às mudanças promovidas pela Lei Federal no 11.977/2009 que permite a transferência direta para o nome da CohabLD.
} 
área ocupada irregularmente chamada de Favela da Caixa Econômica. A ação policial estava montada e 400 famílias seriam despejadas da área e a prefeitura não tinha uma solução para apresentar. Então, o Presidente da Cohab-LD - Nelson Gavetti - negociou pessoalmente com a Caixa Econômica o terreno por um "valor simbólico" mantendo a população no local ${ }^{108}$.

A partir desse fato, sempre nesses termos, a Cohab-LD passa a mediar e negociar com proprietários e ocupantes. No entanto, nem sempre - como visto no caso da Fazenda Refúgio - trata-se apenas de um valor "simbólico". Outro exemplo, também da década de 90, foi a compra da área do Jd. Maracanã, que se encontra em fase de regularização fundiária. Tratava-se de uma ocupação de mais de 400 famílias. A área havia sido avaliada em $\mathrm{R} \$ 136 \mathrm{mil}$, mas foi pago $\mathrm{R} \$ 200$ mil pelo terreno. A loteadora que era proprietária da área havia pedido $\mathrm{R} \$ 280$ mil no início das negociações ${ }^{109}$.

Uma reportagem de 2006 - gestão de Nedson Micheleti (PT) - sobre uma ocupação em um terreno particular na zona norte de Londrina (no CH Vivi Xavier) mostra como a ação da Cohab-LD nessa mediação/negociação é percebida pela população: “De acordo com o presidente da Associação de Moradores da invasão ${ }^{110}$, Ailton Natalino da Silva Souza, a esperança dos moradores é de que a companhia compre o terreno e repasse a área por meio de um financiamento ${ }^{111}$." No entanto, com uma postura menos política, a Cohab-LD se negou a fazer a mediação neste caso:

(...) em uma reunião realizada na Cohab, representantes da associação ouviram do próprio presidente da companhia que a possibilidade de desapropriação está descartada. 'Eles pediam uma posição da Cohab, e nossa posição é essa. Essas famílias terão de fazer suas inscrições na fila de financiamento e aguardar. Não podemos deixar 14 mil famílias

\footnotetext{
108 O relato desse evento encontra-se em Gavetti (1998, p.47 e 48).

109 Folha de Londrina (1999). Disponível em: https://www.folhadelondrina.com.br/cidades/cohabcompra-terreno-invadido-235181.html. Acesso em: 29/10/2019. Nesta reportagem o presidente da associação de moradores do Jd. Maracanã diz ter ficado satisfeito com a compra pela Cohab-LD. Portanto, foi uma solução para o conflito que pareceu agradar a todas as partes o que, em termos políticos, tem um valor bastante alto.

110 O termo "invasão" foi usado na fala original. Cabe o destaque de que o uso do termo criminaliza o ato, tendo em vista que invadir é um crime, diferentemente do uso do termo "ocupar".

111 Folha de Londrina (2006). Disponível em: https://www.folhadelondrina.com.br/geral/familiasurbanizam-terreno-invadido-555173.html. Acesso em: 01/05/2019.
} 
de lado e privilegiar uma ocupação'. (...) A liderança da ocupação deve nos próximos dias se reunir com o proprietário do terreno e discutir algumas alternativas ventiladas durante o encontro de ontem à tarde. Afonseca não quis adiantar o conteúdo da conversa. 'A Cohab não pode fazer nada. $O$ problema tem de ser revolvido entre os invasores e o dono do terreno', afirmou.

Essa afirmação do presidente da Cohab-LD na época "não podemos deixar 14 mil famílias de lado e privilegiar uma ocupação" tem um sentido disciplinador ${ }^{112}$ muito relevante que observei em negociações recentes entre a Cohab-LD e membros de ocupação. Durante as entrevistas na Cohab-LD vários profissionais de diferentes áreas relataram acreditar que muitas ocupações não ocorrem devido a uma situação de emergência das famílias, mas que são apenas uma forma de pressionar a Cohab-LD para "passar aquelas famílias na frente da fila do atendimento". Primeiro que a ideia de "fila" é ilusória, pois não existe um atendimento em ordem, são realizados sorteios entre as famílias cadastradas, portanto não existe garantia no atendimento. Porém, ao dar declarações que a Companhia se posiciona contra o privilégio dos ocupantes, a CohabLD coloca as famílias que estão aguardando contra as ocupações, reduzindo a força política, isolando e criminalizando o ato.

\section{Novas perspectivas: Ministério das Cidades e a Política Nacional da Habitação}

Em âmbito federal a década de 2000 representou importante avanço na regulamentação do capítulo da Política Urbana da Constituição Federal de 1988 (Art. 182 e Art. 183) pela Lei Federal no 10.257/2001 - Estatuto da Cidade - que também criou, com relação à política habitacional, o instrumento das Zonas Especiais de

\footnotetext{
${ }^{112}$ A referência de disciplina utilizada aqui é de Foucault (2014). No entanto, o mesmo autor ensina que nem sempre o dispositivo vai ter o resultado esperado, tendo em vista que não é um plano pré-concebido. Pela fala do presidente da associação de moradores do bairro, acredito que, nesse caso, a atitude da Cohab-LD de frequentemente buscar a solução para o conflito de antemão levou à organização desses sujeitos para a ocupação, visando a solução futura. Nos termos de Foucault, o dispositivo criou o sujeito. Isto será explorado mais adiante.
} 
Interesse Social - ZEIS 113 - e uma série de outros instrumentos de combate à especulação imobiliária. Depois, a eleição do presidente Luiz Inácio Lula da Silva, a criação do Ministério das Cidades e a elaboração do Plano Nacional da Habitação (PLANHAB) foram os indicativos de que seria o início de um novo ciclo para a política urbana e para a política habitacional.

Cardoso e Aragão (2013) constroem um panorama do percurso do Projeto Moradia do então candidato à presidência Luís Inácio Lula da Silva e como essa concepção pautou a estruturação do Sistema Nacional de Habitação no âmbito do Ministério das Cidades. O projeto previa a criação de conselhos para garantir a participação popular, a criação do Fundo Nacional da Habitação, o financiamento habitacional para a população de baixa renda, articulação entre a política habitacional e as estratégias de controle da retenção especulativa do solo, entre outros aspectos.

Os autores afirmam que a eleição de Lula à presidência representou a consolidação da possibilidade de implantação do Projeto Moradia e, portanto, de importantes conquistas por parte do Movimento pela Reforma Urbana. Isso se fortaleceu com a efetiva criação do Ministério das Cidades, com composição de membros do movimento, e a criação da "Secretaria Nacional de Habitação, [que] ao longo do ano de 2003, desenvolveu as bases normativas e institucionais da política de habitação, propondo a estruturação do Sistema Nacional de Habitação (...)"114.

A Lei Federal no 11.124/2005 que regulamenta o Fundo Nacional da Habitação de Interesse Social - FNHIS - também consiste em importante avanço no que se refere ao aporte de recursos destinados às políticas habitacionais e foi elaborada em consonância com o projeto de iniciativa popular do Movimento pela Reforma Urbana. Desde a criação do fundo, os municípios receberam este recurso para diferentes

\footnotetext{
${ }^{113}$ Segundo o Guia para Implementação do Estatuto da Cidade (Brasil, 2002), o instrumento das ZEIS visa a regularização fundiária de assentamentos informais e a produção de habitação de interesse social em áreas bem localizadas da cidade. Além disso, as zonas especiais recebem esse nome por ser uma categoria de zoneamento demarcada em áreas de assentamentos irregulares ou em áreas vazias em que, reconhecendo as características da ocupação nessas áreas e os limites quanto à urbanização, ficam permitidos parâmetros legais de ocupação mais flexíveis em relação aos parâmetros exigidos na lei de zoneamento convencional.

${ }^{114}$ Cardoso e Aragão (2013, p.29).
} 
programas habitacionais, inclusive para promover a regularização fundiária. Os editais dos recursos continham premissas importantes para garantir o interesse social das propostas, como a comprovação da finalização dos procedimentos de regularização para a prestação de contas dos programas.

A criação do Ministério das Cidades em 2003 contou com uma composição com membros do Movimento pela Reforma Urbana, e deu sequência à estruturação da Secretaria Nacional da Habitação que, dentro de seus desmembramentos, havia se tornado o órgão responsável pela realização de uma Política Nacional da Habitação.

Nesse período também foram abertos editais para financiamento de programas de combate à pobreza pelo BID - Banco Interamericano de Desenvolvimento. Seguindo a lógica da política pró poor no Banco Mundial em novas agendas de reestruturação econômica, as abordagens dos relatórios de 1987 e 1993, este último elaborado em conjunto pelo BID e PNUD, vão defender o financiamento de programas de combate à pobreza, principalmente nos países periféricos. Os programas deveriam contemplar tanto a produção de dados sobre a situação da pobreza nas diferentes localidades, já que a precisão dos programas deveria responder às demandas locais sem seguir uma padronização rígida ${ }^{115}$.

De 2000 a 2009 ocorreram duas gestões petistas em sequência decorrente da reeleição de Nedson Micheleti $(\mathrm{PT})^{116}$. Durante este período são contratados novos programas de financiamento para a política habitacional como reflexo de uma nova

\footnotetext{
115 Maranhão (2009). Segundo Maranhão (2009, p. 74) a agenda do combate à pobreza é incorporada no discurso do BM no final da década de 90 alinhado ao Relatório sobre Desenvolvimento Mundial de 2000 e 2001 (Attacking the Poverty). Sendo impossível de ignorar os efeitos da primeira geração de reformas nos países subdesenvolvidos, "na interface entre as agendas do ajuste estrutural e da governança", foi construída a estratégia de combate à pobreza e "mobilizada como um dispositivo capaz de adaptar a liberalização dos mercados e dos fluxos de capital à dimensão humana e participativa reivindicada pelas forças políticas mais à esquerda". Nesse sentido, "a retomada da conexão entre segurança e pobreza foi a maneira pela qual a contenção dos distúrbios sociais foi formulada no cálculo estratégico do Banco Mundial" (Maranhão, 2009, p.76). Influenciado pela teoria de Amartya Sen, o desenvolvimento passa a ser defendido não apenas como uma mensuração do crescimento econômico, mas a partir da melhora na qualidade de vida das pessoas que não depende apenas da renda per capita. Para ele o desenvolvimento consiste no "enriquecimento da vida" (Maranhão, 2009, p.85). Nessa lógica o combate à pobreza aparece como a "necessidade de intervir nas variáveis presentes no meio" (Maranhão, 2009, p.88).

${ }^{116}$ Diretor da Cohab-LD entre 1992 e 1996, durante a gestão Cheida (PT).
} 
proposta após a criação do Ministério das cidades. Neste período, alguns programas são financiados pelo Banco Interamericano de Desenvolvimento - BID.

$\mathrm{Na}$ década de 2000, os assentamentos precários estavam localizados principalmente na expansão da área urbana à norte e à leste. A maior parte das ocupações desse período encontra-se em processo de regularização fundiária (2015) e passaram por ações de urbanização durante a década de 2000. Em 2000 e 2001 foram entregues os empreendimentos do Programa Poupalar. Em 2002 foram lançados o Programa de Arrendamento Residencial - $\mathrm{PAR}^{117}$ - (focado na população com renda de 3 a 6 salários mínimos), e o Programa Habitar Brasil - BID (HBB) ${ }^{118}$. Como condição para acesso ao recurso do Programa HBB, foi desenvolvido o Plano Municipal de Assentamentos Subnormais (PEMAS) e o Subprograma de Desenvolvimento Institucional (PI). Outros empreendimentos foram produzidos via recursos da Caixa Econômica Federal e com recursos próprios da COHAB-LD.

Em 2006, como resultado da 1ạ Conferência Municipal da Habitação, foi instituída a Política Municipal da Habitação, e constituídos o Conselho Municipal da Habitação e o Fundo Municipal da Habitação. No período de 2008 e 2009 a atuação se deu por meio dos recursos do Fundo Nacional da Habitação de Interesse Social (FNHIS) e de Gestão da Política de desenvolvimento (PGPD), assim como saldos residuais de Programas HBB (SRCPHBB).

A partir do levantamento do PEMAS (HBB-BID), foram identificadas as ocupações irregulares consideradas, com base em critérios minimamente definidos pelo Plano, em

117 O Programa de Arrendamento Residencial (PAR) tem como objetivo a produção de unidades habitacionais que são arrendadas com opção de compra ao final do período do contrato. A gestão do Programa cabe ao Ministério das Cidades e sua operacionalização à Caixa Econômica Federal - CEF. Os recursos para a produção do programa vêm do FAR - Fundo de Arrendamento Residencial.

118 O Programa Habitar Brasil/BID é financiado pelo Banco Interamericano de Desenvolvimento - BID - e tem como foco traçar soluções para áreas em que residem famílias em condições de subnormalidade. "O programa Habitar Brasil (BID) incentiva a geração de renda e o desenvolvimento em assentamentos de risco ou favelas para melhorar as condições habitacionais. São promovidas, por exemplo, as seguintes ações: construção de novas moradias, implantação de infraestrutura urbana e saneamento básico, e recuperadas áreas ambientalmente degradadas. A CAIXA é o agente financeiro, técnico, operacional e responsável pela implementação do programa" (Caixa Econômica Federal, 2019). O programa promoveu a implantação de projetos integrados, que no caso de Londrina contemplaram a remoção de famílias de áreas de fundo de vale, a construção de unidades habitacionais para atender às famílias removidas e a revitalização do Fundo de Vale alvo das remoções. 
situação de risco e, por isso, deveriam ser removidas. Assim, o desfavelamento continuou na pauta por meio de ações de remoções.

O programa foi realizado no Jardim Maracanã na primeira fase, intitulada Projeto UAS do HBB I, e no fundo de vale da microbacia do Córrego Sem Dúvida na segunda fase, o Projeto UAS do HBB II, ambas realizadas pela Cohab-LD. O Projeto UAS do HBB II foi realizado entre 2003 e 2005, e atendeu um total de 122 famílias. Estas famílias foram realocadas no Jardim Primavera II, nas proximidades da área de origem. O projeto também previu a regularização fundiária das unidades. Depois da remoção foram feitas as ações de revitalização do Fundo de Vale ${ }^{119}$. No entanto, em 2014 o Fundo de Vale foi novamente ocupado.

Ainda com o repasse da Caixa Econômica do recurso do Programa Habitar BrasilBID, foi realizado um Plano de ZEIS para Londrina. O Plano foi realizado utilizando como base o levantamento e diagnóstico do PEMAS, ou seja, demarcou as Zonas Especiais de Interesse Social de acordo com as definições de remoção/regularização abordadas no PEMAS, com algumas atualizações e adequações.

No final de 2009 foi entregue o Plano de Zonas Especiais de Interesse Social, que fazia uma caracterização e quantificação do déficit habitacional de Londrina e soluções para aplicação de ZEIS com a delimitação de zonas de regularização fundiária, zonas de remoção de fundo de vale e zonas de vazios urbanos localizadas próximas às zonas de remoção para relocação das famílias removidas, e áreas para reserva de terras para futuros conjuntos habitacionais nas áreas de expansão. Além de cursos promovidos sobre ZEIS e de reuniões com a comunidade, o Plano seguiu as diretrizes do Ministério das Cidades para a aplicação desse instrumento e contemplava também a conciliação com outros instrumentos antiespeculativos previstos na Lei do Plano Diretor. O plano trazia soluções que aparentemente rompiam com o padrão descrito que predominava no município e dava indicativos para uma política habitacional mais ampla, entretanto reproduziu algumas definições estabelecidas no PEMAS.

${ }^{119}$ Cordeiro (2006; 2015); Santos (2010). As ações foram no sentido de retirar lixo e entulhos dos barracos demolidos e implantação de equipamentos de lazer. Portanto, caracterizaram ações de embelezamento do local, sem aprofundamento na recuperação ambiental do córrego. 
Em 2010 o Plano de ZEIS foi encaminhado para a Câmara de Vereadores para votação do Projeto de Lei Específica das Zonas Especiais de Interesse Social, conforme previsto do PDM. Entre idas e vindas e muitas polêmicas, houve um atraso na votação. Nesse período, durante a gestão de Barbosa Neto (2009-2012), a prefeitura de Londrina havia fechado o contrato com o Governo Federal para implantação do Programa MCMV. Em 2011 o Plano de ZEIS foi retirado de pauta e engavetado.

Entre 2008 e 2009 foram realizados dois programas com recursos do Fundo Nacional de Habitação de Interesse Social: FNHIS 2008 e FNHIS 2009, articulados também com obras de urbanização com recursos do PAC - Programa de Aceleração do Crescimento. Seguindo a lógica empreendida pelo PEMAS, estes programas promoveram a remoção de famílias, principalmente de fundos de vale, para empreendimentos e unidades habitacionais construídas em terrenos próximos às áreas de origem das famílias. Também foram realizadas ações de recuperação dos fundos de vale, porém voltadas ao embelezamento. Foram poucas unidades construídas em números absolutos, mas que consideraram a região em que as famílias estavam inseridas (esta era uma diretriz do Ministério das Cidades). Apesar de estar prevista a etapa de documentação das famílias atendidas nestes programas, isto só ocorreu durante o Programa de Regularização Fundiária que será analisado adiante.

Em 2011 foi elaborado o Plano Local de Habitação de Interesse Social utilizando o conteúdo e reforçando os critérios e a lógica do PEMAS e do Plano de ZEIS ${ }^{120}$.

\footnotetext{
${ }^{120}$ No PLHIS foi quantificado o déficit total de Londrina para 2010 em 14.001 domicílios. Em uma revisão dos cálculos do PLHIS de Londrina verifiquei que foram utilizadas fontes de dados de períodos distintos e quantitativos desatualizados, portanto não há precisão nos valores absolutos apresentados no plano.
} 
Tabela 3 - Empreendimentos habitacionais construídos com recursos do FNHIS, PAC, HBB e OGU em Londrina - Década de 2000

\begin{tabular}{|c|c|c|c|c|}
\hline \multicolumn{5}{|c|}{ Programa Urbanização, Regularização e Integração de Assentamento Precários } \\
\hline \multirow[t]{2}{*}{ RECURSO } & \multirow[t]{2}{*}{ OBRA } & \multirow[t]{2}{*}{ LOCALIDADE } & № & ASSINATURA \\
\hline & & & UHs & DO CONTRATO \\
\hline \multirow[t]{6}{*}{ FNHIS 2008} & \multirow{3}{*}{$\begin{array}{l}\text { Execução de unidades } \\
\text { habitacionais }\end{array}$} & CH Jamile Dequech & 10 & \multirow[t]{6}{*}{$21 / 02 / 2011$} \\
\hline & & Jardim Felicidade & 45 & \\
\hline & & Jardim Nova Esperança & 62 & \\
\hline & \multirow[t]{3}{*}{$\begin{array}{l}\text { Recuperação de fundo } \\
\text { de vale }\end{array}$} & $\begin{array}{l}\text { CH Nubar Boghossian, José } \\
\text { Belinati }\end{array}$ & - & \\
\hline & & $\begin{array}{l}\text { Jardim Novo Perobal, } \\
\text { Franciscato e Fazenda Refúgio }\end{array}$ & - & \\
\hline & & Jardim Belle Ville & - & \\
\hline \multirow[t]{4}{*}{$\begin{array}{l}\text { FNHIS } 2009 \\
\text { Etapa } 01\end{array}$} & $\begin{array}{l}\text { Execução de unidades } \\
\text { habitacionais }\end{array}$ & Residencial Horizonte II & 293 & 19/04/2011 \\
\hline & \multirow{3}{*}{$\begin{array}{l}\text { Recuperação de fundo } \\
\text { de vale } \\
\text { (não concluído) }\end{array}$} & $\begin{array}{l}\text { Residencial do Café, Palmas, } \\
\text { Paracatu e Ilha do Mel }\end{array}$ & - & \\
\hline & & CH Hilda Mandarino & - & \\
\hline & & Residencial Horizonte II & - & \\
\hline $\begin{array}{l}\text { FNHIS } 2009 \\
\text { Etapa } 02\end{array}$ & $\begin{array}{l}\text { Equipamentos } \\
\text { comunitários }\end{array}$ & $\begin{array}{l}\text { Barracão de reciclagem } \\
\text { (Residencial Horizonte) }\end{array}$ & - & 05/07/2011 \\
\hline \multirow[t]{3}{*}{$\begin{array}{l}\text { FNHIS } 2009 \\
\text { Etapa } 03\end{array}$} & \multirow[t]{3}{*}{$\begin{array}{l}\text { Equipamentos } \\
\text { comunitários }\end{array}$} & $\begin{array}{l}\text { Centro Comunitário } \\
\text { (Residencial Horizonte) }\end{array}$ & - & \multirow[t]{2}{*}{$01 / 12 / 2011$} \\
\hline & & $\begin{array}{l}\text { Centro Comunitário } \\
\text { (Residencial Vista Bela) }\end{array}$ & - & \\
\hline & & TOTAL & 410 & \\
\hline \multicolumn{5}{|c|}{ Programa de Urbanização de Assentamento subnormal - UAS } \\
\hline \multirow[t]{2}{*}{ RECURSO } & \multirow[t]{2}{*}{ OBRA } & \multirow[t]{2}{*}{ LOCALIDADE } & № & ANO DE \\
\hline & & & UHs & ENTREGA \\
\hline PAC & Execução de unidades & Jardim Primavera & 257 & 2010 \\
\hline \multirow[t]{2}{*}{ HBB } & \multicolumn{3}{|l|}{ habitacionais } & \\
\hline & $\begin{array}{l}\text { Recuperação de fundo de } \\
\text { vale }\end{array}$ & Rua Ana Caputo Piacentini & - & \\
\hline \multirow[t]{5}{*}{ OGU } & \multirow{3}{*}{$\begin{array}{l}\text { Execução de unidades } \\
\text { habitacionais }\end{array}$} & Jardim Vila Romana & 18 & 2012 \\
\hline & & Jardim Primavera & 15 & \\
\hline & & Jardim Santa Joana & 2 & \\
\hline & \multirow[t]{2}{*}{$\begin{array}{l}\text { Recuperação de fundo de } \\
\text { vale }\end{array}$} & Jardim Rosa Branca & - & \\
\hline & & TOTAL & 292 & \\
\hline
\end{tabular}

Fonte: Cohab-LD (2018).

Neste breve panorama da habitação social em Londrina, procurei destacar como a informalidade foi tratada pelo poder público municipal. Apesar de diferenciar dois períodos - até 2000 e após 2000 -, ficou evidente que o discurso e a prática do 
desfavelamento permearam todas essas décadas, independente do perfil da gestão municipal e o perfil e o foco da gestão da Cohab-LD. O discurso e a prática do desfavelamento, em um descompasso resultante da impossibilidade real de promovêlo, também estão presentes no conteúdo dos dois programas que aprofundo na sequência deste trabalho. Deste modo, no próximo tópico, recuperando os documentos oficiais, entrevistas, leis, entre outros, busco compreender como o discurso do desfavelamento combinado a outros discursos e abordagens próprios do planejamento higienista e ideológico, construíram as verdades que levaram ao consenso em torno do modo de atuação da Cohab-LD frente ao crescimento da informalidade. 


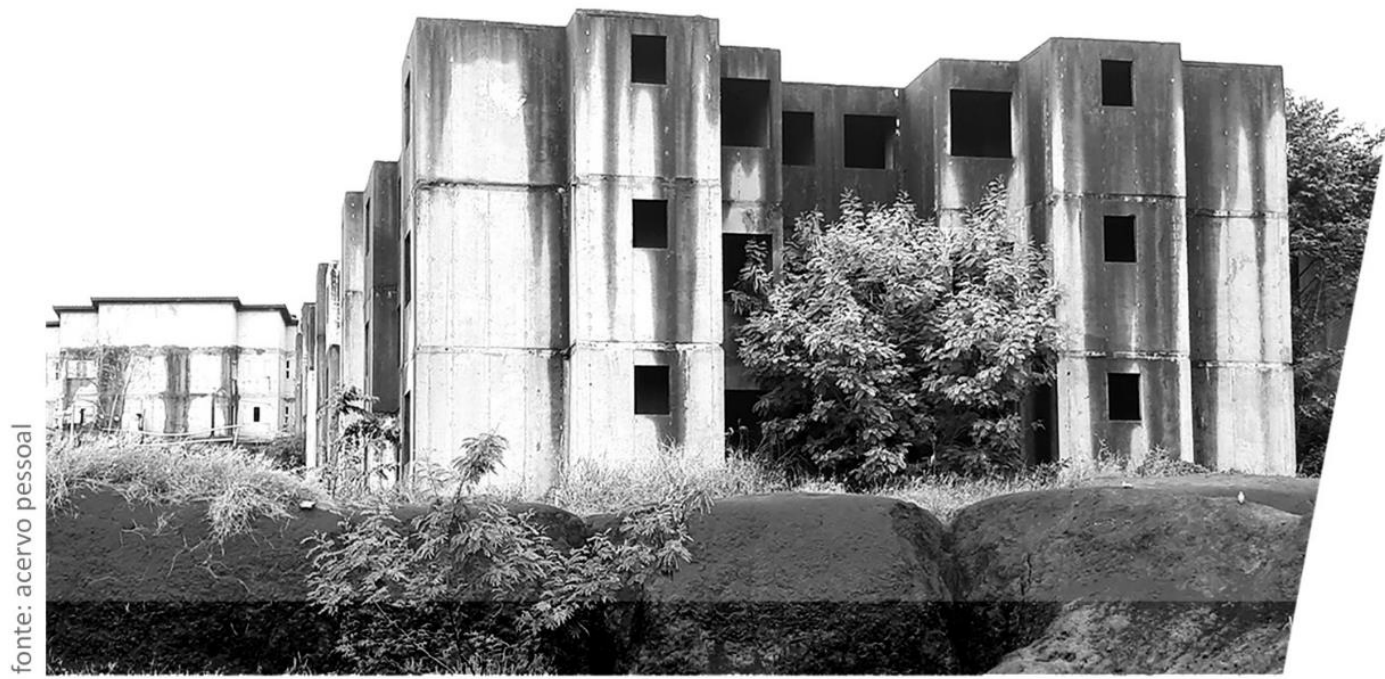




\title{
Rompendo a dicotomia formal/informal
}

\section{A informalidade como um modo de urbanização}

\begin{abstract}
É isso o que está aqui sendo visado ao se chamar a atenção para o que acontece nas dobras do legal-ilegal. Não se trata de tomar essa binaridade como chave explicativa, mas de prospectar seus efeitos, o modo como os jogos de poder se configuram nesses espaços, a distribuição diferenciada dos controles e, em torno deles, os agenciamentos práticos que se curvam ou que escapam aos dispositivos de poder implicados nessas categorias e codificações. ${ }^{121}$
\end{abstract}

A abordagem sobre a informalidade urbana foi tratada, historicamente, a partir da oposição entre o formal e o informal, o legal e o ilegal ${ }^{122}$. No entanto esta dicotomia como chave explicativa não só criou um "campo cego"123 para os estudos sobre a cidade como também serviu de base para programas e políticas que tiveram resultados questionáveis, muitos deles, por exemplo, relacionados aos programas de intervenção e remoção de favelas.

Sem desconsiderar o viés político e a importância que algumas dessas abordagens tiveram ao evocar a diferenciação entre a "cidade legal" e a "cidade real", em muitos casos e ao alcance do senso comum, a diferenciação foi apropriada para invisibilizar e criminalizar a pobreza, e a informalidade foi incorporada em discursos oficiais como sinônimo de algo que está errado e deve ser combatido ${ }^{124}$. A redução,

\footnotetext{
121 Telles e Hirata (2010, p. 41).

122 Segundo Rosa (2008).

123 Lefebvre (2002).

124 Rosa (2008, p.38) diferencia internamente essas abordagens e constrói um quadro do enfoque da dualidade formal/informal, legal/ilegal nos debates sobre a cidade. A autora mostra como a dualidade foi incorporada no discurso tanto para dar visibilidade aos processos e efeitos da segregação urbana no contexto do Movimento pela Reforma Urbana (balizados pelo conceito de Direito à Cidade) e associada à "criminalização e marginalização generalizada" e ao combate à "desordem". Nestes casos "reapropriada pela mídia, pelo discurso competente de políticos e profissionais, por organizações não-governamentais, por agências multilaterais e de financiamento internacional." Além de evidenciar o que chama de "deslocamento de sentidos" nas abordagens sobre a informalidade, Rosa (2008, p.35) levanta questionamentos pertinentes a respeito da teoria e prática sobre a pobreza e a vida na favela quando pautadas pela dicotomização: "não deixaria escapar as relações extremamente dinâmicas e móveis que caracterizam na prática tais fronteiras, (...) recaindo, muitas vezes, em interpretações - e intervenções homogeneizantes sobre as favelas e periferias".
} 
homogeneização e o caráter pejorativo também estão associados à negação e desconhecimento dos meandros da pobreza urbana, justificando e legitimando o discurso da erradicação.

Entretanto, a legislação é responsável por definir esse limiar imaginário, enquadrando na normalidade aquilo que convém em um determinado momento. À medida que os interesses e as relações de poder se deslocam, a legislação é acionada para legitimar as mudanças ${ }^{125}$. Por isso, a legislação não pode ser considerada nesta discussão apenas da perspectiva das "ideias fora do lugar" ${ }^{126}$, mas também deve ser considerada como um dispositivo em disputa nas relações de poder que incidem sobre a produção do espaço urbano.

Tendo em vista que o positivismo jurídico em voga "reduz o legítimo ao legal"127, o que está em jogo é a capacidade de conferir legitimidade a relações, práticas e discursos. Para compreender a disputa, o questionamento de Fernandes $(2001$, p.22) é pertinente: "quem participa da elaboração das leis? Quem tem o poder decisório?". Ainda que, no Brasil, a aplicação da lei seja claramente seletiva.

Partindo, portanto, da premissa de que são fluidas as fronteiras entre o informal e o formal é que sigo para a reflexão acerca do planejamento urbano como processo que tem reconhecido como legítima apenas a cidade produzida e gerida pelo mercado formal. Considerando essa fluidez, torna-se possível compreender o discurso da flexibilização em alta atualmente para evocar a supressão da lei em diferentes ocasiões com a finalidade de beneficiar os interesses dos investidores nas obras de urbanização,

\footnotetext{
${ }^{125}$ Aqui me referencio em Telles e Hirata (2010) sobre a noção Foucaultiana de "gestão diferencial dos ilegalismos". Nessa noção, as leis têm efeitos de poder e "operam não para coibir ou suprimir os ilegalismos, mas para diferenciá-los internamente, 'riscar os limites de tolerância, dar terrenos para alguns, fazer pressão sobre outros, excluir uma parte, tornar útil outras, tirar proveito daqueles'" (Foucault, 2006, p.227, Apud Telles e Hirata, p.41). Sobre isso, um marco que foi determinante no contexto brasileiro corresponde à Lei de Terras - Lei Imperial no 601 de 1850 - que, como mostra Rolnik (1997), foi criada para a sustentação do poder após a abolição da escravidão e a incorporação do trabalho livre no Brasil.

${ }^{126}$ Esta expressão originalmente cunhada por Schwarz (1992) é utilizada por Maricato (2000) para explicar em parte as razões das discrepâncias entre a cidade idealizada nos planos e nas leis e aquela que se efetiva na urbanização brasileira. As referências pautadas em experiências internacionais e a desconsideração quanto aos conflitos e particularidades da realidade brasileira teriam levado à constituição de normativas inalcançáveis e descompassadas em relação às dinâmicas da produção das cidades.

${ }^{127}$ Fernandes (2001, p.22).
} 
produzindo a "cidade de exceção"128. E, assim, vão sendo redefinidos os critérios das formas toleradas de informalidade.

Considerando que a produção e reprodução de capital se desenvolvem em um campo de possibilidades, a flexibilidade se torna fator fundamental para ampliá-lo ${ }^{129}$. O Estado, responsável pela aplicação da lei, tendo em vista a racionalidade que emerge, deve permitir que as normas de autorregulação ocupem o lugar da lei ${ }^{130}$.

A adoção de um "estado de exceção", nesse sentido, passa a ser compreendida também como uma epistemologia do próprio planejamento urbano ${ }^{131}$, já que por meio deste é que o Estado vai determinar o que e, em que momento, pode ser reconhecido como legítimo, tolerado e, ainda, incorporado à legalidade. Não podemos deixar de lembrar ainda que nem tudo que se encontra em situação de ilegalidade na cidade é combatido.

As obras de urbanização em desconformidade com a lei, mesmo que de certa forma "autorizadas" pelo poder público sob a lógica da flexibilização, caracterizam um tipo de informalidade urbana, e é por isso que a informalidade segue sendo um temachave da pesquisa contemporânea sobre os países em desenvolvimento ${ }^{132}$.

Por isso é necessário enxergar a informalidade como um modo de urbanização ${ }^{133}$, uma organização lógica que norteia o processo da transformação

${ }^{128}$ A "cidade de exceção" é a expressão cunhada por Vainer (2011) para caracterizar a postura do poder público perante as obras de urbanização para os mega-eventos no Rio de Janeiro. Para criar esse conceito, o autor se referencia em Agambem (2004) e Poulantzas (1986) articulando as ideias de "estado de exceção" e, como uma característica dele, a "autonomia relativa do estado". Nesse sentido, o autor defende a ideia de que "o estado de exceção redefine as formas através das quais os interesses dominantes se fazem presentes no estado" (Vainer, 2011, p. 9). Complementa dizendo que "a cidade de exceção se afirma, pois, como uma nova forma de regime urbano. (...) A lei torna-se passível de desrespeito legal e parcelas crescentes de funções públicas do estado são transferidas a agências "livres de burocracia e controle político" (Vainer, 2011, p. 10).

${ }^{129}$ Vainer (2000).

${ }^{130}$ Laval e Dardot (2013).

131 Também referenciada em Agambem (1998), Roy (2007) aborda a estratégia do "estado de exceção" como uma epistemologia do planejamento urbano. Para a autora, "o planejamento e o aparato legal do estado tem o poder de determinar quando decretar sua suspensão, para determinar o que é informal e o que não é, e determinar quais as formas de informalidade que irão prosperar e quais irão desaparecer" (Roy, 2007, p. 149).

132 Roy (2007).

${ }^{133}$ Roy (2007). A autora se propõe a discutir como as diferentes modalidades de planejamento são responsáveis por produzir aquilo que não é "planejável". Constata-se a coerência da teoria de Roy, se se 
urbana. Importante destacar que a informalidade nos processos de urbanização de que se trata não se restringe à população de baixa renda. São também importantes estratégias para a classe média e até para a elite dos países periféricos ${ }^{134}$.

Neste contexto, dois tipos de assentamentos informais se destacam: um, caracterizado pela ocupação de terra e autoconstrução, e, outro, loteamento de luxo em desacordo com a legislação de parcelamento ou uso e ocupação do solo, podem coexistir mostrando que não se trata apenas da polaridade entre formal e informal, mas que são diferentes situações dentro das formas de informalidade ${ }^{135}$. A grande diferença entre as duas está na "autonomia relativa do estado"136 para decidir qual delas permanecerá na informalidade e para qual se aplicará o "estado de exceção". Como dito anteriormente, a indistinção entre poder público e setor privado sugere como tem sido tomada essa decisão.

Sendo assim, o Estado em sua multiplicidade de atores tem o poder de decidir qual o tipo de solução que predomina em cada momento, claramente em consonância com a proposta desenvolvimentista de impulsão da economia via produção imobiliária.

Apesar do alerta de Francisco de Oliveira ${ }^{137}$ para os riscos das abordagens dualistas para a construção da teoria e das práticas, a oposição formal/informal foi base teórica que embasou discursos e soluções em diferentes momentos da história para diferentes políticas públicas. Entre elas, destaco o desfavelamento.

\footnotetext{
entende que a legislação define critérios para deliberar o que é formal e, como consequência, o que não se encaixa nos parâmetros é automaticamente entendido como informal. O planejamento não considera cidade a produção informal. Porém, ela existe e representa uma grande parte das cidades brasileiras.

${ }^{134}$ Roy e AlSayyad (2004).

135 Roy (2007)

${ }^{136}$ Sobre a relativa autonomia do Estado, Lefebvre afirma “(...) que a burguesia, classe dominante, dispõe de um duplo poder sobre o espaço; primeiro, pela propriedade privada do solo que se generaliza por todo o espaço, com exceção dos direitos das coletividades e do Estado; segundo pela globalidade, a saber, o conhecimento, a estratégia, a ação do próprio Estado" (Lefebvre, 2008, p.57).

137 Oliveira (2007).
} 


\section{Desfavelamento como resposta à dicotomia}

Segundo Santos (1988, p.18), é possível diferenciar dois momentos diferentes quanto à postura do Estado diante das favelas das grandes cidades. Um primeiro momento, que ele recorta entre 1930 e 1950, é marcado pela "permissividade" e tolerância, resultando em um alastramento das favelas. Como essa solução precária de moradia exerceu um papel favorável ao mercado, não houve pressão para que outro tipo de postura fosse adotado.

Já na década de 1960, começa um “ataque em massa às favelas, pretendendo erradica-las todas"138. Segundo o autor, esse combate às favelas tem início com ações municipais, mas avança como política centralizada no Governo Federal pelos programas criados no âmbito no Banco Nacional da Habitação.

Na mesma linha, Valladares (1978) analisa o caso das remoções de favelas no Rio de Janeiro da década de 1960, diferenciando-as das soluções adotadas antes dessa década, relacionadas à urbanização dos assentamentos precários. A autora mostra que propostas de eliminação das favelas eram constantemente elaboradas e praticadas simultaneamente às propostas de recuperação e serviços assistenciais, visando melhorias na qualidade de vida dos moradores de outras favelas. O resgate do trabalho de Valladares tem o objetivo de mostrar como o conceito de regularização simbolizava uma oposição à prática da remoção.

Inicialmente, as primeiras propostas visavam eliminar as favelas e coibir a construção de novas favelas. Depois, passaram à proposta de higienizar as favelas construindo residências de alvenaria no próprio terreno da favela enquanto as pessoas ficavam provisoriamente em Parques Proletários construídos para esse fim. No entanto, a volta das famílias não se concretizou e os parques proletários se tornaram novas favelas produzidas pela própria prefeitura. Outras ações de urbanização e assistência foram realizadas em parceria com entidades religiosas. Depois, surgiu novamente a intenção de exterminar as favelas, mas nenhuma ação se concretizou. Novas ações de

\footnotetext{
${ }^{138}$ Santos (1988, p.18).
} 
urbanização foram empreendidas e coordenadas pela Arquidiocese do Rio de Janeiro, agora com mais expressividade ${ }^{139}$.

Segundo Valladares a origem dessas soluções - os parques proletários - tinham o objetivo, em primeiro lugar, de controlar milhares de pessoas, principalmente considerando o potencial de revolta das grandes aglomerações de pessoas ${ }^{140}$.

Em 1956 foi criado no Rio de Janeiro o SERFHA - Serviço Especial de Recuperação de Favelas e Habitações Anti-Higiênicas -, primeiro órgão oficial destinado à urbanização de favelas. Valladares chama a atenção para o fato de que todas as ações visavam a extinção ou a realização de melhorias nas favelas, mas nenhuma delas conseguiu concluir seus objetivos.

Na década de 1960 a perspectiva mudou e foi criado o programa de remoção que visava a transferência das famílias residentes nas favelas para vilas e conjuntos habitacionais produzidos pela Cohab-GB. Com base nas polêmicas geradas pelas remoções, a urbanização veio como uma alternativa oposta. Ao mesmo tempo que a Cohab-GB promovia a remoção das favelas, a Companhia de Desenvolvimento de Comunidade - CODESCO - promovia as obras de urbanização em outras favelas. A solução pela via da urbanização estava pautada justamente nas polêmicas em torno das remoções, e teve maior aceitação principalmente por "responder às aspirações dos moradores locais" ${ }^{141}$, de onde veio o slogan usado naquele período pela FAFEG Federação das Associações de Favela do Estado da Guanabara: "Urbanização Sim, Remoção Nunca".

O fato de os dois organismos funcionarem em paralelo com ações que representam objetivos opostos, demonstram que não há um consenso em relação às soluções. A ausência de consenso também se deu no campo intelectual, que desenvolveu teorias buscando compreender e solucionar o problema das áreas precárias. Para Santos (1998), a causa está relacionada à articulação fundamental entre

\footnotetext{
${ }^{139}$ Valladares (1978).

${ }^{140}$ Santos (1988). Sobre isso, Valladares (1978 p.26) cita artigo da SAGMACS sobre as intervenções nas favelas “(...) é preciso subir o morro antes que dele desçam os comunistas."

${ }^{141}$ Valladares (1978, p.25).
} 
o núcleo e a periferia. Para ele, o núcleo privilegiado só atinge o desenvolvimento apoiado no desenvolvimento da periferia. Sendo assim, a ideia de "extermínio" é ilusória.

A busca por legitimidade para a práticas fez com que o Estado buscasse nessas teorias a justificativa para as ações que interessavam em cada local e em cada momento.

No Brasil houve bastante polêmica entre as duas correntes, em particular quando, a partir dos anos 1960, o Governo foi buscar em uma delas os argumentos ideológicos justificativos de seus planos e programas. É, de fato, a teoria da marginalidade urbana, ou suas versões mais ou menos mascaradas, que vão estar por trás das primeiras grandes remoções de favelas dos Núcleos para conjuntos habitacionais nas Periferias ${ }^{142}$.

O que está em xeque na análise da execução de instrumentos da política habitacional são as respostas oferecidas pelo Estado para o "problema da informalidade urbana". Ou, nos termos de Roy, quais as formas de informalidade que serão toleradas em um determinado momento e em um determinado lugar, e quais não serão. Enquanto a ocupação informal de um determinado espaço supre precariamente a demanda por moradia isentando mercado e Estado da responsabilidade de arcar com essa deficiência, ela é tolerada. Quando ela se torna incômoda, passa a ser objeto da política habitacional. Nesse sentido, interessa compreender como são estabelecidos os critérios que enquadram determinadas ocupações irregulares nos parâmetros para o desfavelamento e para a regularização fundiária.

142 Santos (1988, p.33). 


\section{O desfavelamento como verdade instituída}

(...) tal discurso pode aparecer como (...) elemento que permite justificar e mascarar uma prática que permanece muda; pode ainda funcionar como reinterpretação desta prática, dando-lhe acesso a um novo campo de racionalidade. ${ }^{143}$

Em diferentes momentos da pesquisa, entre entrevistas, relatos e documentos, observa-se um tipo de consenso em torno das remoções. A principal justificativa, que também se repete em diferentes fontes e momentos, é a questão da preservação e recuperação ambiental. Como grande parte das ocupações se dá em fundos de vale, o que se observa é que foi construído um único argumento possível: a remoção das famílias do local.

Buscando compreender a construção desse discurso que justifica e legitima as práticas, resgatei leis, documentos e referências que historicamente fizeram parte da abordagem sobre esse tema. Neste resgate, esta prática é colocada nos termos do "desfavelamento".

No começo, o discurso era de combater o surgimento e crescimento das primeiras favelas, mas já se observa que o "desfavelamento" era aplicado de forma seletiva, e os critérios desta seleção não são sempre explícitos. A justificativa para as remoções também foi pautada pelos preços dos terrenos ocupados, porém este argumento é pontual e não fica explícito nos documentos mais recentes.

O que procuro discutir neste tópico, portanto, é como o discurso do "desfavelamento" tem sido construído ao longo do tempo pautado principalmente no discurso da proteção ambiental, do sanitarismo ${ }^{144}$ e do embelezamento.

O modelo de ocupação proposto pela CTNP fez com que, na medida em que a cidade avançou e as glebas rurais foram sendo incorporadas e parceladas para fins urbanos, a cidade ficou "cortada" por fundos de vale em quase toda sua extensão. Nas

\footnotetext{
${ }^{143}$ Foucault (1998, p. 174)

${ }^{144}$ Sobre os sanitaristas ver Tochetto e Ferraz (2015).
} 
regiões leste, oeste e norte, onde os investimentos públicos são mais precários (comparados com a zona sul, por exemplo), os fundos de vale ficaram com marcas do abandono (pelo poder público e pela população) e, muitos deles, passam a ser destino de lixo, resíduos de construção, e outros são ocupados por famílias de baixa renda formando favelas.

Tendo em vista que o conflito é iminente nos casos de ocupações em áreas particulares, que as famílias que passam pela reintegração de posse não têm garantias no atendimento, e que as remoções de famílias de fundos de vale aconteceram, como visto, para terrenos da Cohab-LD são, assim, percebidas como garantia de relocação: o dispositivo criou um sujeito.

Os discursos do embelezamento e do higienismo/sanitarismo começaram a aparecer nos primeiros documentos da Cia de Terras e na legislação desde a formação de Londrina. Esse discurso foi incorporado na legislação urbanística e, na década de 70, quando o poder público começou a perder o controle dos parcelamentos do solo e que houve um crescimento significativo nas áreas de moradia precária, também foi contratado o Plano Diretor de Desenvolvimento Urbano elaborado pela $\operatorname{ASPLAN}^{145}$ que deu ênfase e critérios para a conservação das áreas de fundos de vale e a criação da faixa sanitária ${ }^{146}$.

O pensamento higienista que influencia a consolidação da legislação urbanística de São Paulo - e depois reverbera para a concepção e consolidação da legislação em Londrina, com a vinda de Prestes Maia - visa "desadensar e eliminar o alojamento dos pobres, para livrá-los da ameaça da moral e da morte"147. Prestes Maia foi contratado

\footnotetext{
${ }^{145}$ A ASPLAN - Assessoria de Planejamento possuía sua sede na cidade de São Paulo.

${ }^{146}$ A faixa sanitária adotada em Londrina, com base no Plano Diretor de 1968, corresponde a uma faixa de $30 \mathrm{~m}$, além dos $30 \mathrm{~m}$ correspondentes à área de preservação permanente (APP) nas margens dos córregos. A primeira vez que se fala em preservar uma faixa verde além da linha de enchente máxima do rio para arborização, ajardinamento e serviços foi no Art. 23 da Lei Municipal no 133/51, que teve Prestes Maia como consultor. A determinação para preservação da faixa sanitária foi prevista efetivamente pela primeira vez no Cap II, Art. 40, item d do inciso V do Plano Diretor Municipal de 1968. No Art. 25 desta lei são definidas as dimensões das faixas de preservação de acordo com o tamanho da Bacia Hidrográfica do córrego correspondente. A faixa de $30 \mathrm{~m}$, que foi padronizada na área urbana, correspondia às bacias com área total entre 2.000 a 5.000 ha.

${ }^{147}$ Rolnik (1997, p.40)
} 
para a elaboração da Lei Municipal no 133/1951, considerada o primeiro Plano Diretor de Londrina.

Algumas peculiaridades do projeto da Cia de Terras para a implantação do município de Londrina levaram a essa configuração morfológica da área urbana. Inicialmente, a área urbana era cercada por lotes rurais de pequenas ${ }^{148}$ dimensões, com suas frentes e fundos sempre voltados para uma via de circulação e para um córrego, respectivamente $^{149}$. Esta morfologia permanece quando as glebas rurais são incorporadas ao espaço urbano no processo de expansão da malha urbana, fazendo com que esta seja cortada por córregos, principalmente na direção leste-oeste, o que tornou o sítio físico da cidade acidentado na direção norte-sul (mapa).

Essas áreas de preservação permanente inseridas na área urbana são doadas ao município no momento da aprovação dos loteamentos tornando-se áreas públicas sem possibilidade de comercialização. Ainda, a legislação municipal exige a abertura de uma via marginal de fundo de vale, o que garante acesso às áreas verdes. Essas duas características acabam facilitando as ocupações irregulares nessas áreas.

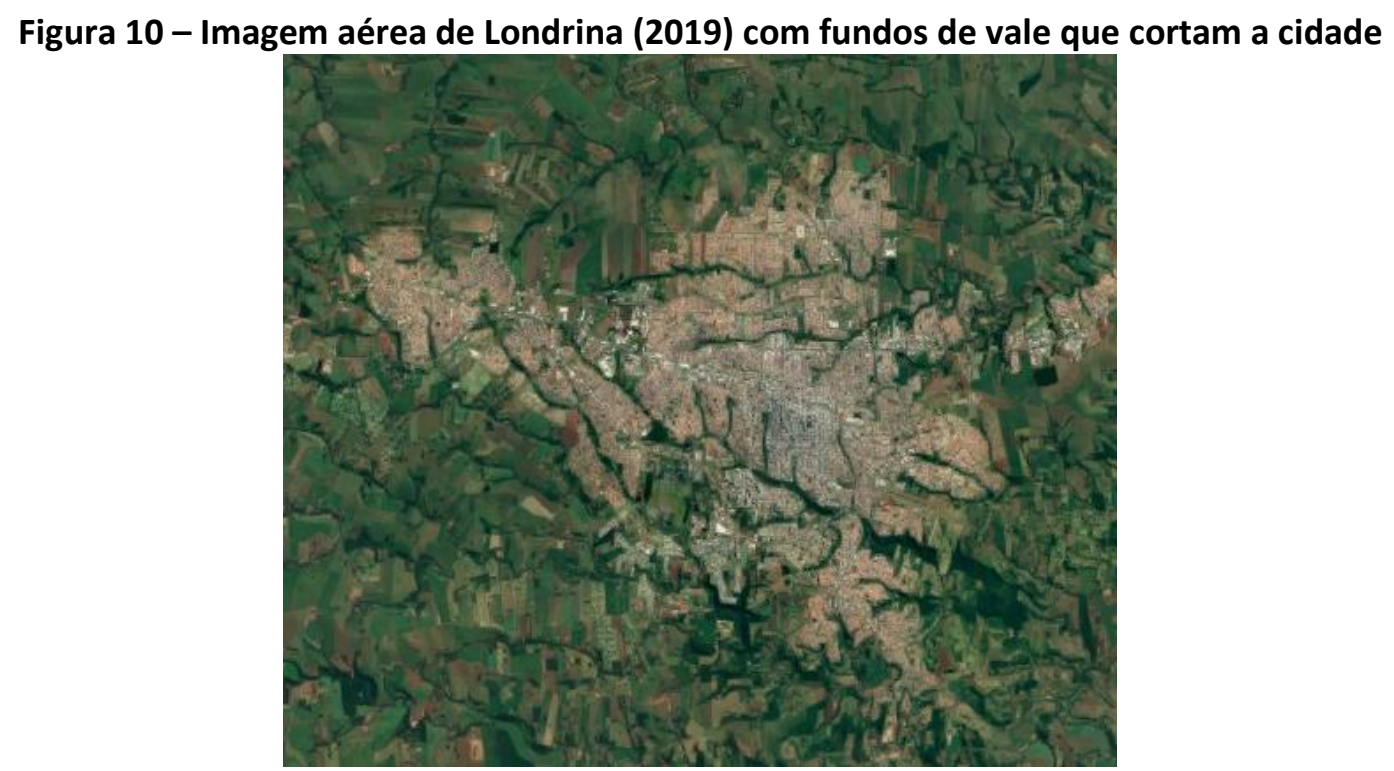

Fonte: Google Earth (2019)

\footnotetext{
148 Pequenas dimensões se comparadas aos latifúndios de produção agrícola existentes pelos país. 149 Yamaki (2003).
} 


\section{Embelezamento e higienismo-sanitarismo}

Segundo Yamaki (2006, p.12), "Ordenar, embelezar e cuidar da higiene eram alguns dos princípios de construção de cidades adotados pela CTNP". Com o objetivo de construir a "imagem de uma urbes moderna." ${ }^{150}$, por meio de decretos entre as décadas de 1930 e 1940, a Companhia de Terras regulou a construção de muros, implantação de jardins, a proibição de construções em madeira, dentre outras coisas, visando a disseminação dos princípios do embelezamento e do higienismo.

Uma das evidências da influência do pensamento higienista nas ações na CTNP151 foi a criação de uma avenida larga dotada de jardins que contrastava com as avenidas estreitas no traçado inicial. A abertura da Avenida Higienópolis concebida por Arthur Thomas próxima às áreas mais nobres do plano, ainda que não estivesse prevista no plano inicial da CTNP, buscava a referência do estilo de vida paulistano para esta cidade que estava começando. Com a consolidação da ocupação no centro da cidade e no entorno da Avenida, ela passou a representar uma espécie de "aburguesamento" da sociedade londrinense com exclusividade imposta pela construção dos "palacetes" dos Barões do Café e dos principais empresários da cidade ${ }^{152}$.

Outras medidas com esse mesmo sentido são descritas por Yamaki (2006, p.14) sobre a tentativa de controlar o crescimento do empreendimento. "(...) editais, decretos e leis procuravam definir, logo nos primeiros anos, algumas estratégias para o controle possível da higiene, do bem-estar dos moradores e da paisagem." Dentre essas medidas, estavam a limpeza da rua de obrigação dos residentes (Edital, 5 nov. 1936); a limpeza

\footnotetext{
${ }^{150}$ Yamaki (2006, p.12).

151 Sobre o pensamento higienista, Cordovil (2013) mostra a relação entre Lord Lovat, o engenheiro Mesquita Filho e o engenheiro Jorge de Macedo Vieira, que projetou Maringá a serviço da CTNP. Os engenheiros tinham a mesma formação de Prestes Maia além de alguma proximidade. Por meio deste estudo é possível concluir que a formação dos engenheiros na Politécnica e a relação - estreita - com a Companhia de Terras trouxeram a influência dos sanitaristas para o projeto e as normas estabelecidas pela CTNP em Londrina.

152 Silva e Boni (2009, p. 2). Benatti (1996, p. 22) também relaciona o plano inicial e os preceitos da Cia de Terras aos pressupostos higienistas, ainda que constate que a Companhia perdeu o controle em seguida: "Sonho de investidores e geómetras, fruto de uma racionalidade técnica instrumentalizada pelo capital, a cidade de Londrina nasceu com a perspectiva de um espaço urbano ordenado, estratificado, hierarquizado e higienizado".
} 
de datas e fossas de água servida e destruição de bananeiras para conter focos de mosquitos (Editais 27 out. 38, 17 fev. 39, edital 6 e 7 fev. 41); a instalação de postos de profilaxia antivenérea (Lei no 37, 3 nov. 1937); entre outros.

Durante as décadas de 1930 e 1940, ainda sem infraestrutura e com uma aglomeração crescente, começam os sinais das endemias e da falta de ordenamento. Por isso, neste período, as normas para controle do crescimento dentro dos moldes da “cidade idealizada"153 se intensificam. E esse controle surtiu efeito. Na década de 50 o fortalecimento dessa imagem de cidade colheu resultados, como relata Benatti (1996, p. 31):

A fisionomia da cidade estava mesmo mudada. Em menos de duas décadas, de povoado improvisado e 'caldeirão de malária', a cidade passava a ser celebrada como nova 'capital mundial do café'. O progresso econômico imprimia ao corpo da cidade novos traços e características, remodelando-a totalmente.

As medidas de controle associadas aos intensos investimentos na urbanização, construção dos edifícios institucionais por arquitetos famosos ${ }^{154}$, o início da verticalização, passaram a contrastar com as ruas de terra e as casas de madeira que foram, aos poucos, sumindo da paisagem da nova urbes, que foi se esquecendo dessa época do desbravamento e da sobrevivência.

As mudanças bruscas provocadas pela modernização da cidade decorreram dos altos preços do café no mercado internacional. Em aproximadamente cinco anos durante a década de 50, neste período vigoroso da produção cafeeira, a área urbana de Londrina se transformou (e se modernizou) completamente. A expansão da cidade nesse período (e que se repete ao longo da história da cidade) é tanto em direção às chácaras rurais que se tornam área de expansão da cidade como também verticalmente, adensando o centro da cidade ${ }^{155}$.

\footnotetext{
153 Yamaki (2002).

${ }^{154}$ Arquitetos modernos projetaram edifícios institucionais da cidade como Vilanova Artigas, Carlos Cascaldi e Oscar Niemeyer.

155 Benatti (1996).
} 
A preocupação com o ordenamento cresce também na mesma medida em que os loteamentos se expandem na direção da área rural. Os primeiros sinais da falta de controle na expansão dos loteamentos são contidos com a aprovação do primeiro plano em 1951, quando a influência do traçado orgânico das áreas residenciais e a abertura de avenidas quebram a monotonia do traçado original da CTNP.

As medidas de embelezamento e higiene são exigidas pela legislação desde os editais mostrados por Yamaki, mas também podem ser vistas principalmente nas Leis aprovadas na década de 50, em especial a Lei Municipal no 133/51 que contou com a consultoria de Prestes Maia, reconhecido pelo planejamento urbano regido por princípios higienistas. Neste primeiro momento, os fundos de vale são apenas mencionados como áreas de preservação, mas ainda não adquiriram a importância que será dada no Plano Municipal do final da década de 60.

A primeira menção à preservação de "faixa verde" marginal ao córrego apareceu no artigo 23으 parágrafo 1으 e 2ㅇda Lei Municipal no 133/51 156 .

Nesta mesma Lei, no artigo no $84^{157}$, são definidas zonas residenciais, que são divididas por padrão de renda como, por exemplo, estão descritas nas RI-A, RI-C e RI. PpG, indicando e de certa forma fortalecendo a segregação habitacional.

No Art. 96, "casas econômicas" são definidas como aquelas que têm a finalidade de "facilitar o problema da habitação barata" e que, por isso, a Lei admite que algumas exigências sejam reduzidas como "pé direito, espessura das paredes, áreas de cômodos, revestimentos, etc". A distinção entre casas populares e econômicas é unicamente definida pelo tamanho de lotes, que no caso das casas populares podem ser inferiores aos das casas econômicas (Art. 97).

\footnotetext{
${ }^{156} \S 1$ ㅇ Sempre que possível, será acrescentada, acima da linha das enchentes máximas, uma faixa verde, destinada a ajardinamento, arborização ou serviço.

§ 2ㅇ A Prefeitura fixará a largura mínima livre, a deixar o rio, para garantia da sua vazão e regime, e para obras de regularização acaso cabíveis.

${ }^{157}$ RI-A - Sub-zona de residências individuais, secção de prédios isolados de classe superior; RI-C - Subzona de residências individuais, secção de prédios isolados de classe considerada média; RI.PpG - Subzona de residências individuais "populares", admitidas em renques.
} 
No mesmo Art. 97, também é concedida autorização para diminuição do tamanho dos arruamentos ( $(1 \mathfrak{1})$, e garante a proteção dos empreendimentos populares da "compra em negócio especulativo" ( $6^{\circ}$ ), e ainda fala em "zoneamento popular" no $\S 70$, o que se aproxima de algumas das funções das ZEIS.

É na Lei Municipal no 219/1953 - Código Municipal de Londrina - que a preocupação com a estética das edificações é explicitada, e que a intenção de "extinguir" as moradias insalubres é colocada pela primeira vez. Nessa Lei vários artigos regulam aspectos do embelezamento e do higienismo preconizados para a cidade, como o artigo 35 que exige que as residências da zona urbana sejam revestidas e pintadas. 0 artigo 39 exige a implantação de instalações sanitárias nas edificações situadas em vias dotadas de redes de água e esgoto. Já o artigo 44, devido à proliferação de favelas na cidade, prevê a extinção gradativa das residências insalubres pela Prefeitura Municipal. Considera residências insalubres aquelas que estiverem "edificadas sôbre terreno úmido ou alagadiço; com cômodos insuficientemente arejados ou iluminados; com superlotação de moradores; com porões servindo simultâneamente de habitação para pessôas e depósitos de materiais de fácil decomposição ou de habitação para pessôas e animais em promiscuidade; em que houver falta de assêio geral no seu interior e dependências; que não dispuserem de abastecimento d'água suficiente e as indispensáveis instalações sanitárias."

Ainda, a Lei Municipal no 281 de $1955^{158}$, o Código de Obras Municipal, proíbe a construção de casas de madeira nas proximidades do centro principal (Av. Paraná) e das

\footnotetext{
158 Art. 116 "Não são permitidas edificações de madeira nos lotes situados na área contida pela linha perimetral que parte do cruzamento dos eixos da Av. Paraná com Rua Brasil, prossegue pelo eixo desta última até a faixa da Rede Viação Paraná Sta. Catarina; prossegue pelo eixo da Rua Rio Grande do Sul até o cruzamento com o eixo da Rua Rio Grande do Norte; deste ponto, pelo eixo da Rua Rio Grande do Norte até a faixa da R.V.P.S.C. continuando pelo eixo da Rua Mossoró até o cruzamento com o eixo da Rua Quintino Bocaiuva; deste ponto, pelo eixo da Rua Quintino Bocaiuva até o seu cruzamento com o eixo da Rua Belo Horizonte e pelo eixo desta até o cruzamento com o eixo da Rua Espírito Santo; prossegue pelo eixo da Rua Espírito santo até o cruzamento com o eixo da Rua Brasil deste ponto, pelo eixo da Rua Brasil até o ponto inicial".

$\S 1$ o Para efeito do presente artigo consideram-se, como integrantes da área descrita todos os lotes com testada para os trechos dos logradouros cujos eixos constituem a linha perimetral.

$\S 2$ ㅇ Não são igualmente permitidas edificações de madeira nos lotes com testadas para a Av. Paraná entre o eixos da Rua Brasil e Rua Curitiba; Rua Marechal Deodoro, entre os eixos da Rua Rio Grande do Norte e Rua Amapá; Rua Guaporé entre os eixos da Rua Rio Grande do Norte, Rua Amapá; Rua Quintino Bocaiuva entre os eixos da Rua Mossoró e Rua Antonina; Av. Higienópolis entre os eixos da Rua Espírito
} 
áreas comerciais e residenciais mais valorizadas, de alto padrão, nas proximidades da Av. Higienópolis.

Até a década de 1950, portanto, as ocupações irregulares e precárias foram abordadas pela legislação municipal com este caráter de erradicação. A partir da década de 1970, quando cresce significativamente o número de favelas em Londrina, o início das atividades da Cohab é também o princípio do enfrentamento da informalidade. Neste período ainda não existiam publicações de documentos oficiais sobre este tema, porém o livro lançado por Gavetti ${ }^{159}$ em 1998 permite interpretar a forma como era visto, sobretudo pela Cohab-LD sob sua administração, o problema da informalidade da ocupação do espaço urbano pela população de baixa renda.

\section{Os discursos e a construção de verdades}

Outros documentos oficiais que contém dados de levantamentos da precariedade habitacional em Londrina foram analisados para compreender os critérios e parâmetros que levaram às decisões de remover ou regularizar os assentamentos/ocupações.

Iniciados os trabalhos da Cohab-LD, os relatos mostram como o "desfavelamento" se tornou uma prática da companhia para além da sua função de comercialização de unidades habitacionais. Quando Gavetti assumiu a presidência da Cohab-LD, mais de cinco anos depois da criação da companhia, existiam apenas uma ata e alguns "bens imóveis"160.

Segundo Gavetti, a problemática das favelas chegou até a Cohab-LD quando estavam viabilizando o primeiro Conjunto Habitacional, a partir de uma reportagem

\footnotetext{
santo e Rua Alagôas; Rua Duque de Caxias entre os eixos da Rua Espírito Santo e Rua Jacarézinho e todos os lotes zoneados nas categorias RI-A, RI-B e RI-O.

159 O livro "A dignidade política administrativa. Por que tem que ser assim?", de Nelson Gavetti (1998) que presidiu a Cohab-LD de 1969 a 1973, traz relatos da sua experiência pessoal na gestão pública recuperando o início dos trabalhos da Cohab-LD. No livro, o autor conta que nesta gestão foram iniciados os trabalhos da Cohab-LD a partir de uma difícil disputa (por questões partidárias) no BNH.

160 Gavetti (1998).
} 
sobre a ameaça de despejo dos moradores da Favela Caixa Econômica (ocupação em um terreno da Caixa Econômica Federal) ${ }^{161}$.

O relato de Gavetti sobre a primeira negociação em que a Cohab-LD participou para solucionar um problema relacionado à favela mostra, primeiro, a percepção da favela como algo que prejudica uma imagem, algo ruim, depreciado. Além disso, a fala revela o início de uma prática realizada ao longo de toda a história da Cohab-LD, a negociação com os proprietários para a compra dos terrenos ocupados.

Segundo os relatos pessoais, o envolvimento de Gavetti com esta temática teve também um viés pessoal, um incômodo com relação às condições da vida na favela que o acompanhou após "a chance de conhecê-la por dentro"162. Depois da primeira visita ele conta que voltou "(...) à Cohab traumatizado, desconcertado e muito pensativo." 163. Segundo Gavetti, depois desta primeira experiência passou a "visitar favelas e identificar o que acontecia"164.

Gavetti dedicou um capítulo do livro em defesa da prática do desfavelamento, em que segue (pelo olhar do outro) descrevendo (negando), de certa forma rebaixando aquela realidade.

É impressionante como o ser humano desqualifica-se em níveis tão inferiores. Os casebres, ranchos, tugúrios, seja lá o nome que queiram dar, é de indignação. São montados com tábuas, caibros, sarrafos, chapas de cimento-amianto, fibra ou compensado, cobertura com telhas, zinco, resto de tábuas, quer dizer - foi usado todo entulho

\footnotetext{
${ }^{161}$ Como se tratava de cerca de 400 famílias o prefeito, dimensionando o impacto social que seria gerado pela ação, iniciou contato com os moradores. Enquanto isso, Gavetti procurou a CEF como presidente da Cohab-LD. Ele relata: "Franco e direto, explanei o seguinte: - O terreno favelado em questão é da Caixa; os favelados, um problema Social, com uma prerrogativa: a favela era conhecida como "Favela da Caixa Econômica", o que prejudicaria a imagem que a Caixa tinha de Banco Social. Como o Município não possuía orçamento para bancar a desocupação, solicitei uma desapropriação do imóvel em caráter amigável e com valor simbólico. O Gerente entrou em contato com os superiores para aprovar nosso pedido. A resposta foi imediata e positiva. A avaliação era bastante simbólica. Quando comuniquei ao prefeito o acontecimento, quase não acreditou. Reuniu a Câmara em convocação de emergência, sendo aprovada a verba para a negociação. No dia 7 de outubro consolidou-se toda a operação, e o terreno da Caixa, por ser de interesse social-habitacional, foi entregue à Cohab-LD" (Gavetti, 1998, p.47/48 grifo no original).

${ }^{162}$ Gavetti (1998, p.49).

163 Gavetti (1998, p.50).

${ }^{164}$ Gavetti (1998, p.51).
} 
encontrado pelo caminho. Piso de terra apiloado - pé direito pouco além da altura de uma pessoa; sem energia elétrica, sem água potável, sem endereço. Um cômodo servindo de sala, cozinha, quarto, privada, tudo em comum. Convivem também com eles a promiscuidade, as endemias, o analfabetismo, a inanição, fatores esses que os levam com facilidade à descrença por tudo e a desvalorização de suas próprias vidas. Geralmente o favelado é pobre em recursos financeiros, mas rico em filhos. Chegam a morar três, quatro, cinco, seis pessoas empilhadas em um barraco. Existem fatos diversos. Em um constatei alguém deitado sobre um estrado de péssima montagem; pior ainda era o aspecto de seu ocupante, e fiquei sabendo que ali ele estava já por uns cinco anos sem levantar-se, sem tratamento, sobrevivendo. Em outra favela, meninas-moças usavam de todos os meios disponíveis para conseguirem aparência mais sociável; queriam ser gente. $\mathrm{O}$ que mais chocava eram as crianças abandonadas à sua própria sorte, as vítimas inocentes ${ }^{165}$.

Argumenta no texto sobre os fatores que acredita que foram os responsáveis pelo surgimento de favelas em Londrina, primeiramente o êxodo rural gerado pela ânsia por melhores condições de vida devido às mudanças na produção agrícola na região. Para Gavetti, a instalação na favela é uma medida provisória devido às dificuldades de se inserir no aluguel, mas que pode se tornar uma situação permanente (de forma irresponsável) por ser mais econômica.

Na descrição da vida na favela a partir de sua percepção, o autor enfatiza os aspectos negativos e aborda a favela como o ônus do desenvolvimento. Por isso, conta que a partir do levantamento feito pela Cohab-LD na década de 70 - que apontou a existência de nove favelas - foi elaborado por eles (diretoria e corpo técnico da CohabLD) um programa de desfavelamento. Ele conta que essa ideia foi apresentada ao BNH que teve recepção positiva para a implantação do programa. Argumenta também que "a própria comunidade sentiu a grandiosidade do Programa e deu um apoio e um grande incentivo na continuidade do mesmo"166.

Desse modo, teve início o programa de desfavelamento. A primeira favela escolhida para ser erradicada foi a favela do Bom Retiro, que continha um número menor de famílias o que facilitaria a primeira experiência, dentro outros motivos. As

165 Gavetti (1998, p.53).

${ }^{166}$ Gavetti (1998, p.58). 
famílias foram removidas para o Conjunto Habitacional Barravento. Após a mudança, os barracos foram queimados pelo Corpo de Bombeiros para evitar a reocupação.

As famílias que foram atendidas pelo programa de desfavelamento receberam cuidados de estudantes de medicina que "visitaram os barracos dando toda orientação necessária para os favelados, principalmente no tocante à parte de higiene, para o processo da mudança" 167 . Segue descrevendo os trabalhos da Cohab-LD com o objetivo do "desfavelamento",

O desfavelamento prosseguia, o Conjunto Pindorama, 1972, construído no próprio local onde existia a Favela do Grilo, seus moradores em parte já alojados em casas avulsas em definitivo, outros provisoriamente retornavam ao local, mas nas casas edificadas. Em seguida, duas favelas, Fraternidade e Pito Aceso, também para o Pindorama foram transferidas totalmente. Conjuntos esses que, além das habitações, contava com um Centro Comunitário destinado às tarefas de integração dos novos moradores na sociedade. Este Centro era constituído de uma espécie de anfiteatro, com costura e economia doméstica ${ }^{168}$.

O relato sobre as ações de "desfavelamento" da Favela Fraternidade demonstra aspectos do autoritarismo que permeou o discurso e as ações. No início da fala diz que essa ocupação era próxima ao centro da cidade e que os moradores "achavam-se no direito de Usucapião do terreno (...)"169. Os motivos da remoção são evidentes. "Nosso objetivo era tirar aquelas vidas do submundo e a mancha na paisagem urbanística da cidade" 170 .

Gavetti conta que foi advertido com relação ao modo autoritário e o uso de violência (ainda que não fosse física, mas principalmente psicológica): "Nelson - você está louco, com todo esse barulho, essa movimentação, esse fogo, você vai traumatizar essa gente...!". A resposta parece carregar a ideia dos fins que justificam os meios:

\footnotetext{
167 Gavetti (1998, p.60).

168 Gavetti (1998, p.66, grifo no original).

169 Gavetti (1998, p.67).

${ }^{170}$ Gavetti (1998, p.67).
} 
"Traumatizar quem? Quem mora nisso aqui não tem lugar para mais traumas; pior, eles conhecem só essa linguagem"171.

Em seu livro Gavetti segue defendendo e justificando as ações de "desfavelamento" e descreve com tons de orgulho os agradecimentos de representantes dessas comunidades.

Sem a pretensão de recuperar todo o conteúdo do relato do primeiro presidente (ativo) da Cohab-LD, o que procuro mostrar é que a intenção da erradicação que está fortemente presente no discurso de Gavetti e que, já visto, está incorporado na legislação municipal e permeia o discurso presente nos documentos oficiais que apresentam diagnósticos da situação habitacional em Londrina. O número de favelas após estas primeiras ações descritas aumentou exponencialmente durante a década de 70 e, apesar da ideia de erradicação ficar cada vez mais distante da realidade possível, ela passa a ganhar novas razões e justificativas para ações pontuais. De manchas na paisagem, conflitos fundiários a impactos ambientais, as favelas são abordadas como o negativo, o que denigre, o que impacta e causa ônus.

O levantamento realizado na década de 90 pelo recém fundado Instituto de Pesquisa e Planejamento Urbano de Londrina - IPPUL - foi o primeiro documento sistematizado sobre a situação habitacional do município ${ }^{172}$. Este documento traz informações sobre a existência de favelas na área urbana e nas análises demonstra como o poder público encara esta questão. Nesse documento a presença das favelas é analisada na argumentação sobre a estruturação da paisagem urbana e da dinâmica do mercado imobiliário. Destaca-se nestas análises que a visão do poder público sobre a existência de favelas muda após a virada da década de 1970.

As favelas são denominadas como "pontos de favelização", e a interferência na estrutura da paisagem se dá pela localização das favelas nos fundos de vale. São diferenciadas as favelas-aglomerados, aquelas com mais de 50 barracos, das favelasnúcleos, com menos de 50 barracos. A partir desta definição, "a localização de dezenas

\footnotetext{
${ }^{171}$ Gavetti (1998, p.68).

172 O IPPUL foi fundado em 1993, durante a gestão de Cheida (PT). O documento que sistematizou o levantamento sobre a demanda habitacional em Londrina foi publicado em 1996.
} 
de pontos de favelas em praticamente todos os quadrantes da cidade, geralmente em áreas públicas, próximos aos vales/ córregos"173.

O que está colocado é que até a década de 1970 as favelas não estavam interferindo na dinâmica do mercado imobiliário, dados os limites da expansão da malha urbana e, por isso, eram "toleradas". Quando estes terrenos passaram pelo processo de valorização imobiliária, as favelas passam a ser vistas como um problema a ser erradicado ${ }^{174}$.

Por isso, a partir deste período alguns conjuntos habitacionais começam a ser produzidos com a finalidade de "abrigar pessoas vindas de favelas" ${ }^{175}$ dando início às ações de "desfavelamento". As remoções destas favelas aconteceram para assentamentos e conjuntos habitacionais localizados também na zona leste. No documento consta que a maior parte das favelas removidas estavam em áreas particulares na zona leste próximas às margens da rodovia, e na porção sul, região mais valorizada da cidade.

Este documento é o único que aborda e remoção de favelas fazendo relação com a dinâmica do mercado imobiliário. Como há várias menções à desigualdade ocasionada pelo sistema capitalista, é possível concluir que a equipe que elaborou o diagnóstico apresentava uma leitura crítica da desigualdade e procurou, superficialmente, incorporar essa visão no documento, porém sem aprofundamento.

Outro documento bastante citado é o diagnóstico PEMAS - Plano Estratégico Municipal de Assentamentos Subnormais, elaborado no Programa Habitar Brasil-BID. Esse programa, financiado pelo Banco Interamericano de Desenvolvimento - BID -, teve como objetivo estimular os municípios a destinarem recursos para urbanização e

\footnotetext{
173 IPPUL (1996, p.08).

174 IPPUL (1996, p.29). No trecho original: "A existência de favelas, por longo período foi tolerada pelo poder público por não possuir recursos para empreender uma ação globalizante, pelo fato de os terrenos não possuírem importância no mercado imobiliário e, ainda, porque as favelas eram centros de interesses político-eleitorais. Contudo, a partir da década de 70, a favela passa a constituir-se em uma grande preocupação para a administração pública, dado o valor que os terrenos por elas ocupados adquirem no mercado imobiliário. Sem que se questionasse o porquê de seu surgimento, o que seria reconhecer as falhas do sistema capitalista, as favelas passam a ser consideradas "disfunção do sistema" e, como tal deveriam ser erradicadas. Criam-se assim, programas de com vistas à remoção do "problema".

175 IPPUL (1996, p.14).
} 
regularização de assentamentos subnormais, além de se atualizarem em termos de regulamentação da gestão urbana visando o aumento da eficiência municipal ${ }^{176}$. Posteriormente este programa passou a ser financiado com recursos do PAC.

Como requisito para acessar os recursos do programa, os municípios deveriam elaborar e implementar o PEMAS que, além de apresentar o diagnóstico da precariedade municipal, definiu também as ações que seriam realizadas. Neste documento a abordagem muda: não se fala em mercado imobiliário e paisagem/imagem da cidade. A ênfase é dada aos números e percentuais que visam ilustrar a situação da precariedade habitacional municipal. As conclusões enfatizam o grave contraste social.

Isso nos permite afirmar que Londrina tem mais da metade de sua população total na faixa de pobreza e que um grande número de famílias está na condição de miserabilidade. Dessa forma os contrastes sociais se evidenciam e se agravam, possibilitando a conclusão de que é alto o índice de população excluída em nosso município ${ }^{177}$.

Os dados apresentados apontam logo no início do documento que o percentual de investimento municipal da área de "Habitação e Urbanismo" são significativamente inferiores, ficando em torno de $10 \%$ do investimento nas demais áreas como “Administração e Planejamento”, “Educação e Cultura”, entre outros ${ }^{178}$.

Enquanto no documento do IPPUL se usa o termo "favela" para nomear as ocupações irregulares de baixa renda, com relação às ocupações irregulares, os termos utilizados são "invasões" ao longo de todo o texto.

No entanto, o documento apresenta uma conceituação utilizada pela Cohab que diferencia as formas irregulares de ocupação do solo em "favela urbanizada", "assentamento" e "ocupações irregulares". As três definições têm semelhanças, principalmente referente às condições de precariedade das habitações. O que as difere

\footnotetext{
${ }^{176}$ Cordeiro (2006).

177 PEMAS (2002, P.20).

178 PEMAS (2002, P.20).
} 
entre si é a origem das ocupações e as possibilidades - entendidas pela Cohab-LD - de regularização. No caso das favelas e das ocupações irregulares a origem é "espontânea", ou seja, organizada pelos próprios moradores, enquanto os "assentamentos" foram ocupações organizadas pela Cohab-LD para reassentar famílias removidas de outras ocupações. Ao mesmo tempo, as favelas urbanizadas e os assentamentos podem vir a ser regularizados, enquanto as ocupações irregulares, em função do local onde elas ocorreram, áreas particulares e fundos de vale que, na concepção da Cohab-LD, não podem ser regularizadas.

O principal apontamento sobre o documento é em relação às ocupações das áreas de fundos de vale. Sobre as "invasões" em áreas particulares, informa-se que estas áreas são oferecidas para a Cohab-LD a preço de mercado, como forma de "negociação".

\begin{abstract}
Nos dias atuais vem ocorrendo invasões em áreas públicas, principalmente nos fundos de vale - zonas de preservação permanente às margens dos corpos d'água, municipalizados quando das aprovações dos loteamentos, exigindo-se na aprovação do projeto a urbanização dessas áreas. Após a liberação do loteamento a manutenção das áreas públicas ficam na responsabilidade da Prefeitura, porém o órgão responsável pela manutenção não possui equipamentos e recursos humanos suficientes para atender a todas áreas públicas, deixando-as vulneráveis a essas invasões ${ }^{179}$.
\end{abstract}

No documento argumenta-se que a prefeitura não dá a devida manutenção para estas áreas, "deixando-as vulneráveis a essas invasões". A justificativa colocada para a falta de manutenção é que "[a prefeitura] não possui equipamentos e recursos humanos suficientes para atender a todas áreas públicas deixando-as vulneráveis a essas invasões" ${ }^{\prime 180}$. Ainda, ao longo do documento, a falta de controle do fluxo de migração de trabalhadores para a cidade também é apontada como causa para o problema. Em nenhum momento a dinâmica (preços) do mercado imobiliário e as condições de trabalho precário, desemprego e baixos salários são mencionados. Ainda sobre essa lógica,

\footnotetext{
179 PEMAS (2002, p.31)
}

180 PEMAS $(2002$, p.31) 
Com a falta de conservação e sem a participação comunitária para a preservação desses vales, eles vão se tornando locais atrativos para vândalos, drogados e até para instalação de moradias, haja vista o mapeamento das invasões na cidade e seu adensamento, processo hoje quase que irreversível dadas as condições administrativas e financeiras atuais do Município ${ }^{181}$.

Neste trecho, ao colocar a ocupação para fins de moradia junto com outras atividades ilícitas criminaliza a favela e, ainda, o uso da preposição "até" indica que a gravidade da ação é maior do que das demais ações citadas. Outro indicativo de criminalização das ocupações pode ser observado da colocação "Na maioria das vezes um grupo invade uma determinada área à espera de que a Cohab-LD regularize tal situação, mesmo tendo conhecimento de que o uso da área seria ilegal”182.

Todas ocupações irregulares identificadas no levantamento e que apresentaram graus de precariedade habitacional foram listadas no documento, apontando número de lotes e número de pessoas. Foram identificados 59 núcleos "subnormais", porém dois no município de Cambé (área conurbada com Londrina) foram englobados junto ao núcleo de Londrina nesta porção territorial e considerados como um "grande aglomerado subnormal".

As considerações feitas sobre o resultado do diagnóstico evidenciam a invisibilidade da precariedade habitacional, mesmo no âmbito da Companhia de Habitação.

O resultado foi um grande 'susto' para os próprios técnicos integrantes da equipe, inclusive para os da $\mathrm{COHAB}$, acostumados a conviver com esta realidade: eram 9532 famílias perfazendo um total 47706 pessoas, vivendo em situação não só subnormal, mais a maioria em condições subumanas. Mais assustador foi quando se constatou que este dado representava pouco mais que $10 \%$ da população total do município. Esse trabalho planilhado e mapeado, culminou com o perfil subnormal de Londrina, primeira ação deste trabalho, que acabou por 
chocar inclusive a opinião pública, tendo sido objeto de diversas matérias jornalísticas na época ${ }^{183}$.

Quanto aos critérios para a classificação dessa "subnormalidade" (e até condições "subumanas") foram definidos: "área de reserva permanente invadida; degradação social; contenção do espaço imediato; degradação ambiental; facilidade de regularização; comunidade organizada; e renda familiar". Os critérios não são detalhados, assim como os dados levantados. Foi dada uma pontuação em cada categoria a fim de hierarquizar as ocupações, e identificar as prioridades de intervenção.

Essa transformação das informações coletadas em índices (números) oculta uma série de questões, transformando o diagnóstico em informações quantitativas, perdendo as especificidades de cada território que só poderiam ser compreendidas a partir de uma análise qualitativa da situação.

O que está colocado é que "verificou-se também, que o risco social está diretamente ligado a questão da renda e faz uma interface direta com a degradação ambiental" esta, por sua vez, percebe-se pela pontuação dada nas categorias, não está diretamente relacionada à ocupação do fundo de vale, já que núcleos que têm fundos de vale ocupados tiveram pontuação muitas vezes menor no item da "degradação ambiental" do que núcleos que não têm fundos de vale ocupados.

Nesse sentido, as remoções são apontadas como a única solução possível para as ocupações que estão em áreas de preservação permanente. Mas, ainda, é importante salientar que a preservação da faixa sanitária garante a extensão de 60m de vegetação nas margens dos fundos vale, ou seja, algumas dessas ocupações não chegam a ocupar os $30 \mathrm{~m}$ de APP previstos pela Legislação Federal ${ }^{184}$.

\footnotetext{
183 PEMAS (2002, p.37).

${ }^{184}$ Ainda que a Lei Federal - Código Florestal Lei no 12.651/2012 e Resolução do Conama no 369, de 28 de março de 2006 - permita a supressão da APP para os casos de regularização fundiária, é necessário verificar a situação do solo como inclinação e possibilidade de deslizamento para garantir a segurança da ocupação nestas áreas. Entretanto, nenhum dos levantamentos realizados em Londrina traz essas informações.
} 
Vale destacar uma possível distorção dos dados. Para "quantificar e qualificar" a demanda por moradias, esse diagnóstico analisado utilizou primeiramente um banco de dados coletados para cadastramento das famílias em um programa municipal (Poupalar). Neste banco de dados as famílias preencheram um formulário em que elas detalham preferências com relação à moradia e a região onde gostariam de morar. É sobre a abordagem feita com relação a este último que gostaria de chamar a atenção. Quando esses dados foram tabulados, a zona leste (área diagnosticada como a que concentra o maior número de aglomerados subnormais em diferentes momentos) foi indicada pelo maior número de famílias (35\%) como mostra o gráfico.

Entretanto, no documento, esta informação é considerada como "demanda influenciada" sob o argumento de que este é um "fato até então nunca detectado", apesar de nunca ter sido levantado e sistematizado. O termo "influenciada" é adotado pois argumenta-se que o primeiro empreendimento do programa Poupalar foi lançado na zona leste.

De fato, na ficha de cadastro o Centro não foi colocado como opção, e a Zona Leste de Londrina é a região mais próxima ao centro, o que pode ser uma das razões para o maior percentual em relação às demais regiões. Esta informação foi, portanto, descartada e substituída pelo local atual de moradia dos cadastrados no programa, o que gerou a chamada "demanda real".

Gráfico 4 - Demanda por moradia nas regiões da cidade de Londrina

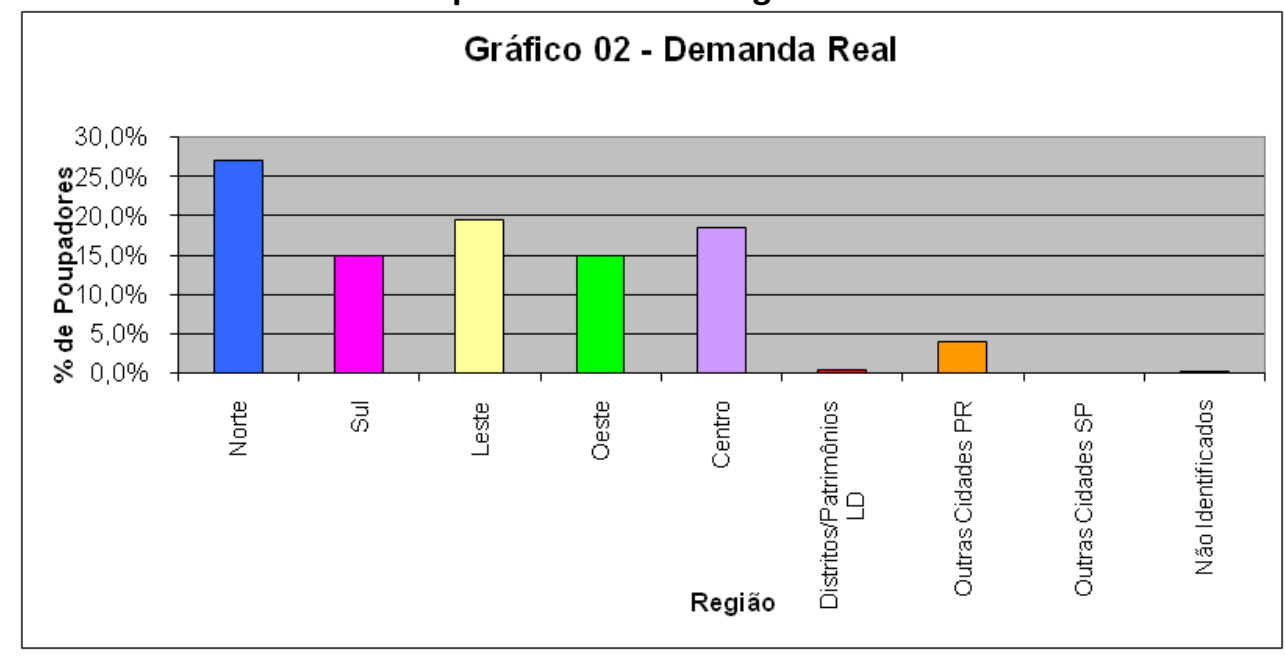

Fonte: PEMAS (2002). 
Ao incluir o centro, fica evidente que a preferência pela zona leste é devida à proximidade com o centro da cidade. Desse modo, as opções aparecem dissolvidas e a zona norte desponta. Essa iniciativa legitima a zona norte como o lugar dos pobres na cidade de Londrina.

A incapacidade da Cohab-LD em solucionar o problema habitacional é justificada no diagnóstico com o argumento de que a Companhia assume toda a responsabilidade sobre a precariedade habitacional, enquanto sua função seria apenas a de ofertar programas de acesso à moradia. Entretanto, foi mostrado que o "desfavelamento" foi incorporado como ação da Cohab-LD desde sua fundação.

O principal argumento é de que a Cohab-LD não tem recursos para realizar todas as ações necessárias para solucionar essa problemática habitacional. A única fonte de recursos garantida pela Prefeitura Municipal, principal acionista da Companhia ( $99 \%$ das ações) é o "aumento de Capital Social, através da integralização, por meio de terrenos". Essa informação é importante para a compreensão da visão da Companhia de que seu capital está investido em terrenos.

Além dos indícios de criminalização dos ocupantes, parece haver uma tentativa de eximir o município de culpa pela situação de precariedade diagnosticada e, ainda, reforçar o "esforço" feito pela Cohab-LD nas tentativas de solução, e dá a entender que se a prefeitura tivesse recursos para gerir os fundos de vale estes não seriam ocupados.

Não deve haver orgulho em declarar: "moro em um assentamento subnormal". Ninguém coloca a vida de sua família e principalmente de seus filhos, sem o pesar do presente e o sonho do futuro. Não estamos lidando só com números, estatísticas e cifras. Estamos lindando com gente, com pessoas, com homens, mulheres e crianças. Estamos lidando com expectativa de vida, com o direito a cidade, direito este a princípio, igual para todos. A administração municipal não se orgulha em ter tantos problemas ligados a subnormalidade, nem tantos cidadãos nesta situação, e muito menos de na maioria das vezes estar completamente impotente para socorrer, solucionar e prevenir ${ }^{185}$.

185 PEMAS (2002, p.64). 
Nesse sentido, as soluções do Programa Habitar Brasil/BID correspondentes ao diagnóstico do PEMAS resultaram em duas etapas de intervenção, o HBBI e HBBII. No primeiro a área de reassentamento das famílias foi denominada Jd. Primavera I e no segundo foi denominada de Jd. Primavera II. A primeira intervenção ocorreu na Poligonal Turquino-Maracanã, onde as intervenções englobaram a urbanização do assentamento precário, remoção das famílias dos fundos de vale, aquisição da propriedade particular do Jd. Maracanã para viabilizar a regularização dos ocupantes e a implantação de equipamentos públicos ${ }^{186}$.

A segunda área de intervenção, correspondente ao HBB II, foi o fundo de vale da Rua Ana Caputo Piacentini, conhecido como Vale da Lua, o fundo de vale da Fazenda Primavera, conhecido como Vale do Sol, e o Jardim dos Campos que compunham (e novamente compõem, pois foram reocupados) aglomerado de ocupações irregulares localizados predominantemente em fundos de vale. Todas as famílias que estavam localizadas nos fundos de vale foram removidas para um terreno próximo denominado Jd. Primavera II. Nesta etapa o fundo de vale foi revitalizado, com a demolição das casas, retiradas dos entulhos e implantação de equipamentos de lazer. Toda a área que foi desocupada neste programa encontra-se novamente ocupada.

Em 2011 foi aprovado o Plano Local de Habitação de Interesse Social de Londrina - PLHIS. Uma das etapas do PLHIS também corresponde ao diagnóstico da situação habitacional do município, mas utiliza-se a metodologia da Fundação João Pinheiro para qualificação do déficit, apesar dos dados serem quantificados no final. No diagnóstico do PLHIS as áreas foram detalhadas uma a uma, com mapeamento e com histórico superficial das ocupações. Apesar destas informações mais pontuais (mesmo que generalizando a ocupação), no final a análise foi feita a partir dos números totais, homogeneizando as ocupações a partir da classificação básica relacionada à origem das ocupações e às possibilidades de regularização (em oposição às áreas de remoção).

${ }^{186}$ Cordeiro (2006). 
Este documento também aborda o "desfavelamento" como solução coerente e possível para a situação das ocupações irregulares, e aponta que as "invasões" continuaram "apesar" dos projetos de "desfavelamento" empregados.

A contextualização geral sobre as ocupações é construída a partir de um histórico da atuação da Cohab-LD no campo do "desfavelamento" e mostra que grande parte das ocupações analisadas correspondem às primeiras ocupações da cidade, na zona leste.

Importante destacar que a única ocupação irregular em área de fundo de vale que foi urbanizada com supressão de parte da área de preservação permanente é o Jardim Rosa Branca, que foi a primeira ocupação irregular em área de proteção ambiental da zona leste. A urbanização aconteceu em 1994 com recursos da Cohapar.

Outro apontamento do diagnóstico que deve ser destacado para a análise é quanto às famílias removidas do Jd. Rosa Branca para viabilizar a urbanização da área e foram realocadas no Jardim Santa Fé, um dos assentamentos atendidos no atual (2013) Programa de Regularização Fundiária e que, em 2011, também foi alvo de remoções para o Residencial Vista Bela. Isso mostra como o reassentamento das famílias de forma precária dá origem a um novo núcleo que, posteriormente, se torna alvo de novas ocupações nas áreas remanescentes que, posteriormente, terão famílias removidas para outro local, e assim por diante.

No documento do diagnóstico do PLHIS, a Zona Leste foi apontada como a região que concentra o maior número de assentamentos precários e ocupações irregulares de Londrina, ou seja, é a região que teve o maior número de assentamentos promovidos pela Cohab-LD a partir da remoção de famílias de favelas, bem como é a região que teve o maior número de áreas ocupadas "espontaneamente" por famílias de baixa renda, o que mostra inclusive uma possível relação entre estas ações.

Ainda especificamente sobre a zona leste, o diagnóstico reforça que grande parte das ocupações se encontra em áreas de fundos de vale. Sem diferenciá-las entre si, as ocupações irregulares passam a ser abordadas como ocupações em áreas de riscos ambientais. Os "riscos ambientais" não são explicitados, definindo apenas que se trata de ocupação em fundo de vale, APP ou encosta íngreme, bem como não são 
apresentados os critérios para esta classificação. De qualquer modo, todas estas ocupações (17) são apontadas como "ocupações irregulares cuja população deverá ser removida e realocada" ${ }^{187}$.

Sobre o Morro do Carrapato, única área particular ocupada, no documento é dito que "não houve acordo com o proprietário e, sendo assim, as famílias deverão ser removidas integralmente do local" ${ }^{188}$, mesmo sem o pedido de reintegração de posse. Isso mostra que, apesar do constante argumento de que a Cohab-LD não tem recurso nem pessoal suficiente para traçar e executar soluções, busca, por vontade própria, trazer solução para o conflito fundiário que pode ser resolvido diretamente entre ocupantes e proprietário antecipando, inclusive, uma decisão favorável ao proprietário. Esses fatos dão pistas da postura da Cohab-LD em favorecer os interesses dos proprietários fundiários em detrimento dos interesses e direitos dos ocupantes.

As indicações para remoção partem apenas da premissa da ocupação em fundo de vale, sem apresentar uma investigação das condições locais. Esta forma de abordagem oculta, inclusive, o fato de o Jd. Rosa Branca ser uma ocupação de fundo de vale que foi urbanizada e está apta a ser regularizada. As soluções apontadas consideraram apenas os dados das ocupações que não serão removidas.

Em 2012, outro "convênio" com o BID demandou a realização de novo diagnóstico habitacional, mas agora submetido ao diagnóstico das condições ambientais da cidade de Londrina. Isto porque um dos eixos ${ }^{189}$ de ação previstos neste programa é a "recuperação ambiental de áreas degradadas dos fundos de vale".

Analisando o "Componente 1: Recuperação e revitalização ambiental dos fundos de vale", o direito ambiental aparece como soberano ao direito à moradia na concepção do principal objetivo deste componente, de "intervir nos fundos de vale a fim de remover a população em situações de risco, recuperar as áreas degradadas, e revitalizar

\footnotetext{
187 PLHIS, Etapa V (2011, p.140).

188 PLHIS, Etapa V (2011, p.140).

189 O PRI-BID (2012) que corresponde ao Plano de Reassentamento Involuntário de Londrina, previa quatro Componentes do Programa: Componente 1: Recuperação e revitalização ambiental dos fundos de vale; Componente 2: Mobilidade Urbana; Componente 3: Revitalização do Centro Histórico; Componente 4: Modernização da Gestão Municipal".
} 
as margens de rios e córregos na área urbana e prevenir novas ocupações irregulares" ${ }^{\prime 190}$.

Novamente, a justificativa do "risco" em que se encontra a população é colocada sem a definição do que se considera como "risco". Quanto às ações previstas neste componente, são apontadas

(...) realocação e provisão de unidades habitacionais básicas para 231 famílias que atualmente moram em áreas de risco e não tem acesso a programas de financiamento de moradias; a recuperação e requalificação de $383.633,14 \mathrm{~m}^{2}$ de fundos de vale e a revitalização de 1.062.463,37 $\mathrm{m}^{2}$ do Parque Linear Ribeirão Cambé através de ações de urbanização/implantação de mobiliário urbano, revegetação/recuperação de Áreas de Preservação Permanente (APPs) e a estabilização de solo de trechos críticos ao longo de $30 \mathrm{~km}$ de afluentes do Ribeirão Cambé (sobretudo nos locais em que ocorrem desmoronamento/erosões de margem e nas confluências de afluentes com o Cambé que apresentem forte interface com o sistema viário) ${ }^{191}$.

Destaco em primeiro lugar que os fundos de vale são abordados como "áreas de risco" sem o esclarecimento de que tipo de risco está se referindo. A "recuperação e requalificação" dos fundos de vale considerados degradados também não é detalhado em termos de ações. Apesar da recuperação ambiental ser o principal foco deste componente não são apresentados estudos das condições dos córregos e dos fundos de vale em termos de nível de poluição e desmatamento, por exemplo.

Sobre este aspecto, na caracterização ambiental da cidade, o texto chama a atenção para a relação dos rios da área urbana e as bacias hidrográficas responsáveis pelo abastecimento de água da cidade. Destaca-se que "as bacias do ribeirão Cambé (onde se localiza o parque linear do Igapó) e do Ribeirão Cafezal são responsáveis por $40 \%$ do abastecimento municipal e que o restante é captado do Rio Tibagi. O próprio documento argumenta que o Rio Tibagi tem sofrido fortes impactos decorrentes das atividades agroindustriais e urbanas (sabe-se que os impactos das atividades agrícolas e

190 PRI-BID. Relatório de Avaliação Ambiental (2012, p.12).

191 PRI-BID. Relatório de Avaliação Ambiental (2012, p.12). 
industriais são muito maiores que as atividades residenciais), entretanto, não são traçadas diretrizes para a ocupação e o uso do solo nas proximidades do Rio Tibagi.

Ao mesmo tempo, a "revitalização/urbanização/implantação de mobiliário urbano e revegetação/recuperação de Áreas de Preservação Permanente" previstas para o "Parque Linear Ribeirão Cambé" não engloba a remoção das famílias que residem nas margens do córrego e a demolição das construções dentro dos trinta metros de área de preservação permanente, provavelmente por se tratar de residências de altíssimo padrão e de um Clube de Lazer privado que têm sua situação legalizada por Lei Municipal.

Quanto aos resultados esperados, observou-se uma contradição em relação às ações previstas. No documento fica clara a dificuldade no encontro das áreas para destino das famílias removidas dos fundos de vale. Entre as áreas previstas, são apontadas várias áreas de praças para realocação das famílias. Ao mesmo tempo, dentre os "resultados esperados" são apontados o "aumento do número de áreas verdes" e "aumento nas áreas de lazer da cidade".

Das 6 áreas destino para Reassentamento das famílias, 4 são hoje áreas públicas sob o domínio do Município (3 praças e $1 \mathrm{SPL}$-Serviço Público Local) que estão passando por processo de regularização para este fim específico. No momento estão sendo desafetadas de uso público, para posteriormente serem repassadas à COHAB-LD com uso residencial de interesse social, para facilitar o processo de emissão das escrituras definitivas e CDRU - Concessão de Direito Real de Uso (conforme minuta em anexo). Esta estratégia será utilizada para os casos em que seja identificado que o reassentado já tenha recebido atendimento habitacional anteriormente, com subsídio do estado e tenha vendido o imóvel. Uma das áreas já é de domínio da COHAB-LD com finalidade para uso habitacional de interesse social ${ }^{192}$.

As remoções são abordadas no sub-componente "Fundos de Vale em Área de Risco". O título do componente indica que alguns fundos de vale estão localizados em área de risco, enquanto anteriormente os fundos de vale estavam sendo chamados de

192 PRI-BID (2012, p.17), grifo meu. 
áreas de risco. Esta confusão com os termos confunde a interpretação do que se considera área de risco e por quê.

Neste tópico, a zona leste é escolhida como a área prioritária para intervenção, "pela concentração de grande parte das famílias em áreas de risco" em detrimento, portanto, das ações previstas para as imediações dos Córregos Cambé e Cafezal.

No conteúdo do diagnóstico destaca-se que uma parte das ocupações dos fundos de vale já foi removida com os recursos do Programa Minha Casa Minha Vida, por isso são indicadas as demais áreas "eleitas pelo programa" que terão as famílias removidas, que passam a ser enquadradas como "beneficiários" do programa.

Para que a recuperação ambiental seja realizada, será necessária a realocação de famílias que se encontram nestas áreas selecionadas pelo Programa. Nestas áreas foram identificadas 231 famílias a serem atendidas, que estão relacionadas de acordo com as regiões onde residem $(\ldots)^{193}$.

A justificativa apresentada reforçando a necessidade de remoção argumenta que as famílias "encontram-se em áreas de risco social, ambiental e sanitário. São Fundos de Vale e Áreas de APP's impossibilitando a permanência das mesmas no local".

No entanto, afirma que "a relocação não é objetivo do BR-L1094, mas é objetivo do Sub-componente A1, uma vez que sem reassentar as famílias não existe possibilidade de recuperar ambientalmente os Fundos de Vale que elas ocupam". Por outro lado, aponta que o PLHIS apresentou no diagnóstico a condição de vulnerabilidade das famílias e que elas terão dificuldades em arcar com as taxas e cobranças inerentes à condição de regularidade. Argumenta-se, ainda, que as famílias deverão ser reassentadas preferencialmente na mesma região de origem, "evitando impacto dos deslocamentos". Provavelmente, nesse período, já havia a constatação dos problemas dos deslocamentos do PMCMV, como o retorno das famílias para muitas destas mesmas áreas que novamente são alvo de remoções.

193 PRI-BID. Relatório de Avaliação Ambiental (2012, p.45). 
O que está colocado sobre a recuperação das áreas ocupadas é apenas relacionado à implantação de equipamentos de lazer, dar uso e embelezar, não é discutida a recuperação do córrego. Essas ações também são apontadas como prevenção à novas ocupações, o que não se comprovou na experiência do HBB/BID em 2002.

O modelo proposto no Plano do HBB Brasil - BID marcou a política habitacional da gestão petista da década de 2000. Nessa mesma gestão, houve iniciativa de promoção da regularização fundiária (apenas a fase de titulação) viabilizada pelo convênio com os cartórios e a elaboração da Lei Municipal no 9.866/2005.

Por volta de 2004, houve a tentativa de promover a regularização fundiária (durante o governo petista). Foi realizado o convênio da Cohab-LD com os Cartórios de Registro de Imóveis para baratear os custos de regularização, notadamente um dos principais obstáculos para concretizar a regularização fundiária. Como discutido, nestes casos, a gratuidade abrangia apenas as custas do registro (cinquenta reais) enquanto os emolumentos eram pagos pela Cohab-LD (cento e trinta reais). Segundo a funcionária que trabalhava com a regularização fundiária neste período, foi assim que a Cohab-LD começou a entregar os títulos das unidades habitacionais ${ }^{194}$.

\footnotetext{
${ }^{194}$ Nesse período, a partir da definição da área a ser regularizada pela Lei Municipal no 9.866/2005, o trabalho começava pelo setor de loteamentos, para depois ir para a comercialização, que consistia na forma de regularizar as unidades. O processo era realizado individualmente com cada família, coletando os documentos e regularizando a situação da comercialização dos lotes. A definição das áreas não era realizada dentro de um planejamento. A diretoria decidia qual área deveria ser regularizada e encaminhava para o setor de comercialização e loteamentos para iniciar a coleta dos documentos. Enquanto um funcionário coletava os documentos, outro funcionário fazia o "projeto" do loteamento. Depois dos trabalhos do setor de comercialização, retornava para ser efetuado o registro. Portanto, os trabalhos de regularização se restringiam aos setores de comercialização e loteamentos da Cohab-LD. Para a entrevistada, antes da Lei Federal no 11.977/2009, a principal dificuldade era compreender todos os mecanismos da burocracia legal: Lei de Registros Públicos, Código Civil, Provimentos das Corregedorias, etc. Durante este período, ela participou de eventos que visavam compreender as barreiras para a realização da regularização fundiária a partir de relatos das dificuldades enfrentadas por servidores em diferentes municípios. A partir desses dados, foram estabelecidas diretrizes que, para ela, foram contempladas na Lei Federal no 11.977/2009 por meio do esforço da desburocratização do processo, dando respaldo para os técnicos. Segundo ela, uma das grandes falhas era o não envolvimento da comunidade no processo de regularização, já que não havia a participação da equipe de assistência social da Cohab-LD. Um dos documentos que deveria instrumentalizar a Cohab-LD no final da década de 2000 para promoção da regularização fundiária, o Plano de ZEIS, elaborado em parceria com a Cohab-LD, não serviu na prática, segundo ela, por não conseguir "fazer a ponte entre o discurso e a prática". Apesar de considerar bom o trabalho, para ela ele não facilitava de fato o procedimento da regularização. A principal
} 
O fato de os assentamentos não serem regularizados resultou no desenvolvimento de um mercado ilegal de terrenos nessas áreas. Segundo relatos do presidente da Federação das Associações de Moradores de Favelas de Londrina ${ }^{195}$, formou-se uma quadrilha especializada nesse tipo de transação. Por outro lado, em 2001, em declaração de um funcionário da Cohab-LD em reportagem da Folha de Londrina fica clara a visão da companhia sobre esta questão, defendendo a remoção para assentamentos, apesar da resistência das famílias ${ }^{196}$.

A partir do estudo, observa-se que o "desfavelamento" é uma prática reproduzida na maior parte dos programas e gestões, visando a desocupação de áreas particulares, a extinção das favelas (alinhada ao discurso do BNH), e em outro momento foi utilizado para retirar famílias de áreas de fundos de vale e levadas para terrenos da Cohab-LD, onde recomeçavam a ocupação, sem investimentos em infraestrutura e construção de unidades habitacionais, formando os "assentamentos urbanos" promovidos pela Cohab-LD.

O discurso da remoção de favelas está presente nos documentos diagnósticos, no campo científico, com justificativas que variam entre o valor das terras, a preservação ambiental e as condições de risco das famílias. O desfavelamento esteve associado ao atendimento pela Cohab-LD. Justificado pelos discursos, legitimado pela legislação, e reforçado pelas práticas, o "desfavelamento" tornou-se uma verdade instituída197. Nesses mesmos documentos, as noções de risco e vulnerabilidade são abordadas de forma genérica, o que contribui para a justificativa da remoção como melhor alternativa.

referência sobre o tema é o Cartorário Lamana Paiva. Essa iniciativa foi possível tendo em vista que o Cartório Canziani tinha interesse em realizar e atender a normativa que garantia a gratuidade de parte do processo.

195 Folha de Londrina (1997). Disponível em: https://www.folhadelondrina.com.br/cidades/federacaodas-favelas-e-cohab-querem-por-fim-a-venda-de-lotes-33869.html. Acesso em 30/10/219.

196 Tratando de favelas e ocupações irregulares em fundos de vale, na reportagem é destacado que "não podem ser regularizadas e, consequentemente, o município não recebe nada pelos terrenos. 'O certo seria transferir todos para áreas de assentamento, mas a Cohab encontra muita resistência porque muitos não querem deixar aquela região onde já construíram uma vida e encontrar terrenos perto está cada vez mais difícil', aponta.". (Folha de Londrina, 2001). Reportagem disponível em: https://www.folhadelondrina.com.br/reportagem/favelas-concentram-carentes-desde-1966341194.html. Acesso em 30/10/219.

197 A construção de verdades com base nos discursos é discutida por Foucault (1998) na constituição do saber. 
Um aspecto que chama a atenção é o fato de que os assentamentos resultantes da remoção de famílias de outros núcleos, se tornam alvo de novas ocupações irregulares. $\mathrm{O}$ adensamento aumenta na medida que o assentamento se consolida como bairro. Como as ocupações atingem áreas institucionais e de fundo de vale, também se tornam alvo de medidas de remoção. Sendo assim, as áreas que foram destino das famílias transformam-se em áreas de origem de famílias a serem removidas para outros assentamentos ou conjuntos habitacionais. 


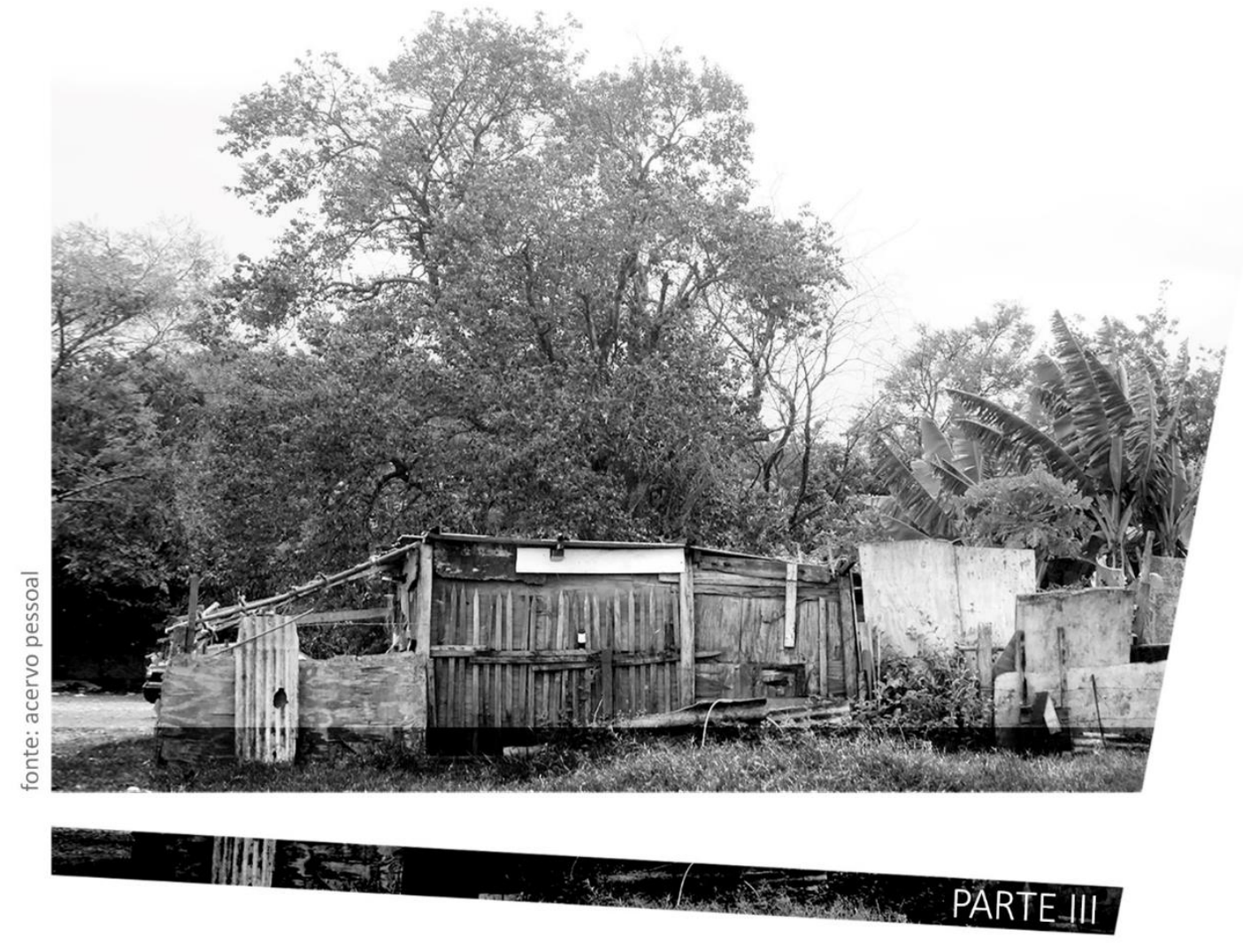




\section{Os Programas Habitacionais da Lei Federal no $11.977 / 2009$}

\section{A tentativa de construir uma política para a habitação}

Após um longo período de recessão das políticas habitacionais no Brasil, a eleição de Lula (PT) ${ }^{198}$ em 2002, que historicamente representou as reivindicações populares, fez crescer a esperança pela ampliação de políticas públicas voltadas à população de baixa renda, mas também gerou incômodo e resistência por parte dos setores conservadores da política e da sociedade brasileira. Como forma de equilibrar os interesses de uma das sociedades mais desiguais do mundo, alinhado aos termos do pacto $^{199}$ proposto pelo candidato do PT, os anos da sequência do partido no governo federal significaram a "acomodação de interesses e intenções conflitantes" 200 em uma agenda controversa.

No campo da Política Urbana, nos primeiros anos da promessa do "reformismo forte"201, a criação do Ministério das Cidades, que concentrou as secretarias de acessibilidade e programas urbanos, habitação, saneamento e mobilidade significou um aparente avanço na direção da agenda da reforma urbana. Segundo Rolnik (2015), no momento da criação do ministério as principais cadeiras foram ocupadas por membros do PT e por lideranças de movimentos sociais que tinham como foco a agenda da reforma urbana. A própria autora fez parte da equipe à frente da Secretaria Nacional de Programas Urbanos. Entretanto, após o enfraquecimento do PT decorrente dos escândalos de corrupção, em troca de apoio político o Ministério das Cidades foi

\footnotetext{
198 Luiz Inácio Lula da Silva (PT) foi eleito em 2002 e reeleito em 2006, exercendo o cargo de Presidente da República no período de 1ㅇ de janeiro de 2003 até 1 ㅇ de janeiro de 2011.

199 Na campanha de 2002, Lula acena para um pacto conciliador com a divulgação da "Carta ao povo brasileiro". Segundo Singer (2012) este pacto com setores conservadores para manutenção da estrutura econômica e política se efetiva durante o governo. A “Carta ao povo brasileiro" pode ser lida na íntegra em: https://www1.folha.uol.com.br/folha/brasil/ult96u33908.shtml. Acesso em: 23/10/2019. 200 Rolnik (2015, p.294).

${ }^{201}$ Segundo Singer (2012), o governo petista ficou marcado por implantar, no lugar do "reformismo forte" que se propôs, um "reformismo fraco" que foi resultado da diluição das reformas para evitar confrontos com os setores conservadores da sociedade.
} 
negociado e entra em uma sequência de gestões conservadoras que se distanciaram da proposta inicial.

Especificamente sobre a política habitacional, a proposta do governo baseava-se no Projeto Moradia elaborado durante a campanha presidencial. Após a criação do Ministério das Cidades e da composição do Conselho Nacional da Habitação, o governo deveria criar o Fundo Nacional da Habitação para concretizar o Projeto Moradia ${ }^{202}$ que ficou intitulado de PLANHAB na Secretaria de Habitação do Ministério das Cidades. Devido à resistência do Ministério da Fazenda, a criação do Fundo aconteceu apenas em 2006 e com algumas limitações ${ }^{203}$. Quando o Sistema Nacional de Habitação (SNH) e o Fundo Nacional de Habitação (FNHIS) estavam lentamente começando a funcionar, as alterações na equipe do Ministério das Cidades iniciaram a mudança do andamento da política habitacional.

Com relação à regularização fundiária de interesse social, a proposta era de dar apoio técnico e financeiro às equipes municipais e remover obstáculos jurídicos que historicamente inviabilizaram os processos de regularização fundiária. Para isso, foi criado o Programa Papel Passado, com o objetivo de fomentar programas de regularização, bem como capacitar os agentes municipais para esse fim.

A Carta Consulta foi o mecanismo criado para a obtenção dos recursos que foram liberados pelo programa a partir de 2004 até 2008 e, depois, novamente liberados em 2013.A edição lançada em 2016 não permitiu liberação de recursos, e procurou uniformizar a leitura dos assentamentos, em que cada prefeitura deveria indicar um assentamento para análise e regularização. Duzentos municípios participaram, e predominaram os municípios de médio e pequeno porte. A iniciativa de 2016 foi para criar parcerias entre o Ministério das Cidades e Universidades para compreender o perfil

\footnotetext{
202 Rolnik (2015).

${ }^{203}$ Rolnik (2015). Segundo Rolnik (2015, p.298) o FNHIS foi instituído como um fundo orçamentário e, por isso, ficou sujeito "ao contingenciamento e às rígidas regras de licitação. Além disso, o fundo contava com poucos recursos", limitando sua capacidade de atuação em comparação com a ideia original.
} 
da demanda pelos recursos do Programa Papel Passado e a capacitação institucional para implementá-lo204.

Em 2007, foi lançado o Programa de Aceleração do Crescimento (PAC) para promover o financiamento de grandes obras de infraestrutura, inclusive a urbanização de assentamentos precários e, portanto, previu o direcionamento de parte do seu recurso para a política habitacional ${ }^{205}$. Desse modo, o PAC e o FNHIS financiaram programas que, apesar de não resultarem em números tão amplos como viria a ter o PMCMV, atuaram priorizando famílias de baixa renda com a "produção habitacional e de lotes urbanizados, urbanização, regularização fundiária, melhoria habitacional, reforma e conversão de imóveis para habitação" 206 .

Nesse segundo momento do governo Lula, o comprometimento com a manutenção das instituições de mercado foi garantido e fortalecido graças ao "reformismo fraco" e à inclusão pelo consumo. Essas características se tornaram cruciais no momento de inflexão da crise de 2008 e para a consolidação da estratégia para contornar a crise que foi oficializada pela Lei Federal no 11.977 em $2009^{207}$.

\footnotetext{
${ }^{204}$ Algumas dessas parcerias resultaram nas publicações de Almeida e Santos (2017) e Almeida et al (2017).

Dentre as conclusões das pesquisas, observa-se que o recurso do programa Papel Passado não possui um mecanismo de controle para verificar se a aplicação se dá apenas em casos de interesse social (em alguns casos foi utilizado para regularização de interesse específico). Apontam também que, em vários casos, a irregularidade é produzida pelo próprio estado, como conjuntos habitacionais que não estão aprovados nem registrados. Dentre os tipos de irregularidades observadas, destacam-se cidades inteiras que constam em uma única matrícula, e o fato de muitos casos se darem na transição das áreas rurais para áreas urbanas.

${ }^{205}$ Bonduki (2008).

${ }^{206}$ Rolnik (2015, p.297).

${ }^{207}$ A criação do PMCMV fez parte de uma negociação entre o setor da construção civil - incorporadoras e construtoras - e o Ministério da Fazenda para injeção de recursos públicos no setor (Rolnik, 2015). O contexto da mercantilização da habitação fica claro ao observar que o Programa Minha Casa Minha Vida foi implementado pelos Ministérios da Casa Civil e da Fazenda, com diálogo com os setores imobiliário e da construção civil e, portanto, "é, na origem, um programa econômico" idealizado para que o país sustentasse a economia após a crise de 2008 fortalecendo a indústria da construção civil e o mercado de habitação (Santo Amore, 2015, p.15). Assim, o programa não tramitou pelo Ministério das Cidades, dentro da lógica da Secretaria Nacional da Habitação. Ou seja, o Plano (planejamento) ocorre pelo Ministério das Cidades, que constrói um organograma privilegiando o interesse social, no entanto, na prática, o investimento é feito em paralelo e, portanto, a realização da política também. Segundo Santo Amore (2015, p.15), “O 'Minha Casa Minha Vida' é, antes de tudo, uma 'marca', sob a qual se organiza uma série de subprogramas, modalidades, fundos, linhas de financiamento, tipologias habitacionais, agentes operadores, formas de acesso ao produto "casa própria" - esta sim uma característica que unifica as diferentes experiências".
} 
A estratégia inicial idealizada pelo setor da construção civil consistia na produção de unidades habitacionais dirigida a diferentes extratos de renda - com a maior parte destinada à faixa de renda de quatro a dez salários mínimos - e que contaria com recursos públicos direcionados ao mutuário final, com um fundo de garantia dos empréstimos. A adaptação realizada pelo governo petista foi o aumento no número total de unidades (de duzentas mil para um milhão de unidades) e o aumento do percentual de unidades destinada à faixa de menor renda ${ }^{208}$.

Deste modo, a Lei Federal № 11.977 aprovada em 2009 instituiu as normas para realização da política habitacional no momento de disponibilização de grande aporte de recursos da história para esse fim, mas com objetivos adversos. A Lei regulamentou o Programa Minha Casa Minha Vida (Capítulo I), a revisão do sistema de registros públicos (Capítulo II) e a revisão dos critérios para a regularização fundiária de assentamentos urbanos, inclusive de interesse social (Capítulo III). É fundamental destacar aqui que o grande volume de recursos foi destinado à implantação do Programa MCMV e, por isso, foi o item da Lei que teve maior força em todo o país, deixando a regularização fundiária em um patamar secundário.

Rolnik $^{209}$ contextualiza as recentes políticas habitacionais brasileiras em nível mundial, e mostra que se trata "de um longo processo de desconstrução da habitação como um bem social e sua transmutação em mercadoria e ativo financeiro", como parte de uma transformação da natureza do capitalismo a que ela usa a denominação de "financeirização". Considerando a lógica aplicada ao contexto brasileiro, passa a incluir a população de média e baixa renda nos sistemas de financiamentos habitacionais. Segundo a autora, a ideologia da casa própria teve papel fundamental na consolidação desse modelo 210 .

\footnotetext{
208 Rolnik (2015).

${ }^{209}$ Rolnik (2015, p.27).

${ }^{210}$ A casa própria tem sido ofertada como a principal alternativa à demanda por habitação do extrato de baixa renda da sociedade desde a década de 1930, impulsionada principalmente pela Lei do Inquilinato, mas também pelas soluções apresentadas pelo governo nesse período que trouxeram como opção central a aquisição de terrenos periféricos a preços reduzidos e a serem pagos em prestações, combinada à autoconstrução. Como a Lei do Inquilinato teve como consequência um processo em grande escala de demolição das construções e o decorrente despejo dos inquilinos, a casa própria tornou-se a principal reivindicação, por ser em verdade a única alternativa vista como possível (Bonduki, 1994). Ainda, segundo
} 
Desde o início da implantação do programa, pesquisas destacaram incongruências, principalmente relacionando o déficit do país aos critérios de distribuição de recursos por faixas de renda ${ }^{211}$ e inúmeras críticas quanto à localização periférica dos conjuntos, ausência de equipamentos e infraestrutura, baixa qualidade construtiva, padronização das unidades e porte dos empreendimentos ${ }^{212}$.

Por ter fundamentalmente o papel de dinamizar a economia, as empresas construtoras passaram a ter um papel central no programa ${ }^{213}$. A Caixa Econômica disponibiliza o recurso para as empresas que se tornam as principais promotoras, responsáveis pela escolha dos terrenos, desenvolvimento dos projetos e construção dos conjuntos. O recurso é disponibilizado a partir da aprovação dos projetos pela prefeitura ${ }^{214}$.

Nesse sentido, a empresa - apesar de não ter gasto de incorporação por receber o valor total da Caixa - promove o programa segundo uma lógica de minimização de custos para viabilização econômica desse tipo de empreendimento, conseguida pela escolha de terrenos mais baratos, que permitam a implantação de um grande número de unidades e a padronização da construção - combinada, portanto, à racionalidade industrial $^{215}$.

Uma das mudanças propostas pela Lei Federal no 11.977/2009 é a composição dos agentes que integram o Sistema Financeiro da Habitação. A Lei propõe como substituição do Banco Nacional da Habitação a inclusão dos bancos múltiplos, bancos

\footnotetext{
Bonduki (1994, p.730), a casa própria teve destaque como a melhor solução para o problema pois, tendo em vista a construção de baixo custo, não confrontou os valores salariais e semeou a propriedade privada entre os trabalhadores, "dando melhor estabilidade ao sistema político e econômico". Desse momento em diante a propriedade, ou a casa própria, tem sido vista como a única possibilidade para a questão habitacional, o que criou o cenário mais adequado para implantação do modelo do PMCMV.

${ }^{211}$ Santo Amore (2015).

${ }^{212}$ Sobre as características predominantes dos conjuntos habitacionais produzidos pelo PMCMV ver Cardoso (2013) e Santo Amore, Shimbo e Rufino (2015).

${ }^{213}$ No PAR - Programa de Arrendamento Residencial -, criado pelo governo FHC e utilizado pelo governo Lula com maior aporte de recurso público, "o empreendedor privado [também] era o responsável por toda a operação, da compra do terreno até a construção, passando pela elaboração do projeto (...)" e o financiamento ao mutuário era subsidiado pela Caixa Econômica Federal (Rolnik, 2015, p.289). Desse modo, "para a Caixa, utilizar o modelo do PAR seria muito mais simples e rápido do que criar um novo modelo operacional" (Rolnik, 2015, p.301).

${ }^{214}$ Cardoso e Aragão (2013).

${ }^{215}$ Shimbo (2010); Rufino (2015); Cardoso e Aragão (2013).
} 
comerciais, caixas econômicas, associações de poupança e empréstimo, caixas militares, entidades abertas de previdência complementar, companhias securitizadas de crédito imobiliário e outras incluídas pelo conselho monetário. Apesar da presença dos demais agentes no conteúdo da lei, a Caixa Econômica Federal assumiu papel central na execução do Programa Minha Casa Minha Vida, além de outros programas como o PAC e outras políticas sociais ${ }^{216}$. Essa mesma Lei dá permissão para a livre pactuação entre as partes para a capitalização com juros das entidades do Sistema Financeiro da Habitação.

Com relação ao registro dos imóveis produzidos pelo PMCMV, a Lei prevê a redução das custas e dos emolumentos decorrentes dos atos de abertura de matrícula, registro de incorporação, parcelamento do solo, averbação da construção, instituição de condomínio, averbação da carta de "habite-se" e demais atos referentes à construção de empreendimentos no âmbito do PMCMV em 90\% para unidades até 60 mil reais, $80 \%$ para unidades entre 60 e 80 mil reais e de $75 \%$ para unidades entre 80 mil e 130 mil reais. A revisão do conteúdo da Lei Federal no 11.977/2009 pela Lei Federal no 12.424/2011 reduz apenas os emolumentos dos mesmos procedimentos de registro e averbação anteriores, e ajusta para 75\% para os empreendimentos do FAR e do FDS e em $50 \%$ para os demais empreendimentos do PMCMV ${ }^{217}$.

Dentre as mudanças promovidas pela Lei Federal no 11.977/2009 na política habitacional, altera a Lei que criou o BNH e o SERFHAU, acrescentando as Companhias Securitizadoras às instituições que integram o SFH, e regula a emissão do CRI (certificados de recebíveis imobiliários). Os seguros passam a ser obrigatórios nos empreendimentos de HIS. A lei também altera as regras para uso do FGTS na compra de imóvel de interesse social.

O que se observa, portanto, é o que o texto da Lei responde às novas demandas do mercado financeiro. A Lei Federal no 12.424/2011 aprofunda o conteúdo de alguns

\footnotetext{
${ }^{216}$ Carvalho (2015).

217 Em Londrina, a Caixa Econômica precisou assumir esse custo, pois não foi pago pelas construtoras e ficou sob a responsabilidade dos mutuários que, segundo a entrevista realizada no cartório de registro, nenhum deles chegou a procurar o cartório.
} 
temas da Lei que funcionaram como ajustes no conteúdo após as primeiras experiências de implantação dos programas. A disputa em torno dos custos dos registros dos imóveis demonstra as dificuldades de legalização dos empreendimentos de interesse social que, na ausência da regulação dos descontos, resultou em conjuntos habitacionais sem registro em diversas cidades.

Podemos chamar esse mesmo período de uma "nova fase" para a promoção da regularização fundiária no Brasil, que teve início quando começaram a ser incorporadas, no âmbito do Ministério das Cidades, medidas para viabilizar a regularização fundiária e a urbanização de assentamentos precários.

Até então, o Governo Federal liberava recursos do FNHIS aos municípios que aprovaram o PLHIS. Tanto recursos do FNHIS como do PAC foram utilizados para urbanização de áreas precárias e produção de moradias para famílias realocadas devido às obras. Com relação às áreas a serem regularizadas/urbanizadas, cabia ao município demarcar as áreas como ZEIS para possibilitar a flexibilização da legislação e baratear os custos.

A publicação mais significativa a respeito do tema da Regularização Fundiária pelo Ministério das Cidades nesse período trouxe referências conceituais daquilo que, naquele momento, o Ministério das Cidades entendia e defendia como a "Regularização Fundiária Plena"218. Neste momento, que podemos chamar de primeira fase do Ministério das Cidades, grandes nomes de intelectuais brasileiros ocuparam cadeiras importantes do Ministério. Esta publicação reflete este período em que o Ministério estava alinhado com o discurso da justiça social fortemente defendido por esses intelectuais.

A publicação aconteceu antes da aprovação da Lei Federal no 11.977/2009, e condensou as principais questões sobre a conceituação, os conflitos, os procedimentos da regularização fundiária, esclarecendo-as para a implementação pelos municípios.

\footnotetext{
218 Livro publicado pelo Ministério das Cidades: Regularização fundiária sustentável - conceitos e diretrizes. Raquel Rolnik [et al.], Brasília: Ministério das Cidades, 2007. Disponível em: http://www.urbanismo.mppr.mp.br/arquivos/File/Livro_Regularizacao_Fundiaria_Plena_Referencias_C onceituais.pdf. Acesso em: 10 de maio de 2017.
} 
Algumas dessas questões colocadas não estavam completamente resolvidas, mas o documento indica caminhos para ultrapassar esses obstáculos.

Pelo conteúdo da publicação fica evidente o posicionamento do Ministério das Cidades sobre a regularização fundiária. Primeiramente, diferenciam-se os usos frequentes do termo "Regularização Fundiária" e esclarece o que se entende por legalização e urbanização de favelas, e o que seria a regularização fundiária plena envolvendo estes dois processos, entre outros. Essa discussão é contextualizada evidenciando os processos que culminaram na atual estrutura fundiária e legal que condicionaram a situação e o grau de informalidade nas cidades brasileiras. Para isso, os autores retomam a discussão sobre a Lei de Terras, Código Civil, Constituição Federal e o princípio da "função social da propriedade".

Naquele momento, o Ministério atuava por meio do Programa Papel Passado que, entre 2004 e 2006 destinou R\$ 30 milhões do OGU para ações de regularização. Inclusive, desde 2004, a gratuidade do primeiro registro de títulos do processo de regularização fundiária estava garantida pela Lei Federal № 10.931/2004, com a criação de convênios com os cartórios de registros de imóveis ${ }^{219}$.

Em todo o conteúdo do livro do Ministério, o papel crucial do município nas proposições legais e nas ações de regularização fundiária é ressaltado para que as ações "curativas" da regularização estejam de fato associadas às ações "preventivas" que controlem a ocupação do solo 220 .

No documento também é mantido um vínculo permanente com os instrumentos do Estatuto da Cidade, e os autores procuram demonstrar os avanços, a pertinência e também formas de aplicação dos instrumentos, entretanto sem ignorar aspectos ambíguos e limitantes deles. Os instrumentos que receberam maior ênfase no documento foram as Zonas Especiais de Interesse Social, como a principal estratégia de flexibilizar a legislação para que as obras de infraestrutura/urbanização não precisem seguir as normas vigentes de uso e ocupação (claramente excludentes), o que

${ }^{219}$ Art. 213, § 15. Não são devidos custas ou emolumentos notariais ou de registro decorrentes de regularização fundiária de interesse social a cargo da administração pública.

${ }^{220}$ Rolnik et al. $(2007$, p.9). 
ocasionaria a remoção de muitas famílias. Da mesma forma, enfatizam que a demarcação das ZEIS limitaria a ação do mercado sobre essas áreas e, assim, posteriormente, se beneficiar das obras e provocar transformações nas áreas descaracterizando o interesse social. Outros instrumentos que receberam destaque foram a Concessão do Direito Real de Uso - CDRU 221 - e a Concessão de Uso Especial para Fins de Moradia, para os casos de regularização em áreas públicas.

Os procedimentos administrativos e procedimentais da regularização fundiária são abordados e detalhados, também no que se refere ao trabalho dos cartórios. Além disso, são discutidos os conflitos que podem surgir entre a urbanização de assentamentos precários e a preservação ambiental. É consenso no texto que devem ser observadas as áreas protegidas, porém nos casos de fundos de vale no espaço urbano (que interessa particularmente ao caso de Londrina), defendem a urbanização para prever a destinação adequada do esgoto, e a manutenção das famílias no local, desde que isto não represente risco para elas.

Dialogando com o conteúdo do livro publicado pelo Ministério, a Lei Federal no 11.977/2009 também inclui dois novos instrumentos ao procedimento da regularização fundiária: a demarcação urbanística e a legitimação de posse. A demarcação urbanística consiste no levantamento e registro da situação atual da área ocupada, que substitui o projeto original do loteamento (quando há) e serve de base para a abertura das matrículas; a legitimação de posse é o registro do reconhecimento da posse daquele imóvel por um possuidor como legítima e que, portanto, está apto a receber o título de propriedade nos termos do instrumento da usucapião (em cinco anos). Após cinco anos, o possuidor deve retornar ao cartório (provavelmente isso deverá ser feito pela CohabLD) para realizar a conversão da legitimação de posse em propriedade (por meio da

\footnotetext{
${ }^{221}$ A Concessão do Direito Real de Uso - CDRU foi originalmente regulamentada pelo Decreto-Lei no 271/1967, e está articulada à política habitacional, principalmente pela impossibilidade de usucapir terrenos públicos. Desse modo, a CDRU substitui o título de propriedade quando a regularização fundiária é realizada em terrenos públicos. Para sua aplicação aos programas habitacionais, a Lei Federal no 11.481/2007 trouxe novos aspectos do uso deste instrumento na regulação da regularização fundiária em imóveis da União. Esta lei alterou o Código Civil, incluindo a CDRU nos direitos reais. Assim, a CDRU se equivale à propriedade em termos legais, e pode ser objeto de hipoteca e alienação fiduciária, bem como deve ser registrada em Cartório de Registro de Imóveis.
} 
usucapião). Esses instrumentos têm grande importância, pois com a demarcação urbanística o documento resultante do levantamento da situação da área passa a ter valor jurídico e independe dos extensos e demorados trabalhos de retificação. A legitimação de posse será a garantia do ocupante para aguardar os cinco anos estabelecidos pela usucapião sem risco de ser removido.

Ainda com relação aos novos instrumentos da Lei Federal № 11.977/2009, destacam-se os artigos 47 e 60, que tratam da conversão da Legitimação de Posse em propriedade. Essa conversão é feita por meio do uso do instrumento da usucapião, ou seja, após comprovados os cinco anos de ocupação, nos termos do artigo 183 da Constituição Federal. Ainda, o artigo 59 garante que a Legitimação de Posse constitui direito em favor do detentor da posse direta para fins de moradia.

Os artigos 49, 51, 52, 53 e 54, apesar de tratarem de diretrizes projetuais - de forma genérica - dão autonomia ao município para traçar suas próprias diretrizes. Porém, a regularização não fica condicionada a transformações significativas no assentamento. A mesma reflexão se aplica à demarcação urbanística tratada no artigo 56, que define os aspectos a serem levantados para viabilizar o processo de regularização, mas não exige as soluções para estes aspectos levantados. No artigo 58, fica claro que após o ato da demarcação urbanística, que viabiliza a subdivisão dos lotes, é dada a legitimação de posse aos ocupantes. Sobre esse ponto, destaca-se ainda o artigo 68 que trata da gratuidade dos registros.

Um dos aspectos da revisão da Lei de Registros Públicos pela Lei Federal no 11.977/2009 é quanto ao procedimento dos registros da legitimação de posse e a averbação do auto de demarcação urbanística ${ }^{222}$. A mudança também institui a gratuidade de todas as custas e emolumentos do registro público para a regularização fundiária de interesse social. Este fator foi fundamental, pois como visto em entrevista na Cohab-LD e em diversas publicações ${ }^{223}$, os custos dos registros constituem um dos principais obstáculos para regularização fundiária de interesse social.

\footnotetext{
222 Outra mudança no sistema de registro promovida pela Lei Federal no 11.977/2009 é a criação, no Capítulo II, do sistema de registro digital, que será tratado com profundidade no próximo capítulo.

${ }^{223}$ Como discutido em Fernandes (2001) e Rolnik et al (2007).
} 


\section{As alterações da Lei Federal no11.977/2009 e a revogação do Capítulo III}

Quando iniciei a pesquisa, a Lei Federal № 11.977/2009 já havia sofrido alterações que aparentemente detalhavam e aprofundavam seu conteúdo da lei. Em 2017, após a reviravolta política de $2016^{224}$, o Capítulo III que regulamentava o programa de regularização fundiária foi revogado pela MP nํ 759/2016 (que deu origem à Lei Federal no 13.465/2017), alvo de muitas polêmicas. Tendo em vista as mudanças da Lei Federal no 11.977/2009, busco compreender o sentido dessas alterações, já com o olhar das práticas conhecidas nas incursões na Cohab-LD e discutidas nos eventos sobre os temas desta lei.

As primeiras mudanças no texto da Lei foram promovidas pela MP no 514/2010, já no seu Art. 10 em que são definidas as finalidades do PMCMV referentes à produção e aquisição de novas unidades habitacionais, requalificação de imóveis urbanos e produção ou reforma de habitações rurais, para famílias com renda mensal de até dez salários mínimos. A nova redação introduz as definições de família, imóvel novo, oferta pública de recursos; requalificação de imóveis urbanos; agricultores familiares; e trabalhadores rurais.

No Art 2으 insere um novo arranjo aos programas e fundos que hoje compõem o PMCMV, passando o Programa Nacional de Habitação Urbana - PNHU - a incorporar as transferências de recursos ao FAR (Fundo de Arrendamento Residencial) e ao FDS (Fundo de Desenvolvimento Social), a concessão de subvenção econômica ao beneficiário pessoa física no ato da contratação de financiamento habitacional; e a realização de oferta pública de recursos, destinados à subvenção econômica ao beneficiário pessoa física, de operações em municípios com população limitada a cinquenta mil habitantes, mantido ainda o Programa Nacional de Habitação Rural PNHR.

\footnotetext{
${ }^{224}$ Em 2016 o PT deixa a presidência da República em meio à uma crise política provocada pela oposição que resultou no processo de impeachment da Presidenta Dilma Rousseff. Logo após o impeachment, uma série de alterações na legislação foram promovidas, incluindo a revogação do capítulo III da Lei Federal no $11.977 / 2009$.
} 
As mudanças no Art. 3으 são referentes aos requisitos para indicação dos beneficiários do PMCMV. Remete ao Poder Executivo, no § 3ㅇ do Art. 3ำ, a competência para fixar os parâmetros de priorização e enquadramento dos beneficiários do PMCMV, os limites de renda familiar aplicáveis às modalidades operacionais que integram o PMCMV, observado o teto legal de dez salários mínimos e a periodicidade de atualização desses limites. Neste mesmo artigo, também possibilita aos entes federados a competência para introduzir "critérios locais de seleção de beneficiários", desde que estes sejam previamente deliberados em conselhos locais de habitação 225 . Também aponta as competências para a execução do trabalho técnico-social pós-ocupação dos empreendimentos do programa.

A MP também proíbe (altera o $\S 10$ dos artigos. 6ㅇ e 13) a transferência das subvenções econômicas concedidas nos programas PNHU e PNHR por meio de subrogações, como forma de garantir que o benefício seja concedido apenas uma vez por pessoa e por imóvel.

No Art. 18 são elevados os valores a serem transferidos pela União para o Fundo de Arrendamento Residencial - FAR -, de R\$ 14.000.000.000,00 (quatorze bilhões de reais) para $\mathrm{R} \$ 16.500 .000 .000,00$ (dezesseis bilhões e quinhentos milhões de reais) ampliando, assim, os recursos públicos destinados à contratação das empresas para incorporação dos conjuntos habitacionais. Isso não quer dizer, necessariamente, que aumenta o número de conjuntos construídos, tendo em vista que muitos recursos foram gastos em conjuntos que não foram concluídos ou em aumentos dos pagamentos para obras já iniciadas.

O Art. 2ํda Medida Provisória acresce artigos à Lei Federal no 11.977/2009. O Art. 5--A estabelece os critérios técnicos de elaboração dos projetos do PNHU; o Art. 6ㅇA prevê unidades destinadas à atividade comercial que ajudarão nos custos condominiais, mas também proíbe a venda desses imóveis para garantir que a renda seja sempre destinada ao condomínio. Essa é uma medida importante visto que os empreendimentos são monofuncionais e, por isso, tende a aparecer o comércio

\footnotetext{
${ }^{225}$ Esta alteração tem particular importância para a análise da implantação do PMCMV em Londrina.
} 
informal para atender à demanda dos bairros. Outro problema apontado por algumas pesquisas é referente ao custo condominial que gera impacto na renda das famílias. No Art. 60-A, a Medida Provisória estabelece dispensa da participação financeira dos beneficiários nas operações que sejam vinculadas a intervenções de "urbanização de assentamentos precários, saneamento integrado, manejo de águas pluviais e prevenção de deslizamento de encostas, que demandem o reassentamento, remanejamento ou substituição de unidades habitacionais". O Art. 71-A instrumentaliza o Poder Público para a urbanização de assentamentos irregulares de baixa renda situadas em áreas já transferidas à população moradora, por meio dos instrumentos da concessão de uso especial para fins de moradia e concessão de direito real de uso. O Art. 82-B dispõe sobre a criação da segunda etapa do PMCMV, que tem como proposta "promover a produção, aquisição, requalificação e reforma de dois milhões de unidades habitacionais, a partir da data de publicação da Medida Provisória até dezembro de 2014, garantindo ainda que as diretrizes permanentes para a continuidade do programa sejam definidas no Plano Nacional de Habitação, a ser apresentado pelo Poder Executivo".

A MP também detalha os procedimentos de regularização fundiária de assentamentos urbanos, instituídos pela Lei Federal no 11.977/2009 com a intenção de facilitar os mecanismos de individualização de imóveis públicos e seu respectivo registro nos cartórios. O objetivo é possibilitar a regularização de ocupações nesses imóveis e viabilizar a urbanização utilizando recursos do PMCMV.

Também em relação às alterações que a MP promove no âmbito dos registros dos imóveis (alterando a Lei Federal no 6.015, de 1973), são alterados os Artigos 205, 213, 221 e 235, que tratam respectivamente: da "ampliação de prazo para atendimento, pelos promotores de regularização fundiária de interesse social, de exigências legais eventualmente indicadas pelo oficial de registro de imóveis; de novas hipóteses de registro independentemente de retificação, da retirada da restrição ao registro de termos e contratos administrativos, e da unificação de matrículas de imóveis objeto de imissão na posse, permitindo que a regularização fundiária se efetive antes da finalização do processo judicial de desapropriação". Desta forma, como os processos de 
desapropriação são lentos, a posse aos ocupantes fica judicialmente garantida até a conclusão do processo.

A Lei Federal o 12.350/2010 modifica o texto sobre os beneficiários do Art.3으, que passa a considerar como critério de seleção das famílias o tempo de residência ou de trabalho do beneficiário no Município e a adequação ambiental e urbanística dos projetos apresentados. Este critério relativo ao tempo de trabalho no município atende àquelas famílias que não residem no município e, por isso, não cumprem o critério de tempo de residência na cidade do empreendimento, mas que se deslocam de outras cidades diariamente a trabalho.

Nas alterações decorrentes da Lei Federal no 12.424/2011, novamente são revistos os conceitos; os critérios de prioridades para os beneficiários do PMCMV, quando são colocados os moradores de áreas de risco, insalubres e desabrigados, mulheres chefes de família e a reserva do porcentual de unidades aos portadores de necessidades especiais; os critérios de subvenção econômica pelo BNDES; critérios de qualidade para os empreendimentos do PNHU; redução de emolumentos para registros dos empreendimentos do PMCMV; a inclusão da Assistência Técnica para Habitação de Interesse Social (ATHIS) na previsão de custos do PNHU; definição de conceitos da Regularização Fundiária; e o estabelecimento de regras para os novos instrumentos da Demarcação Urbanística e da Legitimação de Posse.

Outras alterações promovidas pela Lei Federal no 12.424/2011 também indicam que foram necessárias adequações nos procedimentos da realização dos programas. Um exemplo é a inclusão no Código Civil (Art. 1.240-A) do instrumento da usucapião familiar, que garante o domínio pleno do imóvel à família que resida de forma ininterrupta por dois anos, sem oposição e por posse direta, um imóvel urbano de até $250 \mathrm{~m}^{2}$ que seja de propriedade dividida ou exclusiva do ex-cônjuge que abandonou o lar, desde que não seja proprietário de outro imóvel.

As alterações na Lei de Registros Públicos (Lei Federal no 6.015/1973) dizem respeito à Imissão Provisória da Posse, para solucionar a regularização fundiária em áreas que estão em processo de desapropriação por utilidade pública; ao registro e 
extinção da Legitimação de Posse e à conversão da Legitimação de Posse em propriedade; detalhamento sobre retificação, documentação e registro da Regularização Fundiária; definições quanto à circunscrição imobiliária das áreas ocupadas, das ações do registrador; e da gratuidade do registro e da conversão da Legitimação de Posse.

A Lei Federal no 6.766/1979 é alterada para tratar do registro das áreas públicas dos loteamentos implantados, mas não registrados, e a Lei Federal no 4.591/1964 é ajustada para incluir os casos de Imissão de Posse. O Código Civil também é alterado para dar segurança à posse da família no caso de cônjuge que abandona o lar. A Lei Federal no 12.424/2011 também revoga os dispositivos que tratam da cobertura securitária nos empreendimentos de interesse social.

O conteúdo das alterações indica que foram necessárias adequações no texto para melhor enquadrar, ajustar os prazos, ampliar cobertura dos recursos, para garantir a operacionalização dos procedimentos previstos inicialmente. São complementos e aprofundamentos do texto original. Isso também pode ser observado nas alterações promovidas pela Lei Federal no 12.424/2011 e na complementação de conteúdo que ela traz à matéria da Lei Federal no 11.977/2009.

Considerando o conteúdo que trata dos procedimentos da regularização fundiária, o que está por trás de todas essas alterações e instrumentos é a inclusão da exceção no escopo do direito. Com relação aos imóveis públicos, a regularização de ocupações irregulares demanda reflexão sobre o caráter de privatização que este procedimento pode assumir, por isso a importância de instrumentos com a Concessão do Direito Real de Uso para fins de Moradia. Entretanto, as brechas criadas pela discussão sobre a regularização em imóveis públicos abriram caminho para que interesses de alienação e privatização de áreas públicas ganhasse espaço. Por isso, estas questões são particularmente importantes na análise da revogação do Capítulo III da Lei Federal no 11.977 de 2009.

Ao mesmo tempo, a regularização fundiária promovida em áreas particulares enfrentou resistência do pensamento proprietário que vigora no direito brasileiro. Isso 
é decorrente da predominância do direito civil sobre o direito público na tradição clássica da formação dos cursos de direito. Apesar da Constituição Federal de 1988 ser analítica e seu conteúdo trazer essa dimensão do direito público para um patamar mais elevado, a disposição quanto aos direitos fundamentais e o conceito de função social da propriedade ainda não foram incorporados à visão do intérprete ${ }^{226}$

Essas questões ganham complexidade quando um processo de regularização ocorre em uma área que tem parte sob domínio público e parte de domínio privado. Antes da abordagem da Lei Federal no 11.977/2009 isso não seria possível e para alguns intérpretes ainda é difícil conceber essa regularização em um processo único, por meio do instrumento de demarcação urbanística sem a necessidade de desapropriação ${ }^{227}$. Esta é uma das questões de maior conflito de entendimento, pois mesmo com a existência do instrumento da usucapião, ele era visto apenas como um mecanismo de regularização individual neste contexto jurídico clássico. A aplicação da Demarcação Urbanística e da Legitimação de Posse, permite que a regularização fundiária seja realizada sobre o assentamento em um único processo, independente das diferenças entre tempo de residência e domínio original dos terrenos. Isso, sem dúvida, reduz o tempo e a burocracia em relação à abertura de processos individuais para cada unidade habitacional.

Esse é um dos mecanismos que possibilita a regularização fundiária em massa, uma das novidades da Lei Federal no 11.977/2009 que será aprofundada mais adiante. Outra novidade que visa agilizar o procedimento da regularização fundiária previsto no conteúdo da Lei Federal no 11.977/2009 é referente à criação da usucapião administrativa ou extrajudicial ${ }^{228}$, ou seja, o uso da usucapião com dispensa de

\footnotetext{
${ }^{226}$ Informações contidas na entrevista concedida pela advogada do 2ํ Cartório de Registro de Imóveis de Londrina. Em defesa da lei de regularização fundiária, advogados também reforçaram essa crítica à formação clássica dos intérpretes nos eventos do campo jurídico sobre o tema da regularização de interesse social. Esta crítica também é mencionada no Livro sobre Regularização Fundiária do Ministério das Cidades (Rolnik et al., 2007).

${ }^{227}$ Informações contidas na entrevista concedida pela advogada do 2o Cartório de Registro de Imóveis de Londrina.

228 Os institutos da usucapião existentes anteriormente à criação da Usucapião Administrativa são: a usucapião extraordinária prevista no Art. 1.238 do Código Civil; a usucapião ordinária prevista no Art. 1.242 do Código Civil; a usucapião especial rural prevista no Art. 191 da Constituição Federal e no Art. 1.239 do Código Civil; a usucapião urbana prevista no Art. 183 da Constituição Federal e no Art. 1.240 do
} 
intervenção judicial. Nesse caso, o pedido de usucapião pode ser feito no Cartório de Registro de Imóveis, dispensando a ação judicial que tende a ser muito demorada. Nesse sentido, portanto, a posse passa a ser consagrada com maior ênfase no direito brasileiro, que historicamente tem consagrado o direito de propriedade em detrimento da posse.

A polêmica revogação do Capítulo III ${ }^{229}$ envolveu temáticas mais amplas do que a regularização fundiária de interesse social. No entanto, compreender os novos termos da Lei como um todo, nos permite prospectar aspectos desta disputa em torno da legalização da posse informal de terras no Brasil. O anúncio das mudanças ocorreu primeiramente no texto da Medida Provisória no 759/2016 e, posteriormente e com algumas mudanças, foi convertida em Lei Federal no 13.465/2017.

Diversos aspectos da tramitação da medida provisória e da Lei Federal no 13.465/2017 evidenciam seu caráter de exceção. Essa lei altera mais de 20 leis e decretos, e tramitou mais rápido do que o normal. Ainda, a medida provisória revogou dispositivos de leis complementares sem respeitar a hierarquia entre os instrumentos da legislação.

Segundo a Dr.a Daniela Campos Libória ${ }^{230}$, presidente do Instituto de Direito Urbanístico, a elaboração da MP com o argumento de que era relevante e urgente não corresponde, e na verdade trata-se de um sistema que vem sendo discutido há décadas sobre regularização da situação dos condomínios e da situação das terras da União na Amazônia. Na visão dela, o texto da MP fragmenta o tema da política habitacional e gera distorções.

A criação de uma MP tem como foco sempre um tema, pois é a urgência de alguma situação específica que precisa ser ajustada. Porém a inclusão da Regularização Fundiária Urbana, da Regularização Fundiária Agrária e Doação de Terras da União não corresponde a esta situação já que, em tese, não há convergência entre esses temas.

código civil; a usucapião coletiva prevista no Art. 10 do Estatuto da Cidade; e a usucapião especial que foi incluída no Código Civil (Art. 1.240-A) pela Lei Federal no 12.242/2011.

${ }^{229}$ Diversas entidades como o Instituto de Arquitetos do Brasil - IAB - e Ordem dos Advogados do Brasil - OAB - se manifestaram contrárias à aprovação da Lei Federal № 13.465 de 2017, argumentando inconstitucionalidade da Lei.

230 Presidente do Instituto Brasileiro de Direito Urbanístico (IBDU) 2013-2017. 
É evidente no conteúdo da Lei a perda das referências conceituais existentes na Lei Federal no 11.977/2009, o foco são os instrumentos de titulação e da segurança jurídica da posse e a regularização é totalmente desvinculada do planejamento urbano.

Em defesa das mudanças propostas no texto da Lei que visa regular a regularização fundiária no contexto brasileiro, o representante do Ministério das Cidades $^{231}$ argumentou que as mudanças propostas visaram solucionar problemas e obstáculos encontrados durante as tentativas de aplicação da Lei Federal $\mathrm{n}$ 은 11.977/2009. Segundo Sílvio Figueiredo, dentre as negociações para aprovar a Lei Federal no 13.465/2017, esteve a volta das Zonas Especiais de Interesse Social e da Legitimação de Posse para o texto (pois haviam desaparecido no conteúdo da Medida Provisória no 759/2016).

No momento da implementação da Medida Provisória № 759/2016, os argumentos colocados pelo Ministério das Cidades tratavam de uma série de questões pontuais sobre a realização da regularização fundiária como a necessidade de implantação de um sistema georreferenciado e de disponibilizar as ferramentas para os municípios para que eles consigam montar um plano efetivo de regularização; o interesse em gerir o programa por meio de um site que possibilitasse o preenchimento de dados, concorrência de licitações e orçamentos; a intenção de promover a

\footnotetext{
${ }^{231}$ Me refiro à fala do arquiteto Sílvio Figueiredo no I Seminário de Habitação Alto Tietê - 2016 pelo Condemat - Consórcio de Desenvolvimento dos Municípios do Alto Tietê em Mogi das Cruzes (SP) em 07/06/2016. Sílvio Figueiredo era, na época, diretor da Secretaria Nacional de Programas Urbanos, departamento de assuntos fundiários urbanos, cargo anteriormente ocupado por Raquel Rolnik antes das mudanças mencionadas. As competências do Departamento de Assuntos Fundiários são: "I-conceber, estabelecer e implementar diretrizes, normas, políticas, procedimentos e ações relacionados à regularização fundiária urbana; II - elaborar e implementar programas, estabelecer critérios para a seleção, priorização e eleição dos investimentos em Estados e Municípios, voltados para a regularização fundiária urbana, em consonância com as demais Secretarias Nacionais; III - propor a formulação de programas de apoio e capacitação técnica para as ações de desenvolvimento institucional voltadas à regularização fundiária urbana; IV - executar e acompanhar programas, políticas, procedimentos e ações relacionados à regularização fundiária; $\mathrm{V}$ - avaliar os resultados alcançados pelos programas, políticas, procedimentos e ações de sua competência; $\mathrm{VI}$ - integrar as políticas relacionadas à regularização fundiária urbana, com as demais políticas públicas do Governo federal voltadas para o desenvolvimento urbano, em consonância com as demais Secretarias Nacionais do Ministério das Cidades; VII - subsidiar e propor: a) o aperfeiçoamento da legislação e de mecanismos institucionais diferenciados; b) o desenvolvimento de estudos e pesquisas na área de regularização fundiária urbana; VIII - subsidiar a elaboração de publicações técnicas e de material de divulgação relacionados à regularização fundiária urbana." (Decreto no 8.927 de 2016).
} 
capacitação técnica dos municípios e auxiliar municípios muito pequenos disponibilizando a estrutura técnica e jurídica do próprio ministério; a criação de convênios para liberação de recursos, inclusive para infraestrutura por meio do envolvimento com as secretarias de habitação e saneamento; entre outras. Entretanto, nenhuma dessas práticas estava impossibilitada pelo conteúdo da lei anterior, e poderiam ser previstas sem a necessidade de revogação do texto original.

Além disso, uma das principais questões que aparecem já no texto da MP no 759 é a aplicação de novos conceitos relacionados à regularização fundiária. Foram criadas siglas e feita uma diferenciação entre os conceitos de Regularização Fundiária de Interesse Social - Reurb-S - e Regularização Fundiária de Interesse Específico - ReurbE. Essa diferenciação já existia, mas foram acrescidas informações sobre a regularização de interesse específico, principalmente relacionadas aos loteamentos fechados e a empreendimentos comerciais.

Outro fator importante do novo texto é referente à abordagem sobre a Amazônia Legal. Apesar de existir uma lei que trata especificamente desse tema, o argumento em defesa dessa abordagem foi que como o conceito de regularização fundiária ficou focado em área urbana, isso impedia a regularização dentro da Amazônia Legal| $^{232}$ - onde não é possível classificar como área urbana - e algumas regiões do centro-oeste. Ainda que situadas em área rural, os usos e as características são de área urbana. Entretanto, essa visão ignora a existência da Lei Municipal do Perímetro Urbano, o que claramente beneficia condomínios fechados localizados fora do perímetro urbano e que, por isso, enfrentam problemas na obtenção do "habite-se". Cabe destacar que os conflitos na definição e caracterização de áreas urbanas e rurais não são particulares da Lei Federal no 13.465/2017, visto que o Estatuto da Terra (Lei Federal no 4.504 de 1964)

\footnotetext{
${ }^{232}$ Ainda que esta questão sobre a regularização de núcleos na Amazônia Legal ocorra de fato, conforme explanação de Fisher e Siqueira (2017), o instrumento da Lei Federal “Terra Legal” no 11.952/2009 aborda tais peculiaridades fundiárias e propõe normas para a regularização fundiária de núcleos situados em terras da União no âmbito da Amazônia Legal. Os principais problemas nesta região se dão pelo fato de existirem mais títulos do que áreas, devido às grilagens de terras. Além disso, os municípios não se mobilizam para regularizar por serem terras de domínio federal (Fisher e Siqueira, 2017). Ainda, nesta região, municípios inteiros encontram-se em áreas públicas ou em áreas griladas, agravando a situação da informalidade das ocupações. Porém, Fisher e Siqueira (2017) argumentam que a Lei Federal no 11.952/2009 não cobra projeto urbanístico, mas que trata apenas da titulação dos imóveis.
} 
define a natureza do imóvel pelas suas características, pela sua atividade, e não pela localização (dentro ou fora do perímetro urbano), como sugere a Lei de Perímetro Urbano Municipal ${ }^{233}$. Isso mostra que a própria legislação não possui um único critério de interpretação.

Apesar de não ficar claro se esses núcleos localizados em áreas rurais, após a regularização, passarão a pagar o imposto urbano (IPTU), os argumentos dos favoráveis à MP no 759 e à Lei Federal no 13.465/2017, evidenciam os benefícios do aumento da arrecadação municipal pelo IPTU.

No lugar da expressão "assentamentos irregulares" que aparecia na Lei Federal no 11.977/2009, passa-se a usar "assentamentos informais" para remeter à ausência de planejamento. O Núcleo Urbano Informal não se refere mais necessariamente à habitação e, por isso, passa a ser diferenciado entre interesse social e interesse específico. No texto original, os núcleos informais deveriam estar em áreas demarcadas como ZEIS e esperar os cinco anos - de acordo com os termos da usucapião - para viabilizar a regularização. No novo texto foi proposto que cabe ao município definir se a regularização é de interesse social (com base nas condições socioeconômicas das famílias) e a realiza por meio de Ato Executivo Municipal.

Um ponto em disputa na revisão da lei é a gratuidade referente à isenção de custas e emolumentos dos atos registrais que estava prevista na Lei Federal no 11.977/2009. Os cartórios argumentam que essa garantia de gratuidade ocasionou vários problemas para eles. Segundo dados usados nas falas em defesa da cobrança das custas e emolumentos, mais de $50 \%$ dos cartórios têm faturamento inferior ao custo de sobrevivência, o que levou ao gargalo da regularização (pois esse não é um procedimento barato). Dessa forma, a Lei Federal no 13.465/2017 propõe a utilização de recursos do Fundo Nacional da Habitação - FNHIS - para custear os atos registrais, garantindo a gratuidade para o usuário, sem que o cartório arque com isso.

233 O Art. 4ํ, inciso I, da Lei Federal no 4.504/1964 define imóvel rural como “o prédio rústico, de área contínua qualquer que seja a sua localização que se destina à exploração extrativa agrícola, pecuária ou agro-industrial, quer através de planos públicos de valorização, quer através de iniciativa privada". 
No texto final, para áreas públicas ou privadas, de interesse social ou não, a prefeitura realiza os levantamentos e depois o edital. Se não houver impugnação, a prefeitura encaminha o projeto de regularização para o cartório com o nome e CPF de cada ocupante. O cartório gera a matrícula originária, sem a necessidade da matrícula mãe, e depois para cada ocupante.

Dentre as outras novidades ${ }^{234}$, a Lei Federal no 13.465/2017 também tornou possível a legitimação de posse para áreas com mais de $250 \mathrm{~m}^{2}$ e não necessariamente para fins de habitação, bem como muda o critério do tempo da ocupação, facilitando para ocupações que não estão consolidadas e para usos e atividades que não são referentes à habitação de interesse social. Isso ocorre devido à supressão do indicador da consolidação da área que estava presente na Lei Federal no 11.977/2009.

Com relação às ocupações em áreas de risco, a Lei exige a comprovação das formas de controle do risco, se não for possível, é necessário realocar. Para isso, é indispensável o estudo técnico ambiental para regularização de áreas inseridas em APP e mananciais. Assim, poderão ser regularizadas por ente público com base no estudo técnico ${ }^{235}$. Essa previsão de supressão da APP já constava na Lei Federal no 11.977/2009, mas foram acrescidas as exigências sobre o projeto de regularização que ocorrerá em APP. Apesar de aparentemente sugerir maior segurança, a exigência do projeto mostra que a questão é viabilizar para quem tem recursos para solucionar os problemas decorrentes da ocupação que levam ao risco. Nesse caso, devido à ausência de previsão orçamentária para esse fim, o peso da preservação ambiental acaba recaindo com pesos diferentes para os diferentes extratos sociais. Quem aprova esses projetos é o próprio município (se for capacitado, ou seja, se tiver profissionais com capacidade técnica). Tudo isso independe do licenciamento ambiental, que não é mais exigido para esses casos; é aplicável apenas para projeto em novas áreas.

\footnotetext{
${ }^{234}$ Outra novidade é o instrumento do Direito Real de Laje, que possibilita a regularização fundiária para os casos de casas sobrepostas, considerando a propriedade do espaço aéreo. Como solução para regularização de loteamentos de acesso controlado, o controle de acesso deve ser regulamentado por ato do poder público municipal.

${ }^{235}$ A Lei altera o artigo 64 do Código Florestal (Lei Federal no 12.651/2012).
} 
Com relação ao cronograma das obras urbanísticas e ambientais, enquanto na Lei Federal no 11.977/2009 era possível um cronograma apenas documental, agora será definido pelos técnicos e garantido mediante um Termo de Compromisso, com cronograma de obras contendo abastecimento de água potável, rede de esgoto ou fossa, energia elétrica, drenagem, ou outro tipo de infraestrutura que a prefeitura possa achar necessário. Porém, não se fala mais em infraestrutura "básica" (contida na Lei Federal de Parcelamento do Solo, Lei Federal no 6.766/1979), que no novo texto é abordada como infraestrutura "essencial", sem aprofundamento sobre o significado do termo "essencial".

Outra polêmica da Lei é referente à alienação de imóvel público, quando se trata de área consolidada e de condição irreversível. A Lei dispensa a desafetação, ou seja, dispensa os procedimentos previstos na Lei Federal no 8.666/1993. Como não são estabelecidos os critérios de definição sobre a consolidação considerada irreversível, nos questionamentos sobre a constitucionalidade da Lei Federal no 13.465/2017 argumenta-se que existem outros instrumentos que viabilizam a regularização fundiária em áreas públicas, como a CDRU, por exemplo, e que a alienação como está prevista configura privatização. O mesmo questionamento se aplica aos termos de alienação de terras da União.

Um dos instrumentos mais controversos trazidos por essa Lei é a Legitimação Fundiária, que possibilita a aquisição de áreas públicas ou privadas, rurais ou urbanas. Trata-se da transferência da área aos ocupantes, sem respeitar os termos constitucionais da usucapião tanto em relação aos prazos, mas principalmente por permitir uma espécie de usucapião em terras públicas - que é proibida pelo código civil -, o que configura a privatização dessas áreas. Segundo a advogada entrevistada, isso viola a supremacia do interesse público sobre o particular.

Outro documento criado por essa Lei é a Certidão de Regularização Fundiária CRF - que corresponde ao documento que oficializa a regularização do assentamento, inclusive do projeto de regularização correspondente. O registro da $\mathrm{CRF}$, que dará origem à "matrícula-mãe" da área, cancela o registro do Cadastro Ambiental Rural CAR. 
Ainda quanto às mudanças da Lei Federal no 13.465/2017, os instrumentos da Demarcação Urbanística e as ZEIS haviam sido retirados do texto da Lei na MP, mas retornaram em negociações com a bancada do PT. A justificativa do representante do Ministério é que a demarcação urbanística não é mais obrigatória por ser apenas parte do desenvolvimento e aprovação do projeto que serve apenas para levar no cartório e fazer a averbação. Do mesmo modo, o processo é independente de a área estar situada em ZEIS, por isso a intenção de retirar do texto. Aparentemente, há intenção de descaracterizar ou invisibilizar o conflito fundiário desse tema, representado principalmente pela criação do instrumento das ZEIS.

Apesar da volta do instrumento da Legitimação de Posse para o conteúdo da lei, o Art. 24 sugere que a Legitimação pode ser questionada, o que contradiz o próprio conceito do instrumento que visa garantir a segurança jurídica da posse aos ocupantes.

Também estão previstas as Câmaras de prevenção e resolução de conflitos. Se realmente o município decidir encarar o conflito pela terra, a composição dessas câmaras será um importante espaço de disputa. Entretanto, se o próprio município for interessado na posse do terreno, ele atuará tanto como interessado como mediador, gerando um conflito claro de interesses que remete ao questionamento do valor "justo" que deve ser estabelecido para o imóvel.

Uma das principais polêmicas em torno da aprovação da Lei Federal $n$ 으 13.465/2017 é o fato dela abordar a regularização fundiária em área rural, sendo que existe legislação específica para esse tema. Nesse sentido, argumento que apesar de aparentemente não haver convergência de temas, a titulação em massa parece ser a linha que amarra todos os temas da nova lei de regularização fundiária. De forma contraditória (como é o próprio estado de Exceção), essa legalização em massa pressupõe ao mesmo tempo a destituição do caráter legal de documentos préexistentes para viabilizar essa nova configuração ${ }^{236}$.

${ }^{236}$ A Lei prevê que, para que não haja óbice para o registrador, se a regularização abranger mais de um imóvel e o projeto não estiver igual ao da matrícula, o registrador abre uma nova matrícula e está dispensado de fazer a correção, unificar e fazer nova descrição, já que estes procedimentos resultariam em custos. Assim, as matrículas anteriores perdem automaticamente seu valor legal, o que mostra a volatilidade desses documentos. Essa contradição não é nova, considerando que no Brasil convergem um 


\section{O Programa Minha Casa Minha Vida em Londrina e a remoção de favelas}

Como comentado, a desarticulação com a política urbana tem sido uma das críticas apontadas ao PMCMV237. Segundo Rolnik (2015, p.243), com base nos dados da Rede de Pesquisa Cidade e Moradia, "todos os municípios pesquisados abandonaram suas políticas para 'rodar' o programa". Isso representa um retrocesso frente ao período que precede a criação do MCMV, em que as políticas habitacionais vinham sendo construídas com base nos princípios da função social da propriedade - ou, ao menos, caminhando para tal - e na tentativa de implantação dos instrumentos do Estatuto da Cidade $^{238}$, conforme os objetivos iniciais do Ministério das Cidades.

O que temos, portanto, de apontamentos sobre o resultado da implantação do PMCMV no país representa a inclusão da população de média e baixa renda no circuito de capitais por meio do endividamento com a provisão de casas e apartamentos de baixa qualidade construtiva e espacial, localizados em áreas periféricas com infraestrutura e equipamentos precários que não garantem cidade e moradia digna, mas garantiram a lucratividade e a sustentação do setor da construção civil. Foi observado em diversas cidades que o programa serviu para justificar a remoção de ocupações irregulares e favelas e, em alguns casos, para liberar áreas para grandes obras ${ }^{239}$.

\footnotetext{
sistema altamente burocrático de registro de imóveis ao mesmo tempo em que a grilagem de terras e a produção de títulos "frios" ou "documentos de gaveta" seguem como práticas frequentes na ocupação dolo urbano e rural.

${ }^{237}$ Rolnik (2015); Cardoso e Aragão (2013); Santo Amore (2013); Santo Amore (2015).

${ }^{238}$ Santo Amore (2015).

239 Rufino (2015). No Rio de Janeiro, o trabalho de Magalhães (2013) mostra que a implantação dos Conjuntos do PMCMV legitimou a remoção de um grande número de famílias de favelas localizadas em regiões que passaram pelo processo de valorização do solo urbano devido às intervenções decorrentes dos megaeventos.
} 


\section{O PMCMV nas margens da legalidade}

Para compreender o andamento da política habitacional que antecedeu o início do Programa de Regularização Fundiária, apresento alguns dados e análise sobre a implantação do Programa Minha Casa Minha Vida em Londrina. Estas informações revelam algumas características referentes à localização dos empreendimentos; datas dos contratos, valores e quantitativos gerais de cada empreendimento; dados sobre as remoções, como a definição das áreas de origem e a quantidade de famílias. Detalho dois casos (Residencial Vista Bela e Residencial Cristal I e II) para possibilitar uma análise mais profunda sobre a execução do programa no que se refere à gestão das ocupações irregulares.

O convênio firmado para realização do Programa Minha Casa Minha Vida em Londrina foi assinado durante a gestão do prefeito Barbosa Neto (PDT). Como nas demais cidades, o esboço da política habitacional que começava a ser desenhado pela elaboração do Plano de ZEIS foi interrompido para dar lugar à implantação do PMCMV. Como mostrarei adiante, o processo de implantação do programa foi permeado por práticas que extrapolam os limites da legalidade. Foram previstos empreendimentos em diferentes regiões da cidade de Londrina, todos eles nas franjas urbanas. O Residencial Vista Bela merece destaque pois concentrou em um mesmo terreno dez contratos (com três construtoras diferentes), totalizando 2.812 unidades $^{240}$.

O objetivo deste tópico é compreender a mecânica do procedimento da remoção das famílias residentes em ocupações irregulares realizado pela Cohab-LD na destinação das unidades produzidas pelo PMCMV. De acordo com as informações coletadas e do que considero relevante para alinhavar a argumentação da tese, utilizo informações de procedimentos sobre diferentes Conjuntos Habitacionais do PMCMV, a saber: Residencial Vista Bela I ao X, Residencial Cristal I e II, e Residencial Flores do Campo ${ }^{241}$.

\footnotetext{
240 Dado obtido no site da Caixa Econômica Federal.

${ }^{241} \mathrm{O}$ caso do Residencial Flores do Campo corresponde a um conjunto que não teve sua construção finalizada e foi ocupado irregularmente por cerca de 400 famílias em 2016. Até hoje [2019], foram suspensas três reintegrações de posse e está em trâmite um acordo de realocação das famílias para outras
} 
Também interessa compreender os critérios que embasaram as decisões. Para isso, utilizo dados quantitativos obtidos em pesquisa no site da Caixa Econômica Federal, dados quantitativos e qualitativos obtidos na pesquisa documental realizada no Setor Social da Cohab-LD e entrevistas com funcionários da Cohab-LD (inclusive exfuncionário) que participaram diretamente destes procedimentos.

Tabela 4 - Empreendimentos FAR - PMCMV faixa 1 em Londrina

\begin{tabular}{cccrcc}
\hline Empreendimento & No Unidades & & Valor & Contratação & Construtora \\
\hline C H CRISTAL I & 232 & $\mathrm{R} \$$ & $10.593 .553,95$ & $30 / 12 / 2009$ & SIAL \\
\hline C H CRISTAL II & 248 & $\mathrm{R} \$$ & $11.324 .167,19$ & $30 / 12 / 2009$ & SIAL \\
\hline CJ RES MARAVILH & 60 & $\mathrm{R} \$$ & $2.496 .415,26$ & $30 / 12 / 2009$ & SIAL \\
\hline FLORES DO CAMPO & 1218 & $\mathrm{R} \$$ & $77.952 .000,00$ & $24 / 07 / 2013$ & FORMULA ENGENHA \\
\hline JD COLUMBIA I & 21 & $\mathrm{R} \$$ & $860.808,31$ & $24 / 05 / 2010$ & BONORA E COSTA \\
\hline NOVA ESPERANCA & 50 & $\mathrm{R} \$$ & $2.049 .999,87$ & $30 / 06 / 2010$ & BONORA E COSTA \\
\hline NOVA ESPERANCA3 & 61 & $\mathrm{R} \$$ & $3.171 .792,41$ & $27 / 01 / 2012$ & BONORA E COSTA \\
\hline QUATRO BAIRROS & 230 & $\mathrm{R} \$$ & $14.720 .000,00$ & $09 / 04 / 2013$ & TERRA NOVA \\
\hline RES ALEGRO VILL & 144 & $\mathrm{R} \$$ & $9.216 .000,00$ & $20 / 12 / 2013$ & G.FERDINANDI CO \\
\hline RES ANATERRA & 85 & $\mathrm{R} \$$ & $3.190 .939,18$ & $13 / 10 / 2009$ & BONORA E COSTA \\
\hline RES ELIZABETH & 32 & $\mathrm{R} \$$ & $1.311 .193,18$ & $08 / 07 / 2009$ & BONORA E COSTA \\
\hline RES N ESPERANCA & 100 & $\mathrm{R} \$$ & $4.099 .997,58$ & $30 / 09 / 2009$ & BONORA E COSTA \\
\hline VISTA BELA I & 305 & $\mathrm{R} \$$ & $13.053 .365,60$ & $30 / 09 / 2009$ & ARTENGE \\
VISTA BELA II & 208 & $\mathrm{R} \$$ & $9.406 .284,76$ & $30 / 09 / 2009$ & ARTENGE \\
\hline VISTA BELA III & 208 & $\mathrm{R} \$$ & $9.407 .083,54$ & $30 / 09 / 2009$ & ARTENGE \\
\hline VISTA BELA IV & 431 & $\mathrm{R} \$$ & $18.725 .178,20$ & $30 / 09 / 2009$ & TERRA NOVA \\
\hline VISTA BELA IX & 224 & $\mathrm{R} \$$ & $10.750 .008,42$ & $12 / 03 / 2010$ & ARTENGE \\
\hline VISTA BELA V & 224 & $\mathrm{R} \$$ & $10.130 .526,30$ & $30 / 09 / 2009$ & TERRA NOVA \\
\hline VISTA BELA VI & 536 & $\mathrm{R} \$$ & $23.269 .591,33$ & $30 / 09 / 2009$ & PROTENGE \\
VISTA BELA VII & 144 & $\mathrm{R} \$$ & $6.512 .448,33$ & $30 / 09 / 2009$ & PROTENGE \\
\hline VISTA BELA VIII & 224 & $\mathrm{R} \$$ & $10.749 .715,73$ & $12 / 03 / 2010$ & PROTENGE \\
VISTA BELA X & 208 & $\mathrm{R} \$$ & $9.981 .923,97$ & $12 / 03 / 2010$ & TERRA NOVA \\
\hline
\end{tabular}

Fonte: Caixa Econômica Federal

áreas fornecidas pela prefeitura por meio da Cohab-LD. Detalharei este caso adiante, no tópico "A ocupação insurgente do Residencial Flores do Campo". 
Figura 11 - Localização dos empreendimentos FAR - PMCMV faixa 1 em Londrina

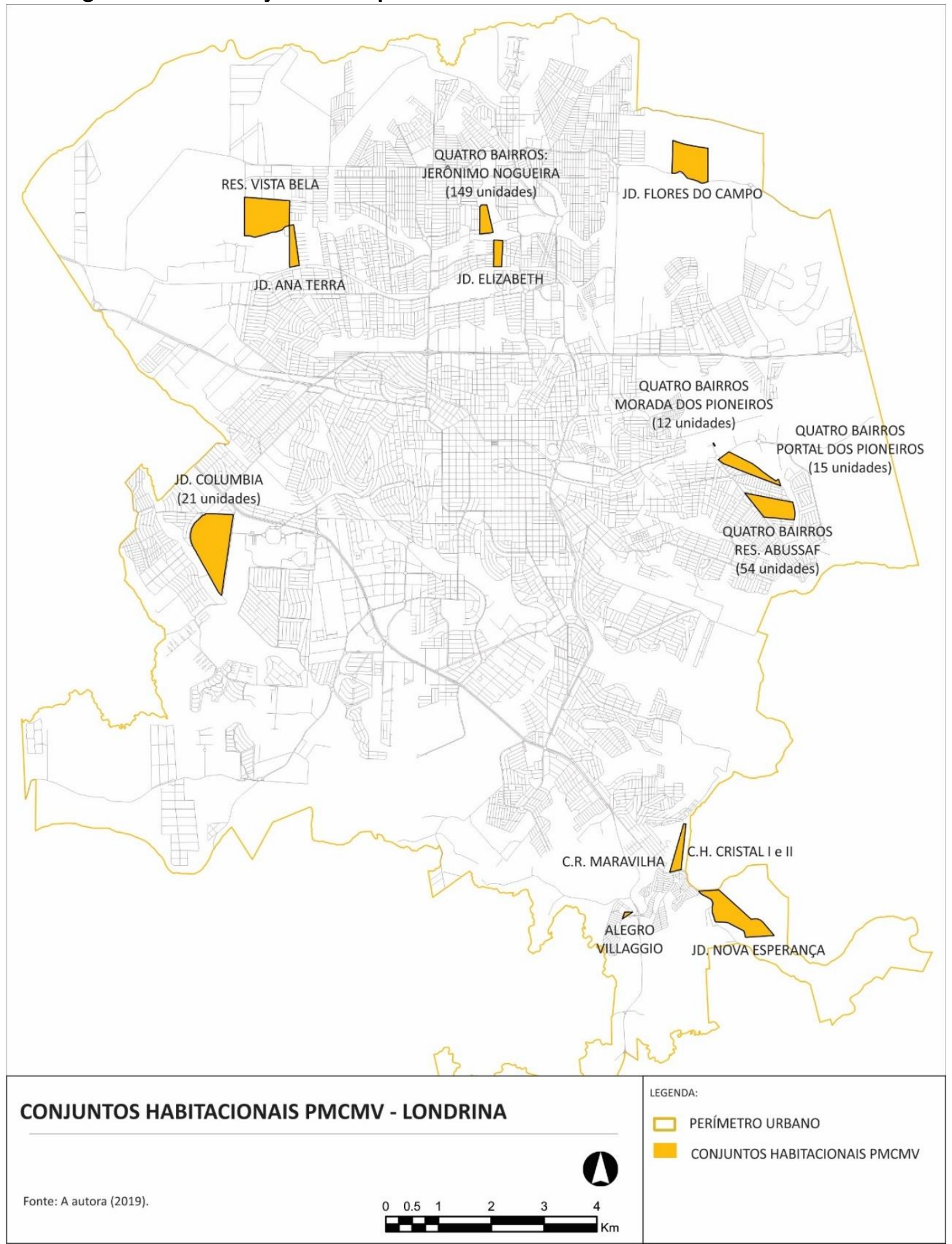

Fonte: Elaborado pela autora 
Observando a localização dos empreendimentos na Figura 11, é possível dizer que apenas o Jd. Elizabeth se destaca pelo aproveitamento de uma gleba vazia integrada à malha urbana. Os demais empreendimentos foram localizados em frentes de expansão na periferia, nos limites da malha urbana. Eles caracterizam-se pela localização periférica, como frentes de expansão urbana, pelas grandes glebas com muitas unidades habitacionais, ausência de equipamentos públicos, construções geminadas e apartamentos que criam uma paisagem profundamente homogeneizada reforçando seu aspecto segregador territorial e social.

A implantação do PMCMV em Londrina seguiu a mesma lógica de operação apontada anteriormente, destinando parte das unidades produzidas para famílias removidas de ocupações irregulares de diferentes partes da cidade. O procedimento da "mobilização" das famílias removidas será analisado destacando as escolhas das áreas de origem. $\mathrm{O}$ caso da zona leste de Londrina nos permite compreender a articulação do programa com o mercado de terras.

A localização do Residencial Vista Bela no limite da malha urbana, cercado por terrenos rurais e futuras áreas industriais evidencia a periferização e o papel de frentes de expansão provocadas pela implantação dos empreendimentos. Foi possível compreender o processo de escolha do terreno a partir de entrevista ${ }^{242}$ que recupera detalhes da implantação do empreendimento.

Além da localização periférica, o porte do empreendimento e a ausência de equipamentos públicos também são relevantes para compreender os efeitos socioterritoriais do programa. Estas características são resultado do estudo de viabilidade realizado pelas construtoras quando tiveram notícia da liberação de recursos pelo Governo Federal. O estudo de viabilidade não é exigência do PMCMV e foi iniciativa independente das construtoras locais que levantaram terrenos, contataram os proprietários e fizeram estudos quantitativos visando ter o controle sobre os contratos.

242 Entrevista realizada com funcionário da Cohab-LD - cargo comissionado - que trabalhou no Departamento de Programas Habitacionais no período de 2009 a 2016 . Esse funcionário é engenheiro, participou da concepção do projeto do parcelamento do solo do terreno quase dez anos antes e foi contratado para participar das negociações para implantação do Programa MCMV em Londrina. 
Desse modo, o estudo foi apresentado para a Caixa Econômica após a negociação com a proprietária do terreno, uma empresa paulista. No procedimento padrão para a contratação do empreendimento do PMCMV a Caixa Econômica faz a triangulação entre proprietário e construtoras.

O terreno do Res. Vista Bela possuía um projeto aprovado em 2002, o que agilizaria o processo de implantação tendo em vista a demora para aprovação de projetos na Secretaria de Obras e Pavimentação de Londrina e também baratearia o empreendimento já que não há previsão de doação de terrenos para implantação de equipamentos públicos 243 .

Como as normativas do PMCMV exigem a implantação dos equipamentos no caso da ausência ou insuficiência na região de implantação, essa questão foi solucionada no caso do Vista Bela com a assinatura de um Termo de Compromisso em que a Prefeitura liberou as construtoras da responsabilidade de prover os terrenos para esse fim, se comprometendo a implantar os equipamentos nas áreas do entorno do empreendimento e, como contrapartida, as construtoras ficaram com a responsabilidade de construir uma ponte na transposição de um Fundo de Vale no acesso sul do terreno, tendo em vista que o terreno encontrava-se isolado da malha urbana. Entretanto, logo após os trâmites do empreendimento, durante as obras, o prefeito foi cassado e apenas uma creche foi entregue, e após seis anos da entrega do

\footnotetext{
${ }^{243}$ Nas diretrizes de parcelamento do solo de 1998 há a exigência de doação de $3 \%$ da área parcelável da gleba para implantação de equipamentos públicos. No entanto, em 2018 foi denunciado um esquema de corrupção nos procedimentos de aprovação de loteamentos em Londrina, que era uma das causas da demora dos pareceres da SOP. A investigação do Ministério Público sobre o caso, chamada Operação ZR3, envolveu a Secretaria de Obras e Pavimentação, o Instituto de Pesquisa e Planejamento Urbano de Londrina, o Conselho Municipal da Cidade, a Secretaria de Meio Ambiente e a Câmara de Vereadores, e empresa privada de Planejamento Urbano que desenvolvia Estudos de Impacto de Vizinhança. Por meio de Lobby, era cobrada propina dos incorporadores para garantia dos projetos aprovados em tempo reduzido. O pagamento garantia alterações de zoneamento, agilidade na aprovação dos projetos, aprovação do Estudo de Impacto de Vizinhança, dentre outras coisas. Mais informações sobe esta operação, intitulada de Operação ZR3, pode ser acessada em: https://24horas.com.br/politica/operacaozr3-completa-um-ano-relembre-o-passo-a-passo-da-acao/;

https://paranaportal.uol.com.br/politica/vereador-afastado-e-preso-por-ameacar-testemunha-daoperacao-zr3/; https://cbnlondrina.com.br/materias/justica-comeca-a-ouvir-testemunhas-da-operacaozr3; $\quad$ https://www.folhadelondrina.com.br/politica/justica-marca-segunda-fase-de-depoimentos-daoperacao-zr3-1026725.html; https://www.folhadelondrina.com.br/politica/operacao-zr3---empresarioachacado-denunciou-suposta-organizacao-criminosa-na-camara-de-londrina-999042.html.
} 
empreendimento foi construída a primeira escola (entregue em 2017). Isso gerou uma grave situação na região devido à sobrecarga dos equipamentos públicos de bairros vizinhos, com vagas insuficientes e falta de atendimento para grande parte da população do Res. Vista Bela, considerando que o bairro possui mais de duas mil unidades residenciais onde residem mais de 12 mil pessoas.

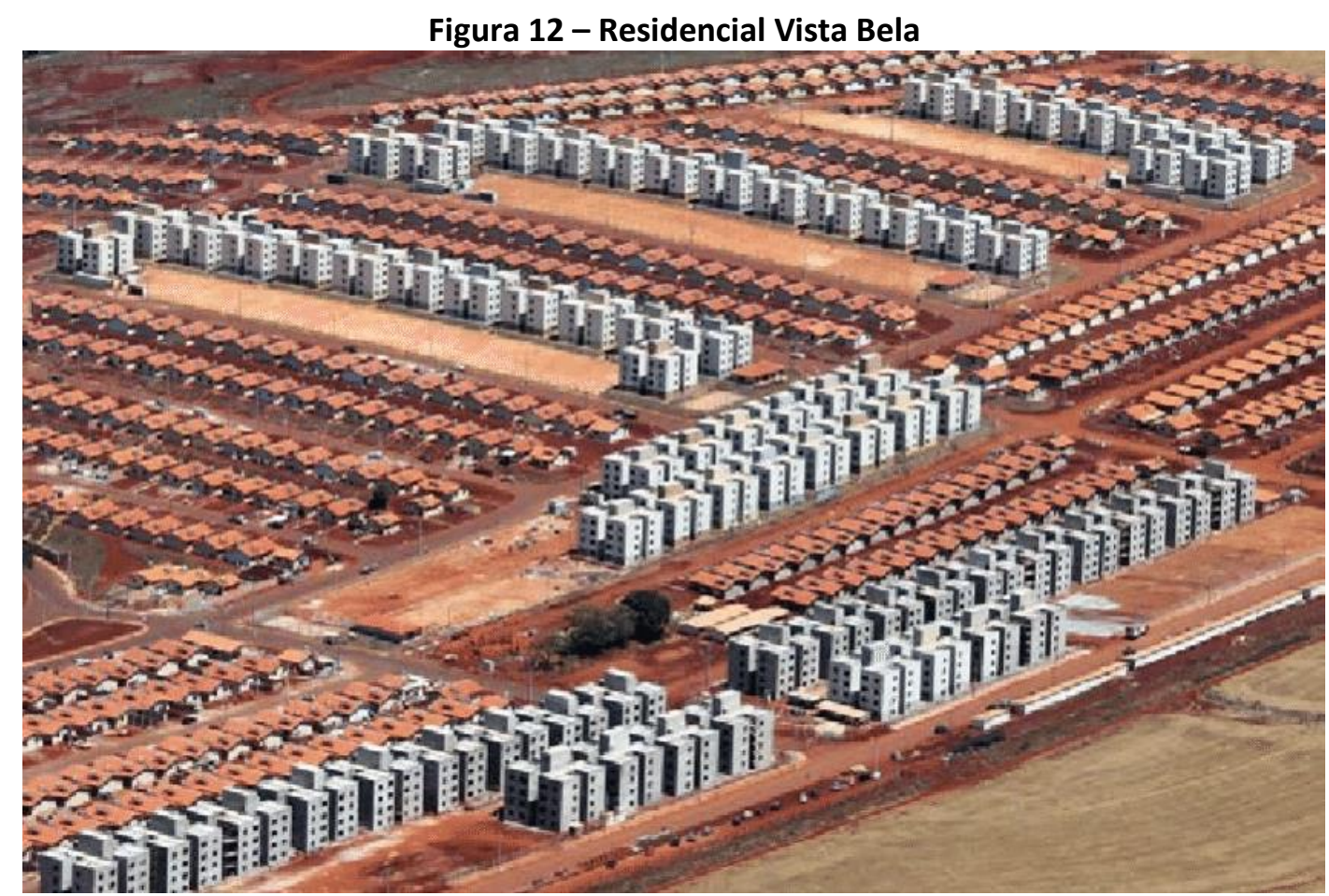

Fonte: Zanon, Cordeiro e Araujo Junior (2015).

Devido ao porte do terreno e os limites dos contratos da CEF foi feita uma espécie de consórcio entre três construtoras locais que assinaram dois contratos cada uma. Depois foram incluídos mais contratos, totalizando dez contratos referentes ao Residencial Vista Bela (Vista Bela I ao X). Na divisão, as construtoras menores ficaram responsáveis pela construção das casas, enquanto as construtoras maiores foram responsáveis pela construção dos prédios.

A operacionalização do Programa MCMV prevê que o município - em Londrina, a Cohab-LD - é responsável por fazer a distribuição das unidades para as famílias cadastradas. Na Lei no 11.977/2009 não estava previsto atendimento prioritário, que foi 
posteriormente incluído pela Lei $\mathrm{n}$ - 12.424/2011 para famílias residentes em áreas de risco (relacionados a acidentes) e priorizar o atendimento em nome da mulher. A CohabLD definiu seus próprios critérios priorizando o atendimento de famílias residentes em favelas, seguindo a lógica do desfavelamento.

\section{Uma prática chamada remoção de favela}

A palavra utilizada para os procedimentos das remoções de favelas é a "mobilização" das famílias residentes em ocupações irregulares ${ }^{244}$. Esse procedimento é de responsabilidade do Setor Social da Cohab-LD, que é gerido por uma diretora (assistente social), onde trabalham duas cientistas sociais, e mais dois assistentes sociais, dois cargos de indicação política e aproximadamente quatro estagiários por período. Quando há reintegração de posse, envolve outros setores também, e para gestão de programas financiados pode haver terceirização de outros profissionais.

O processo de seleção do PMCMV realizado em Londrina adotou como prioritárias as remoções de famílias ocupantes de Fundos de Vale/ocupações irregulares, seguindo a proposta de desfavelamento vista nas décadas anteriores ${ }^{245}$.

A equipe que fez a mobilização para o Res. Vista Bela não está mais na CohabLD, somente a diretora do Setor continua. Segundo ela, a seleção das famílias e das ocupações irregulares que deveriam ser removidas para o Vista Bela foi feita com base em informações contidas no PLHIS (2011) e no PEMAS (2002) já mencionadas,

\footnotetext{
${ }^{244} \mathrm{Em}$ primeiro lugar, importante diferenciar as remoções que são decorrentes de reintegração de posse dada em favor do proprietário, das remoções quando não há o respaldo da decisão judicial. Quando há reintegração de posse, a responsabilidade da desocupação é da polícia, mas a Cohab-LD, em alguns casos, participa fazendo uma ponte com a população para viabilizar a desocupação de forma "pacífica". Houve situações em que a Cohab-LD se responsabilizou em levar as famílias removidas pela reintegração de posse que foram instaladas em assentamentos em terrenos da companhia ou que estavam sendo adquiridos pela Cohab-LD. Mas o foco aqui são os procedimentos das remoções que não são resultados de reintegração de posse, que foram planejadas pela Cohab-LD com atendimentos das famílias pelo PMCMV.

245 Informações obtidas na entrevista concedida por uma funcionária que participou da seleção das famílias do Jd. União da Vitória para o Cristal I e II e para o Res. Maravilha.
} 
priorizadas as famílias que residiam em áreas de risco ${ }^{246}$. Segundo ela, o critério da territorialidade foi utilizado considerando Zona Norte como região para origem-destino das famílias, e no Cristal (I e II), Região Sul, principalmente, a porção do Jd. União da Vitória.

Para o trabalho de mobilização, por falta de profissionais no setor social, as equipes foram formadas contando com profissionais da Cohab-LD e profissionais de assistência social terceirizados. No caso do Res. Cristal I e II, foram formadas três equipes de mobilização. Para isso, foram contratadas três assistentes sociais terceirizadas que integraram estas equipes.

Segundo a entrevistada (e que pude confirmar durante minha permanência neste setor), as informações recebidas pelas equipes sobre o trabalho que será realizado são pontuais e objetivas e não possibilitam a interpretação da situação de forma mais ampla. As equipes recebem informações mínimas só para ir a campo coletar informações. Para a entrevistada "isso torna o trabalho penoso". É passado para a equipe o conjunto de critérios em que devem ser enquadradas as famílias e os documentos que devem providenciar para atender à solicitação da Caixa Econômica. $\mathrm{O}$ material utilizado para a mobilização consiste em um checklist de informações sobre as famílias e acompanha um "relatório social" com as observações do assistente social.

A ficha de atendimento do "Cadastro de Atendimento Social" solicita dados pessoais como: nome, data de nascimento e sexo, números dos documentos, estado civil, escolaridade, ocupação e renda do titular do cadastro e companheiro(a). Solicita também informações dos dependentes como nome, data de nascimento, parentesco, escolaridade, estado civil, ocupação e renda. Indica, no final, a somatória do total da renda familiar.

Com relação ao checklist, se algum membro da família tem problemas de saúde, se algum membro possui algum tipo de deficiência, e se algum membro da família utiliza algum equipamento especial (como cadeira de rodas ou muletas, por exemplo).

\footnotetext{
${ }^{246}$ Foram classificadas como áreas de risco todas as ocupações em fundos de vale.
} 
Quanto às características do domicílio e infraestrutura verifica-se a situação da posse/propriedade da moradia (comprada, alugada, cedida, ocupada irregularmente). Esta não é uma informação precisa, tendo em vista que alguns declaram que a casa é comprada, mas ela está localizada em área irregular, outros, mesmo tendo pago pela casa, declaram como ocupação irregular. Também é levantado o tempo de residência no local, se possui água encanada e energia elétrica e valores pagos mensalmente (não consta rede de esgoto), tipo de material da construção, tipo de material do piso da residência e uma classificação sobre a habitabilidade. Também identifica serviços públicos de saúde e assistência social onde a família é atendida, se recebe benefícios municipais ou federais e o número do cadastro de beneficiário. Por último, são levantadas as despesas mensais da família e o confronto com o valor total da renda. A essa ficha podem ser anexados relatórios do CRAS nos casos de famílias encaminhadas para atendimento prioritário.

Nas observações, o assistente social anota o que considera relevante complementar ou reforçar sobre a família. Na análise das fichas de cadastro das famílias atendidas no Res. Vista Bela, a quantidade e o tipo de informação colocada nas observações varia muito conforme o assistente social. Algumas fichas contam sobre aspectos da condição de vulnerabilidade da família em relação à mobilidade, violência, dificuldade de inserção no mercado, reclusão de membros da família, relação com tráfico de drogas, etc. Outras detalham alguns aspectos econômicos, como as fontes de renda formais/informais, condição dos móveis da família, etc. Algumas vezes aparecem informações complementares como a suspensão de algum benefício, ou problemas de despejo. As fichas vêm acompanhadas por um relatório fotográfico da casa.

Nos casos de ocupações em fundos de vale, o setor social estabeleceu como condição para o atendimento das famílias a autorização para a demolição do barraco assim que a família recebesse a casa no conjunto habitacional, portanto essa informação também constava nas fichas. Como não havia a reintegração de posse, a demolição foi negociada como uma forma de impedir a ocupação do fundo de vale após as remoções. Porém, algumas casas foram novamente ocupadas antes da demolição. 
Voltando ao trabalho da mobilização para a remoção para o conjunto habitacional, a entrevistada afirmou que se incomodava com a abordagem superficial e incompleta sobre o trabalho que seria desenvolvido, então procurou se informar por conta própria. Buscando novas informações descobriu que é opção da família sair da ocupação ou não, já que não houve reintegração de posse. Porém, ela afirmou que essa informação não foi passada à equipe e que na abordagem da diretoria foi indicado que a família deveria sair já que a área foi ocupada de forma irregular e que o município não fará a regularização naquele local. Sendo assim, quem escolhesse não sair para ir para os conjuntos do PMCMV, poderia vir a ter que sair em outro momento em que não seriam disponibilizadas vagas em conjuntos habitacionais e, nesses casos, a Cohab-LD não se responsabilizaria e a família teria que encontrar outro lugar sozinha.

Esta forma de colocar a questão, além de ocultar a informação de que existe a possibilidade de regularização fundiária ainda que ela não seja praticada em Londrina, mas que a reivindicação da usucapião é um direito das famílias que estão há mais de cinco anos e que existe a possibilidade legal de supressão da área de preservação permanente para viabilizar a regularização fundiária, a forma como a necessidade de sair do local "uma hora ou outra", sem o "apoio" da Cohab-LD tende a coagir as pessoas a aceitar a oferta. Assim, em nenhum momento estão claros os direitos e deveres e há uma distorção para convencer as famílias a concordarem com as remoções.

De acordo com a entrevistada, houve de fato alguma resistência em sair por parte de famílias que possuíam mais informações sobre o direito à moradia e os termos da usucapião. No caso do Jd. União da Vitória, algumas famílias tinham conhecimento de que parte da área ocupada irregularmente é de propriedade da Cohab-LD, que estava removendo as famílias sem reintegração de posse se beneficiando do seu papel de operadora da política habitacional.

No mapa usado para dar as explicações, que consistia no principal documento que norteava os trabalhos de campo do setor naquele núcleo, a entrevistada apontava para porções vazias no mapa dizendo onde estavam as famílias que residem em porções do terreno que são da Cohab-LD. Questionei o motivo das casas não estarem 
desenhadas no mapa, mesmo sendo ocupações antigas ela não soube responder. Porém, estas áreas correspondiam àquelas previstas para remoção das famílias.

Decorrente da falta de informação mencionada, os técnicos, quando confrontados a respeito dessas informações, não conseguiam argumentar. Porém, alguns técnicos insistiam que a área não poderia ser regularizada por se tratar de ocupação irregular. No entanto, como veremos adiante, cerca de dois anos após as remoções, em algumas dessas áreas as famílias que não tiveram interesse em sair conseguiram a regularização fundiária, o que levou a mais indignação por parte das famílias que já estavam residindo no conjunto habitacional.

Outro aspecto que a entrevistada chama a atenção em relação à abordagem da Cohab-LD no procedimento de remoção, é com relação aos apartamentos. Há muita resistência por parte das famílias para ir para apartamento, tendo em vista os hábitos e costumes (além das taxas condominiais). Muitas famílias que abandonaram o imóvel financiado para voltarem para as ocupações argumentaram a insatisfação com os apartamentos e as dificuldades financeiras para arcar com as taxas (não apenas as taxas de condomínio, mas como nas ocupações irregulares não são pagas energia elétrica, água, etc, a regularidade adiciona custos que até então não estavam nas despesas mensais das famílias).

A partir da análise das fichas das famílias removidas para o Res. Vista Bela, foi possível observar que há diferença significativa nas condições de vida das famílias que residem nas diferentes ocupações, desde renda, escolaridade, condição física da casa, etc.

Dentre as famílias que residiam em ocupações irregulares e foram removidas para o Res. Vista Bela, parte estava desempregada, grande parte ocupada no mercado informal e parte empregada formalmente. De um modo geral, a maioria oscila entre diferentes trabalhos, formais e informais com períodos de desemprego. Poucos eram os casos de pessoas que ficaram no mesmo emprego por muito tempo. Os trabalhos informais predominantes são de empregadas domésticas, principalmente diárias de faxina, no setor da construção civil - também em diárias -, moto táxi e segurança. Os 
trabalhadores registrados enquadravam-se, na maioria das vezes, nos cargos de serviços gerais, fiandeiras e costureiras.

Entre os contemplados, há famílias numerosas, alguns casais sem filhos (principalmente idosos), mas a maioria são famílias de aproximadamente quatro pessoas chefiadas pela mulher (esse foi um dos critérios para o atendimento). Funcionários da Cohab-LD e pesquisadores afirmam que muitas famílias optaram por não formalizar a união estável entre o casal para se enquadrarem nesta categoria prioritária de "mãe chefe de família". Nos relatórios sociais foi possível ver se existia um companheiro ou não, independente do que foi declarado para a Caixa Econômica Federal. De um modo geral, observa-se que predominam famílias monoparentais.

A escolaridade dos chefes de família também chamou a atenção. $O$ analfabetismo era predominante nos idosos. Porém a escolaridade mais baixa estava entre os idosos e os mais jovens, na faixa dos 20 a 30 anos. Os adultos, acima de 40 anos possuíam escolaridade mais alta (fundamental completo e ensino médio incompleto). Considerando a época da coleta dos dados (entre 2009 e 2011), conclui-se que na década de 90 houve aumento da evasão escolar.

Grande parte dos idosos migrou do Nordeste ou da região de São Paulo, enquanto entre os adultos entre 40 e 50 anos a maior parte migrou de cidades menores - principalmente da área rural - do próprio norte do Paraná. Já entre os mais jovens, a maioria cresceu em ocupações irregulares ou conjuntos habitacionais e mudaram para uma ocupação irregular quando tiveram o primeiro filho. Ainda, mesmo entre os que migraram para Londrina, poucas são as famílias que residiram em favelas desde que chegaram na cidade. A maior parte das famílias passa pouco tempo nas casas, migrando entre ocupações com intervalos em casas de aluguel. Isso indica que, assim como afirma Pasternack (2008, p.103) é um mito que as famílias chegam de outras cidades direto para as ocupações irregulares.

Apesar de ser possível uma análise que diferencia as necessidades das famílias que são bastante heterogêneas, os relatórios são sempre reduzidos a dados quantitativos com a finalidade de enquadrar as famílias nas categorias de prioridades. 
Estas características também não foram consideradas na distribuição das famílias nas casas do bairro, marcadamente homogêneo. A solução apontada pela Cohab-LD como forma de "minimizar" o impacto dos deslocamentos das diferentes regiões da cidade, as famílias oriundas das mesmas ocupações foram locadas em uma mesma quadra dentro do bairro. Sendo assim, de forma aproximada, cada quadra foi ocupada por famílias originárias da mesma favela.

Como o Vista Bela foi entregue em etapas, as remoções aconteceram de acordo com a periodicidade destas entregas. As casas de esquina foram reservadas para portadores de necessidades especiais, principalmente cadeirantes, e idosos. As primeiras famílias removidas foram para as casas, considerando o agrupamento mencionado. Outras famílias foram removidas para apartamentos, resultando em incompatibilidades de diferentes naturezas. Primeiro, os gastos com as taxas de condomínio somadas ao financiamento, e as demais contas tornaram-se inviáveis para as famílias mais vulneráveis e gerou descontentamento, inadimplência e retorno às ocupações $^{247}$.

A mobilização em áreas que seriam ser removidas para o Res. Vista Bela começou em 2009 e teve como foco as ocupações irregulares localizadas em fundos de vale, com base nos levantamentos do PEMAS (2002) e do PLHIS (2011). Porém, a mobilização foi realizada em todos os bairros onde estão localizadas estas ocupações irregulares em áreas de preservação permanente, e não apenas com as famílias residentes em fundos de vale. Como a mobilização atingiu a todos esses bairros, famílias que pagavam aluguel nesses bairros ou residiam em casas cedidas também foram atendidas. Portanto, o público-alvo foi selecionado a partir da localização das áreas, fato que será explorado mais adiante.

\footnotetext{
${ }^{247} \mathrm{O}$ caso mais emblemático que ficou conhecido foi de um morador que foi removido de uma favela para um apartamento e foi proibido de deixar seu cavalo no estacionamento do condomínio. Este é apenas um exemplo da incompatibilidade das características culturais dos diferentes tipos de ocupação irregular que foram removidos para um espaço homogêneo produzido sob uma lógica que ignora os aspectos humanos da moradia.
} 
Figura 13 - Origens das famílias removidas para o Res. Vista Bela

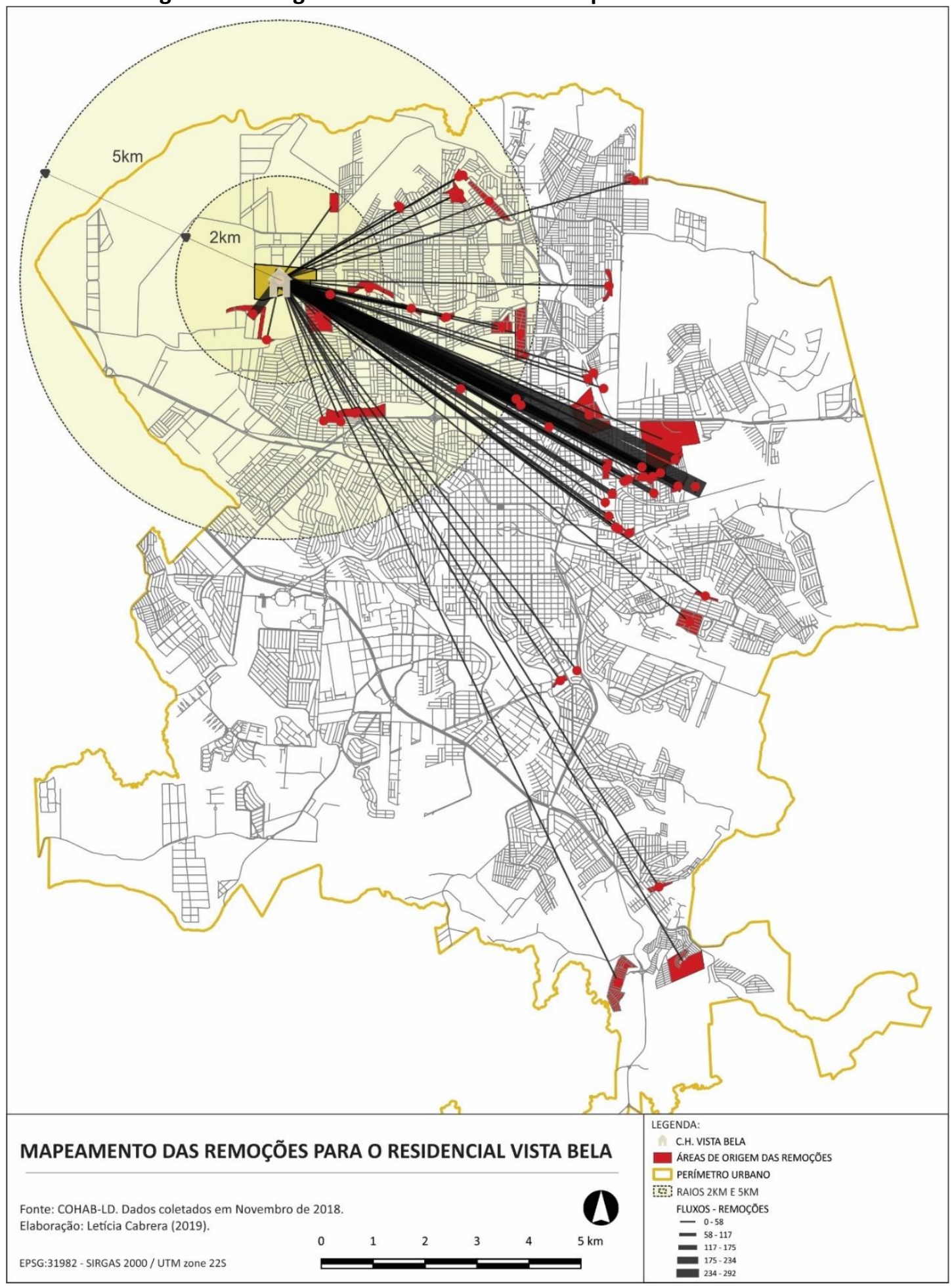

Fonte: Elaborado pela autora. Montagem: Letícia Cabrera 
A concentração de remoções na zona leste é evidente e contradiz as falas de que o princípio da territorialidade foi respeitado para a seleção das famílias.

Muitas dessas áreas surgiram como assentamentos irregulares desenvolvidos pela própria Cohab-LD a partir de remoções de famílias de outras áreas, principalmente de preservação permanente. Estes assentamentos se consolidaram e adensaram, chegando a ter as suas áreas de fundos de vale ocupadas, e se tornaram alvos das mobilizações para remoção das famílias para o Res. Vista Bela. Grande parte deles estava localizada na região leste de Londrina, o que levanta uma questão importante para a análise, tendo em vista que o Res. Vista Bela está localizado na porção norte da cidade, no extremo oeste da malha urbana. Por isso, busco compreender melhor as razões da prioridade em remover assentamentos localizados na zona leste da cidade.

Em primeiro lugar, estas áreas estão muito distantes - ultrapassando $10 \mathrm{Km}$ - do bairro de destino, o que fere as premissas de territorialidade ${ }^{248}$. Além disso, são áreas muito próximas do centro da cidade e de bairros consolidados.

Zona leste: de destino a origem das famílias

A porção leste de Londrina foi alvo de ocupações irregulares desde a década de 1950, em áreas marginais às principais vias de circulação e próximas às áreas industriais. Como visto no capítulo anterior, durante a década de 1990, frente à baixa de investimentos em produção de habitação de interesse social, a administração municipal reconhecida por práticas populistas que utilizava a produção de habitação de interesse social como "mercadoria política", passou a remover as famílias que residiam irregularmente em áreas de fundos vale para terrenos da Cohab-LD. Essas práticas deram origem aos chamados "assentamentos urbanos" que se assemelhavam muito às

\footnotetext{
248 Considerando a abordagem de Kowarick (2002) sobre a noção de vulnerabilidade e risco da vida na periferia, outros fatores deveriam ser considerados para embasar a escolha das áreas de remoção. $A$ territorialidade é um fator fundamental tendo em vista que as redes de solidariedade que se formam nos bairros, a proximidade com o local de emprego, ambientação das crianças nas escolas, proximidade das residências de familiares, etc, são aspectos que influenciam nos graus de vulnerabilidade das famílias e, portanto, também deveriam ser considerados.
} 
favelas devido às habitações precárias e à ausência de infraestrutura urbana. Nesse período, grande parte das remoções de favelas foi realizada para assentamentos na região leste da cidade, como é o caso do Jd. Santa Fé, do Jd. Morar Melhor, do Jd. Santa Inês, e do Jd. Santa Mônica. Portanto, é possível afirmar que a região leste foi, durante esse período, destino de famílias removidas de favelas de outros locais.

O fato das ocupações irregulares terem sido toleradas pelo poder público municipal que, depois, promoveu os assentamentos também nessa mesma região deve estar associado ao fato de que essa porção de terra não fazia parte dos limites do município de Londrina no início da ocupação e, por isso, não foi incorporada ao parcelamento promovido pela Cia de Terras. Até meados de 1955, a porção que foi ocupada irregularmente não fazia parte da delimitação da colonização da Cia de Terras do Norte do Paraná249. No mapa da Figura 14 é possível ver o limite entre as terras de propriedade da Cia de Terras e de Francisco Beltrão, que marca exatamente o limite da área das ocupações.

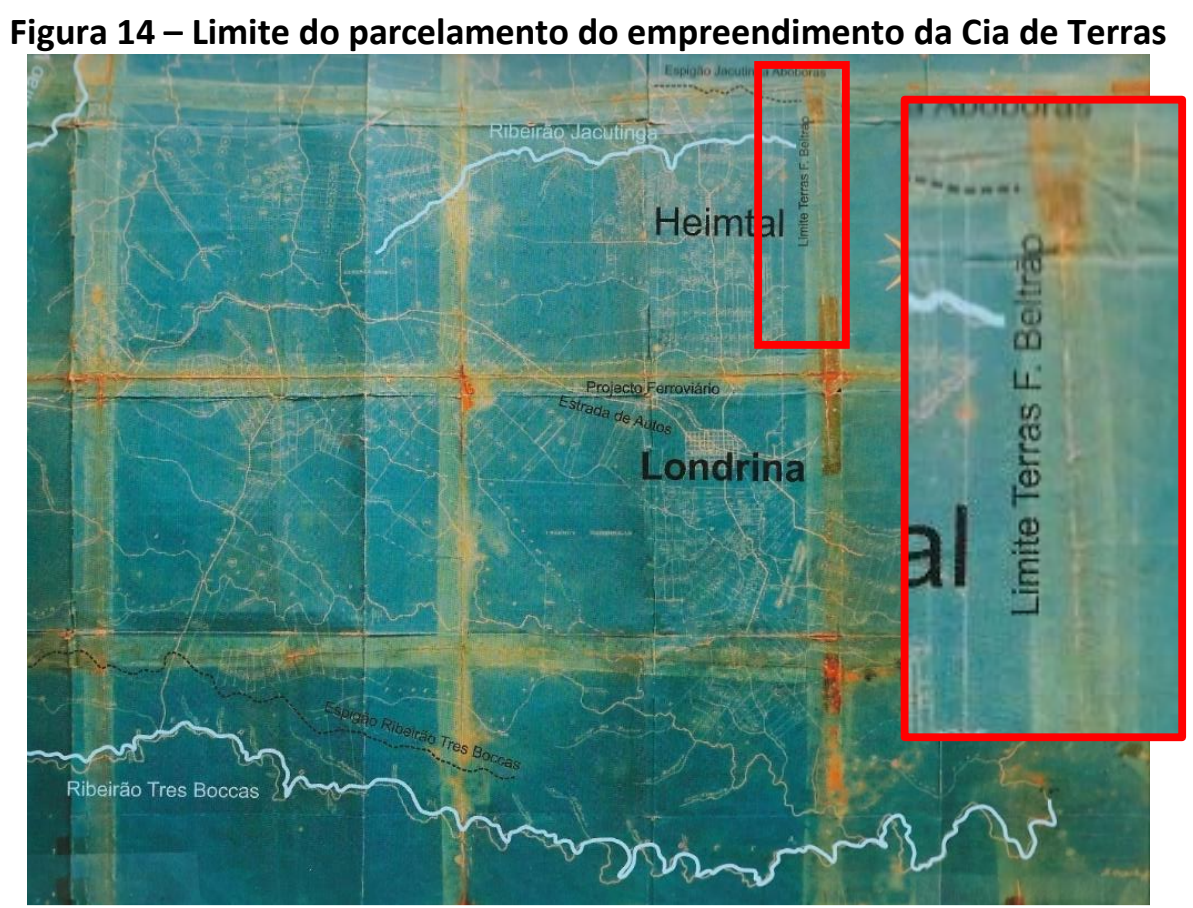

Fonte: Yamaki (2017), modificado pela autora.

\footnotetext{
${ }^{249}$ Estes mapas podem ser encontrados em Yamaki (2003) e Yamaki (2017).
} 
Devido aos assentamentos formados nessa região e às ocupações irregulares que cresceram sem intervenções significativas do poder público municipal e aos grandes terrenos em que se localizavam indústrias e barracões que ficaram subutilizados com o passar dos anos, a região leste de Londrina possuía caráter de periferia, onde predominavam residências de baixa renda, comércio de autopeças, favelas, etc.

No início da década de 2000, começam a aparecer projetos de Lei para alteração do zoneamento daquela região. Chamou a atenção o fato desta área ter sido alvo de intensos investimentos nas últimas duas décadas, passando pelo que Amorim (2011) chamou de reestruturação imobiliária. Foram levantados os projetos de alteração de zoneamento da área ${ }^{250}$, o que mostra que o poder público teve um papel fundamental na reestruturação imobiliária, que resultou em uma valorização exponencial dos terrenos da zona leste. Atualmente, está em construção um viaduto no local para solucionar os problemas de fluxo gerados pela implantação de um grande empreendimento (Shopping Center).

Apesar de não ter sido promovido um projeto de revitalização ${ }^{251}$ para a área, as mudanças que ocorreram nas últimas duas décadas tiveram caráter de renovação. Todo esse planejamento é impulsionado por uma engrenagem articulada entre o poder público e o poder privado tanto na definição dos objetivos como na execução das ações ${ }^{252}$. É nesse sentido que os empresários se incluem nos processos de decisão e

\footnotetext{
${ }^{250}$ Ao todo, foram levantados 43 processos de alteração de zoneamento na região a partir de 1999, quando começam os primeiros investimentos na área. As principais alterações se referem à passagem de Zona Residencial 3 - com parâmetros para produção de bairros residenciais de padrão econômico - para Zona Comercial 6, elevando o potencial construtivo dos terrenos e permitindo um grande leque de usos comerciais, residenciais (verticais) e de serviços.

${ }^{251}$ O estigma da cidade-empresa tem sido assimilado por meio do "espetáculo urbano" promovido em torno das obras de revitalização, requalificação, etc., e se tornou uma ferramenta de controle social (Arantes, 2012). A intenção é que toda a cidade assimile esse processo culturalmente para que se torne um consenso, no sentido do "crescimento a qualquer preço" (Arantes, 2012, p. 18). Tendo o poder público municipal incorporado todas essas medidas, isso "(...) implica a direta e imediata apropriação da cidade por interesses empresariais globalizados e depende, em grande medida, do banimento da política e da eliminação do conflito e das condições de exercício de cidadania" (Vainer, 2000, p. 78). A cidade (o espaço urbano) sendo tratada como mercadoria é posta à venda por seus governantes (Borja e Forn, 1996 apud Vainer, 2000). Em decorrência disto, o marketing urbano é apreendido cada vez mais como ferramenta determinante tanto para o planejamento urbano como para a gestão urbana. Em conformidade com as vocações comerciais de cada cidade é definido o que será colocado à venda e construída uma imagem da cidade (Vainer, 2000) responsável por atrair os investidores.

252 Vainer (2000).
} 
interferem diretamente no planejamento em termos de obras públicas e direcionamento dos investimentos. Dessa forma, com o poder público municipal infectado com a lógica empresarial, seja pela associação direta com outras empresas, seja planejando suas ações como uma empresa que tem uma mercadoria a vender, o espaço urbano, interfere na produção desse espaço com objetivos estritamente mercantis. Nesse novo momento, portanto, associa-se às conhecidas práticas de periferização da pobreza, hegemonia do mercado, etc., uma gentrificação completa da cidade $^{253}$, aceita devido à assimilação cultural do "espetáculo urbano".

${ }^{253}$ Arantes (2012). 
Figura 15 - Empreendimentos lançados a partir da década de 2000 na zona leste de Londrina.

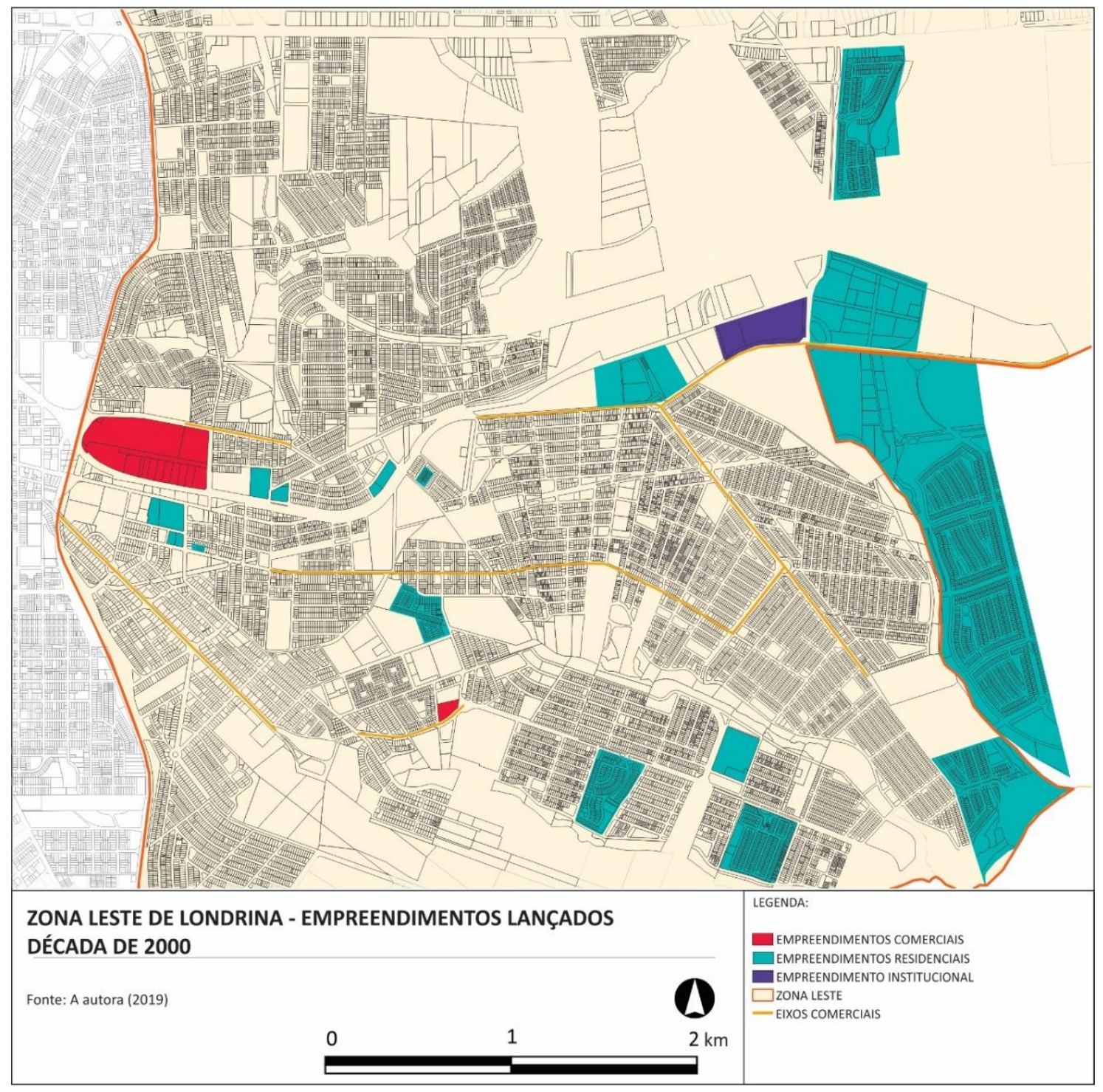

Fonte: elaborado pela autora.

A Figura 15 mostra os empreendimentos lançados nas últimas duas décadas na zona leste de Londrina, indicando a reestruturação imobiliária pela qual passa a região. Os empreendimentos levantados são residenciais, horizontais e verticais, principalmente no formato de condomínio; comerciais, correspondentes ao Complexo Marco Zero, que concentra um Shopping Center, Hotel, Loja de departamento, hipermercado e um teatro, e eixos comerciais criados nas principais vias de circulação. Essa valorização imobiliária pode ser uma justificativa - perversa - para a opção pela 
remoção dos assentamentos precários dessa área. A fala de Amorim (2011, p.129) ilustra a transformação e a visão empresarial sobre a zona leste.

O Complexo Marco Zero irá se constituir num centro empresarial, cultural e comercial, pois, abrigará: o Teatro Municipal; o Shopping Boulevard com mais de 300 lojas, 12 salas de cinema, sete lojas âncoras; um hipermercado; um centro de convenções para três mil pessoas; sete torres comerciais e residenciais; além de outros empreendimentos privados. As condições necessárias para sua viabilização foram criadas pela iniciativa privada, sobretudo, pela intermediação de incorporadores locais na gestão do empreendimento. Contudo, o poder público, ao assegurar a construção do Teatro Municipal no local - o que se deu após longa polêmica por conta de localizá-lo ao lado de um grande empreendimento privado -, tornou ainda mais interessante e possível a viabilidade do empreendimento todo. Além da presença do poder público local na construção do futuro Teatro Municipal no mesmo local, há também empresários da cidade e de outros lugares, como por exemplo, o Grupo Wal Mart que atuará no local com a implantação de um hipermercado. A Raul Fulgêncio - Negócios Imobiliários, o grande grupo gestor de toda a obra, está desde o início das negociações na vanguarda das decisões, foi este grupo quem, inclusive, adquiriu o terreno doando parcela à PML, para a construção do Teatro Municipal. Os incorporadores responsáveis pela construção e gestão do Complexo Marco Zero encontraram como alternativa mais viável a edificação do complexo no terreno da antiga refinaria de óleo de soja Anderson Clayton, seja pela viabilidade logística, pela proximidade com o centro da cidade, mas, também, não menos importante, em função da pouca disponibilidade de terras baratas com localização "privilegiada" em termos centrais na cidade.

Os empreendimentos residenciais focalizados na faixa de renda média (predominantemente condomínios fechados horizontais e verticais) lançados na região mostram que a área passa a ser habitada por uma população de renda média e médiaalta que migra de outras porções da cidade devido aos novos investimentos no local. Esse processo de valorização imobiliária pode gerar a gentrificação da população de renda mais baixa que ainda reside na área. Isto, somado às remoções dos assentamentos precários promove a expulsão dos pobres do local.

Um fato que valida todas estas suspeitas é a condenação, em 2019, da Promotora de Meio Ambiente e o empresário proprietário de uma construtora por 
improbidade administrativa devido à insistência com órgãos públicos para aprovação de um projeto de loteamento do PMCMV para a zona leste de Londrina requerida em 2011. Segundo dados da Cohab-LD, o terreno em que seria inserido o empreendimento estava ocupado irregularmente pela favela "Morro do Carrapato" desde 2007. Na época dos crimes, em 2010, a promotora condenada atuava na Promotoria do Meio Ambiente e pressionou, junto com o empresário, os órgãos públicos responsáveis pela aprovação do projeto do empreendimento e, segundo a reportagem do caso ${ }^{254}$, uma servidora da Cohab-LD também foi pressionada para agilizar a liberação do empreendimento que dependia da remoção da favela do local. Os moradores da favela "Morro do Carrapato" foram removidos para o Res. Vista Bela.

Uma parte dos moradores não saiu durante a mobilização para o Res. Vista Bela, e a reintegração de posse do Morro do Carrapato aconteceu em 2015. Em 2013 residiam 22 famílias no local, em 2014, 44 famílias e em 2015, quando ocorreu a reintegração, residiam 52 famílias. As famílias que passaram pela reintegração de posse foram residir em um Fundo de Vale nas proximidades do terreno ${ }^{255}$.

Depois disso, a área foi novamente ocupada. Em 2018 uma reportagem ${ }^{256}$ registrou uma tentativa de forçar os atuais ocupantes a deixar o local por meio de violência física.

Está todo mundo sem roupa aqui, só com a roupa do corpo, sem documento, sem nada. Falaram pra gente que quem não sair por bem, vai sair por mal", relatou um dos moradores que reside há 8 anos na ocupação e não quis se identificar. Os moradores e moradoras relatam também que os agressores vestiam máscaras, são todos homens e usavam carro com placa de Cambé, de uma empresa particular de segurança chamada Força Impactus Segurança. Na manhã de sábado (17/02), o Ministério Público foi acionado para que tomasse medidas para garantir a segurança dos moradores da Ocupação. A promotora da 4 ㅇ Promotoria de Justiça, Sandra Regina Koch, estava de plantão no

\footnotetext{
254 Reportagem disponível em: https://www.folhadelondrina.com.br/geral/promotora-e-condenada-apagar-multa-de-r-100-mil-por-favorecimento-a-empresarios-2956203e.html. Acesso em: 30/10/2019.

255 Dados extraídos de reportagem disponível em: https://pretextouel.com/2016/07/02/morro-doscarrapatos-continua-na-luta-por-moradias-dignas/. Acesso em: 26/10/2019.

${ }^{256}$ Reportagem de Mídia Ninja para o site do MTST. Disponível em: https://mtst.org/noticias/moradoresda-ocupacao-morro-dos-carrapatos-sao-espancados-e-tem-barracos-incendiados-em-londrina-pr/. Acesso em: 26/10/2019.
} 
sábado e encaminhou ofício ao Comandante do 5o Batalhão da Polícia Militar para que intensificasse o patrulhamento na área onde fica a Ocupação do Morro dos Carrapatos. Porém, o pedido de patrulhamento não foi atendido, tanto que a violência perversa dos agressores mascarados continuou.

A principal justificativa da Cohab-LD para a escolha da zona leste como prioridade nas remoções para o Res. Vista Bela é que essa região concentrava o maior número de ocupações irregulares em áreas de preservação permanente ${ }^{257}$.

A escolha em priorizar famílias nessas condições também foi definida pela Cohab-LD. Essa diretriz ainda não existia na Lei no 11.977/2009, mas foi incluída em 2011 pela Lei Federal no 12.424/2011 após a Portaria № 610 de 2011. Cabe o destaque de que a prioridade que ficou definida pela Lei contempla moradores de áreas de risco e insalubres, sem mencionar se é área de preservação permanente ou não. Novamente, retomo o fato de que os fundos de vale em Londrina possuem $60 \mathrm{~m}$ de área livre a partir do córrego, sendo $30 \mathrm{~m}$ de APP e mais $30 \mathrm{~m}$ de faixa sanitária para contribuir para a drenagem. Portanto, dependendo do local da ocupação nestas faixas, as moradias não estão localizadas sobre os 30m de APP. Na faixa sanitária a inclinação do terreno não inviabiliza necessariamente as construções, o que possibilitaria a implantação de infraestrutura e a construção de casas de forma segura, como foi feito no Jd. Rosa Branca ${ }^{258}$.

A seleção das famílias que foram removidas para o residencial Vista Bela ocorreu entre 2009 e 2011, dois anos antes da concepção do Programa de Regularização Fundiária (2013), portanto a mobilização foi feita independentemente da possibilidade de promover a regularização fundiária. Como foi comentado, no caso das remoções do Jd. União da Vitória para o Res. Cristal diversas famílias que optaram por não sair conseguiram a regularização fundiária posteriormente, o que gerou indignação de alguns moradores que se mudaram para os apartamentos. Ainda, algumas remoções

\footnotetext{
${ }^{257}$ Não encontrei dados na Cohab-LD ou de outras fontes que pudesse confirmar ou refutar que a região leste possui maior número de famílias vivendo em áreas de fundos de vale ou outro tipo de área de preservação permanente em relação às demais regiões.

258 O chamado Setor Sul do Jardim Rosa Branca foi urbanizado na década de 90, suprimindo cerca de $50 \%$ da faixa de $30 \mathrm{~m}$ correspondente à Área de Preservação Permanente.
} 
ocorreram em terrenos da própria Cohab-LD, sem que houvesse pedido de reintegração de posse.

Entretanto, a priorização da zona leste relacionada ao processo de reestruturação imobiliária, pode ser interpretada a partir dos conceitos de produção "não mercantil" e "abertura da terra para o fluxo de capital". Pirez (2016), em análise sobre a urbanização latino-americana, define como produção não mercantil os processos de urbanização que não passam pelo mercado e, entre elas, ele enquadra a produção realizada diretamente pelo Estado. Neste caso, diferentemente da produção de unidades habitacionais comercializadas pela Cohab-LD, os assentamentos da zona leste de Londrina foram produzidos à margem do mercado imobiliário. Porém, o que se observa nessa área nas últimas décadas é o interesse do mercado em abrir uma nova frente de expansão do mercado imobiliário que, como coloca Harvey (2013), conta com o Estado para garantir a abertura da terra aos fluxos de capital.

Flores do Campo: uma ocupação insurgente

A Ocupação Flores do campo teve início com um grupo de pessoas que souberam do abandono da obra do Conjunto Habitacional Flores do Campo, que se encontrava em fase de construção com recursos do PMCMV. No início, a ocupação possuía aproximadamente 400 famílias. Dentre elas, havia famílias de outras ocupações, que passaram por reintegração de posse, que foram despejadas, de cidades vizinhas, entre outros. As famílias ocuparam as casas sobrepostas e os prédios, construíram um barracão para reuniões e improvisaram a infraestrutura que ainda não existia no local. Como o bairro é muito afastado, o desvio da rede de infraestrutura é muito mais difícil do que em ocupações em fundos de vale ou em vazios urbanos. Ainda, alguns moradores me relataram que quando furaram o solo em frente à casa para cavar a fossa sanitária, brotou água a pouco mais de um metro de perfuração, dando indícios de que o terreno é alagadiço. 
O terreno do Flores do Campo está localizado à leste, na porção norte da área urbana de Londrina, como visto na Figura 11. O contrato da construção foi de $\mathrm{R} \$$ 77.952.000,00 para a construção de 1.218 unidades $^{259}$, mas a construção não foi concluída, pois a construtora responsável abandonou a obra ${ }^{260}$. Segundo a Caixa Econômica Federal, a obra não chegou a 50\% da conclusão. Apesar do terreno ser da CEF, a fiscalização da obra é de responsabilidade do município.

Apesar de edifícios e residências sobrepostas terem sido construídas, não foi construída a infraestrutura subterrânea do loteamento. Esse fato, juntamente com as características do terreno úmido e em declive, próximo a um fundo de vale, tem levado a um deslizamento de terras nas linhas de drenagem do terreno e em direção ao fundo de vale. Isso coloca os moradores da área em situação de risco, já que a contenção dessa terra está sendo feita por um muro de arrimo muito extenso e que se encontra abaulado, indicando movimentação do terreno. Devido a essas movimentações de terra, as construções sem fundação da parte mais baixa do conjunto tiveram de ser desocupadas, assim como os edifícios.

As obras foram paralisadas no começo de 2016 e a ocupação do conjunto habitacional ocorreu em 1 으 de outubro de 2016. Além do grande número de famílias, a ocupação recebeu apoio de diferentes entidades, ganhando expressividade, um fator decisivo para o curso das negociações entre ocupação e poder público ${ }^{261}$.

A reintegração de posse foi solicitada pela Caixa Econômica Federal (proprietária do terreno), e o despejo foi determinado em 16 de novembro de 2017. Às vésperas do cumprimento, a reintegração de posse foi suspensa pelo desembargador do Tribunal

\footnotetext{
259 Dados da Caixa Econômica Federal (2016).

260 De acordo com Caldeira (2019), as obras foram suspensas devido à falta de repasses dos pagamentos por parte da Caixa Econômica Federal.

${ }^{261}$ Segundo Caldeira (2019), a articulação entre movimentos sociais, entidades e ocupação resultou na construção de uma rede de apoio à ocupação Flores do Campo. A autora aponta os movimentos sociais Coletivo Mobiliza Londrina, Fórum Basta de Violência, e o Movimento dos Trabalhadores e Trabalhadoras por Direitos, relativamente recentes e que aparecem pela primeira vez articulados em torno de uma mesma causa. Esse fator mostra a importância adquirida pela ocupação no campo da luta pela moradia em Londrina. Até então, as ocupações ocorrem de forma fragmentada, situação que favorece o controle dos conflitos por parte do Estado.
} 
Regional Federal da 4a Região. Outras ações ocorreram, mas, novamente, o despejo não aconteceu.

Tendo em vista que a suspensão da reintegração de posse esteve relacionada ao fato de que os moradores da ocupação não teriam para onde ir após a desocupação, o Ministério Público "forçou" negociações entre os ocupantes e a prefeitura. Neste período, a prefeitura deu início às negociações, oferecendo um terreno para abrigar provisoriamente os ocupantes até, segundo o presidente da Cohab-LD, os moradores serem atendidos em algum programa habitacional.

Como o terreno oferecido não tem área suficiente para abrigar o total de famílias, agora já em número bastante reduzido ${ }^{262}$, as negociações caminharam para a busca de um novo terreno para abrigar o restante dos moradores. Durante essas negociações, foram realizadas reuniões envolvendo todos os interessados: PML, CohabLD, entidades parceiras da ocupação, empresas que prestam serviços públicos, universidades ${ }^{263}$, igreja católica e movimentos sociais.

Algumas declarações do presidente da Cohab-LD 264 mostram que o diálogo entre a Companhia e a ocupação não foi amigável e desmoralizam a ocupação perante a opinião pública.

\footnotetext{
${ }^{262}$ Após confrontos com a polícia na tentativa de desocupação do conjunto habitacional, muitas famílias começaram a deixar o local.

${ }^{263}$ Participei de grande parte dessas reuniões como colaboradora do Projeto de Extensão "Apoio à análise de Estudo de Impacto de Vizinhança" do curso de Arquitetura e Urbanismo da Universidade Estadual de Londrina. Este projeto de extensão foi contatado por entidades parceiras da ocupação para elaborar o projeto de parcelamento da área para onde seriam transferidas as famílias.

${ }^{264} \mathrm{Em}$ entrevista, o presidente da Cohab-LD declarou que em "muitas das ocasiões não conseguimos entrar no empreendimento e também teve os que não demonstraram interesse em se cadastrar, por estar faltando algum documento, como RG, CPF, ou até mesmo por uma possível pendência na Justiça, que poderia se evidenciar com o cadastro", mostrando que não houve diálogo efetivo entre companhia e ocupação. Diz ainda que "Existem casos de famílias que foram contempladas em outro programa habitacional, mas preferem alugar aquele imóvel e continuar ocupando o Flores do Campo. Infelizmente isso existe. Das pessoas com registro formal e as que ganham acima de dois salários, elas podem procurar um imóvel e não se sujeitar à uma situação dessa", sugerindo que as famílias não estão na ocupação apenas por necessidade. Há, de fato, relato de mulheres que saíram do Residencial Vista Bela, devido à violência doméstica. Entretanto, da forma como está posto, coloca em dúvida os objetivos dos ocupantes. Informações coletadas da reportagem disponível em: https://www.bonde.com.br/bondenews/londrina/cohab-coleta-informacoes-de-familias-do-flores-docampo-460441.html. Acesso em: 30/10/219.
} 
Desde o início da ocupação, a Prefeitura do município e a Cohab-LD se posicionaram com o argumento de que a questão não era de atribuição do município, já que o terreno é de propriedade da Caixa Econômica. Depois da segunda suspensão da reintegração de posse, foi formado um grupo de trabalho para buscar soluções para a realocação dos moradores. A prefeitura se responsabilizou pela doação do terreno, a ser desafetado para a Cohab-LD, para viabilizar o atendimento. A igreja católica se dispôs a comprar os materiais para a construção das unidades provisórias. Quando o projeto de extensão foi contatado para desenvolver o projeto, a sugestão da Cohab-LD era a construção de barracos em madeirite e lona, já que consistiria em um atendimento provisório. Entretanto, foi determinado em audiência de conciliação que os moradores ficarão na "unidade provisória" por até cinco anos. Considerando aspectos de segurança e saneamento básicos, o projeto apresentado pelo grupo extensionista consiste em uma unidade embrião ${ }^{265}$, com parte da construção em alvenaria. No entanto, a Cohab-LD se posicionou contrária à construção das unidades, argumentando que depois - para a retirada das famílias - haverá geração de custo de demolição para a Cohab-LD.

Apesar do andamento das negociações, esse processo tem ocorrido de forma lenta, sempre deixando chegar nos limites das datas de execução da reintegração de posse. A presença da polícia, a apresentação de propostas que nunca contemplavam o número total de moradores, as declarações que criminalizam a ocupação e que colocam os ocupantes como obstáculo para quem aguarda o atendimento na "fila da Cohab-LD" enfraqueceram o movimento da ocupação. Ainda, a proposta de reassentamento, e as condições impostas pela Cohab-LD para que ele se efetive, mostra que ainda está ativo o mesmo modo de operar visto ao longo das décadas anteriores, sustentando o ciclo de precariedade.

\footnotetext{
265 A unidade embrião consiste em uma unidade habitacional entregue com um núcleo principal construído, contendo os cômodos essenciais da casa, que funciona como um embrião para o que será construído posteriormente de acordo com cada demanda de ampliação. Neste caso, as unidades-embrião formarão grupos de casas geminadas com uma base em radier e duas paredes estruturais. A cobertura e a vedação com as respectivas aberturas ficarão sob responsabilidade de cada família.
} 


\section{O Programa de Regularização Fundiária na prática}

O Programa de Regularização Fundiária foi implantado em Londrina, pela primeira vez, na Gestão Barbosa Neto (2009-2012) em 2009, vinculado ao Programa de Regularização Fundiária "Morar Legal" 266 da Cohapar - Companhia de Habitação do Paraná (Governo do Estado do Paraná). Nessa gestão, foram regularizadas mais de 1.200 escrituras $^{267}$. Somente durante a gestão Kireff (2013-2016) foi aberto o setor de regularização fundiária na Cohab-LD que concentrou todos os trabalhos do programa. No entanto, o procedimento não mudou significativamente.

Antes da abertura do Setor de Regularização Fundiária não foi formatado um programa específico com essa finalidade e foram realizadas apenas as entregas dos títulos dos imóveis de bairros que se enquadravam nos critérios do programa estadual, ou seja, bairros consolidados e com infraestrutura. Estes bairros estavam listados no plano de ZEIS que foi retirado de pauta neste mesmo período, portanto a entrega de títulos foi feita sem articulação com outras provisões.

Entre as duas administrações que realizaram o programa de regularização fundiária em questão, há importantes diferenças que merecem ser destacadas.

Barbosa Neto (PDT) é jornalista, proprietário de uma rádio, e ficou conhecido por se tornar apresentador de programas sensacionalistas locais com foco em casos policiais. Perdeu a eleição para prefeito em 2000 para o petista Nedson Micheletti. Em 2002 foi eleito deputado estadual, e em 2006 foi eleito deputado federal.

Em 2008, Barbosa Neto se candidatou pela terceira vez a prefeito, mas ficou de fora do segundo turno, no qual Antônio Belinati foi eleito. No entanto, o segundo turno

\footnotetext{
266 O Programa Morar Legal foi lançado pela Cohapar após a aprovação da Lei Federal no 11.977/2009. Segundo informações da Cohapar, após a entrega dos títulos, as famílias começam a pagar parcelas de 80 reais durante 20 meses. Esse pagamento deve ser revertido para custear outros programas da Companhia. Informações disponíveis em: http://www.cohapar.pr.gov.br/pagina-317.html. Acesso em: 27/10/2019.

${ }^{267}$ Segundo reportagem da Folha de Londrina, foram regularizadas 1.295 escrituras e registros de terrenos entre abril de 2009 e dezembro de 2011. Reportagem disponível em: http://www.londrina.pr.gov.br/index.php?option=com_content\&view=article\&id=14068\%3Agestaobarbosa-neto-regulariza-1295-terrenos-em-londrina\&catid=108\%3Adestaques\&ltemid=288. Acesso em: 26/10/2019.
} 
da eleição foi anulado devido à impugnação da candidatura de Antônio Belinati (que havia sido cassado na administração anterior) que saiu da disputa e, neste cenário, deduz-se que Barbosa neto "herdou" os votos de Belinati e conseguiu se eleger prefeito de Londrina.

$\mathrm{Na}$ sua gestão também adotou uma postura populista, possivelmente por manter a disputa de votos das periferias com a família Belinati. Esta administração ficou marcada por denúncias de corrupção ${ }^{268}$. Barbosa Neto foi cassado antes de completar o último ano do mandato por improbidade administrativa (posteriormente, ele foi absolvido).

A gestão Kireff (2013-2016) se colocou na "nova" vertente do discurso da governança, em oposição ao populismo "tradicional" em Londrina. O prefeito, Alexandre Kireff (PSD), agropecuarista - foi presidente da Sociedade Rural do Paraná entre 2006 e 2010 - e empresário - família foi proprietária da Transportes Coletivos Grande Londrina, empresa responsável pelo serviço do transporte público de Londrina, vendida no final da década de 90 . Segundo descrição do próprio Alexandre Kireff, é empresário dos setores da bioenergia, imobiliário e do agronegócio. Kireff derrotou Marcelo Belinati (sobrinho de Antônio Belinati) no segundo turno das eleições de 2012.

Kireff foi eleito com o discurso de que é empresário e não um político e, por isso, faria uma gestão técnica de viés empresarial ${ }^{269}$. O foco da administração não foi a

\footnotetext{
${ }^{268}$ As denúncias são referentes às Oscips que prestavam serviços na área da saúde, à Guarda Municipal e às licitações de coleta de lixo e da área escolar, e na CMTU - Companhia Municipal de Trânsito e Urbanização. Mais informações sobre os escândalos na administração de Barbosa Neto consultar: https://www.gazetadopovo.com.br/vida-publica/gestao-de-barbosa-neto-foi-polemica-desde-o-inicio35trw1i4lo1f5yggdtynm8fny/; http://g1.globo.com/pr/norte-noroeste/noticia/2016/05/barbosa-netoex-prefeito-de-londrina-e-novamente-denunciado-pelo-mp-pr.html;

https://www.bonde.com.br/bondenews/politica/ex-prefeito-barbosa-neto-e-condenado-porimprobidade-administrativa-412931.html.

${ }^{269}$ Laval e Dardot (2013) vão apontar para a consolidação do governo empresarial. A aproximação do Estado com os conglomerados empresariais se dá tanto com os cargos públicos assumidos por empresários, como com as parcerias público-privado, entre outras formas. No entanto, o conceito apresentado pelos autores diz respeito não apenas às instâncias que diluem a fronteira entre o público e privado. $\mathrm{O}$ que é apresentado corresponde ao modelo de administração das empresas que é transferido para o Estado. O gerenciamento que caracteriza "as regras de funcionamento do mercado competitivo" (Laval e Dardot, 2013, p. 277) é adotado na administração do setor público. O Estado torna-se uma empresa a serviço de outras empresas e será avaliado pela coerência em relação às boas práticas econômicas de governança (Laval e Dardot, 2013).
} 
política habitacional, principalmente porque neste período cessaram-se os recursos federais dos programas habitacionais. Entretanto, procurou fazer uma reestruturação da Cohab-LD durante sua gestão.

Sem dúvidas, após os dados apresentados nos capítulos anteriores, a Cohab-LD foi peça de manobras políticas tanto das gestões Belinati como das gestões petistas, o que acabou criando vínculos entre profissionais de carreira da companhia e os partidos e/ou políticos. O objetivo de desarticular essas estruturas internas resultou em polêmicas aposentadorias compulsórias.

Metas para o "novo" programa de regularização fundiária

Apesar do discurso empresarial e da máscara "técnica" utilizada pela gestão Kireff, a Cohab-LD continuou na ativa e não é possível afirmar que a entrega massiva de títulos de propriedade não foi utilizada como propaganda política, bem como fizeram as gestões anteriores.

A principal diferença talvez esteja na definição do programa que, desta vez, não partiu de interesses em regiões pontuais compatíveis com a concentração do eleitorado. As áreas irregulares foram classificadas como um todo em um sistema de metas norteado pelo "número de títulos a entregar".

Essa mudança é perceptível pela Legislação Municipal. As leis anteriores previam a regularização fundiária em algumas áreas e eram alteradas para acrescentar o novo bairro que deveria ser regularizado. Em 2015, com base nos termos da Lei Federal ํㅡ $11.977 / 2009$, foi elaborada nova lei municipal, que agora tem como foco critérios gerais de gratuidade, sem apontar núcleos específicos.

Se, por um lado, a prática clientelista deixa de ser o critério de escolha das áreas atendidas pelo programa, o olhar generalizante que permite transformar a totalidade das ocupações irregulares de Londrina em dados quantitativos invisibiliza as 
particularidades e abafa as demandas e vulnerabilidades existentes em cada área e transforma o programa de regularização fundiária em um programa de titulação.

Isso mostra a visão do trabalho da Cohab-LD tanto como máquina de fazer votos como de apaziguar conflitos. A entrega de títulos resulta em uma ótima propaganda e transmite a ideia de que "algo está sendo feito" em prol daquelas famílias.

A gestão Kireff dá continuidade, portanto, ao programa de regularização fundiária iniciado na gestão Barbosa Neto, apesar dessas mudanças. A primeira delas foi desvincular o programa das atividades da Cohapar e, portanto, do governo estadual, criando um programa próprio estruturado a partir de dados já existentes em documentos defasados da companhia. A segunda mudança consistiu em reestruturar o setor técnico para abrir um Setor exclusivo para os trabalhos de regularização fundiária. Foi durante essa gestão (2013-2016) que realizei minha incursão no setor, quando a estrutura da Cohab-LD se encontrava conforme mostra o organograma da Figura 16.

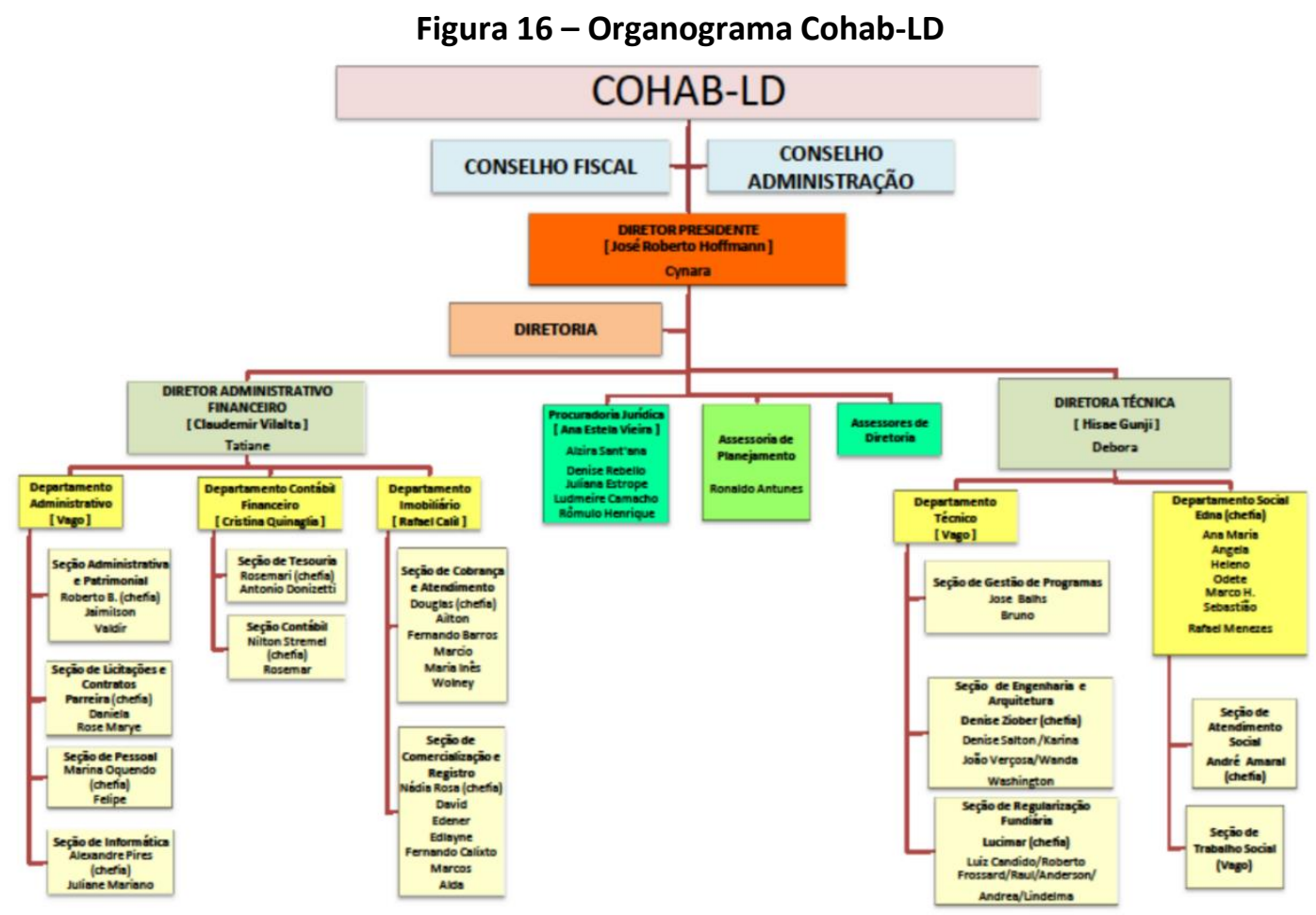

Fonte: Cohab-LD (2016) 
Formada a Seção de Regularização Fundiária no Departamento Técnico, o processo ficou centralizado neste setor, apesar da participação de outros setores continuar sendo necessária em diferentes etapas da regularização fundiária. Quanto a isso, até o ato do registro do parcelamento do solo, os trabalhos ainda não chegaram a essa seção.

A Seção de Regularização Fundiária era formada, naquele momento, por um gestor responsável pelo setor, escolhido para o cargo por ser funcionário da Cohab-LD há mais de 30 anos e, por isso, ter muito conhecimento acerca da documentação dos terrenos da Cohab-LD; uma funcionária do jurídico, que ficou na Seção de Regularização para fazer o atendimento das famílias e coletar e analisar os documentos e, para isso, ela contava com mais duas pessoas; o levantamento da infraestrutura e a análise do projeto em relação à situação atual das ocupações era realizada por um engenheiro; e uma arquiteta recém admitida na Cohab-LD estava começando um trabalho de levantamento e estudo de projetos de unidades residenciais de interesse social para os casos em que, futuramente, houvesse recursos para construção de novas casas nessas áreas.

Na Seção de Regularização Fundiária ficaram concentrados todos os documentos relativos às ocupações irregulares. No processo de abertura do Setor os documentos que estavam dispersos em diferentes setores foram arquivados em caixas e digitalizados formando o banco de dados da nova Seção. Os documentos são relativos aos loteamentos - como projetos, matrículas, certidões, etc. - e das famílias que residiram e/ou residem no local. Como todas as áreas que se pretende enquadrar no programa de regularização fundiária com base na Lei Federal no 11.977/2009 devem ser consolidadas e de baixa renda, foi solicitado ao Departamento Social a elaboração de um histórico de cada área comprovando o tempo de ocupação e a consolidação do bairro, bem como o enquadramento na categoria de regularização fundiária de interesse social, comprovando a baixa renda das famílias.

Identificadas todas as áreas de ocupação irregular enquadradas na categoria de interesse social, elas foram classificadas em três grandes grupos, correspondendo a um "cronograma" do programa de regularização fundiária. O primeiro grupo corresponde 
aos "Núcleos em fase de regularização fundiária", o segundo grupo corresponde aos "Núcleos com possibilidade de regularização fundiária" e o terceiro grupo corresponde aos "Núcleos a serem removidos".

Falemos primeiro das duas categorias de núcleos em que não foram realizados os trabalhos de regularização fundiária por esse programa.

As áreas que foram classificadas considerando a impossibilidade de regularização podem ser divididas em quatro grupos: áreas localizadas em áreas particulares, áreas localizadas em fundos de vale, áreas institucionais ou de domínio da Prefeitura Municipal de Londrina, e áreas da própria Cohab-LD. A relevância de analisar essa classificação deve-se principalmente às incoerências observadas em relação à definição da impossibilidade de realizar a regularização fundiária.

A intervenção em ocupações irregulares de áreas particulares não é atribuição legal da Cohab-LD, para buscar soluções para estes casos existem outros mecanismos legais para que o conflito entre proprietários e ocupantes seja resolvido entre as partes, com ou sem intervenção judicial. Sobre isso, considerando os fatos históricos já mencionados nos capítulos anteriores, a Cohab-LD procurou intervir sempre liberando as áreas com maior valor de mercado. Além disso, a classificação de todas as áreas particulares como núcleos a serem removidos mostra de forma clara a intenção da Cohab-LD de mediar este conflito em favor do proprietário, principalmente considerando que, com exceção da "Invasão ao lado do São Jorge", todas as ocupações ultrapassaram cinco anos e se enquadrariam nos termos da Usucapião Urbana ${ }^{270}$.

É marcante o número de ocupações irregulares situadas em fundos de vale, sendo esta uma característica peculiar de Londrina, como já foi discutido. Nesta listagem que consta nos dados do Programa de Regularização Fundiária não estão contempladas todas as ocupações em áreas de fundo de vale existentes em Londrina. Também é gritante o tempo de permanência da ocupação nestes locais. A ocupação mais antiga data de 1961, outras das décadas de 70 e 80, ou seja, são mais de 50 anos que as famílias

${ }^{270}$ Cabe lembrar que, em 2015, foi dada a reintegração de posse do Morro do Carrapato ao proprietário, mesmo a ocupação datada de 2007. 
residem no local e a solução apresentada ainda é a remoção justificada pelo fato de haver uma área de preservação permanente no local.

Outra incoerência desta classificação diz respeito às áreas que são de domínio da Cohab-LD e estão ocupadas há, pelo menos, 15 anos (considerando a data de produção do documento) e, mesmo assim, foram previstas as remoções das famílias destes locais.

Tabela 5 - Núcleos a serem removidos

\begin{tabular}{|c|c|c|c|}
\hline Núcleos a serem removidos & Ano da Ocupação & № Famílias & Região \\
\hline \multicolumn{4}{|c|}{ Localizados em Área Particular } \\
\hline Favela Colosso & 1975 & 80 & OESTE \\
\hline Rua Cecílio de Oliveira & 1991 & 15 & SUL \\
\hline Vila Feliz & 2001 & 46 & SUL \\
\hline Morro do Carrapato & 2007 & 66 & LESTE \\
\hline Invasão ao Lado do São Jorge & 2014 & 248 & NORTE \\
\hline \multicolumn{4}{|c|}{ Localizados em Fundo de Vale } \\
\hline Fundo do Jardim Paulista (Cantinho do Céu) & 1961 & 7 & NORTE \\
\hline Fundo de Vale do Sérgio Antônio & 1973 & 36 & LESTE \\
\hline Fundo de vale da Rua Zircônio & 1975 & 5 & LESTE \\
\hline Fundo de Vale da AV. Santa Mônica & 1985 & 26 & LESTE \\
\hline Fundo de Vale do Jardim Santa Mônica & 1989 & 20 & NORTE \\
\hline Fundo de Vale da Rua Café Arábica & 1989 & 6 & NORTE \\
\hline Fundo de Vale do Jardim Paraíso- Rua Patativa & 1989 & 16 & NORTE \\
\hline Fundo do Alto da Boa Vista I & 1993 & 7 & NORTE \\
\hline Fundo de Vale da Rua Renato Fabrete & 1993 & 10 & OESTE \\
\hline Fundo de vale do Santa Fé - Horta & 1994 & 33 & LESTE \\
\hline Fundo de Vale Marizia II & 1995 & 33 & CENTRO \\
\hline Fundo de Vale da Rua Stä. Mônica & 1996 & 4 & LESTE \\
\hline Fundo de Vale do Jardim Monte Cristo & 1996 & 45 & LESTE \\
\hline Fundo de Vale Mangaba/Rosa Branca & 1996 & 29 & LESTE \\
\hline Fundo de Vale Jardim Bananeiras & 1996 & 2 & LESTE \\
\hline Fundo de Vale Newman Sayun & s/info & 1 & SUL \\
\hline Fundo de Vale- Jardim Cristal & 1997 & 18 & SUL \\
\hline Fundo de Vale do JD. Quadra Norte & 1999 & 2 & NORTE \\
\hline Fundo de Vale do Marieta & 2002 & 68 & NORTE \\
\hline Fundo de Vale do Córrego Sem Dúvidas & 2014 & 180 & NORTE \\
\hline \multicolumn{4}{|c|}{ Localizados em Terrenos da PML } \\
\hline União da Vitória II- Área Verde & 1985 & 33 & SUL \\
\hline Vila Ricardo - Terreno escola & 1992 & 12 & LESTE \\
\hline Esq. Av. Theodoro Victorelli/Rua Cajá/A. Rosa Branca & 1992 & 4 & LESTE \\
\hline Pinheiros/Jd. Alto da Boa Vista II & 1993 & 1 & NORTE \\
\hline Centro Comunitário Santa Fé & 1994 & 20 & LESTE \\
\hline Rua do Latão & 1994 & 16 & LESTE \\
\hline C.H. Cafezal 2 e 3 & 1994 & 23 & SUL \\
\hline Fundo do Jardim Santa Inês - Rua Pingo D`Água & 1996 & 26 & LESTE \\
\hline Heron Domingues & 1996 & 21 & LESTE \\
\hline Viela Santa. Mônica & 1996 & 10 & LESTE \\
\hline Praça Jardim União da Vitória II & 1998 & 54 & SUL \\
\hline \multicolumn{4}{|c|}{ Localizados em Terrenos da Cohab-LD } \\
\hline Triângulo Santa Inês - "Jd Santa Mônica" & 1985 & 39 & LESTE \\
\hline Jardim União da Vitória V (Rua dos médicos) & 1985 & 70 & SUL \\
\hline Cilo III & 1990 & 29 & OESTE \\
\hline Jardim União da Vitória VI (Rua dos Olheiros) & 1998 & 330 & SUL \\
\hline Total & & 1293 & \\
\hline
\end{tabular}

Fonte: Cohab-LD (2016).

Grande parte dessas áreas foi alvo de remoções para o Conjunto Residencial Vista Bela, conforme discutido no capítulo anterior. Elas também estavam previstas no 
Plano de Remoções Involuntárias financiado pelo BID, o que não foi realizado até agora. Entre a época em que foi realizada esta listagem e o presente momento, as ocupações irregulares cresceram progressivamente, tanto em novas áreas como pelo adensamento em áreas já ocupadas.

O segundo grupo de núcleos que não foram - ainda - incluídos no programa de regularização fundiária corresponde aos núcleos que foram considerados aptos para serem regularizados, porém ainda há algum tipo de barreira para sua efetivação. Esses núcleos podem ser divididos em três grupos: loteamento com casas que foi desenvolvido pela Cohab-LD, assentamento que foi desenvolvido pela Cohab-LD, e ocupações irregulares consolidadas.

O primeiro caso é o da Vila Marizia II que começou como um loteamento com a construção de algumas casas realizados pela Cohab-LD. Porém, parte deste parcelamento foi ocupado de forma irregular posteriormente e ocorreu a subdivisão dos lotes existentes, resultando em um parcelamento que não corresponde ao projeto original. Além disso, uma porção de área pública também foi ocupada e parte do bairro não possui infraestrutura básica e será necessária a implantação das redes de água e esgoto, drenagem e pavimentação das vias. Por isso, foi necessária a desafetação da área pública para a Cohab-LD - já realizada - e a contratação do levantamento topográfico, sondagem e projeto de urbanização da área. Como não houve nenhum tipo de injeção de recursos neste programa, a prefeitura e a Cohab-LD não viabilizaram a urbanização e, por isso, o processo de regularização não foi para frente.

O segundo caso, de um assentamento realizado pela Cohab-LD na década de 1970, corresponde a um setor do Jardim Leste-Oeste. Esta área não apresenta problemas em relação à infraestrutura, que já foi implantada. A barreira para a regularização fundiária de um setor do Jardim Leste-Oeste é consequência da disputa em torno da desapropriação da área que é propriedade particular. O proprietário do terreno é o Jockey Club de Londrina, mas não tinha conhecimento da propriedade até ser notificado para a regularização fundiária. Ao ter conhecimento, passou a reivindicar a desapropriação da área pelo poder público. O caso foi para a justiça que decidiu a favor 
da Cohab-LD. Esse trâmite levou à paralização da regularização fundiária dessa porção do Jardim Leste-Oeste, ainda em negociação junto ao Cartório de Registro de Imóveis.

As demais áreas são correspondentes a ocupações irregulares em áreas públicas e particulares. Todos os casos, nove no total, dependem da elaboração de projetos urbanísticos para implantação de infraestrutura. Como não há recursos, os processos não foram encaminhados, já que na época não seriam titulados sem a infraestrutura mínima. Hoje, com a vigência da Lei Federal no 13.465/2017, isso se tornou possível apesar dos riscos evidentes. No presente momento (2019) o atual prefeito Marcelo Belinati optou por dar andamento na regularização fundiária da Vila Marizia II e no Jardim Rosa Branca, sob os termos da Lei n⒔465/2017. Grande parte dos casos que não entraram no programa de regularização ainda estão parados na etapa de contratação do levantamento topográfico do local. Além da falta de infraestrutura, alguns núcleos encontram-se sob domínio da Prefeitura e dependem de desafetação para a Cohab-LD para viabilizar a regularização fundiária. Observa-se pela tabela a seguir que apenas o Jardim Leste-Oeste e o Jardim Rosa Branca estão com a aprovação do loteamento confirmada.

Tabela 6 - Núcleos aptos a serem regularizados

\begin{tabular}{|c|c|c|c|c|c|c|}
\hline \multirow[b]{2}{*}{$\begin{array}{l}\text { Núcleos Habitacionais aptos à } \\
\text { regularização fundiária }\end{array}$} & \multicolumn{3}{|c|}{ Origem do Núcleo Habitacional } & \multirow[b]{2}{*}{$\begin{array}{l}\text { Aprovação } \\
\text { do Projeto }\end{array}$} & \multirow[b]{2}{*}{$\begin{array}{c}\text { Total } \\
\text { de } \\
\text { Lotes }\end{array}$} & \multirow[b]{2}{*}{ Domínio } \\
\hline & $\begin{array}{c}\text { Loteament } \\
\text { o e Casas } \\
\text { COHAB-LD }\end{array}$ & $\begin{array}{c}\text { Loteament } \\
\circ \\
\text { COHAB-LD }\end{array}$ & $\begin{array}{l}\text { Ocupação } \\
\text { Irregular }\end{array}$ & & & \\
\hline Jardim Leste Oeste - Setor 2 & & $x$ & & $\begin{array}{c}02 / 06 / 201 \\
4\end{array}$ & 29 & $\mathrm{COHAB}$ \\
\hline Jardim Rosa Branca & & & $x$ & $\begin{array}{c}12 / 04 / 201 \\
6\end{array}$ & 137 & $\begin{array}{l}\text { COHAB/ } \\
\text { PML }\end{array}$ \\
\hline $\begin{array}{l}\text { Áreas remanescentes Jardim Morar Melhor - } \\
\text { Quadra 3, PML e Praça } 3\end{array}$ & & & $x$ & & 21 & $\begin{array}{l}\text { COHAB/ } \\
\text { PML }\end{array}$ \\
\hline Vila Amaral & & & $x$ & & 18 & $\mathrm{COHAB}$ \\
\hline $\begin{array}{l}\text { Remanescente Jardim Santa Luzia (parte da } \\
\text { área) }\end{array}$ & & & $x$ & & 13 & $\mathrm{COHAB}$ \\
\hline Remanescente Alto da Boa Vista I & & & $x$ & & 45 & $\mathrm{COHAB}$ \\
\hline Shekinah & & & $x$ & & 92 & $\mathrm{COHAB}$ \\
\hline Jardim São Rafael & & & $x$ & & 106 & $\mathrm{COHAB}$ \\
\hline Quadra 10, Área PML do Jardim Cristal & & & $x$ & & 24 & $\begin{array}{l}\text { COHAB/ } \\
\text { PML }\end{array}$ \\
\hline Jardim Monte Cristo - Praça 3 & & & $x$ & & 12 & PML \\
\hline Vila Marizia II & $x$ & & & & 68 & $\begin{array}{l}\text { COHAB/ } \\
\text { PML }\end{array}$ \\
\hline $\begin{array}{l}\text { Remanescente do C. H. Vivi Xavier e } \\
\text { Quadras } 25,26 \text { e } 27\end{array}$ & & & $x$ & & 79 & PML \\
\hline \multicolumn{5}{|c|}{ Total } & \multicolumn{2}{|c|}{644} \\
\hline
\end{tabular}

Fonte: Cohab-LD (2016). 
O Jardim Leste-Oeste, o Jardim Morar Melhor e o Jardim Monte Cristo foram regularizados no programa, ficando apenas parte da área a espera da implantação da infraestrutura ou a espera de soluções quanto ao domínio da área.

Entretanto, mesmo identificadas e classificadas como áreas aptas a serem regularizadas, com algumas parcialmente em fase de regularização, a Cohab-LD havia realizado a mobilização das famílias para serem removidas para o Residencial Vista Bela e Residencial Cristal também nessas áreas, com o argumento de que poderia reduzir o adensamento para facilitar a regularização fundiária.

Principalmente no Jd. Shekinah e no Jd. São Rafael (zona leste), os próprios documentos da Cohab-LD mostram que os moradores apresentaram resistência em sair do local e estavam organizados e representados por lideranças comunitárias. Nessas áreas, os moradores têm maior clareza sobre as possibilidades de regularização da situação do local e, por isso, não aceitaram a remoção para o Residencial Vista Bela. No Shekinah, das 87 famílias residentes no local, apenas 8 aceitaram sair.

No Jd. São Rafael também houve resistência por parte dos moradores que se recusaram a sair durante a mobilização da Cohab-LD. No relatório da visita a intenção de promover a remoção é clara com base no argumento de que o Jd. São Rafael está localizado em área de preservação ambiental. Pelas informações do relatório observamos que na primeira visita não conseguiram mobilizar os moradores para sair e voltaram com a orientação de informar os moradores da impossibilidade de regularizar a área pelos motivos descritos. No entanto, no levantamento da área contratado pela Cohab-LD, fica claro que as casas não invadem os 30m de APP referente ao córrego que limita a ocupação, apenas nove casas foram construídas na APP no raio de $50 \mathrm{~m}$ referente à preservação da nascente. 
Figura 17 - Localização do Jd. São Rafael próxima ao Fundo de Vale

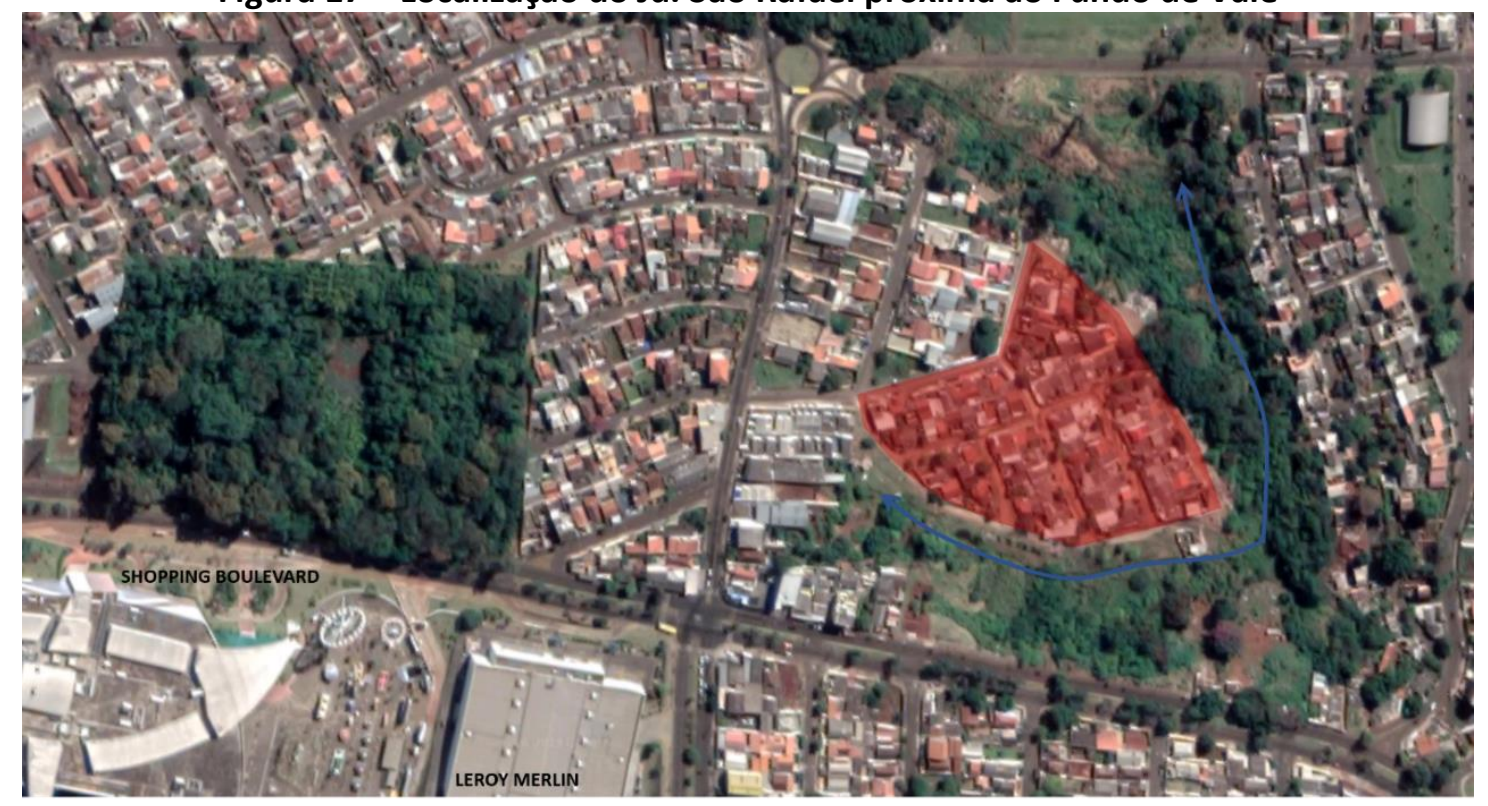

Fonte: Google Earth, adaptado pela autora.

Novamente, o que se observa é o discurso ambiental utilizado como pressuposto para promoção da remoção da favela. Neste caso, o Jd. São Rafael está localizado na zona leste de Londrina, a poucas quadras do Complexo Marco Zero, comentado no capítulo anterior. Portanto, o Jd. São Rafael fazia parte dos núcleos a serem removidos da zona leste, retirados das imediações dos novos empreendimentos que fazem parte da reestruturação econômica da área, para o Res. Vista Bela. Porém, a organização e a resistência dos moradores inviabilizaram a remoção e o núcleo foi enquadrado como apto à regularização fundiária, apesar do argumento da Cohab-LD quanto aos limites ambientais.

Núcleos regularizados no Programa de Regularização Fundiária

Neste tópico apresento os núcleos regularizados no Programa de Regularização Fundiária de Londrina, bem como os meandros dos procedimentos burocráticos que caracterizam o conceito de regularização fundiária neste programa. Para fazer isso, começo pela história do Jd. São Marcos, um dos núcleos regularizados, para mostrar que esse programa corresponde a apenas uma etapa do que se compreende por 
"Regularização Fundiária Plena". Para apresentar aqui, o histórico foi recuperado por entrevistas com moradores da área, os documentos do Jd. São Marcos coletados durante o levantamento da Cohab-LD e reportagens sobre o bairro.

\section{Jd. São Marcos: mais de 20 anos na luta pela regularização}

Chegando para a entrevista ${ }^{271}$, Jurandir ${ }^{272}$ perguntou se poderíamos nos sentar no ponto de ônibus mesmo, já que não existe nenhum outro mobiliário urbano no bairro. Ele disse que prefere assim, pois outros assentos poderiam atrair a "molecada". Começamos a conversa com a história de como começou a ocupação que deu origem ao Jardim São Marcos.

Jurandir contou que na época da ocupação 273 (há aproximadamente vinte anos), ele estava desempregado e sem condições de pagar aluguel.

Na hora de comprar terreno apareceram as dificuldades da vida que as pessoas pedem tanta coisa que a gente viu que não tinha condições de comprar um terreno. Nessa época que eu vi que tinham muita gente invadindo terreno. E conversando com um deles, ele me deu uma ideia: 'lá perto da onde você mora tem tanto que o pessoal usa para jogar lixo, cachorro morto, cavalo morto. Então por que você não pega aqueles terrenos lá e chama um grupo de pessoas e luta para poder transformar num bairro?' E eu voltei para casa pensando nisso.

A outra pessoa está falando de terrenos vazios no Jardim Perobal, próximo ao Conjunto Habitacional São Lourenço. Jurandir disse que pensava que o terreno era da Cohab-LD por estar envolto por conjuntos habitacionais. O terreno está vazio até hoje e é de propriedade de uma loteadora.

Mas então veio o problema: como começar? Então eu peguei um caderno e peguei o nome de quinze famílias. Quinze pessoas que

\footnotetext{
${ }^{271}$ Entrevistas concedidas à autora e a Natália Tamanaka em 07/07/2017 e em 15/11/2017. Transcrição realizada por Tamanaka (2017).

272 Nome fictício adotado para preservar a identidade do entrevistado.

273 Segundo o histórico reconstruído pelo Setor Social da Cohab-LD, a ocupação ocorreu na década de 1990.
} 
estavam naquela mesma situação pagando aluguel com dificuldades em tudo. E toparam, mas na hora de fazer mesmo entraram apenas três famílias porque os outros ficaram com medo e não quiseram mais.

Quando começaram a levar as coisas para o terreno que seria ocupado, a CohabLD foi ao local e afirmou que eles teriam que sair na tentativa de inibir a ocupação e evitar a vinda de mais famílias para o local.

Então, entramos nós três, três barraquinhas, tem até foto da época. $\mathrm{E}$ uma pessoa chegou na gente e falou que não adiantava a gente investir, não adianta vocês fazerem isso que nós vamos ter que tirar vocês daí. E então nós pegamos lona, pegamos tábua velha, e mais materiais e transformávamos em parede.

Eles continuaram o processo de ocupação, se instalaram em barracos bastante precários, e logo a imprensa divulgou o fato o que trouxe visibilidade e atraiu moradores de cidades próximas e distritos que residem até hoje no Jd. São Marcos.

Nesse momento, Jurandir relatou que já tinham a preocupação de se organizar de uma forma que facilitasse a regularização posteriormente, liberando espaço para infraestrutura, mesmo com funcionários da prefeitura dizendo que não seria possível a regularização naquele local.

E a gente foi separando os lotes, terrenos. Que a minha preocupação no começo era a organização. Era não deixar, se caso acontecesse, daquele local ali, viesse a ser legalizado, já estava organizado para isso. Não tem a dificuldade, de até a prefeitura muitas vezes chegar aqui e falar que não tem como fazer rua aqui porque não dá. Não tem como fazer uma fossa, rede de esgoto.

Para Jurandir, a presença de casas fez diminuir o acúmulo de lixo que existia no terreno. É comum em Londrina que terrenos vagos e áreas livres como os fundos de vale se tornem pontos de descarte de lixo, principalmente resíduos de construção. Nesse mesmo dia Jurandir nos levou ao terreno da antiga ocupação e verificamos que o terreno continua vazio com montanhas de lixo e resíduos da construção civil. Jurandir 
se mostra indignado com a postura do poder público em priorizar a desocupação e deixar o terreno sem manutenção e acúmulo de lixo, comprometendo a qualidade da vizinhança.

E então o que aconteceu? A gente vendo aqueles terrenos que eram usados para lixo e foi surgindo tudo, os barraquinhos, até acabou com os lixos dali da região, acabou com tudo. Não jogam mais animais mortos por ali. Nos outros terrenos se você for ver por lá, a montanha de lixo que as pessoas jogam, cavalo, cachorro, tem até fogo, fumaça tóxica né, contaminando todo mundo. E eu acredito que se tivesse acontecido de ficar lá aquele local teria resolvido um grande problema que tem por ali do lixo e tudo quanto é situação que tem por ali.

Logo após a ocupação do terreno, foi concedida a Reintegração de Posse ao proprietário (uma loteadora) e, por isso, tiveram que dar início às negociações com a Cohab-LD para encontrar uma alternativa para onde ir. Segundo documentos da CohabLD, após a concessão da reintegração, a Companhia foi "informada e orientada a comparecer no local juntamente com a polícia militar e cães, ambulâncias, dentre outros".

Durante o período em que acompanhei os trabalhos da Cohab-LD, nas visitas a campo algumas vezes são identificadas novas ocupações, que são registradas por fotografias e depois encaminhadas para o setor técnico organizar visita ao local e fazer o levantamento dos ocupantes.

Alguns casos de reintegração de posse ainda são acompanhados por profissionais da Cohab-LD que ficam encarregados de mediar a desocupação e evitar que se desenrolem conflitos entre a polícia e os ocupantes. Outros dois casos relatados a mim tiveram atos de resistência e uso de força policial.

E aconteceu naquela época de, não sei, o juiz ou um promotor público que decretou reintegração de posse. E então decidiram que teria que tirar nós junto da COHAB (sic). Então a gente não sabia para onde ir, que não tinha para onde ir. $E$ eu andando junto com alguns colegas, $e$ nessa altura a gente já estava com 151 famílias. Formamos um grupo de pessoas que a própria COHAB chamou para discutir com eles como 
melhor organizar, mas como a reintegração de posse havia saído, gerou um problema social maior ainda. Para onde iria todo mundo?

Foi que eu lembrei que havia outro terreno próximo desse primeiro, que junto desse grupo de pessoas, viemos analisar como que era esse novo terreno. E nele havia um problema muito grande na rede de esgoto, que sempre que estourava os canos vazava por todo ele as fezes. Então isso aqui ficava tudo lavado dessas coisas mesmo que esgoto tem, de fossa.

Nos documentos da Cohab-LD relatam que no primeiro momento, as famílias foram remanejadas para um campo de futebol nas proximidades até o poder público definir um espaço para realocá-las. Segundos os relatos de uma funcionária da CohabLD contidos nos documentos, era um dia de muita chuva em que os trabalhos começaram de madrugada e se estenderam até a noite do dia seguinte. A Cohab-LD forneceu alimentos e lonas (cortadas de $4 \mathrm{~m}$ em $4 \mathrm{~m}$ ) "para que as famílias construíssem seus barracos provisórios".

Ainda segundo os documentos da Cohab-LD, as famílias sabiam que a Cohab-LD era proprietária de um terreno na região274, e reivindicaram o reassentamento nessa área. Segundo Jurandir, a Cohab-LD argumentou que a área era imprópria para moradia por ser alagadiça e, por isso, não tinha a intenção de leva-los para lá. Ainda na tentativa de negociar o terreno, os moradores verificaram que o terreno não era alagadiço, mas que havia uma parte da tubulação de esgoto arrebentada naquela área. Assim, a CohabLD realizou o levantamento no local e, após confirmar a informação, decidiu trazer as famílias para o terreno275 após os reparos. Nesse momento, havia 151 famílias no local. Na chegada ao terreno do Jd. São Marcos, Sr. Jurandir contou que ele teve que exigir da

274 Esse conhecimento pode estar associado ao que me foi relatado por um dos funcionários da CohabLd de que na gestão da Cohab-Ld nesse período, o André Vargas (PT) 274 "vazou" a informação de onde se localizavam os terrenos da Cohab-Ld para movimentos que articulavam ocupações em Londrina. Nessa gestão, correspondente à gestão municipal de Luiz Eduardo Cheida (PT, na época), André Vargas (PT) estava em uma diretoria da Cohab-Ld em que o presidente da Companhia era Nedson Micheletti (PT). Posteriormente, André Vargas foi eleito vereador e Nedson Micheletti prefeito. André Vargas foi preso pelos crimes de corrupção passiva e lavagem de dinheiro na operação Lava-Jato em abril de 2015. 275 De acordo com os documentos da Cohab-LD, o terreno cedido era apenas uma parte da área de propriedade da Companhia. 
Cohab-LD a demarcação dos lotes e das ruas. A Cohab-LD abriu apenas três ruas "muito estreitas".

Depois disso a $\mathrm{COHAB}$ começou a levantar a área e decidiram transferir a gente para onde estamos. Mas antes que eles terminassem de arrumar aqui, venceu a data de reintegração de posse e queriam tirar a gente de lá. Como não tinha como colocar a gente aqui porque na época eu estava pedindo esse tipo de organização, que eu queria vir de uma vez, então que eles viessem e fizessem a demarcação lote por lote tudo certinho. Então a COHAB veio junto da prefeitura e começaram a abrir as ruas, levantamento topográfico, e decidiram onde seriam os terrenos e as ruas.

O próximo problema foi com a água e luz. De início, em parceria com a Sanepar, foi colocado um cavalete comunitário. Então todo mundo ia buscar água nesse cavalete. $\mathrm{E}$ as ruas ficaram muito estreitas. Foi pedido para que eles alargassem as ruas. Se deixasse do jeito que eles estavam fazendo seria inviável um carro subir e o outro descer na mesma rua. Então hoje as ruas estão mais largas, e é tudo barraco, tudo barraquinho mesmo, porque era o jeito de se socorrer as famílias, em baixo de lona.

Figura 18 - Assentamento das famílias no atual terreno do Jd. São Marcos

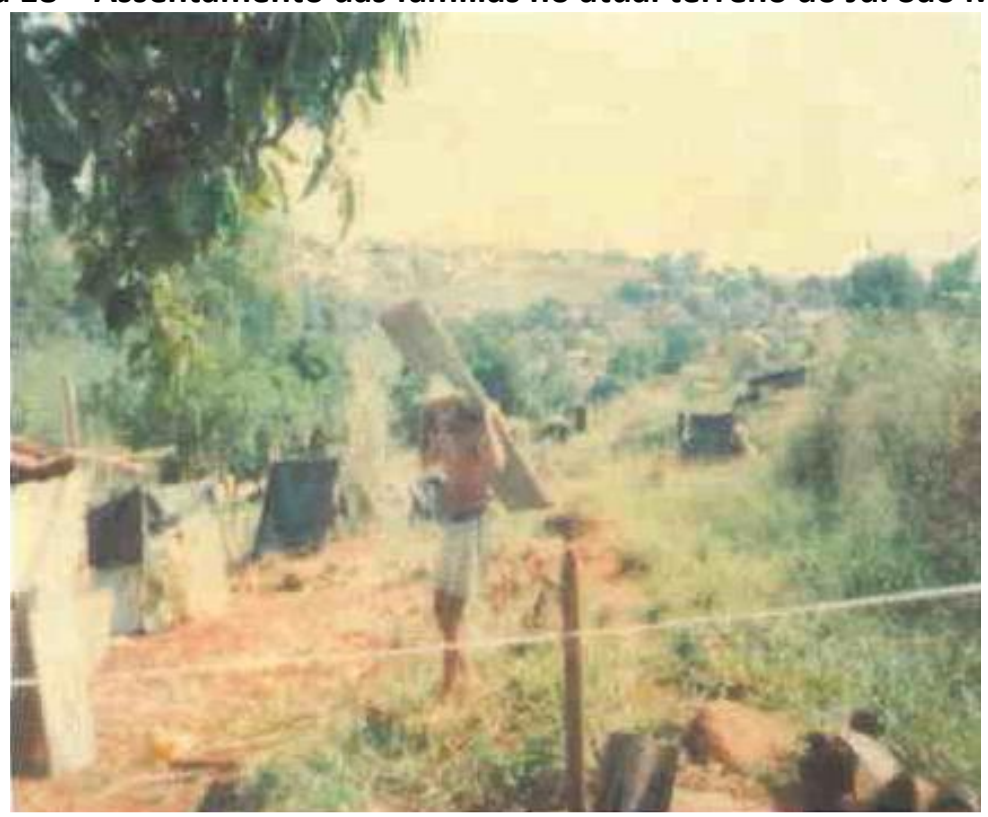

Fonte: Cohab-LD (2016)

A partir desse momento essa ocupação passou de "invasão" para a categoria de "Assentamento". Na terminologia utilizada pela Cohab-LD, após a remoção das famílias 
para o terreno, o núcleo deixa de ser considerado "invasão" e passa a ser de responsabilidade do município, sendo chamado de "assentamento". Esta é a principal forma de diferenciação entre as ocupações espontâneas e os assentamentos promovidos pela Cohab-LD, já que fisicamente são muito semelhantes. Apesar de ambos corresponderem a situação irregular de ocupação, a palavra "invasão" remete a um crime, enquanto assentamento remete a uma situação emergencial. Esse sentido das palavras é reproduzido nos documentos oficiais, nos discursos oficiais e nos diálogos informais e também na mídia. Em uma de suas formas, a prática do reassentamento é utilizada após a reintegração da posse de áreas ocupadas (como foi o caso do Jd. São Marcos, e é o caso da ocupação Flores do Campo).

De acordo com os documentos da Cohab-LD, o terreno foi parcelado em 160 lotes e os moradores foram construindo "abrigos improvisados" ou barracos nessa área de declividade acentuada.

Então a gente se tornou assentamento. E quando se torna assentamento já cai a responsabilidade da própria prefeitura de estar organizando também. Quando é invasão é por conta da gente, quando é assentamento eles têm já que oferecer coisas melhores para a gente. Isso também ajudou muito, se tornar assentamento. Em seguida a gente continuou na ideia de lutar para regularizar. E foi a maior dificuldade, porque havia vereador a favor, vereador contra achando que a gente não tinha que ficar aqui, então a gente debatia: como que aqui não dá sendo que no União da Vitória é um bairro com mais declividade nas ruas e foi montado esse bairro gigante por lá, e aqui que é bem menos declive, mais plano, não vai poder fazer um bairro? E aí foi nessa luta.

O terreno apresenta uma caída de $50 \mathrm{~m}$ em direção ao fundo de vale, em um trecho de $260 \mathrm{~m}$, resultando em uma declividade de aproximadamente $20 \%$. A implantação das quadras no sentido norte-sul intensifica o efeito da declividade por locar as ruas no sentido da maior declividade, perpendiculares às curvas de nível. As calçadas são estreitas, onde praticamente não cabem árvores. Por isso, há poucas áreas sombreadas e as pessoas caminham na rua. Observamos uma mulher grávida e uma senhora idosa subindo a rua sob sol forte em direção ao bairro vizinho. 
Quando foram reassentados na área do atual Jd. São Marcos, portanto, a CohabLD havia demarcado onde seriam as ruas e os lotes. As famílias se instalaram em moradias precárias construídas com materiais improvisados, lona cedida pela Cohab-LD, restos de materiais de construção, etc.

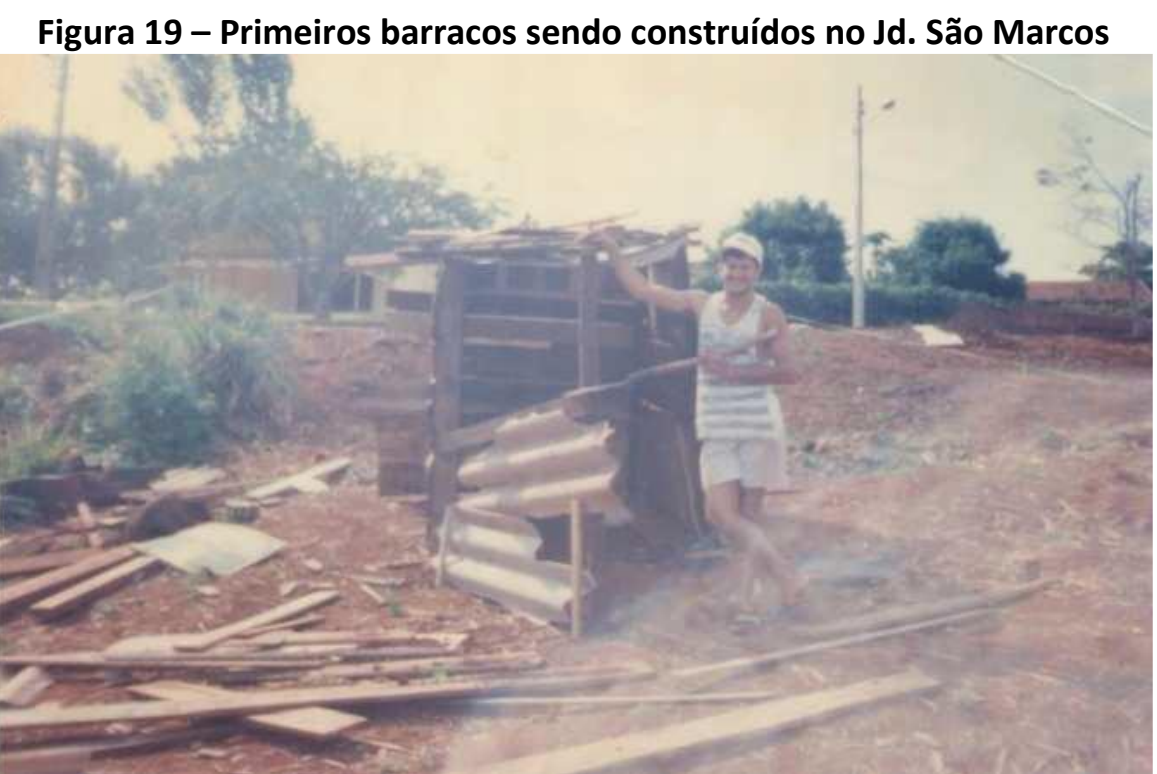

Fonte: Cohab-LD (2016)

Hoje, a condição física das casas é diversa. Na maior parte delas os traços da autoconstrução são evidentes, porém algumas parecem ter sido reformadas recentemente, com diferentes níveis de acabamento de piso, revestimentos e telhado. Algumas casas não possuem acabamento, as telhas são reaproveitadas e as condições de precariedade são mais claras. A implantação das unidades não segue um padrão e não parece corresponder às exigências da legislação urbanística. 
Figura 20 - Residências Jd. São Marcos

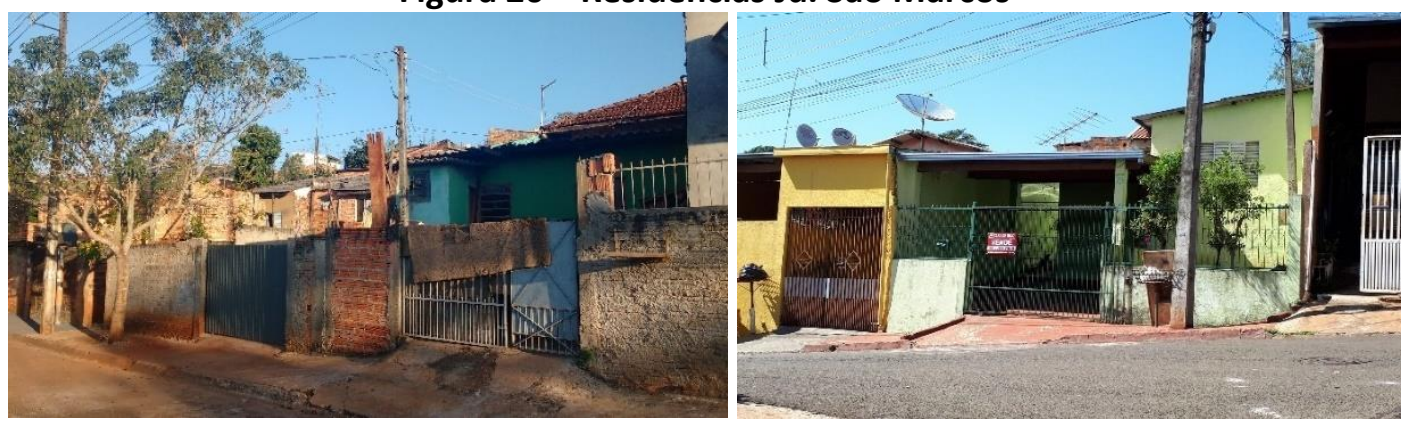

Fonte: da autora (2017)

Figura 21 - Residências Jd. São Marcos

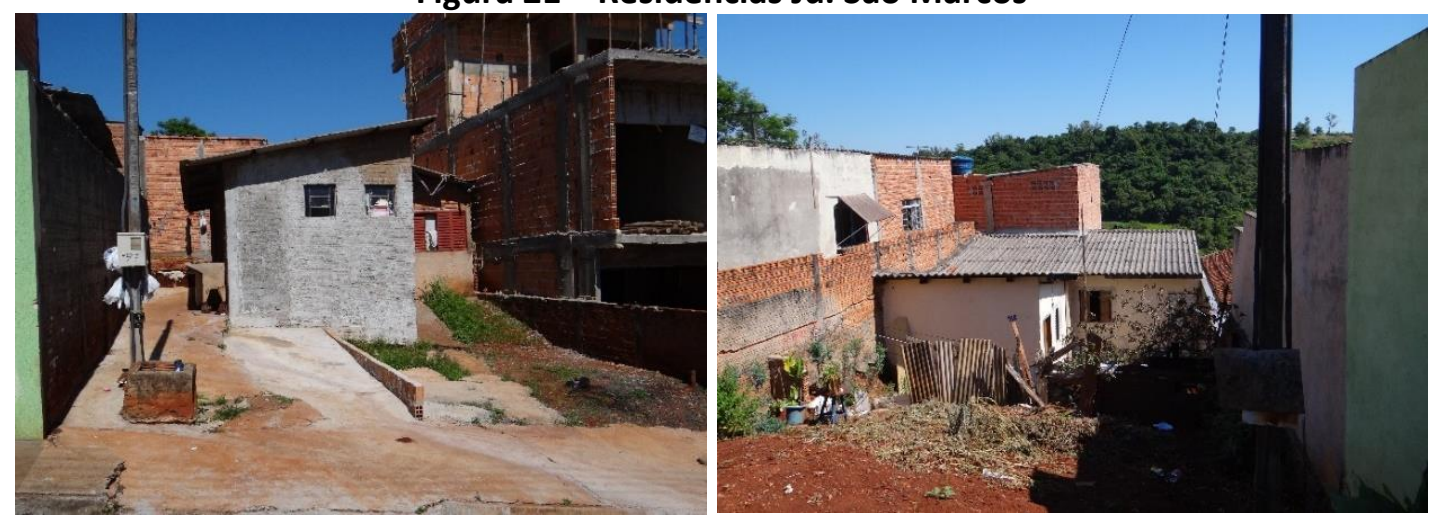

Fonte: da autora (2017)

Parte desse processo da autoconstrução ${ }^{276}$ das casas do Jd. São Marcos é descrita pelo Jurandir, e ele fala que as famílias melhoraram as condições após a instalação no bairro seguindo ritmos diferentes. Ele cita redes de apoio que algumas famílias tiveram, e a estrutura que a própria comunidade proporcionou.

Na questão de melhorias das casas tinha pessoas que já melhoraram as condições. Elas trabalhavam e muitas vezes o patrão fez algum acerto com a pessoa por estar cinco ou seis anos trabalhando com a pessoa, e ela já comprou o material. E assim foi. Então tudo baseado nessa forma. Alguns conseguiram um emprego melhor, outros o pai e a mãe deram uma ajuda e comprou o material parcelado. $E$ foram surgindo as casas. Mas a gente notou que algumas pessoas foram

\footnotetext{
${ }^{276}$ Importante detalhar as características da autoconstrução local, caracterizá-la como um processo que tem etapas/fases (podemos analisar em que fase a regularização fundiária está atuando): no começo, materiais mais improvisados, restos de materiais de construção, vedação com tapumes e partes de móveis, estrutura frágil feita com madeira, cobertura com telhas remendadas, etc. Depois, tijolos e estrutura em concreto. Os acabamentos correspondem à última etapa (móveis também vêm antes).
} 
ficando para trás. Foi que eu comecei a ir atrás de pessoas que pudessem arrumar material de construção, um doava um saco de cimento outro doava um caminhão de areia, outro doava cal, outro tijolo.

A Sercomte ${ }^{277}$ mesmo teve um trabalho fundamental aqui, em que os funcionários de lá, não sei que tipo de acordo eles fazem que eles têm um benefício, e este benefício eles doam. E quando eu fiquei sabendo desse projeto eu fui atrás deles para que pudessem ajudar a gente. Então foram construídas várias casas aqui dessa forma. Depois tivemos aqui um empresário da cidade, que eu estive participando de um programa de televisão, que eu fui convidado, que sempre que eu precisasse o canal da TV estaria aberto lá para eu me manifestar. E então no dia, o repórter fazendo as perguntas para mim, no que saiu no ar o empresário viu a reportagem e quis se oferecer também para ajudar. Com isso foram feitas três casas aqui. E assim vem vindo, e as pessoas ajudam como podem também. Cada dia melhorando mais e fazendo as casas.

No outro dia, Jurandir contou que o empresário que ajudou na construção de três casas, estava disposto a construir mais. Porém, a dificuldade de articular mais moradores para contribuir no mutirão das construções foi muito grande, portanto, as casas foram construídas apenas para os que participaram do mutirão.

E mais tarde trocou o prefeito, na época entrou o prefeito Nedson Micheleti que deu uma ajuda muito grande, o deputado André Vargas. A própria Cohab. Esse pessoal deu uma ajuda muito grande para gente com essa parte da documentação, e também orientar a gente o que pode e o que não pode conseguir com a documentação.

Para a construção da infraestrutura foi necessária, novamente, a articulação dos moradores. Como foi falado, na fase de reassentamento a Sanepar instalou um cavalete comunitário de onde todos os moradores tiravam a água e por muitos anos eles ficaram sem energia elétrica.

Rede elétrica também foi no começo. Assim que foi reconhecido como assentamento, na reunião que teve lá a gente já foi vendo do que precisava. Era o cavalete de água e pedimos já a luz. Mas o primeiro

${ }^{277}$ Empresa Municipal de telecomunicações. 
que veio foi a água, o cavalete no caso. Depois veio a luz. Que a gente ficou sem luz um tempão, e foi que a gente começou a brigar que veio o projeto de iluminação.

Em 2007 duas reportagens da Folha de Londrina ${ }^{278}$ mostram manifestação dos moradores solicitando implantação da rede de esgoto. Na descrição do bairro, as ruas são de "terra batida". Naquele momento as obras estavam paradas há dois meses, pois a empreiteira se recusou a terminar a obra pelo valor que estava previsto no contrato. Além das obras incompletas, os moradores enfrentavam o problema dos vazamentos das fossas domiciliares.

A luta do Jurandir e dos moradores do Jd. São Marcos, pontual, mas articulada, é responsável por mobilizar o poder público e as empresas concessionárias a providenciar a infraestrutura. Jurandir conta vinculando essas ações a uma ideia de conquista decorrente da sua luta e dos outros moradores, o que é de fato. Mas isso também mostra que, mesmo classificado na categoria de assentamento, o bairro não foi atendido de imediato pelo poder público com obras de urbanização.

Na sua fala rápida quase se perde o peso de uma rotina marcada por tantas lutas e dificuldades no contexto do bairro. Ele conta em meio a outros comentários que, cada vez que aumentava a intensidade das $\operatorname{chuvas}^{279}$, ele e outros moradores precisavam socorrer algumas casas. Ele apontou para uma casa na esquina de baixo da praça. Esse lote se encontra em um ponto de desnível, em que a rua está quase no mesmo nível que o ponto mais alto do muro, enquanto a casa foi construída na cota de baixo. Por estar na esquina e, portanto, na bifurcação das duas ruas a água que escorre com velocidade alta na rua entra no lote, e não desvia para a rua lateral. A ausência do asfalto, das bocas de lobo e de galerias para conduzir a água faz com que ela desça seguindo a declividade e procurando as linhas de drenagem. Jurandir contou que de baixo de chuva ele e outros moradores ajudavam a tirar a lama com baldes para não alagar a casa.

\footnotetext{
278 Fonte das reportagens: https://www.folhadelondrina.com.br/cidades/empresa-abandona-obra-nosao-marcos-613086.html e https://www.folhadelondrina.com.br/cidades/moradores-do-sao-marcosprotestam-na-prefeitura-620524.html. Acesso em 27/10/2019.

${ }^{279} \mathrm{~A}$ incidência de chuvas em Londrina é alta, mas em alguns meses do ano a intensidade aumenta e são frequentes as notícias de situações de emergência em áreas mais precárias da cidade.
} 
Figura 22 - Residência vulnerável a alagamentos localizada abaixo do nível da rua

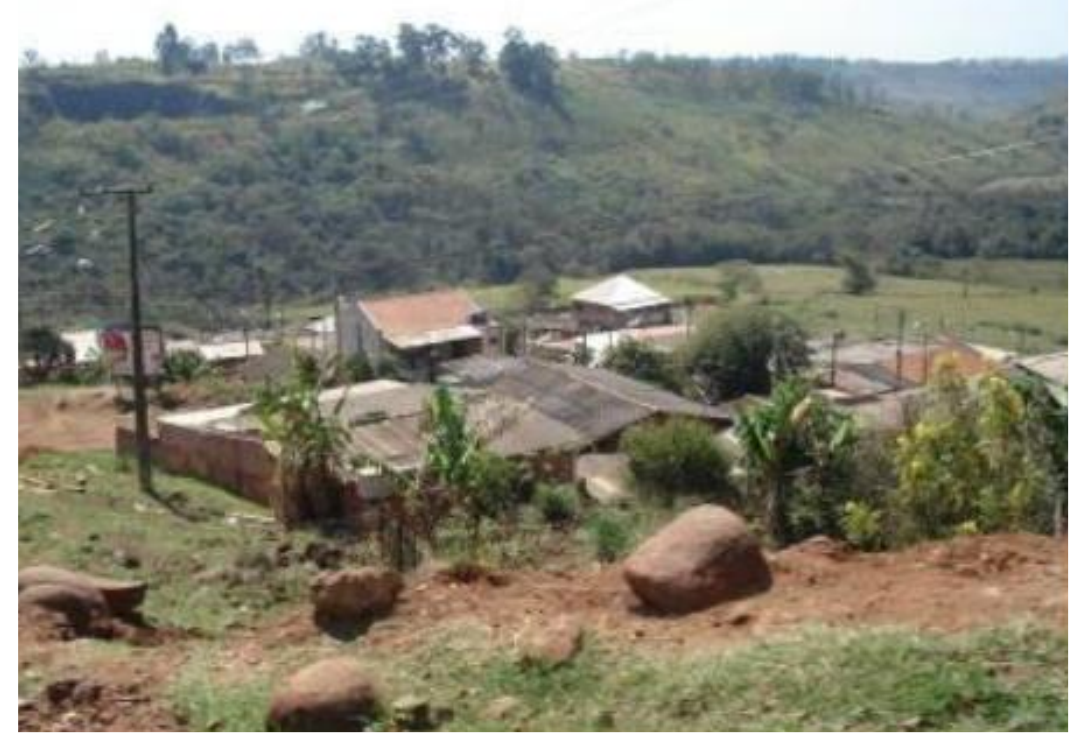

Fonte: Cohab (2016).

A falta de infraestrutura, por tornar tão difícil o dia a dia do bairro, também influenciou na permanência dos moradores no bairro.

Teve esse ponto que a gente considera negativo. Porque a gente lutou por todo mundo na época, a gente estava lutando por todo mundo, achando que todo mundo pegaria a casa e ficar, então tem uma grande parte das pessoas que saíram. Venderam a casa. Tem aqueles que melhoraram de vida né, e conseguiram comprar um terreno em outro lugar. Isso aí é normal. A gente vê como um lado positivo. Mas tem aqueles que venderam aqui e voltaram a pagar o aluguel. A gente até dava conselho para pessoa pensar sobre voltar a pagar o aluguel que não compensava, até o dia que conseguisse comprar um terreno fora daqui e fazer uma casinha, mas as pessoas pensavam "não estou gostando porque é muita subida, o asfalto não vem logo". Porque a desistência era bem na época da dificuldade mesmo. Que era muito barro não havia asfalto. Então foi nessa época que muitas pessoas acabaram saindo. Depois, se acomodaram um pouco. Eu notei que com o asfalto feito as pessoas começaram a permanecer. Mesmo assim a gente queria que todos ficassem, a gente lutou junto né.

Aos poucos a situação do bairro, em termos de infraestrutura, vai sendo regularizada com a implantação do mínimo necessário. Entretanto, com a urbanização, são cobradas as taxas correspondentes. Isso também tem um impacto, principalmente 
para quem está em situação irregular há algum tempo. Jurandir fala em tom de crítica às pessoas que não querem pagar as taxas, pois demonstra conhecimento a respeito da relação entre a arrecadação municipal e investimentos.

Depende do ponto de vista de cada um. Porque tem pessoas que criticaram. Agora tem que pagar imposto. Igual quando eu estava lutando lá: o asfalto veio de fundo perdido, beleza, não teve custo. Quando eu consegui transformar as fossas que tinham aqui, que além de mau cheiro tem barata, ratos, pernilongos, um monte de insetos. Quando eu consegui brigar lá com a Sanepar em Curitiba, todo mundo reclamava que tinha fossa dentro de casa, e quando eu consegui a rede de esgoto, que foi feita a rede de esgoto... aí que começaram a chegar os talões de água cobrando a rede de esgoto, o pessoal começou a ficar bravo. Mas são críticas que a gente já esperava que teria. São pessoas que querem os benefícios, mas não querem o custo. Querem tudo de graça. Eu nunca pensei assim, eu pensei que para melhorar tem que pagar os impostos. Que é através dos impostos que o prefeito gera as coisas que vem atender a comunidade. E o dinheiro não cai do céu para o prefeito trabalhar nas cidades. Depois veio a questão da documentação da regularização que vem para gente, que eles não gostaram porque tinham que começar a pagar o IPTU. Não todos né. Mas a grande parte apoia. Acham que está caro, porque eles comparam o bairro nosso aqui com o São Lourenço, por exemplo. Tem casa no São Lourenço, uma casona mesmo, que paga hoje uns trezentos reais de IPTU, e a gente aqui está pagando quatrocentos, quinhentos. Então tem esse lado que as pessoas me cobram muito para a gente ir em cima da COHAB rever essa situação.

Quando perguntei se as pessoas têm a iniciativa de comercializar a casa após a regularização, ele respondeu que não. Ele afirmou que teve mais procura por terrenos, mas que mesmo quem põe à venda ainda não tem a intenção de vender. Mas é possível interpretar que com o aumento da procura após a regularização o preço dos terrenos pode valorizar.

Não, depois que colocou o asfalto eu não tive notícias. E nem com a regularização. E assim, depois da regularização a gente viu pessoas querendo vir para cá, tem sempre pessoas procurando casas para vender. Até tem plaquinhas de vende-se a casa, mas quando você vai ver ele está só especulando para subir o preço. 
Com relação ao espaço público, como comentado, o asfalto está em boas condições. Porém as calçadas são estreitas e a falta de arborização é notável, sobretudo pelo fato de as pessoas subirem as ruas muito inclinadas ao sol. Jurandir contou que tentou realizar uma ação para promover a arborização do bairro, mas não deu certo.

A praça é só essa aqui, mas não está muito certa. Porque tem a praça, mas a gente não quer o banco. E no projeto de praça eles querem por banco. A gente quer a praça, revitalizar ela, inclusive eu fiz um projeto aqui na época, com as crianças, para plantar árvore. Que na época eu consegui 116 mudas de árvores. Importante falar essa história aqui na árvore, para vocês verem como é a dificuldade de ser presidente de bairro. Tem aquela coisa de plantar as árvores para ficar bonito o bairro e também que sobe o morro no sol quente pegando na cabeça não tem uma árvore para fazer a sombra. $\mathrm{E}$ a gente queria envolver as crianças no projeto para falar para elas a importância de se ter uma árvore, conversamos com os pais delas. Todo mundo achou legal. No dia que chegaram as mudas para a gente plantar, eu chamei 116 crianças porque cada uma iria plantar uma. Vieram onze crianças apenas. E algumas sem pai. Como que faria para cavar buraco? Eu iria cavar sozinho? Porque eu chamei os pais, mas ninguém foi. Então eu cancelei o projeto, e mudei a data de plantar, depois eu falei que cada árvore receberia o nome daquela criança, que ela seria a responsável por cuidar da árvore, e tudo o mais. Quando a árvore estivesse grande a gente tiraria foto com a criança, com a mudinha também. $E$ isso seria legal. Mas não ligaram muito para essa ideia não. E ninguém foi novamente. Depois eu marquei outra data dizendo que teria sanduíche e refrigerante. Aí veio gente até de fora. Gente que não mora aqui para ajudar a plantar árvore. Teve mais gente que árvore. Mas foi gostoso, ter um projeto, mas tem que oferecer alguma coisa porque parece que só plantar árvore não incentiva as pessoas, não vale nada. Não dá valor nenhum, mas se tiver um lanchinho, então tudo bem. E você começa a analisar a cabeça de cada um. É muito do ser humano.

Observamos que o bairro possui espaços coletivos apesar de falta de equipamentos e mobiliário urbano. Esses espaços são a praça, localizada em um terreno íngreme logo na entrada do bairro e a capela, construída pelos moradores e que também exerce a função de associação de bairro. 
Figura 23 - Praça do Jd. São Marcos

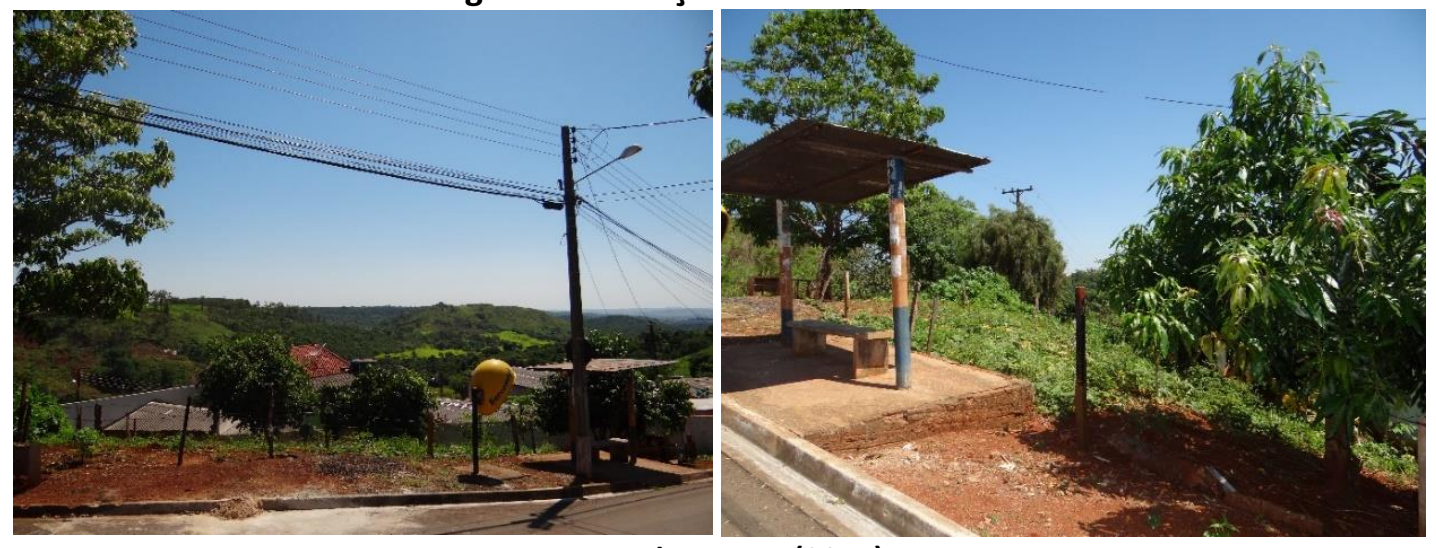

Fonte: da autora (2017).

Ainda na entrada do bairro há uma edificação autoconstruída, sem acabamento, em formato de barracão, que funciona como um centro comunitário para reuniões comunitárias, confraternizações e atividades vinculadas à igreja católica.

Depois disso a gente construiu essa capela aqui perto, na mesma situação, mas com um investimento maior da Igreja do São Lourenço, igreja católica. E a mão de obra sempre foi nossa, mesmo. Então eu como presidente de bairro eu pegava sábado, domingo, feriado, junto de um morador aqui vizinho meu. Nós ficávamos aqui o dia inteiro batendo massa, subindo tijolo, nós que erguemos e está aí hoje o resultado.

Figura 24 - Capela do Jd. São Marcos

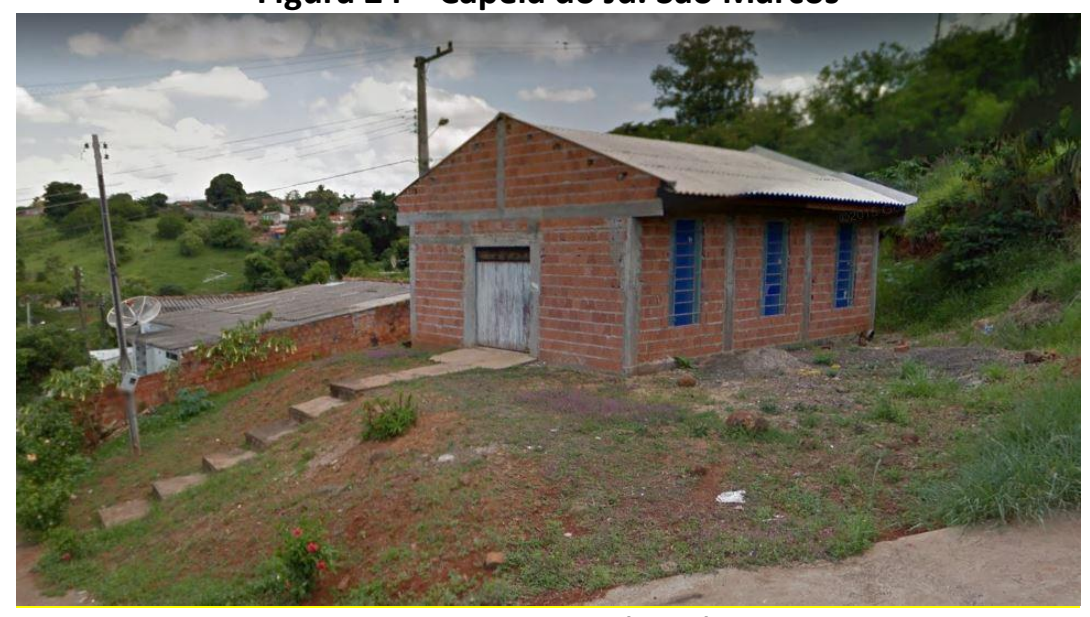

Fonte: da autora (2017). 
Em frente à praça encontra-se a horta comunitária, implantada em 2010. Apesar da estrutura, encontra-se abandonada. Segundo Jurandir, a moradora que cuidava da horta faleceu recentemente. A entrega da horta foi divulgada pela prefeitura ${ }^{280}$ como parte de um projeto de construção de hortas comunitárias em vários bairros da periferia durante a gestão Barbosa Neto.

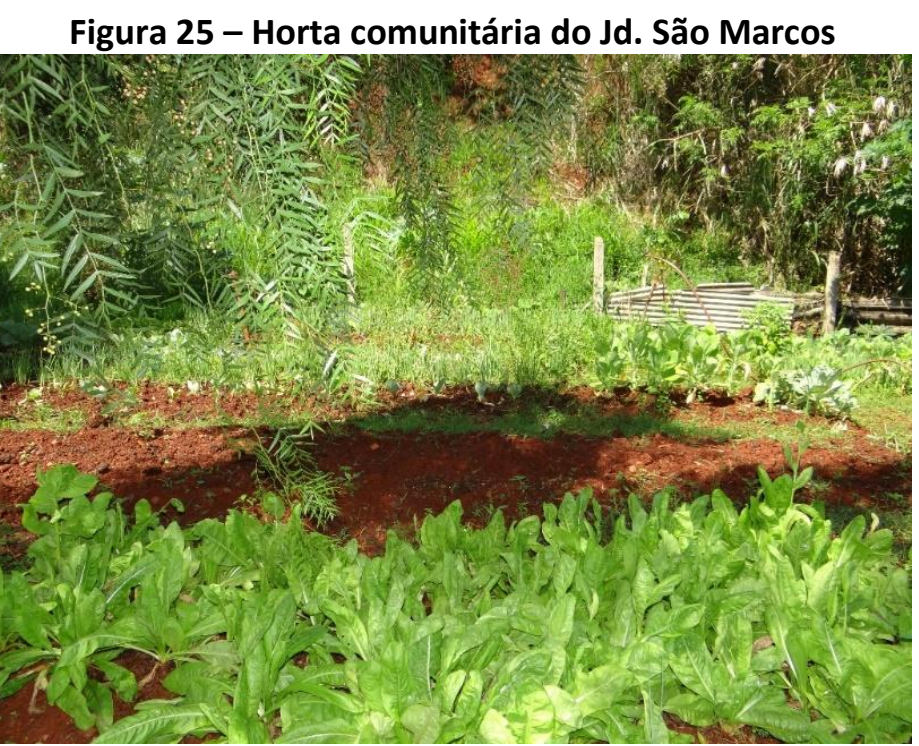

Fonte: Letícia Cabrera (2017).

Na cota mais baixa do terreno, em direção ao fundo de vale, há um campo de futebol. O acesso para o campo é difícil devido à declividade e ausência de um acesso planejado. O campo está bem abaixo da cota da rua que passa em frente e dá acesso a ele.

Segundo Jurandir essa área era ainda mais baixa e o acesso era quase impossível. Ele estava negociando com a prefeitura nesse período para aterrar parte dessa área para possibilitar o uso para lazer pelos moradores. Depois de um período de negociações o prefeito da época (Cheida-PT) providenciou a terra e os tratores para aterrar. As obras começaram, mas foram embargadas pela Promotora de Justiça do Meio Ambiente na

\footnotetext{
${ }^{280}$ A matéria completa pode ser vista em: http://www.londrina.pr.gov.br/index.php?option=com_content\&view=article\&id=15333\%3Alondrinaganha-a-42o-horta-comunitaria-no-jardim-sao-marcos\&catid=108\%3Adestaques\&ltemid=288
} 
época ${ }^{281}$, pois a obra avançava nos 60 metros de área de preservação permanente correspondente à faixa sanitária e mata ciliar. Por isso, o aterro foi apenas parcial, elevou um pouco o nível de onde foi improvisado um campinho de futebol.

Hoje os moradores utilizam o campo, mas Jurandir nos disse que o fato de não ter alambrado e pelo aterro não ter sido completo coloca as crianças em uma situação de risco, pois a bola cai no fundo de vale com frequência e as crianças vão buscar. Como a praça é pequena e encontra-se em um terreno íngreme e sem mobiliário urbano, o campinho pode ser considerado a principal área de lazer do bairro.

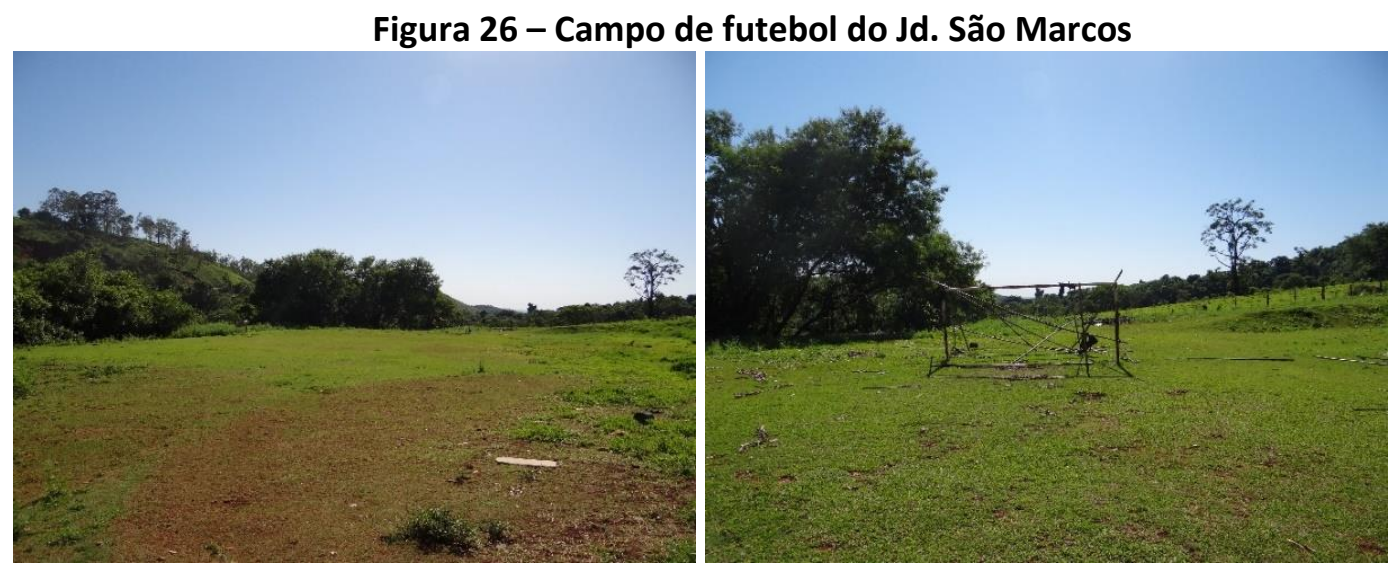

Fonte: Letícia Cabrera (2017).

${ }^{281}$ A Promotora era a mesma do caso comentado anteriormente sobre o Morro do Carrapato. 
Figura 27 - Desnível do campo de futebol em relação ao nível da rua, devido ao aterro parcial

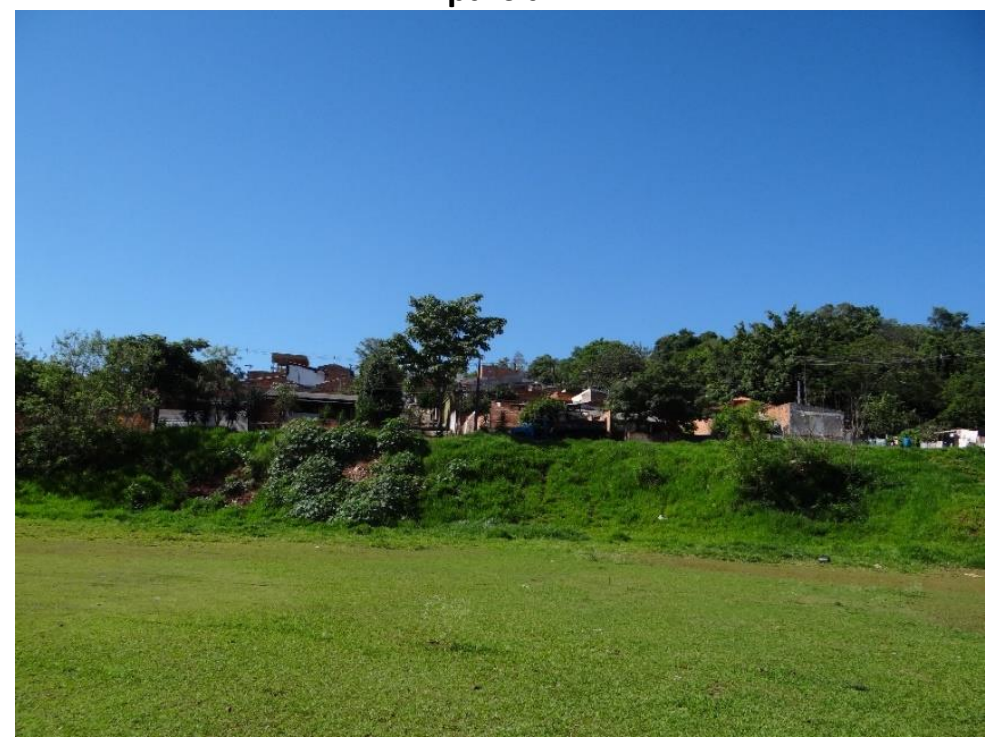

Fonte: Letícia Cabrera (2017).

Descendo a primeira rua avistamos alguns barracos enfileirados em toda a lateral do bairro. A ocupação parece ser recente, e algumas casas estão sendo construídas em alvenaria pelos moradores. Como é recorrente na periferia, no fim de semana os moradores constroem e reformam as casas. Quando perguntamos ao Jurandir sobre essa porção do bairro recentemente ocupada ele fez questão de reforçar que não sabe como começou, e que não teve nenhuma participação na organização da ocupação. (A preocupação deve ser pelo fato de agora estar ligado à política.)

Então, essa ocupação começou e eu não estava nem aqui. Teve uma época que eu fiquei fora do São Marcos, fiquei quase um ano morando em Porecatú, e deixei minha filha morando aqui. Lá a gente ficou sabendo que haviam invadido aqui o São Marcos, e depois quando eu voltei que eu vi os barraquinhos ali. Então eu não acompanhei muito. E não tem como a gente ficar ajudando eles no sentido de incentivar a invasão, não porque a gente acha que estamos bem agora e eles que deixa para lá. Mas é porque eu já tive um problema uma vez, de ajudar na iniciativa e justiça ficar em cima de achar que eu estou organizando, incentivando. Eles chegam a falar: "olha a gente está pensando em fazer tal e tal coisa", eu respondo "vocês fazem o que vocês devem fazer, e faz vocês". Porque eu não dou nem conselho, se chega no ouvido de alguém que eu dei conselho, falei alguma coisa, pode me dar problema. 


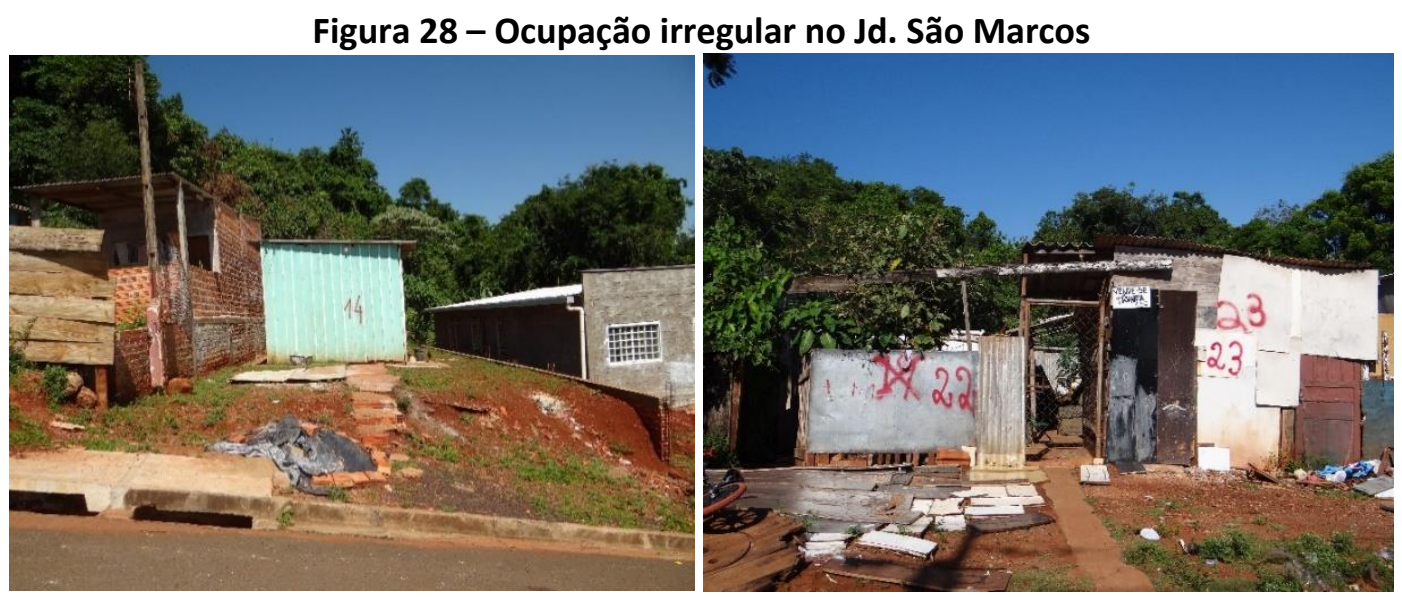

Fonte: Letícia Cabrera (2017).

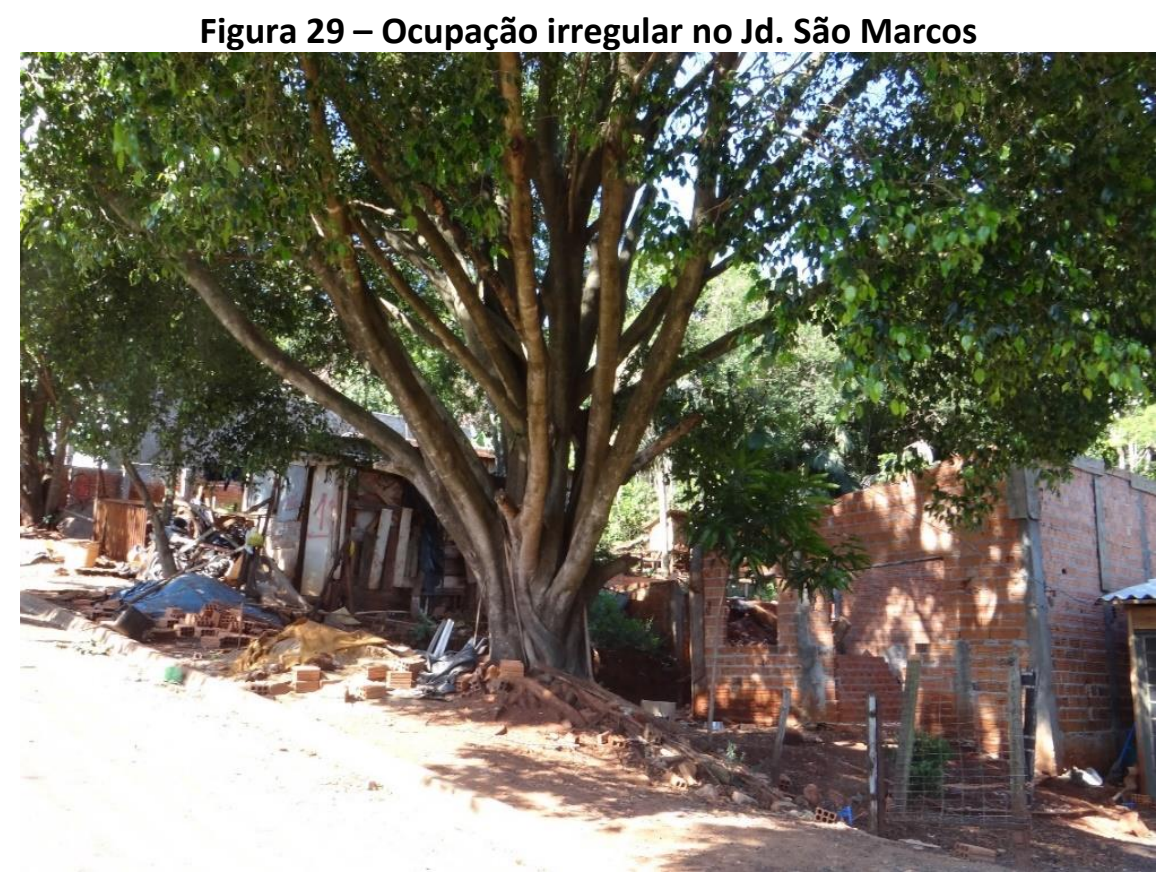

Fonte: Letícia Cabrera (2017).

Jurandir nos disse que conhece algumas pessoas da ocupação e indicou uma moradora, caso quiséssemos mais informações sobre os moradores da ocupação. Apresentou-nos para Vanessa ${ }^{282}$, dizendo que ela é filha de uma antiga moradora do São Marcos e que é participativa no bairro, que estava procurando emprego e ele a tem ajudado como pode.

\footnotetext{
282 Nome fictício utilizado para preservar a identidade da entrevistada.
} 
A maioria de quem está ali eu conheço. São pessoas que eram daqui da região mesmo, uns são filhos de pais que moram aqui mesmo. Que cresceram, casaram e estão ali. Porque se você for ver é importante mesmo acontecer aquilo ali.

Vanessa estava com seu filho de dois anos no colo, andando rápido e perguntou se gostaríamos de ver sua casa. Contou-nos que seu marido estava construindo, mas como eles dois estão desempregados, enfrentam dificuldades para comprar os materiais para construir a casa. Em frente à casa chamou a atenção a condição precária da construção, feita com restos de materiais de construção e móveis velhos. Vanessa relatou que seu marido esteve preso e saiu recentemente e tem encontrado dificuldades para conseguir emprego. Ela, como teve o filho recentemente, também ficou fora do mercado de trabalho e agora está com dificuldades para voltar.

Ela nos contou que sempre morou com sua mãe no bairro até se casar. Depois se mudou para o Jd. Califórnia e, em seguida, para o Perobal (os dois bairros na região sudeste, mesma região do Jd. São Marcos). Por não conseguir mais pagar aluguel, e com o filho pequeno, voltou para a casa da sua mãe neste bairro. Depois que seu marido saiu da reclusão eles ficaram em casas separadas e, recentemente, decidiram ocupar um dos terrenos já que o pai de seu marido também estava construindo uma casa nesta ocupação.

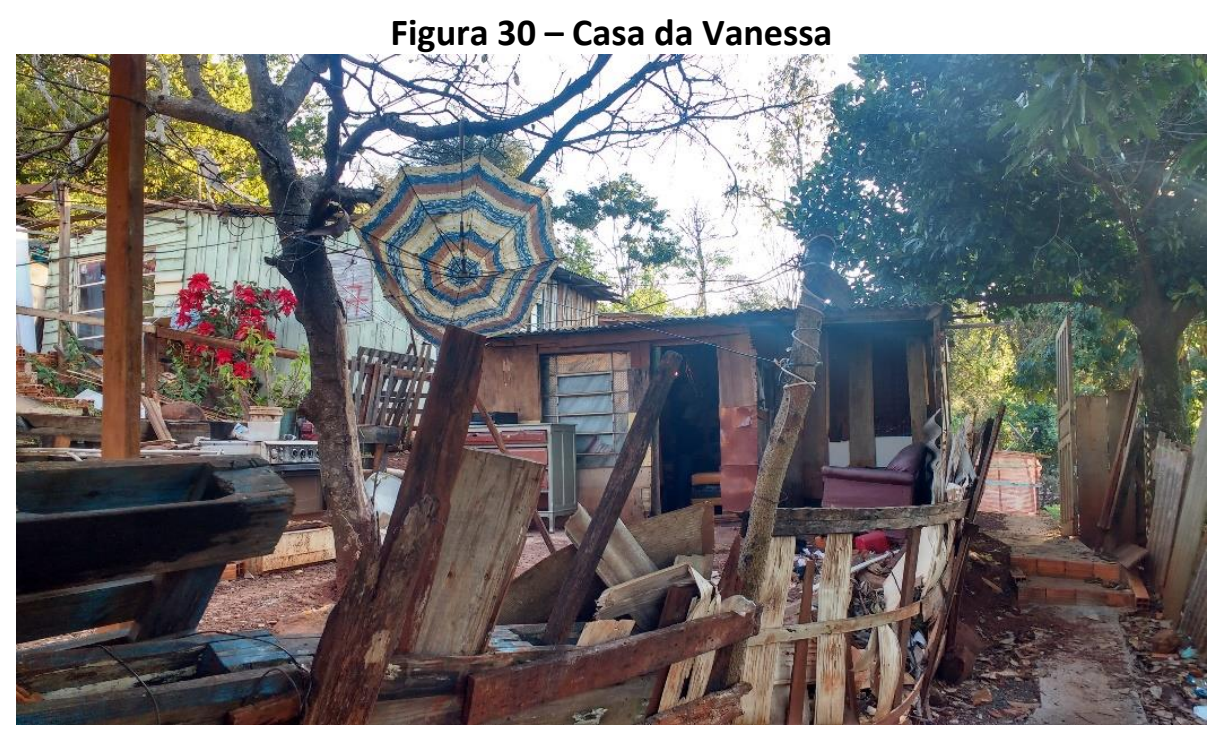

Fonte: Natália Tamanaka (2017). 
A Vanessa revelou que a maior parte dos ocupantes desta porção do Jd. São Marcos é composta por filhos dos moradores antigos, e que cresceram no bairro. O filho do Jurandir também é um dos ocupantes. Isso se repete em grande parte das ocupações irregulares. A esse fato recorrente, algumas funcionárias do Setor Social da Cohab-LD chamaram de "filhos da ocupação".

A contagem e numeração das casas é o primeiro passo (às vezes o único) da Cohab-LD no diagnóstico da ocupação. Observamos que algumas casas apresentam um acabamento de maior qualidade, o que não se vê com frequência nas ocupações mais precárias. Vanessa disse que algumas pessoas acreditam que ali será facilmente regularizado, por estarem de frente para a rua. Ela comentou que sua irmã está morando no barraco atrás do dela e que disseram que ali seria mais difícil de regularizar, por estar próximo da área de preservação. Observamos que alguns barracos foram construídos formando uma nova fileira de casas sem acesso direto para a rua.

Os terrenos aparentemente foram divididos com frentes iguais. No fundo não há delimitação, mas pelo mapa é possível ver que há um córrego no fundo dos terrenos, estabelecendo um limite. Alguns terrenos estão cercados, com pequenos recuos entre as casas.

E na época eu não tinha pretensão política nenhuma também. E hoje o pessoal fica pegando no meu pé "sai candidato a vereador rapaz", que na época a imprensa era muito em cima de mim, tudo eles vinham falar comigo. Se eu desse um toque no celular de alguém, já chovia repórter. Eu parecia o presidente de Brasil. E nisso muita gente me queria dentro da política. E eu nunca quis.

Caminhando pelo bairro no domingo, observamos grupos de jovens sentados na calçada e uma menina andando de bicicleta nos observando. Conversamos olhando em direção ao fundo de vale. Jurandir aponta para um bairro do outro lado do fundo de vale, que se encontra em área irregular, onde as pessoas compraram o terreno e que não é possível regularizar. 
Geralmente é um grupo de pessoas que acontece assim: de repente você esteja numa situação que assim, casa, está ganhando super bem, pagando aluguel e do nada é mandado embora. E começa a atrasar tudo. Não consegue arrumar outro emprego. O cara vai te despejar, você vai para onde? É nesse momento que se você tiver coragem você enfrenta a causa. Ou você vai morar onde? Em baixo da ponte? Ou pegar um terreno da prefeitura, ou morar na casa dos pais, se os pais tiverem condições de te ajudar. E se não tem também? Então assim, você se vê numa situação. Muita gente é contra, eu tive muitas pessoas na época que me criticavam um monte, mas eu falava "você está me criticando porque você não está passando por este momento", eu falava. Falei isso para policial, para sargento, falei para o próprio prefeito. Esse terreno aqui era usado por um boi, cavalo que o cara colocava aqui, no meio do esgoto mesmo. E além disso, na época, se a gente for analisar tudo, como era o terreno aqui? Com rede de esgoto a céu aberto, contaminando lençol freático, o rio que passa ali em baixo, com um mal cheiro a tarde aqui que era insuportável, na hora do almoço que o vento tocava para lá, mas a noite a mesma coisa. Hoje, depois que surgiu o bairro, a maravilha que está. Ao mesmo tempo, de uma invasão de terra se tornou um benefício social.

Então se você for analisar pontos, teve um monte de ponto positivo, não tem negatividade aqui. Você fala: "mas aqui é fundo de vale". Que fundo de vale? Fundo de vale é lá em baixo. Tinha essa conversa também que aqui seria fundo de vale. Fundo de vale eu também sou contra, desmatar para fazer, está cometendo um crime não é mesmo? Não é só questão da lei, é questão de natureza, do ambiente. Tem que ter consciência né. E na questão da invasão que a gente estava comentando, teve uma conversa de liberar uma parte, outros falam para não liberar nada, mas tem uma conversa de um trecho para liberar. Pelo o que eles falavam para mim antigamente eu acho que eles não liberam nada dali. Pelo fato de ser muito próximo às árvores, próximo de barrancos, aqui você já vê a diferença. É descida, mas é mais suave que ali. Então eu não sei qual que é a ideia da COHAB para atender o pessoal dali, que eu espero que seja uma ideia boa, porque ali há muita gente que necessita mesmo de ajuda de casa.

As casas mais antigas do bairro são maiores, a grande maioria é de alvenaria, com outras sem acabamento. É possível ver uma evolução: os barracos mais precários feitos com restos de materiais de construção, tapumes e partes de móveis, partes de telhas sobrepostas, alguns pilares improvisados de madeira dão a sustentação. Por dentro, as únicas divisórias são para o banheiro. O encanamento e os fios de energia estão todos aparentes. De tamanho parecido, mas com um nível de acabamento um 
pouco melhor, existem as casas de tábuas e mata-junta e telhado de apenas uma água, piso bruto e a casa construída direto no chão. Outras casas ainda bem pequenas, apenas de tijolos ou com pilares e vigas em concreto e fechamento em tijolos, sem acabamento, e telhado de uma água. As casas mais antigas são maiores, ocupam porções maiores de terreno (que também são maiores). Algumas tem reboco e são pintadas.

Considerando que o conceito de regularização fundiária plena consiste no conjunto de ações de urbanização, organização da comunidade, etc, é possível afirmar que isso ocorreu no Jd. São Marcos em um período de 20 anos, tendo como único impulso a pressão exercida pelos moradores sobre o poder público por meio de manifestações e divulgação para a mídia.

A ocupação começou em uma área particular de uma loteadora e a Cohab-LD interveio promovendo um assentamento urbano em um terreno da companhia. Prática recorrente em gestões anteriores, como visto, mas aqui ficam evidentes os termos do conflito fundiário. Neste caso, a ocupação como ato de resistência e como ato de necessidade.

Pela fala, observamos como o cotidiano fica condicionado a aguardar a próxima atitude do poder público que ora parece apoiar, ora desmobilizar. Ao mesmo tempo, a importância de uma liderança comunitária preparada para dialogar com o poder público tornando a relação de dominação menos vertical, mais capilar. O papel político que Jurandir passou a realizar deu mais visibilidade ao bairro que acabou servindo como propaganda política.

Os meandros da regularização fundiária: deslizamentos do conceito

A Lei Municipal que regula o programa de regularização fundiária em Londrina é a Lei no 12.215 de 2014. Entretanto, a Cohab-LD começou a promover a regularização fundiária com base na Lei no 11.977/2009 antes da aprovação da Lei Municipal. O primeiro assentamento atendido foi o Campos Verdes no município de Cambé, em área conurbada com Londrina. 
Até a aprovação da 11.977, a regularização fundiária dos lotes de interesse social era feita exclusivamente por meio do contrato de compra e venda e, por isso, realizada pelo Setor de Comercialização e Loteamento. A comercialização continua como opção na Lei Municipal no 12.215/2014, mas garante a gratuidade para ocupações anteriores a 2008, conforme instituído pela Lei Federal. Para ocupantes de períodos posteriores, são calculados descontos progressivos ${ }^{283}$. Essa Lei também regulamenta a operacionalização do atendimento dos beneficiários da regularização por regulamentação interna da Cohab-LD.

O Setor de Regularização Fundiária elaborou outro projeto de lei para regulamentar os procedimentos da regularização fundiária, que está em trâmite até o momento na prefeitura. Nesse projeto de lei, os pontos que se destacam em relação à lei anterior são a gratuidade total em substituição à comercialização e o uso da Concessão do Direito Real de Uso para ocupantes de períodos inferiores a cinco anos, que será substituída pelo título de propriedade após cinco anos. Essa Lei revogará todas as anteriores.

A primeira Lei Municipal que regulou a regularização fundiária em Londrina foi a Lei no 9.866 de 2005, que propunha a regularização por meio da "venda preferencial aos atuais ocupantes de imóveis". Já o Art. 17 autoriza a Cohab-LD a "outorgar a escritura definitiva de lotes ou unidades habitacionais, ainda que financiados, de sua propriedade, originários de assentamentos urbanos, favelas ou ocupações irregulares do Município de Londrina, aos ocupantes ou promitentes compradores existentes" até aquela data, "com os custos e os valores dos lotes absorvidos pela Cohab-LD". As duas leis aprovadas posteriormente - Lei 10.618/2008 e Lei 11.208/2011 - alteram apenas o artigo 17, para estender o prazo até 10 de janeiro de 2009, a posterior inclui um lote de Cambé à vigência da lei, e estende o prazo até 2011.

$283 \mathrm{O}$ artigo 17, parágrafo segundo, institui que o ocupante ou "promitente comprador", desde que comprove a "legítima sucessão e efetiva ocupação a partir de $1^{\circ}$ de janeiro de 2009 , poderá ser beneficiado com redução no valor de avaliação do imóvel para fins de comercialização de acordo com os critérios a seguir definidos":

I- $\quad$ Para regularização de ocupantes de 01/01/2009 a 31/12/2009: 80\% de desconto

II- Para regularização de ocupantes de 01/01/2010 a 31/12/2010: 60\% de desconto

III- Para regularização de ocupantes de 01/01/2011 a 31/12/2011: 40\% de desconto

IV- $\quad$ Para regularização de ocupantes de 01/01/2012 a 31/12/2012: $20 \%$ de desconto 
A partir dessa primeira aproximação com a legislação, observa-se que as leis não fazem menção a nenhuma intervenção física nos assentamentos e ficam restritas à definição de prazos, descontos e valores. A flexibilização dos prazos com a alteração das leis evidencia o caráter fluido desses instrumentos. Apesar dos altos índices de inadimplência e mobilidade da população, a comercialização dos lotes e a renegociação de dívidas continuam sendo abordadas como soluções.

Os núcleos incluídos no programa de regularização fundiária podem ser agrupados em duas categorias principais: núcleos que tiveram origem como ocupações irregulares e assentamentos e conjuntos habitacionais produzidos pelo poder público (Cohab-LD, Cohapar e recursos federais). O maior número de unidades (4.479) corresponde às ocupações irregulares. O menor número de unidades (2.513), distribuídas em maior número de núcleos, corresponde aos assentamentos e conjuntos habitacionais públicos que se encontram em situação de irregularidade fundiária. 
Tabela 7 - Núcleos regularizados no Programa de Regularização Fundiária

\begin{tabular}{|c|c|c|c|c|}
\hline $\begin{array}{c}\text { Núcleos em fase de regularização } \\
\text { fundiária }\end{array}$ & $\begin{array}{c}\text { № } \\
\text { famílias }\end{array}$ & $\begin{array}{l}\text { Registro do } \\
\text { Loteamento }\end{array}$ & $\begin{array}{l}\text { № título a } \\
\text { entregar }\end{array}$ & Região \\
\hline \multicolumn{5}{|c|}{ Ocupações em áreas públicas } \\
\hline Jardim Vila Ricardo-(Bananeiras) & 29 & $04 / 03 / 2016$ & 11 & LESTE \\
\hline Jardim União da Vitória I & 479 & 06/04/1990 & 116 & SUL \\
\hline Jardim União da Vitória II & 1572 & $31 / 07 / 1996$ & 538 & SUL \\
\hline Jardim Franciscato II & 142 & $18 / 05 / 2011$ & 69 & SUL \\
\hline Jardim Franciscato I & 132 & $22 / 11 / 2011$ & 31 & SUL \\
\hline Jardim Novo Perobal & 235 & 15/09/2016-20/09/1995 & 178 & SUL \\
\hline \multicolumn{5}{|c|}{ Ocupações em áreas particulares } \\
\hline Jardim João Turquino & 592 & 27/01/1997 & 41 & OESTE \\
\hline Jardim Maracanã & 639 & $19 / 06 / 2002$ & 35 & OESTE \\
\hline Jardim Monte Cristo & 454 & $27 / 03 / 2007$ & 121 & LESTE \\
\hline Jardim Leste-Oeste- Setor 1 & 165 & $15 / 05 / 2015$ & 70 & OESTE \\
\hline Vila Marizia I & 40 & $22 / 02 / 2006$ & 9 & $\begin{array}{c}\text { CENTR } \\
\mathrm{O}\end{array}$ \\
\hline \multicolumn{5}{|c|}{ Assentamento origem remoção } \\
\hline Jardim Primavera & 271 & $14 / 12 / 2005$ & 17 & NORTE \\
\hline Jardim Primavera I & 46 & 11/11/1999 & 1 & NORTE \\
\hline Jardim São Jorge & 751 & 03/04/2003 & 52 & NORTE \\
\hline Jardim Kobayshi & 41 & $15 / 09 / 2016$ & 41 & LESTE \\
\hline Jardim Morar Melhor & 70 & 19/08/1996 & 27 & SUL \\
\hline Jardim Santa Fé & 364 & 10/10/1999 & 132 & LESTE \\
\hline J. Vila Romana (OGU) & 18 & $11 / 05 / 2012$ & 0 & LESTE \\
\hline Jardim São Marcos & 160 & $01 / 09 / 2014$ & 40 & SUL \\
\hline \multicolumn{5}{|c|}{$\mathrm{CH}$ origem remoção de urbanização } \\
\hline C. H. José Belinati & 133 & $04 / 05 / 2015$ & 83 & NORTE \\
\hline Jardim Quati & 39 & $27 / 03 / 2006$ & 10 & NORTE \\
\hline Residencial Horizonte II (FNHIS 2009) & 293 & $30 / 08 / 2011$ & 293 & SUL \\
\hline J. Jamile Dequech (FNHIS 2008) & 10 & $12 / 11 / 2004$ & 0 & NORTE \\
\hline J.Nova Esperança (FNHIS 2008) & 62 & 19/04/1996 & 4 & SUL \\
\hline \multicolumn{5}{|c|}{ PAC-PPI } \\
\hline Jardim Novo Horizonte & 10 & $14 / 12 / 1999$ & 0 & NORTE \\
\hline Jardim Itapoã & 3 & 17/01/1997 & 0 & NORTE \\
\hline Jardim dos Campos & 85 & 29/11/2005 & 7 & NORTE \\
\hline Jardim Felicidade & 157 & $29 / 12 / 2003$ & 69 & NORTE \\
\hline Total & 6992 & & 1995 & \\
\hline
\end{tabular}

Fonte: Cohab-LD (2016). 
Figura 31 - Núcleos regularizados no Programa de Regularização Fundiária da Cohab-LD

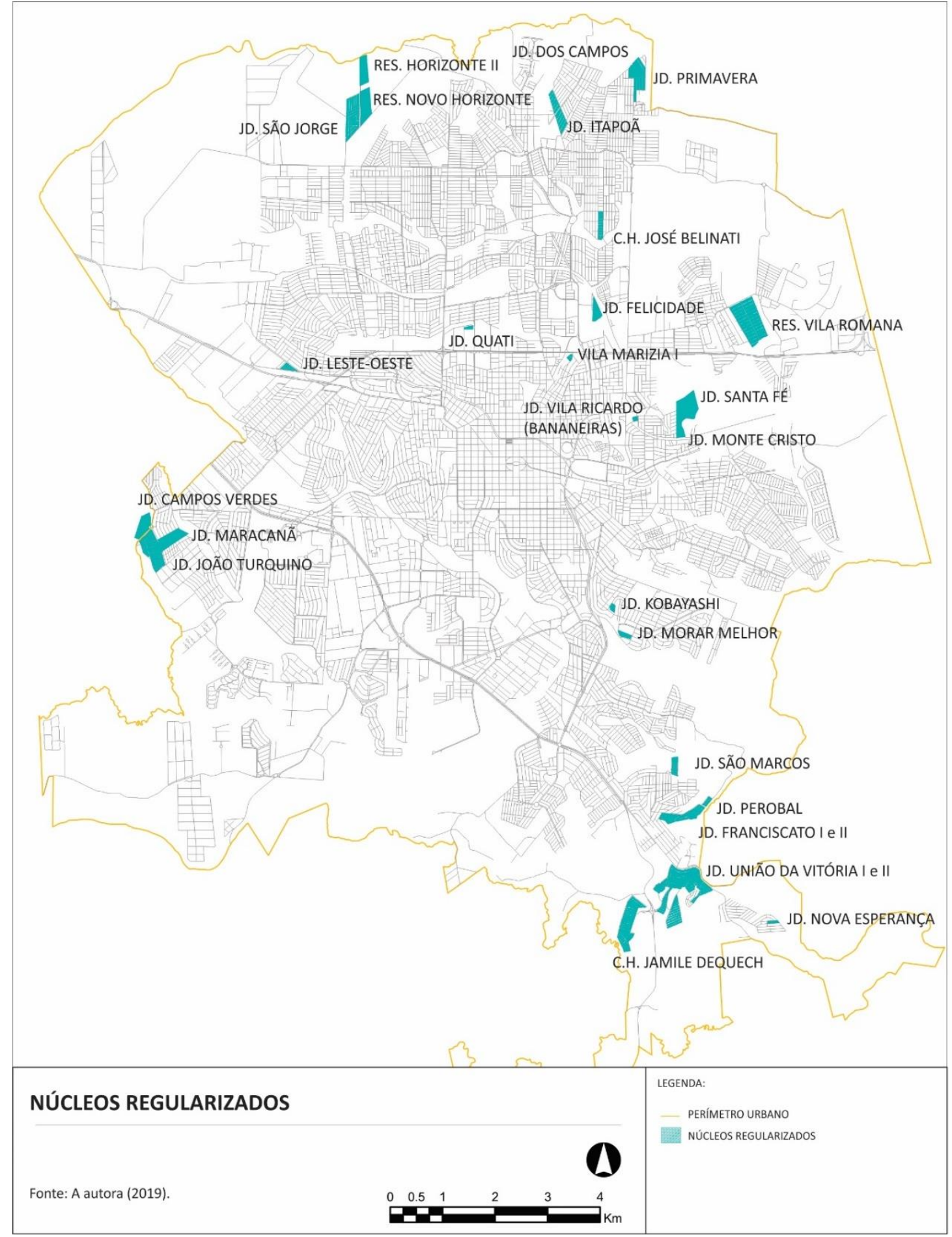

Fonte: Elaborado pela autora.

Dentre os núcleos que são conjuntos habitacionais, com exceção do C.H. José Belinati e do Jd. Quati, ambos da década de 1990, os demais foram produzidos e/ou urbanizados com recursos do PAC-PPI no final da década 1990 e começo da década de 2000, e do FNHIS 2008 e 2009. 
A questão mais relevante não é o fato de que parte da produção pública de moradia também é irregular, pois já foi discutido que a informalidade também é produzida pelo Estado, mas o fato de que tanto os assentamentos como alguns conjuntos habitacionais foram produzidos tendo como origem a remoção de famílias de outras áreas. Muitos, como discutido anteriormente, se formaram após a retirada das famílias de áreas de fundos de vale ou de ocupações em áreas particulares, depois passaram por obras de urbanização que, como mostra a tabela 7 , também provocaram remoções que deram origem a novos assentamentos. Assim, observa-se um ciclo de deslocamentos e informalidade gerados pelo Estado. A história do Jd. São Marcos apresentada no tópico anterior ilustra este processo.

Além do Jd. São Marcos, o histórico dos demais assentamentos permite verificar esse ciclo de deslocamentos que originaram os núcleos atendidos no Programa de Regularização Fundiária.

A história do Jardim São Jorge teve início a ocupação do Fundo de Vale (do córrego do paço fundo) do Conjunto Habitacional José Giordano. A reintegração foi pedida em seguida e a Cohab removeu uma parte das famílias para o Jardim João Turquino e outra parte das famílias foi para o terreno do atual Jardim São Jorge (próximo à área da ocupação original).

De acordo com documentos da Cohab-LD, o Jardim Kobayashi foi ocupado no começo da década de 2000, quando uma comissão de moradores do Conjunto Habitacional Nova Conquista reivindicou essa área vazia para a remoção de 40 famílias que residiam em condições precárias no bairro e foram identificadas em um diagnóstico da Cohab-LD para urbanização do conjunto. As famílias foram reassentadas na área de Jd. Kobayashi com a proposta de compra dos lotes por meio do Projeto Poupa Lar, porém nem todos receberam o boleto e se instalaram mesmo assim. As casas foram construídas pelos próprios moradores e os recursos para o parcelamento do bairro foram disponibilizados pela própria Cohab-LD. No mesmo ano da ocupação foram instaladas as redes de água e energia elétrica. Apenas uma rua do bairro era asfaltada (rua que faz a divisa com o Jardim Califórnia) e as demais ruas foram asfaltadas aproximadamente oito anos depois. No primeiro momento, o bairro foi dividido em 34 
lotes, e durante o levantamento realizado em 2013, identificou-se que esses lotes foram subdivididos e o bairro possuía 52 lotes.

O Jardim Morar Melhor é um loteamento urbanizado produzido pela Cohab-LD com recursos próprios na década de 90 (o loteamento foi aprovado em 1996), o único do Programa Morar Melhor, mesmo programa que promoveu a urbanização de uma série de assentamentos. Porém, a averbação da subdivisão dos lotes (casas geminadas) foi realizada apenas em 2010. O Jardim Morar Melhor teve duas fases de ocupação: a primeira, quando foram assentadas as famílias que ocupavam a área de preservação permanente na Rua Bélgica e a Favela Nova Conquista nas imediações. Os moradores que seriam atendidos participaram do mutirão de construção das unidades geminadas. A Favela Nova Conquista/Favela OK teve início em 1974, quando a área ainda era ocupada por chácaras com pasto e plantações de café. Os primeiros barracos foram construídos de forma dispersa, camuflados em meio à mata (IPPUL, 1996). A Favela foi urbanizada na década de 80 , e as famílias que foram removidas em decorrência das obras de urbanização foram reassentadas provisoriamente em casas construídas em madeira pela Cohab-LD em um terreno vazio do entorno (área que foi drenada) e, depois, foram para as casas do Jardim Morar Melhor.

Duas etapas de ocupações são referentes ao Jd. Monte Cristo. A primeira é de 1995, em que famílias de baixa renda ocuparam uma chácara particular de mais de mais de 2 alqueires na região leste de Londrina. De acordo com os documentos da Cohab-LD, inicialmente, cada família roçou e limpou uma porção do terreno e se instalou em barracos de lona. Os proprietários pediram a reintegração de posse no mesmo ano. A reintegração foi concedida pela justiça, mas não ocorreu a retirada dos moradores do local. Na época, a gestão era petista que atuou na periferia da zona leste, onde formou sua base eleitoral. Segundo reportagem da Folha de Londrina ${ }^{284}$, no início da década de 2000, a ocupação avançou sobre a área da sede da chácara de forma violenta, saquearam a casa da sede e, posteriormente, provocaram um incêndio. Nesse episódio o caseiro da chácara foi rendido por quatro horas. Entre os fatos passaram-se dois

284 Reportagem disponível em: https://www.folhadelondrina.com.br/cidades/casa-em-chacara-pegafogo-360107.html. Acesso em: 27/10/2019. 
meses. Nas reportagens, a filha do proprietário questiona a passividade do poder público em relação ao avanço da ocupação. Após esse fato, mais famílias ocuparam o terreno chegando a 490 famílias em 2003. Segundo a Cohab-LD, em 2004 (administração de Nedson Micheleti) foi dado início ao processo de urbanização da área - abertura de ruas, divisão dos lotes, instalação das redes de energia elétrica, água e esgoto - após a desapropriação da área. Os recursos para essas ações resultaram de uma parceria com a Cohapar, já que o Governo Estadual passou a subsidiar projetos de urbanização de favelas do Programa Direito de Morar ${ }^{285}$.

Nesse sentido, começado o assentamento, um recomeço para os moradores, a urbanização, as tentativas e poucas concretizações dos espaços comunitários foi um processo lento e que demandou iniciativa constante por parte dos moradores (principalmente da liderança comunitária) pressionando o poder público por décadas, com conquistas limitadas pelas intenções de cada gestão.

Nessa constante, os núcleos regularizados (ou em fase de regularização) são todos aqueles que não demandam nenhum tipo de investimento em infraestrutura e que já possuem a situação da posse resolvida e o loteamento aprovado. É a partir desse ponto que começa o trabalho de regularização fundiária previsto no Programa. Diante do conceito proposto pelo Ministério das Cidades, a "regularização fundiária plena", é possível dizer que o Programa de Regularização Fundiária realizado em Londrina, até o momento, corresponde apenas à titulação de imóveis, como veremos a seguir acerca dos procedimentos da regularização.

Para ilustrar o processo, o diagrama abaixo destaca o tempo de duração e a participação de outros setores da Cohab-LD em cada etapa da regularização fundiária. O organograma apresentado foi montado a partir do caso de regularização do assentamento “Campos Verdes" realizado em Cambé, na área conurbada com Londrina.

\footnotetext{
285 O Programa Direito de Morar propõe o enfrentamento das ocupações irregulares em municípios do Paraná. O programa tem como objetivo promover a regularização fundiária por meio de negociações diretas entre proprietários e ocupantes. O programa estabeleceu parceria com uma empresa privada Terra Nova Regularizações Fundiárias e atendeu os municípios de Colombo, Curitiba, Pinhais, Paranaguá e Matinhos. Informações disponíveis em: http://www.cohapar.pr.gov.br/modules/noticias/article.php?storyid=139. Acesso em: 27/10/2019.
} 
Essa foi a primeira experiência com base na Lei Federal no 11.977/2009 e passou a ser utilizada como referência para a execução dos demais processos.

Figura 32 - Diagrama dos procedimentos da regularização fundiária

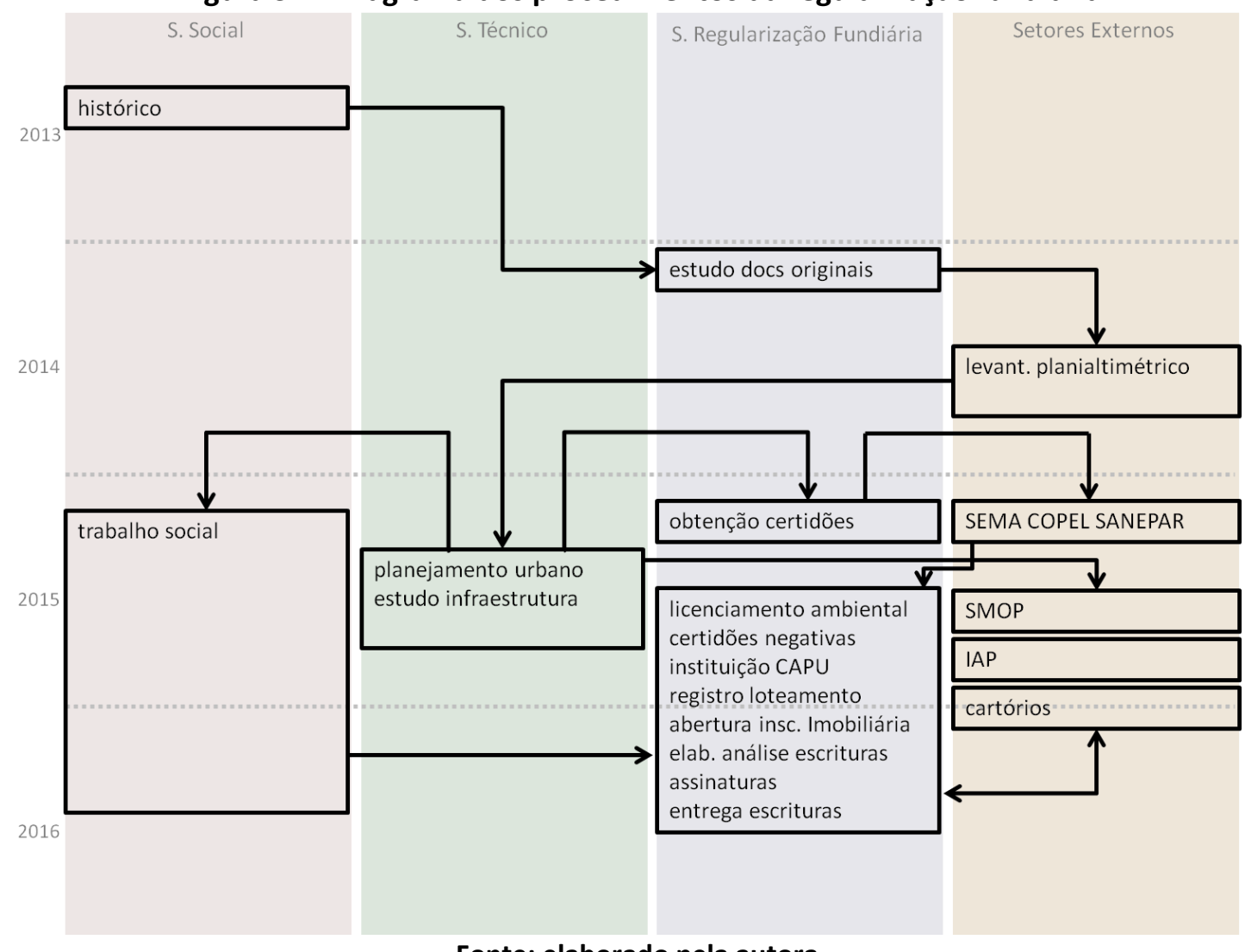

Fonte: elaborado pela autora.

A primeira etapa do procedimento da regularização é realizada pelo setor social e consiste na identificação e levantamento do histórico do núcleo para enquadramento na categoria de regularização fundiária de interesse social e assentamento consolidado.

Uma vez enquadrado como assentamento consolidado de interesse social, é encaminhado para o setor de regularização fundiária que dá início ao levantamento da documentação original do terreno junto ao cartório de registro de imóveis correspondente. Como a maior parte dos processos de regularização acontece em terrenos de domínio da Cohab-LD ou da PML - Prefeitura Municipal de Londrina -, para efetivar a regularização, todos os terrenos precisam estar em domínio da Cohab-LD e, portanto, é necessária a desafetação dos terrenos da prefeitura. 
Isto se deve ao fato de que a Cohab-LD é única instituição promotora da regularização fundiária, no caso de Londrina. Ainda, os contratos da regularização fundiária seguem os termos de um contrato de compra e venda realizada para fins de regularização fundiária. Nesses contratos, a Cohab-LD - proprietária dos imóveis -, vende pelo valor de $\mathrm{R} \$ 1,00^{286}$ para o ocupante. Realizado o contrato de compra e venda nestes termos, o ocupante recebe o título de legitimação de posse que poderá ser convertido em título de propriedade após cinco anos.

Segundo o diretor do setor de regularização fundiária esse processo é bastante lento. Além disso, diversos casos apresentam problemas na identificação do proprietário, conflitos nas matrículas dos terrenos, perda de documentos, entre outros fatos que atrasam os procedimentos. O caso mencionado do Jd. Leste-Oeste exemplifica bem essa dificuldade.

A matrícula do terreno em que está localizado o Jd. Leste-Oeste (Setor II) ainda estava no 10 Registro e nem mesmo o proprietário (Jockey Club) sabia da existência desta propriedade. Foi necessário um trabalho de pesquisa por parte da Cohab-LD até a identificação do proprietário. Após a notificação, outro problema se iniciou quando o proprietário decidiu reivindicar a posse do imóvel.

Ao mesmo tempo em que são resolvidas as demandas relacionadas ao domínio do imóvel, o setor de regularização encaminha a solicitação para terceirização do levantamento planialtimétrico do terreno - a Cohab-LD não possui profissional e equipamento de topografia. Depois, o levantamento é encaminhado ao setor técnico, em que o responsável pelo projeto do loteamento - um engenheiro agrimensor desenvolve o estudo do parcelamento e dá início aos estudos da demanda por infraestrutura (lembrando que já foram selecionados para esta etapa os núcleos em que não há a necessidade de realizar obras de infraestrutura).

O projeto finalizado é encaminhado para a aprovação pela Secretaria de Obras e Pavimentação. Nessa etapa, os funcionários chamam a atenção para as dificuldades de

\footnotetext{
${ }^{286}$ Este é o valor simbólico estipulado pela Cohab-LD para os casos em que está garantida a gratuidade,
} nos termos da Lei Municipal no 12.215/2014. 
diálogo com a SOP que, mesmo com o respaldo de Leis Federais, dificulta a aprovação do loteamento por utilizar os mesmos parâmetros dos loteamentos convencionais. A mesma crítica é feita ao IPPUL - Instituto de Pesquisa e Planejamento de Londrina. Segundo a Diretora Técnica, "o município não conhece a regularização, só a COHAB. Falta sensibilidade. O IPPUL não sabe de nada, só sabe a 6.766".

Simultaneamente à etapa do projeto começam os trabalhos do setor social para organização da comissão intitulada de CAPU - Comissão de Acompanhamento e Planejamento Urbano -, formada por técnicos da Cohab-LD e moradores que irão acompanhar todo o processo de regularização daquele momento em diante. A mobilização também é necessária para o levantamento da documentação individual dos moradores.

Sobre a mobilização, repetem-se as características discutidas sobre a remoção para conjuntos habitacionais. Novamente, os profissionais do setor social não possuem informações suficientes sobre o processo como um todo. Uma das entrevistadas que está responsável pela regularização fundiária do Assentamento União da Vitória disse que a equipe não recebe capacitação direcionada para essa finalidade. São apenas chamados pela chefia do setor que afirma que está em andamento a regularização fundiária de determinado bairro e, mesmo sabendo que esse processo tem especificidades, a equipe não recebe explicações do papel da regularização fundiária no contexto da política habitacional.

O Setor Comercial fez o preparo da equipe do Setor Social explicando como funciona a legislação que garante o direito à gratuidade dos ocupantes e os descontos progressivos. Portanto, a mobilização para regularização fundiária consiste na informação quanto ao direito à gratuidade e conscientização da comunidade para a coleta dos documentos.

Segundo a entrevistada, a coleta de documentos é um momento de grande dificuldade. Primeiro, porque nem todas as famílias possuem os documentos oficiais, muitas vezes declaram ter perdido ou nunca foram emitidos. Para resolver essas questões documentais, a Cohab-LD tem parceria com cursos de direito das faculdades 
locais que auxiliam as famílias a regularizar situações jurídicas diversas, como divórcio, e a obter outros tipos de documentos e certidões.

Outra grande dificuldade quando à documentação exigida pelo programa é a comprovação do tempo de moradia no local, condição para garantia da gratuidade. Foi necessário encontrar outras formas de comprovação que pudessem ser consideradas "documentos oficiais", como cadastro na UBS, endereço fornecido no prontuário médico, matrícula dos filhos nas escolas, etc.

Coletados os documentos e encaminhados para a advogada da seção de regularização fundiária, é quando começam os trabalhos mais intensos neste setor. Iniciam com a obtenção das certidões de viabilidade da COPEL - Companhia de Energia Elétrica - e da SANEPAR - Companhia de Saneamento - e, em seguida, o parecer ambiental é solicitado à SEMA - Secretaria do Meio Ambiente. O licenciamento ambiental emitido pelo IAP - Instituto Ambiental do Paraná - é necessário, no entanto pode haver a dispensa do licenciamento quando o assentamento possui infraestrutura, ou fornecido o licenciamento simplificado. Para os casos de ausência de infraestrutura (núcleos que não foram incluídos no programa), foi exigido um cronograma de obras de infraestrutura para a liberação.

Posteriormente, o cartório emite as certidões negativas do terreno. Depois, é realizado o registro do loteamento aprovado no cartório de registro de imóveis e executada a abertura da matrícula geral ou da matrícula "mãe" para a área demarcada e a abertura das matrículas para os lotes. Assim, registrado o loteamento, iniciam a elaboração e a análise das escrituras. Finalizam os trabalhos com a assinatura das escrituras.

Além de arcar com grande parte dos custos - a prefeitura também arca nos casos em que a regularização se dá em terreno da prefeitura, ao fazer a desafetação do terreno - a execução do programa depende de um conjunto de pareceres de diferentes órgãos, sendo que não há articulação entre eles, uma visão unificada sobre a política ou qualquer colaboração. Segundo os entrevistados, as secretarias do município não conhecem as funções da regularização fundiária, assim como o IPPUL, que toma como 
referência apenas os critérios básicos para aprovação de loteamentos contidos na Lei Federal no 6.766/1979. Portanto, falta sensibilidade e conhecimento para lidar com a questão, tornando o processo ainda mais lento e dispendioso.

Durante essa gestão (Kireff, 2013-2016) cessaram os recursos para a produção de conjuntos habitacionais, o que deixou, inclusive, um conjunto do PMCMV inacabado ${ }^{287}$. A escassez de recursos também contribuiu para a ênfase em ações de regularização fundiária. A Diretora Técnica defende atenção especial a programas de regularização fundiária tendo em vista que é uma política que "minimiza a necessidade de aquisição de novas áreas pela Cohab".

Observa-se que o procedimento é essencialmente burocrático, relativo à coleta de documentação que é reunida pela Cohab-LD e reconhecida pelos cartórios, e é o que confere legitimidade ao procedimento. Os advogados realizam a análise dos documentos, o engenheiro analisa a condição de infraestrutura dos bairros, o chefe da seção coordena a revisão dos documentos dos imóveis da Cohab-LD e os sociólogos e assistentes sociais auxiliam a comunidade a obter todos os documentos exigidos.

${ }^{287}$ Trata-se do Residencial Flores do Campo discutido anteriormente. 


\section{Um outro agente da política habitacional: o cartório de registro de imóveis}

Os detentores de ofícios estão numa contradição extraordinária porque sua ideologia, sua visão do mundo seus interesses os levam a estar do lado do direito e da transmissão controlada pelo direito, ao passo que seus interesses como corpos de pretensão nobiliária, tencionando transmitir os ofícios com a venalidade dos ofícios [...] os fazem pender para o lado da hereditariedade ${ }^{288}$

Quem não registra, não é dono

Esta frase, muito utilizada em Cartórios de Registro de Imóveis, tem um significado importante para compreender o papel do Registro de Imóveis na política habitacional, considerando que a propriedade privada é o principal modelo adotado ${ }^{289}$. Tanto para o registro da propriedade, como para qualquer procedimento imobiliário, como a comercialização, essa frase dá pistas do papel dos cartórios de registro.

Os altos custos do procedimento da regularização fundiária são apontados como uma das principais barreiras para sua execução, e as principais causas são as custas e emolumentos dos cartórios ${ }^{290}$. Portanto, além dos conflitos em relação ao reconhecimento da posse sobre a propriedade, a judicialização e o tempo do trâmite dos processos de usucapião, o preço dos procedimentos registrais também constituiu barreira para a regularização fundiária.

A política habitacional atual no Brasil, compreendida aqui como a articulação entre os programas habitacionais lançados pelo governo Federal desde a criação do

\footnotetext{
${ }^{288}$ Bourdieu (2014, p.404).

${ }^{289} \mathrm{Em}$ Londrina, todos os processos de regularização fundiária do programa analisado conferem o direito de propriedade, nos termos da usucapião ou como contrato de compra e venda. Não são utilizados outros instrumentos para esta finalidade, e a Concessão do Direito Real de Uso - CDRU - é usada apenas para situações pontuais, em unidades habitacionais dispersas, por prazo determinado e de forma onerosa, como alternativa de permissão de uso para casas em conjuntos habitacionais que são de propriedade da Cohab-LD. Como a Companhia é uma empresa de capital misto, os terrenos de propriedade da Cohab-LD podem ser usucapidos e comercializados. Para os casos em que a regularização fundiária é realizada em terrenos de propriedade da Prefeitura do Município de Londrina, no lugar do uso da CDRU, optou-se por desafetar para a Cohab-LD antes de promover a regularização fundiária em benefício do ocupante.

290 Sobre isso, ver Rolnik et. al. (2007).
} 
Ministério das Cidades (agora, extinto), seja pelo Programa Minha Casa Minha Vida, por meio da comercialização (financiamento) de unidades habitacionais, seja por meio da Regularização Fundiária de Interesse Social, perpassa necessariamente pelo registro imobiliário. Mesmo para os casos de Regularização Fundiária em terrenos públicos, é necessário registrar os diferentes tipos de concessão de uso (direito real ou especial para fins de moradia) no Registro de Imóveis competente.

Nesse sentido, e principalmente ao aprofundar no procedimento da regularização fundiária regulado pelas Leis Federais no 11.977/2009 e № 13.465/2017, observa-se que o Cartório de Registro de Imóveis tem papel central na legalização dos imóveis ocupados, por ser o agente responsável pela emissão da documentação que regulariza (e legitima) a situação da posse do imóvel. Ironicamente, essa concentração das ações previstas nas leis recentes decorre da iniciativa do governo federal de desburocratizar e desjudicializar os procedimentos da regularização fundiária ${ }^{291}$.

Constatada essa centralidade dos cartórios nos procedimentos imobiliários e para compreender o papel exercido pelos Cartórios de Registro de Imóveis no campo da política habitacional, passei a acompanhar a participação dos cartórios nos debates sobre os programas habitacionais, realizei a análise de documentos, realizei pesquisa bibliográfica e entrevistas com cartorários diretamente ligados aos procedimentos do Programa de Regularização Fundiária de Londrina ${ }^{292}$ e nacional.

Por meio desta "extensão" do meu campo de pesquisa, pude constatar que estamos assistindo a uma reestruturação nos procedimentos imobiliários no Brasil, em que a regularização fundiária tem um papel que não se restringe ao atendimento

\footnotetext{
${ }^{291}$ Carvalho (2007).

${ }^{292}$ A pesquisa foi realizada no cartório Canziani, 2o Cartório de Registro de Imóveis de Londrina. Este cartório foi escolhido por ter estabelecido convênio com a Cohab-LD para a promoção da regularização fundiária e por ter ligação direta com a organização dos Colóquios de Direito Imobiliário e Urbanístico organizados pela $\mathrm{OAB}$, que debateram o tema da regularização fundiária por três edições consecutivas. Porém, o posicionamento do Cartório Canziani - indicado nas entrevistas da Cohab-LD - favorável à regularização de interesse social, deve ser interpretado sem desconsiderar a relação da família Canziani com a política, principalmente relacionada a este público localizado na área de abrangência da zona norte, onde predomina a população de baixa renda. Alex Canziani (ex-deputado federal) foi vice do Belinati na gestão já discutida, marcada pelo populismo e corrupção.
} 
habitacional. Primeiro, vejamos o papel dos Cartórios de Registro no Programa de Regularização Fundiária, para depois analisar este contexto mais amplo.

Os procedimentos referentes à regularização fundiária de interesse social realizados pelos cartórios de registro de imóveis nos termos da Lei Federal no 11.977/2009 iniciam com o auto de demarcação urbanística, que consiste em um ato administrativo em que o agente promotor da regularização anuncia a intenção de regularizar aquele assentamento. O auto deve reunir todos os documentos que demonstrem as características da área demarcada. Os documentos devem seguir as orientações dos incisos I, II e III do § 1ㅇ do Art. 56 da Lei Federal no 11.977/2009²93. Neste momento o cartório é procurado pelo agente executor para solicitar a averbação do auto de demarcação urbanística, quando este documento - que representa a intenção de regularizar - é protocolado no cartório correspondente à circunscrição em que está localizada a área a regularizar. Após o protocolo, cabe ao cartório identificar o proprietário e a respectiva matrícula do imóvel. No caso de a área abranger mais de uma circunscrição, o coordenador do processo deve ser o cartório onde se localiza a maior porção da área demarcada 294 .

Depois de concluída a averbação do auto de demarcação, o município desenvolve e aprova o projeto de parcelamento da área, que retorna ao cartório para o registro do parcelamento resultante do projeto. Registrado o parcelamento, o cartório executa a abertura da matrícula para a área demarcada e a abertura da matrícula para cada parcela do loteamento, bem como das áreas públicas. Uma vez registrado o parcelamento, é efetuada a emissão do título de legitimação de posse pelo poder

\footnotetext{
${ }^{293}$ Art. 56. O poder público responsável pela regularização fundiária de interesse social poderá lavrar auto de demarcação urbanística, com base no levantamento da situação da área a ser regularizada e na caracterização da ocupação.

$\S$ 1ㅇ O auto de demarcação urbanística deve ser instruído com:

I - planta e memorial descritivo da área a ser regularizada, nos quais constem suas medidas perimetrais, área total, confrontantes, coordenadas preferencialmente georreferenciadas dos vértices definidores de seus limites, número das matrículas ou transcrições atingidas, indicação dos proprietários identificados e ocorrência de situações mencionadas no inciso I do § 5 ㅇ

II - planta de sobreposição do imóvel demarcado com a situação da área constante do registro de imóveis e, quando possível, com a identificação das situações mencionadas no inciso I do § 5o; e

III - certidão da matrícula ou transcrição da área a ser regularizada, emitida pelo registro de imóveis, ou, diante de sua inexistência, das circunscrições imobiliárias anteriormente competentes.

294 Instituto de Registro Imobiliário do Brasil (2012).
} 
público e este também deve ser registrado no cartório. A partir deste registro começa a contar o prazo (cinco anos) para a conversão do título de legitimação de posse em propriedade, nos termos da Usucapião. Passado o prazo estabelecido, é o requerente que solicita ao cartório o registro da conversão do título de legitimação de posse em título de propriedade 295

Com relação ao percurso do registro nos setores do cartório ${ }^{296}$, começa no setor de atendimento (que pode ser realizado como atendimento pessoal, quando requisitado), e vai para o setor de protocolo, onde "começa a vida do título". Quando o interessado recebe o número do protocolo ele está com o direito do registro garantido no prazo determinado pela Lei (30 dias). Após o protocolo, é encaminhado para o cadastro, onde é feita a ligação do imóvel à pessoa. Este cadastro é realizado no Livro 1 de protocolo e é inserido direto no sistema informatizado. Depois do cadastro, passa pela qualificação registral. Os registros qualificados são encaminhados para o setor de etiqueta, onde é feita a etiqueta e a assinatura - o que corresponde ao ato registral - e depois é digitalizado e inserido no sistema. Portanto, quando chega a esta etapa, o ato já foi registrado. $\mathrm{O}$ ato pode corresponder ao registro ou à uma abertura de matrícula. O setor de protocolo também recepciona os pedidos de certidões, que são expedidas para garantir publicidade aos atos registrados. A cobrança dos emolumentos é realizada antecipadamente com base em valores tabelados e, se houver diferença a pagar ou receber, esse ajuste acontece no final do procedimento.

Os custos de tais procedimentos são considerados muito altos, mesmo para procedimentos imobiliários do mercado formal, que não são de interesse social. No caso da política habitacional, os altos custos cobrados pelos cartórios representam impacto para o poder público (quando assume essa responsabilidade), que precisa encarar um processo burocrático de recolhimento de documentos e caro, por assumir o registro do parcelamento do solo e da incorporação, e também a abertura e registro de cada matrícula individual. Nos casos em que os beneficiários de determinado programa habitacional são responsáveis pelo registro da sua matrícula individual, os custos são

\footnotetext{
295 Instituto de Registro Imobiliário do Brasil (2012).

296 Procedimento levantado no Cartório Canziani (2o Cartório de Registro de Imóveis de Londrina).
} 
inviáveis considerando a característica de "baixa renda" das famílias atendidas que, em grande parte das vezes, deixam de registrar o imóvel, iniciando um novo ciclo de ilegalidade. Ainda, em grande parte das cidades brasileiras (senão em todas) em que historicamente foram produzidos conjuntos habitacionais, observa-se que a maior parte deles não teve sequer o registro do loteamento realizado pelo Poder Público.

Por isso, está previsto por lei desconto de $75 \%$ para o registro dos imóveis financiados com recursos do FAR (para imóveis produzidos pelo PMCMV). No caso de Londrina, foi relatado em entrevista que o valor a ser pago está em torno de $\mathrm{R} \$ 350$ e $\mathrm{R} \$ 360$ reais, já com o desconto por unidade. Os valores cheios corresponderiam a $\mathrm{R} \$$ 800 pelo registro normal, e mais $\mathrm{R} \$ 400$ pelo registro de garantia. Mesmo com o desconto, para renda de até 3 salários mínimos, são valores altos. Segundo a entrevistada do 2ํ Cartório de Registro de Imóveis de Londrina (Cartório Canziani), agora (2018), após 6 anos da entrega das unidades do Residencial Vista Bela, é que começaram a efetuar os registros. Quando questionada sobre a demora dos registros, disse que a causa está relacionada ao custo e, por isso, nenhum morador registrou. Agora, a Caixa Econômica assumiu essa dívida e está providenciando os registros.

Também por esse motivo, a gratuidade do primeiro registro do imóvel no caso de regularização fundiária de interesse social foi amplamente discutida e, finalmente, regulada. A necessidade de reconfigurar o sistema cartorial no que tange ao registro de imóveis para fins de regularização fundiária foi reconhecida em 2004, e resultou em um convênio firmado entre o Ministério das Cidades e a Associação dos Notários e Registradores do Brasil - Anoreg ${ }^{297}$. Ficou, assim, aprovado em Lei Federal ( $n$ ㅇ 10.931 de 2004, no Art. 213, § 15), “Não são devidos custas ou emolumentos notariais ou de registro decorrentes de regularização fundiária de interesse social a cargo da administração pública". Nesse período, em Londrina, foi realizado o Convênio entre o 2ำ Registro de Imóveis e a Cohab-LD, em que o juiz corregedor estabeleceu a gratuidade de $R \$ 50$ correspondentes às custas, enquanto $R \$ 130$ eram pagos pela Cohab-LD. Em

\footnotetext{
${ }^{297}$ Fernandes (2007).
} 
Londrina este convênio foi realizado para regularizar loteamentos irregulares/clandestinos.

Somente com o texto da Lei Federal no 11.977/2009 foi garantida a gratuidade total das custas e emolumentos referentes à regularização fundiária de interesse social. Considerando todas as ações que são empreendidas pelos cartórios na previsão da Lei Federal no 11.977/2009, de acordo com os termos do Art. 68 da Lei, a isenção dos emolumentos é dada para os atos de abertura de matrícula para a área demarcada, se esta não possuir matrícula, e abertura de matrículas para todas as parcelas resultantes da execução do projeto de regularização fundiária; para a averbação do auto de demarcação urbanística; para registro do título de legitimação de posse; para o registro de conversão do título de legitimação em propriedade; e para o registro dos parcelamentos resultantes da execução do projeto de regularização.

Entretanto, a gratuidade de custas e emolumentos para os registros da regularização fundiária de interesse social tem sido objeto de disputa no campo legislativo, fato evidente nos trâmites das alterações e revogação do Capítulo III da Lei Federal no 11.977/2009, no texto da MP no 759/2016, e no texto final da Lei Federal no 13.465/2017. Antes disso, a alteração da Lei Federal no 11.977/2009 promovida pela Lei Federal no 12.424/2011, libera da gratuidade a averbação da extinção do título de Legitimação de Posse, e a averbação da extinção da Concessão do Direito Real de Uso.

Portanto, é fato que houve resistência por parte da classe dos registradores em relação à gratuidade das custas e emolumentos. Em Londrina um dos cartórios (3으 Registro) se recusou a não cobrar e, por isso, foi necessária a intervenção do Juiz Corregedor para notificar o cartório da irregularidade.

Para a entrevistada do 2을 Registro de Imóveis de Londrina, as opiniões em relação à gratuidade estão realmente divididas. Para ela, os cartórios menores têm dificuldade em se manter já que os serviços prestados são de alguma forma afetados pelas dinâmicas econômicas do país. Com toda a demanda gerada pela nova legislação e as exigências de prazos que passaram a existir, é fato que levaria alguns cartórios, de cidades menores, por exemplo, a fechar. De qualquer forma, ela acredita que isto não 
importa, já que este seria um caso de fazer cumprir uma função social, e que poderia ser garantido ao menos pelos cartórios que têm as condições para fazer.

Apesar de o Cartório de Registro de Imóveis ser abordado como o "carro chefe" da arrecadação dos cartórios pelo cartorário Lamana Paiva ${ }^{298}$, o argumento dado pelo representante do Ministério das Cidades - Sílvio Figueiredo - em defesa dos cartórios é de que mais de $50 \%$ deles têm faturamento inferior ao custo da sua manutenção, o que levou a um gargalo nos processos de regularização. Por isso, justificou o pagamento das custas e emolumentos por meio do Fundo Nacional de Habitação, que consiste em uma das alterações promovidas pela Lei Federal no 13.465/2017.

Quanto às garantias da gratuidade para viabilizar os processos de regularização em larga escala, a primeira coisa que o município precisa fazer é declarar o interesse social.

A isenção hoje, sob a vigência da Lei Federal no 13.465/2017, se restringe aos cartórios de Registro de Imóveis, porém teria que se expandir também para outras instâncias (tabelionato, cartórios de protesto), tendo em vista que em grande parte dos processos de regularização são necessárias certidões de outros órgãos, antes da emissão do título.

Além da gratuidade, outro papel de ampla relevância assumido pelos Cartórios de Registro de Imóveis no contexto das políticas habitacionais, é o incentivo dado pela Lei Federal à resolução extrajudicial de conflitos, que se refere à dispensa da intervenção judicial aos processos de usucapião299. Desse modo, desde a Lei Federal no 11.977/2009,

\footnotetext{
298 João Pedro Lamana Paiva foi citado diversas vezes por vários entrevistados, tanto na Cohab-LD, como no Cartório Canziani. Também foi palestrante em todas as edições do Colóquio de Direito Imobiliário e Urbanístico. Lamana Paiva tem certo protagonismo no âmbito dos Cartórios de Registro de Imóveis, e dentre suas publicações recentes está o texto sobre a Regularização Fundiária. É registrador titular do Registro de Imóveis da 1a Zona de Porto Alegre (RS) e foi presidente do Instituto de Registro Imobiliário do Brasil - IRIB - em 2015/2016. Esteve presente nos Encontros do IRIB desde 1977, e foi vice-presidente nas gestões de 2006-2009 e de 2013-2014. Participou, ainda, ativamente em diversas diretorias do Instituto em outras gestões. Atualmente, é membro do Comitê Latino-americano de Consulta Registral e membro do conselho de ética da Associação dos Notários e Registradores do Brasil - Anoreg/BR (IRIB, 2019. Disponível em: https://www.irib.org.br/pessoas/joao-pedro-lamana-paiva. Acesso em: 28/10/2019).

${ }^{299}$ Consta no Art. 48 da Lei Federal no 11.977/2009 e Art. 10, Art. 21 e Art. 31 da Lei Federal no 13.465/2017.
} 
a Usucapião Extrajudicial foi prevista e, com a regulamentação prevista no Provimento 65 , ela se efetiva e passa a ser realizada no Cartório de Registro de Imóveis ${ }^{300}$.

A usucapião extrajudicial é defendida principalmente pela burocratização e demora dos processos da usucapião judicial (convencional), o que é complicado para os casos de regularização fundiária de ocupações urbanas informais tendo em vista a mobilidade da população e a dificuldade de ter controle dos ocupantes e da dinâmica da ocupação e, por isso, com o passar do tempo, a irregularidade muda, se transforma e, no fim do processo, a área encontra-se ocupada por outras famílias.

Ainda, no Capítulo II que a Lei Federal no 11.977/2009 destina ao tema do registro de imóveis, também foi regulado o sistema de registro eletrônico no Brasil. Sobre esse capítulo falarei mais adiante neste mesmo tópico.

Identificado, portanto, esse papel de importância dos cartórios no contexto dos programas habitacionais, não apenas devido aos custos e a disputa pela gratuidade, ou pela importância atribuída ao registro do imóvel, mas também pelo papel assumido no âmbito da sentença relativa ao conflito fundiário, procurei compreender com mais profundidade a origem e o funcionamento dos cartórios no Brasil e qual seu papel sobretudo na política de regularização fundiária pretendida a partir da Lei Federal no 11.977 de 2009.

\section{Os cartórios e o pensamento proprietário}

Na tentativa de compreender a origem e os fundamentos da atuação dos Cartórios de Registros no Brasil, destaco o panorama construído por Silva (2014) que se inicia na vigência do sistema de Sesmarias, do início da colonização do Brasil, que funcionava como o que mais se aproxima de uma normativa para a propriedade de bens imóveis. O primeiro destaque do autor é relativo ao marco jurídico de 1548 quando é

\footnotetext{
300 Em Londrina, foi aplicada a resolução de conflitos extrajudicial no 2 Cartório de Registro pela entrevistada. A conciliação pode ser feita pelo Cartorário, mas para a mediação de conflito o Conselho Nacional de Justiça - CNJ - exige um curso preparatório oferecido pela escola da ANOREG para que o cartório esteja apto a realizar mais essa atividade.
} 
estabelecido o Governo Geral, que atua como uma administração central da qual fazem parte as capitanias hereditárias. O autor destaca ainda que essa mesma Lei passa a exigir o registro de todas as Cartas de Sesmarias expedidas.

Os marcos que se destacam no histórico do registro de imóveis no Brasil acompanham os marcos que remetem à propriedade privada da terra.

As Sesmarias permaneceram em vigência no Brasil até 1822, mas até este momento, a partir de 1808, todas as concessões eram centralizadas, e a partir de 1809 as concessões passaram a ser acompanhadas de medições judiciais, instituindo maior critério. Entretanto, em 1822 foram suspensas as concessões de Sesmarias em decorrência justamente de conflitos em torno da posse ${ }^{301}$. Em 1824, após a independência do Brasil, é regulamentada a Constituição Imperial que "tem por base a liberdade, a segurança individual e a propriedade" inspirada nos dispositivos do Código Civil Francês de matriz liberal, sendo que contraditoriamente a sociedade imperial brasileira naquele momento tinha como pilares econômicos o latifúndio agrícola e a mão de obra escrava ${ }^{302}$

Em 1888, momento da abolição da escravidão no Brasil, se iniciou uma transformação no pensamento econômico no Brasil, em que a riqueza até então concentrada no escravo é transferida para a terra, e isso foi possível dado o respaldo da Lei de Terras aprovada em 1850, que representa o marco da individualização da propriedade imobiliária brasileira e institui a compra como a única forma de aquisição da propriedade imobiliária no Brasil ${ }^{303}$.

Assim, os traços da Lei de Terras responderam aos anseios de preservação da propriedade privada no Brasil, decorrentes da discussão sobre abolição da escravidão que já pairava pela Europa. Como, no Brasil, a economia (e, consequentemente, o poder) estava fundamentalmente pautada na produção agrícola pelo trabalho escravo, as garantias da Lei de Terras vieram no sentido de preservar a propriedade da terra no

\footnotetext{
301 Silva (2014).

302 Silva (2014, p.64).

${ }^{303}$ Silva (2014); Rolnik (2007); Fernandes (2007); Alfonsin (2007).
} 
caso de questionamento da validade da propriedade do escravo. Foi nessa mesma época que o sistema de registro também se aprimorou.

Quatro anos após a aprovação da Lei de Terras, foi criado o "Registro do Vigário", principal marco para a matéria do registro de imóveis, que tratava de um levantamento estatístico dos possuidores das terras devolutas que agora podiam registrar e legitimar a posse. Dez anos depois foi regulamentado oficialmente como Registro Geral, sobre o qual Silva (2014, p.77) destaca que "o atual registro de imóveis é, em verdade, uma atualização do Registro Geral, criado pela Lei no 1.237 de 24 de setembro de 1864".

Fortalecendo a individualização e mercantilização da terra, após a Proclamação da República, a regulamentação do Código Civil em 1916 consolidou o pensamento liberal no Direito Civil e, influenciado pelo esboço de Teixeira de Freitas, mantém a ideia da propriedade privada constituída pelo registro de imóveis ${ }^{304}$. Diferente da proposta original para o Código Civil, o texto aprovado retira o artigo que tratava das obrigações do proprietário.

Nesse sentido, observa-se que a consolidação do registro de imóveis no Brasil se deu na mesma medida em que a propriedade imobiliária assumiu papel de mercadoria de valor econômico e do fortalecimento do direito de propriedade, o que enfatiza seu papel de controle e de reforço das estruturas que garantem o pleno direito de propriedade.

Desse modo, os cartórios de registro de imóveis alinham-se ao pensamento proprietário no Brasil, estando na sua origem ligados ao fortalecimento da propriedade privada no contexto da economia nacional. Ainda, são profissionais do Direito formados ${ }^{305}$ na tradição do direito civil de matriz liberal. De acordo com a Lei Federal no 8.935 de 1994 que dispõe sobre serviços notariais e de registro (também conhecida como Lei dos Cartórios), estão regulamentados:

\footnotetext{
${ }^{304}$ Alfonsin (2007); Silva (2014).

305 Devem ser bacharéis em Direito ou exercer a atividade por pelo menos dez anos a partir da data de publicação do edital do concurso.
} 
Art. 10 Serviços notariais e de registro são os de organização técnica e administrativa destinados a garantir a publicidade, autenticidade, segurança e eficácia dos atos jurídicos.

Art. 3o Notário, ou tabelião, e oficial de registro, ou registrador, são profissionais do direito, dotados de fé pública, a quem é delegado o exercício da atividade notarial e de registro.

Como visto, a entrevistada reconhece que sua formação teve ênfase no Direito Civil e que este teve um protagonismo em relação ao Direito Público. Para ela, a Constituição Federal de 1988 é analítica e traz disposições sobre os direitos fundamentais e, ainda, outros direitos que ela abrange. Segundo ela, a Constituição Federal privilegiou a função social da propriedade, porém isto ainda não está totalmente incorporado na visão do intérprete. Ela reforça que "o registrador está sempre em compasso de espera, está observando, se ele não é provocado ele não pode fazer nada", e como essa nova regulação proposta para a regularização fundiária desde 2009 representa uma "grande virada", foi recebida com relutância pelos registradores que temem gerar insegurança jurídica no que tange à propriedade.

O fato de ter como formação uma matriz liberal clássica com foco no Direito Civil interfere diretamente na interpretação da situação posse/propriedade, ou seja, na visão do cartorário sobre o papel da regularização fundiária. Em todos os eventos que frequentei onde cartorários discutiam a regularização fundiária, a resistência a respeito do tema era latente. Sem dúvida o vínculo da própria criação e função dos cartórios com o surgimento e fortalecimento da noção de propriedade privada é condicionante. Mas, para compreender como isto interfere diretamente no cotidiano do cartório no que se refere aos processos de regularização, cabe iniciar a reflexão a partir de alguns conceitos fundamentais que embasam a interpretação e a atuação dos cartórios de registro de imóveis: os direitos reais e o conceito de segurança jurídica, frequentemente citados nas palestras, discussões e entrevistas.

A primeira questão é que dentre treze direitos ${ }^{306}$ considerados direitos reais pelo Art. 1.225 do Código Civil, o primeiro deles é a propriedade, e a posse não está

${ }^{306}$ Dentre eles foram incluídos posteriormente decorrente das novas normas de regularização fundiária a Concessão de Uso Especial para Fins de Moradia; a Concessão de Direito Real de Uso; os direitos oriundos 
enumerada entre esses direitos e, portanto, não é considerada um direito real. Não existe margem para esta interpretação por sua característica de enumeração taxativa dos direitos reais na norma que é proposital na sua essência para evitar a criação de outros tipos de direito de propriedade que não aqueles já previstos pela legislação ${ }^{307}$.

(...) que o Código Civil, no artigo 524, define o direito de propriedade (síntese dos direitos reais) sob tais aspectos, decorrentes do poder direto (uso, fruição e alienação) e do poder absoluto (seqüela ou reivindicação), como se pode conferir: A lei assegura ao proprietário o direito de usar, gozar e dispor de seus bens, e de reavê-los do poder de quem quer que injustamente os possua. ${ }^{308}$.

E é justamente o Cartório de registro de imóveis que vai assegurar, por meio da transcrição e da publicidade, o direito do proprietário.

Cerca de noventa por cento dos direitos reais são constituídos por meio da compra e venda, da permuta, da doação e da dação em pagamento (inclusive em hasta pública e desapropriação ou venda compulsória). Os demais o são por acessão, usucapião, sucessão hereditária e outros restritos modos de aquisição. Daí a importância da tradição como modo de aquisição dos móveis e da transcrição do título no registro imobiliário para a constituição dos direitos reais sobre os imóveis. Em nosso direito civil, não basta o consentimento das partes nos contratos para se adquirir o domínio ou outro direito real. $O$ efeito constitutivo decorre da tradição ou entrega real ou simbólica ou formal dos móveis e da transcrição do contrato ou título respectivo no registro imobiliário da situação do imóvel. Numa palavra, o requisito do direito real é a publicidade, por meio da tradição e da transcrição ${ }^{309}$.

No caso do sistema romano-germânico adotado no direito brasileiro ${ }^{310}$, o domínio dos imóveis é transferido pela tradição (entrega do bem) e pela transcrição

\footnotetext{
da imissão provisória da posse, quando concedida à União, aos Estados, ao Distrito Federal, aos Municípios ou às suas entidades delegadas e respectiva cessão e promessa de cessão; e a laje.

${ }^{307}$ Dantas (2018).

${ }^{308}$ Costa (1999, p.72).

${ }^{309}$ Costa (1999, p.72/73).

310 O sistema romano-germânico, ou Civil-Law originalmente adotado no Brasil apresenta as normativas organizadas em códigos e de caráter generalista. Segundo Fernandes (2001), nas últimas décadas
} 
(transmissão transcrita no livro de transcrições) e não apenas pelo contrato, o que coloca o registro imobiliário no centro dessa questão. Costa $(1999$, p. 74$)$ mostra esta relação destacando as funções atribuídas ao registro dos imóveis:

Tema correlato é o das funções atribuídas ao registro imobiliário, que são as seguintes: a) publicidade: tal como a lei, o direito real, (...), deve ser divulgado para conhecimento e segurança de terceiros, os quais têm livre acesso ao cadastro por meio de certidões com fé pública; b) constitutiva do direito real: se a publicidade é a segurança de terceiros, a função constitutiva do direito real é a segurança do titular, que vê nascer o seu direito por meio do registro do título ou contrato. É o que ocorre na hipótese do artigo 530, I, do Código Civil; c) função declaratória: atua nas hipóteses do artigo 530, II, III e IV, do Código Civil - aquisição pelos modos autônomos da acessão, do usucapião e do direito hereditário, os quais independem de transcrição para constituir o direito real. $\mathrm{O}$ registro se faz com efeito declaratório apenas, a fim de aperfeiçoar um direito real já constituído por outro modo autônomo. Serve inclusive para valorizar o direito real, ensejando a sua alienação e constituição de outros direitos reais (hipoteca, servidão); d) continuidade ou seqüência: é a função histórica do registro, vinculando os títulos causais e facilitando o acesso à evolução dos direitos reais sobre determinado imóvel; e) função probatória: o registro imobiliário, mediante certidões expedidas livremente, constitui prova do direito real, aceita sem contestação enquanto não for alterado o registro pelos meios legais.

Como forma de adquirir a propriedade, como foi citado, pode ser por tradição, quando a aquisição se dá por meio de contrato e, quando a posse é reconhecida, a propriedade pode ser adquirida por meio da Usucapião. Como o termo ocupação pressupõe o reconhecimento legal da posse, destaca-se a importância na precisão dos termos "invasão" e "ocupação" nos discursos.

Entretanto, tendo em vista que historicamente apenas os direitos reais típicos podem ser registrados garantindo a publicidade do título, a inclusão em registro dos instrumentos que reconhecem a posse no processo de regularização é um importante tensionamento da visão hegemônica da propriedade no direito brasileiro.

assistimos a uma "americanização" do direito brasileiro, que seria a influência do sistema Common-Law utilizado nos Estados Unidos, em que as normas são aplicadas sempre com base em um precedente jurisprudencial que foi gerado pelo próprio sistema. 
Além do direito de propriedade fortemente amparado no Código Civil, por outro lado, o Direito à Moradia tratado na CF, no capítulo que abrange os direitos sociais, foi incluído por emenda apenas em 2000, e pode ser interpretado tanto como direito fundamental de primeira como de segunda dimensão ${ }^{311}$. Por esse motivo, em determinadas situações em que o direito à moradia pode confrontar outros direitos, como o de propriedade, no caso de uma ocupação de área particular, o direito à moradia interpretado como fundamental de primeira dimensão poderia levantar questionamento sobre como deve proceder o Estado em relação aos ocupantes em uma ação de reintegração de posse. Entretanto, olhando apenas do ponto de vista do código civil, os "invasores" não têm direito algum.

É justamente por causa dessas normas, e dessa forma de interpretação decorrente da formação conservadora dos cartorários, que a segurança jurídica atribuída como função dos cartórios pode ser outro obstáculo na interpretação do conceito da regularização fundiária. Este aspecto central do papel dos registros de imóveis na sociedade, a segurança jurídica - bastante enfatizada nas entrevistas - é garantida pelo cadastro e publicidade decorrentes do ato de registro do imóvel.

De acordo com os questionamentos dos cartorários em relação aos conflitos fundiários, o papel do cartório ficaria ambíguo ao ter como função a garantia da segurança jurídica, enquanto dá a usucapião em detrimento do proprietário original. A preocupação constante dos cartorários é de como isso pode comprometer e trazer riscos para o cartorário, tendo em vista que existem medidas de punição previstas na Lei dos Cartórios.

A ênfase na segurança jurídica ocorre devido à histórica precariedade no Registro de Imóveis no Brasil. Apesar de ser uma atividade consolidada e antiga, os procedimentos evoluíram pouco em dois séculos de existência. A primeira modernização significativa no procedimento dos registros é com relação ao vínculo do

\footnotetext{
${ }^{311}$ Facchini (2019). Os direitos fundamentais de primeira dimensão são ligados à noção de liberdade, civis ou políticos, e por isso têm caráter negativo, ou seja, exigem que o Estado não interfira na garantia do direito. Já os direitos fundamentais de segunda dimensão são direitos culturais, econômicos e sociais e de caráter positivo, ou seja, que demandam uma ação do Estado como forma de garantir esses direitos. Existem ainda os direitos de terceira e quarta dimensão (Novelino, 2009).
} 
imóvel a uma matrícula única, que ocorreu em 1973, com a aprovação da Lei Federal no 6.015. Até então, os lançamentos eram feitos em uma sequência única nos livros correspondentes a cada ato registral de transmissão ou averbação, por exemplo. Portanto, não havia uma única descrição do imóvel, com as características físicas, identificação do proprietário, os registros e as averbações. Estas informações ficavam dispersas nos livros. Além disso, quando apenas parte do imóvel era vendido, permanecia uma descrição com a área total e o nome do proprietário, e depois outro ato era realizado com o novo proprietário da área desmembrada. Dessa forma, o controle era bastante precário, com grande quantidade de informações imprecisas sobrepostas. São imprecisas pois as informações lançadas no ato do registro não exigiam dados como RG, CPF, portanto lançava-se apenas o nome, estado civil, cidade de domicílio, etc. Por esses motivos, a segurança jurídica era muito baixa, evidenciando mais uma vez a manutenção do atraso que dificultou o controle sobre a terra, que marca o desenvolvimento econômico brasileiro.

Com a abertura da matrícula do imóvel, todos os atos relativos àquele imóvel ficam registrados na mesma matrícula.

Devido à importância dada à noção de segurança jurídica (apesar da precariedade e inconsistências nos atos de registro), segundo a entrevistada, os avanços promovidos pela legislação para a promoção da regularização fundiária só serão efetivos se houver esforço por parte dos registradores na desconstrução do pensamento proprietário consolidado, bem como abandonar a ilusão da cidade ideal. É necessário encarar a realidade das cidades e, para ela, é isto que o legislador, quando visualizou a desburocratização do procedimento da regularização, se propôs a fazer.

\section{Alinhamento com as premissas do Banco Mundial}

Nas entrevistas e palestras dos Cartórios de Registro, o Banco Mundial foi diversas vezes citado como referência para o tema da regularização fundiária. A 
definição de diretrizes do Banco Mundial para influenciar economias não é nova, e foi alvo de análise nas pesquisas de Arantes e Maranhão ${ }^{312}$.

Ao investigar a relação entre os registros de imóveis no Brasil e as agências multilaterais, surgiu a avaliação realizada pelo Banco Mundial, dentre outros aspectos, dos atributos do sistema de registro de propriedade (inclusive a fundiária) no Projeto Doing Business.

O Doing Business realiza uma análise do ambiente de negócios em 190 economias $^{313}$.

A proposta do Banco é criar uma ferramenta para mensurar o impacto das regulamentações existentes em cada país sobre as atividades empresariais. Com a finalidade de reforçar os pressupostos de agilidade e eficiência empresariais característicos do BM, compara as regulações que interferem nas atividades empresariais criando uma classificação dos melhores ambientes de negócios. Segundo consta no site do Projeto, essa é uma forma de incentivar os países a buscar uma "regulação mais eficiente", o que pressupõe uma flexibilização e, assim, adquirir maior competitividade no cenário internacional por meio de "reformas regulatórias" nos ambientes de negócios locais.

O Brasil hoje está classificado em 1370 na categoria do registro de propriedade, mas classificado em 109 na classificação geral das economias para fazer negócios.

\footnotetext{
312 Arantes (2004) e Maranhão (2009). Arantes (2004), na análise da agenda proposta pelas instituições multilaterais para a América Latina, enfatiza a importância do discurso na propagação dos princípios neoliberais pelas instituições: "O uso da ciência, da habilidade na produção discursiva e a inegável capacidade de realização (...) são instrumentos poderosos da hegemonia das instituições financeiras multilaterais. (...) Tal discurso, originário dos poucos 'centros de comando discursivos', tem a capacidade acadêmica de traduzir uma posição política em termos técnicos." (Arantes, 2004, p.21). Com base nessa disseminação dos princípios neoliberais para a agenda urbana, segundo Maranhão (2009) a "boa governança" se estrutura com base na boa governa, reformas institucionais e redução da pobreza, propagando os princípios financistas para todas as esferas de vida. Assim, a governabilidade passa a ser mensurada pela "capacidade dos governos de alinharem as reformas orientadas para o mercado às condições institucionais capazes de estabilizar os agentes econômicos ao cumprimento dessas reformas" (Maranhão, 2009, p.47).

313 Banco Mundial (2019). Disponível no site do Programa Doing Business em: https://portugues.doingbusiness.org/pt/doingbusiness. Acesso em: 28/10/2019.
} 
Para a classificação, foram elencados critérios que, segundo o Banco Mundial, indicam a facilidade de fazer negócios. Um desses critérios - que nos interessa diretamente para esta análise - é quanto ao Registro de Propriedades, inclusive a imobiliária.

Neste critério, a avaliação do Doing Business confere todas as etapas necessárias para que um comprador possa adquirir uma propriedade de um vendedor com a transferência de título de propriedade, de forma que seja possível utilizá-la como investimento no seu negócio, seja vendendo a um terceiro ou utilizando como garantia de empréstimo. Este tópico também abrange tanto a eficiência do processo de transferência da propriedade, como o que se chama de índice de qualidade do sistema de administração fundiária.

Para a análise da eficiência do processo de transferência de propriedades, são analisados os procedimentos, entendidos como toda a interação necessária entre os agentes que participam do processo; o tempo, mensurado em dias corridos necessários para a execução de cada procedimento e as possibilidades de redução do tempo, mesmo que mediante pagamento; e o custo, analisado como um percentual do preço total da propriedade, e são adicionados apenas os custos oficiais das transações.

Com relação à qualidade da administração fundiária, a análise é feita a partir de cinco variáveis adotadas como critérios de qualidade, a saber: qualidade da infraestrutura, transparência das informações, cobertura geográfica, resolução de disputas fundiárias e igualdade do direito de propriedade. 
Tabela 8 - Índices que compõem a qualidade da administração fundiária

\begin{tabular}{|c|c|c|c|c|c|}
\hline & \multicolumn{5}{|c|}{ Índices } \\
\hline & $\begin{array}{l}\text { Índice da qualidade da } \\
\text { infraestrutura }\end{array}$ & $\begin{array}{l}\text { Índice da transparência das } \\
\text { informações }\end{array}$ & $\begin{array}{l}\text { Índice da cobertura } \\
\text { geográfica }\end{array}$ & $\begin{array}{l}\text { Índice da resolução de } \\
\text { disputas fundiárias }\end{array}$ & $\begin{array}{l}\text { Índice da igualdade } \\
\text { dos direitos de } \\
\text { propriedade }\end{array}$ \\
\hline \multirow[t]{10}{*}{$\begin{array}{c}\text { Itens } \\
\text { analisados }\end{array}$} & $\begin{array}{l}\text { Como os títulos de } \\
\text { imóveis são mantidos } \\
\text { no registro da cidade. } \\
\text { (digitalizados ou não) }\end{array}$ & $\begin{array}{l}\text { Se as informações sobre a } \\
\text { propriedade de imóveis estão } \\
\text { disponiveis ao público }\end{array}$ & $\begin{array}{l}\text { Quão completa é a } \\
\text { cobertura do registro } \\
\text { de imóveis ou } \\
\text { registro fundiário na } \\
\text { maior cidade } \\
\text { comercial }\end{array}$ & $\begin{array}{l}\text { Se a lei exige que todas } \\
\text { as transações de venda } \\
\text { de propriedades sejam } \\
\text { registradas no registro } \\
\text { de imóveis para torná- } \\
\text { las oponíveis a } \\
\text { terceiros }\end{array}$ & $\begin{array}{l}\text { Se mulheres } \\
\text { solteiras e homens } \\
\text { solteiros têm os } \\
\text { mesmos direitos de } \\
\text { propriedade }\end{array}$ \\
\hline & $\begin{array}{l}\text { Se existe um banco de } \\
\text { dados eletrônico para } \\
\text { verificar gravames }\end{array}$ & $\begin{array}{l}\text { Se a lista de documentos } \\
\text { necessários para a realização } \\
\text { do registro da transação está } \\
\text { disponível ao público }\end{array}$ & $\begin{array}{l}\text { Quão completa é a } \\
\text { cobertura do registro } \\
\text { de imóveis a nível } \\
\text { nacional }\end{array}$ & $\begin{array}{l}\text { Se um sistema formal } \\
\text { de registro de bens } \\
\text { imóveis está sujeito a } \\
\text { uma garantia }\end{array}$ & $\begin{array}{l}\text { Se mulheres } \\
\text { casadas e homens } \\
\text { casados têm os } \\
\text { mesmos direitos de } \\
\text { propriedade }\end{array}$ \\
\hline & $\begin{array}{l}\text { Como as plantas dos } \\
\text { lotes são mantidas no } \\
\text { órgão de mapeamento } \\
\text { da cidade }\end{array}$ & $\begin{array}{l}\text { Se a tabela de taxas e preços } \\
\text { para realizar o registro da } \\
\text { transação imobiliária está } \\
\text { disponível ao público }\end{array}$ & $\begin{array}{l}\text { Quão completa é a } \\
\text { cobertura do órgão } \\
\text { de mapeamento } \\
\text { cadastral na maior } \\
\text { cidade comercial }\end{array}$ & $\begin{array}{l}\text { Se existe um } \\
\text { mecanismo } \\
\text { extrajudicial específico } \\
\text { de indenização para } \\
\text { cobrir os prejuízos } \\
\text { incorridos pelas partes } \\
\text { (...) que teve com base } \\
\text { informações errôneas } \\
\text { certificadas pelo } \\
\text { cartório de bens } \\
\text { imóveis }\end{array}$ & \\
\hline & $\begin{array}{l}\text { Se existe um sistema } \\
\text { de informações } \\
\text { geográficas - um banco } \\
\text { de dados eletrônico } \\
\text { para registrar limites da } \\
\text { propriedade, verificar } \\
\text { as plantas e fornecer } \\
\text { informações cadastrais }\end{array}$ & $\begin{array}{l}\text { Se o órgão responsável pelo } \\
\text { registro de bens imóveis se } \\
\text { compromete a fornecer } \\
\text { dentro de um prazo específico } \\
\text { um documento juridicamente } \\
\text { vinculativo que comprove a } \\
\text { propriedade do imóvel }\end{array}$ & $\begin{array}{l}\text { Quão completa é a } \\
\text { cobertura do órgão } \\
\text { de mapeamento } \\
\text { cadastral a nível } \\
\text { nacional }\end{array}$ & $\begin{array}{l}\text { Se o sistema jurídico } \\
\text { exige uma verificação } \\
\text { da validade legal dos } \\
\text { documentos (tais como } \\
\text { a escritura de venda, } \\
\text { transferência ou } \\
\text { trespasse) necessários } \\
\text { para uma transação de } \\
\text { propriedade }\end{array}$ & \\
\hline & $\begin{array}{l}\text { Se o registro de } \\
\text { imóveis e o órgão de } \\
\text { mapeamento cadastral } \\
\text { estão interligados. }\end{array}$ & $\begin{array}{l}\text { Se existe um mecanismo } \\
\text { específico e independente } \\
\text { para protocolar queixas acerca } \\
\text { de um problema que tenha } \\
\text { ocorrido no órgão responsável } \\
\text { pelo registro de bens imóveis }\end{array}$ & & $\begin{array}{l}\text { Se o sistema jurídico } \\
\text { exige uma verificação } \\
\text { da identidade das } \\
\text { partes de uma } \\
\text { transação de } \\
\text { propriedade } \\
\end{array}$ & \\
\hline & $\begin{array}{l}\text { Como os bens imóveis } \\
\text { são identificados }\end{array}$ & $\begin{array}{l}\text { Se existirem estatísticas } \\
\text { oficiais disponíveis ao público } \\
\text { a respeito do número de } \\
\text { transações no órgão de } \\
\text { registro de bens imóveis }\end{array}$ & & $\begin{array}{l}\text { Se há um banco de } \\
\text { dados nacional para } \\
\text { confirmar a exatidão } \\
\text { dos documentos de } \\
\text { identidade }\end{array}$ & \\
\hline & & $\begin{array}{l}\text { Se os mapas ou plantas dos } \\
\text { lotes estão disponíveis ao } \\
\text { público }\end{array}$ & & $\begin{array}{l}\text { Qual é o tempo } \\
\text { necessário para se } \\
\text { obter uma decisão de } \\
\text { um tribunal de } \\
\text { primeira instância (sem } \\
\text { recurso) em uma } \\
\text { disputa fundiária entre } \\
\text { duas empresas locais } \\
\text { por direitos de posse } \\
(\ldots)\end{array}$ & \\
\hline & & $\begin{array}{l}\text { Se a tabela de preços e taxas } \\
\text { para acesso aos mapas está } \\
\text { disponível ao público }\end{array}$ & & $\begin{array}{l}\text { Se existem estatísticas } \\
\text { disponíveis ao público } \\
\text { sobre o número de } \\
\text { disputas fundiárias em } \\
\text { primeira instância }\end{array}$ & \\
\hline & & $\begin{array}{l}\text { Se o órgão de mapeamento se } \\
\text { compromete a fornecer } \\
\text { dentro de um prazo específico } \\
\text { um mapa atualizado }\end{array}$ & & & \\
\hline & & $\begin{array}{l}\text { Se existe um mecanismo } \\
\text { específico e independente } \\
\text { para protocolar queixas acerca } \\
\text { der um problema que tenha } \\
\text { ocorrido no órgão } \\
\text { encarregado do mapeamento }\end{array}$ & & & \\
\hline
\end{tabular}

Fonte: Banco Mundial, 2019. Disponível em: ttps://portugues.doingbusiness.org/pt/doingbusiness 
Logo no primeiro tópico, da qualidade da infraestrutura, o primeiro atributo analisado é referente à manutenção dos títulos em cada cidade e a pontuação máxima é atribuída para os casos em que a maioria dos títulos dos imóveis encontra-se totalmente digitalizada.

Essa é uma informação importante tendo em vista que o Capítulo II da Lei Federal no 11.977/2009 regulamenta a criação do registro de imóveis digital no Brasil. Com base na previsão legal, todo o banco de dados físico dos cartórios será inserido em um sistema eletrônico único nacional e será protocolado em meio eletrônico acelerando a troca de informações pelo meio digital. A entrevistada do 2 Cartório de Registro de Imóveis de Londrina acredita que essa inovação que irá centralizar as informações garantirá celeridade às transações imobiliárias e garantirá maior segurança jurídica.

Ela informa que é um grande problema, hoje, o fato de não ter um cadastro único entre prefeitura e registradores de imóveis, bem como dos registros de imóveis e Incra. Por isso, muitas vezes estes órgãos possuem cadastros diferentes o que atrapalha principalmente o controle da arrecadação de impostos municipais. Em Londrina, isso provocou um problema na última revisão da Planta de Valores que acarretou na revisão das cobranças de IPTU. As incoerências ${ }^{314}$ que foram alvo de muitas críticas são resultantes desses cadastros conflitantes.

A digitalização do documento, assim como a criação de uma única plataforma que permita a comunicação entre diferentes cartórios que compartilham documentos, significavam, além da segurança, agilidade (redução do tempo de tramitação) e publicidade. Segundo a entrevistada há de fato interesse de que o poder público disponibilize as informações sobre os imóveis brasileiros e, portanto, essa é uma das finalidades do registro eletrônico. Do mesmo modo, a regularização fundiária em massa significa maior controle e precisão, principalmente associada à criação de um sistema único de registro eletrônico nacional.

\footnotetext{
${ }^{314} \mathrm{Em}$ Londrina, devido à ilegalidade da situação dos loteamentos fechados, eles constam como uma matrícula que tem uma única cobrança de IPTU que é dividida entre todos os condôminos, resultando em valores muito baixos por unidade e acusou uma discrepância muito grande em relação às áreas de baixa renda.
} 
Lamana Paiva resgata a ideia de De Soto (2000) como lição (e mostra como isto está de fato incorporado no pensamento legislativo e judiciário, sobretudo no âmbito do registro dos imóveis), da importância do Brasil se dedicar à regularização fundiária para a promoção do desenvolvimento.

Ele destaca ainda, (compatibilizando a visão de De Soto com as normativas dos bancos) que os bancos estrangeiros começaram a investir no Brasil depois de 2006, que coincide com o amadurecimento do instrumento da alienação fiduciária.

Estas questões são reforçadas na entrevista no cartório de Londrina. Segundo a entrevistada, as diretrizes do Banco Mundial tiveram muita influência sobre a regulação da regularização fundiária no Brasil. Ela argumenta que um dos principais problemas em nível jurídico no Brasil é a informalidade que, segundo ela, contribui muito para que a camada de menor poder aquisitivo não tenha acesso a recursos para montar um negócio, por não ter o que oferecer como garantia. Dessa forma, ela argumenta que como a pessoa não tem bens para garantir a abertura de um negócio, ela permanece na informalidade. Por isso, ela acredita que por trás da lei há de fato esse conceito econômico, um conceito de desenvolvimento e "giro econômico", uma tendência do legislador de ampliar o acesso à propriedade.

Ela vê a função do cartório como a garantia da segurança jurídica ao procedimento da regularização fundiária. Para ela é uma função de cautela, que previne conflitos e assegura direitos.

Lamana Paiva ${ }^{315}$ reforça o papel dos cartórios citando o artigo 1.240 do Código Civil: "Só é dono quem registra". Segundo ele, o direito à moradia está intimamente ligado ao direito de propriedade. Eles não se confundem, mas se relacionam. Nesse sentido, ele chega a questionar se a regularização fundiária tem como fim garantir o direito de moradia ou o direito de propriedade? Em resposta à retórica, ele diz que tem que ter o título e o registro.

Segundo Lamana Paiva, o registro de imóveis foi o destinatário final da regularização fundiária. Ele aborda a Regularização Fundiária sob dois aspectos: dos

\footnotetext{
315 Na palestra sobre Regularização Fundiária no II Colóquio de Direito Imobiliário de Londrina (2016).
} 
"impactos e aspectos relacionados ao desenvolvimento das cidades e do direito à moradia" e também do ponto de vista econômico, em que ele relaciona "cidades sustentáveis" ao "combate da irregularidade". "É muito mais do que a 11.977/2009 e agora a 13.465/2017".

Trata a regularização fundiária como estratégia de "cumprimento e observância nos meios normais (ordinários)... chega de extraordinários!". É dito que o cartorário é quem representa o Estado e o que está em vista pelo judiciário é o caminho para a normalidade, para que a regularização extraordinária deixe de ser regra.

Nesse sentido, observa-se que o marco regulatório é visto também como estratégia de prevenção, que é citada em vários momentos. Para ele o Art.9o da Lei Federal no 13.465/2017 na abordagem da regularização fundiária dos núcleos urbanos por meio da legitimação fundiária é o principal marco regulatório para que o poder público municipal se torne o grande protagonista para evitar a proliferação de irregularidades.

Art. 9o Ficam instituídas no território nacional normas gerais e procedimentos aplicáveis à Regularização Fundiária Urbana (Reurb), a qual abrange medidas jurídicas, urbanísticas, ambientais e sociais destinadas à incorporação dos núcleos urbanos informais ao ordenamento territorial urbano e à titulação de seus ocupantes.

$\S 10$ Os poderes públicos formularão e desenvolverão no espaço urbano as políticas de suas competências de acordo com os princípios de sustentabilidade econômica, social e ambiental e ordenação territorial, buscando a ocupação do solo de maneira eficiente, combinando seu uso de forma funcional.

$\S 2$ A Reurb promovida mediante legitimação fundiária somente poderá ser aplicada para os núcleos urbanos informais comprovadamente existentes, na forma desta Lei, até 22 de dezembro de 2016. 


\section{Mudanças recentes com relação aos procedimentos imobiliários}

Está havendo uma mudança drástica na legislação dos negócios imobiliários ${ }^{316}$

Durante os colóquios, seminários e reuniões que participei, apesar de o foco central ser o tema da regularização fundiária, outros instrumentos da legislação que regulam procedimentos imobiliários foram discutidos de forma articulada com a regularização. Por isso, ficou claro de que há intenção de reestruturação no campo fundiário e que as mudanças nos instrumentos legais procuram legitimar essas mudanças que têm como foco a criação de um ambiente favorável aos negócios com garantias confiáveis a investidores e credores, sobretudo internacionais.

Uma das principais mudanças referentes aos procedimentos imobiliários no Brasil abordada juntamente com o debate sobre a regularização fundiária é a Alienação Fiduciária de Bens Imóveis.

Trata-se de um novo instituto, considerado mais eficiente e que incide sobre os Direitos Reais de Garantia (hipoteca, penhor, etc.) mas que, ao contrário da hipoteca, garante que o imóvel seja transferido ao credor, mantendo o domínio do imóvel ao credor no caso de inadimplência. Desse modo não se aplica, como no caso do penhor ou da hipoteca, a judicialização para transferência do domínio do imóvel.

Segundo Melhim Chalhub, autor da monografia que originou a primeira lei sobre alienação fiduciária de bens imóveis, essa é uma "figura de garantia" nas transações imobiliárias que envolvem crédito.

Com relação ao sistema de financiamento imobiliário referente ao instituto da alienação fiduciária, a primeira lei aprovada foi a Lei Federal no 9.514/1997 e, depois, a Lei Federal no 10.931/2004. Agora, a Lei Federal no 13.465/2017 incorpora a alienação

${ }^{316}$ Fala de Melhim Chalhub, autor da monografia que originou a primeira lei sobre alienação fiduciária, no III Colóquio de Direito Imobiliário e Urbanístico de Londrina (2017). 
fiduciária para imóveis comercializados no âmbito da Caixa Econômica Federal, no PMCMV, ou seja, para imóveis de interesse social.

Essa foi a participação de Challhub na revisão do texto da Lei Federal no 11.977/2009, a adaptação do instrumento da alienação fiduciária para ser aplicada aos financiamentos da Caixa Econômica Federal.

Tendo em vista a grande ampliação do crédito imobiliário para faixas de renda até então não contempladas, principalmente no Brasil, o papel assumido pelos bens imóveis como lastro da economia financeirizada, além do episódio da "bolha imobiliária" nos EUA, verifica-se no Brasil a preocupação com a "garantia" dos credores nas operações que envolvem o financiamento imobiliário.

Trata-se de um "negócio jurídico pelo qual o devedor (fiduciante), com o escopo de garantia, contrata a transferência ao credor (fiduciário) da propriedade resolúvel da coisa imóvel"317. Na sua origem, esse instrumento foi criado para a comercialização de automóveis e era utilizada exclusivamente pelas instituições financeiras. Foi incorporada às operações imobiliárias no contexto da expansão de crédito imobiliário, mas se limitava à compra e reforma. Em 2015 o STF ampliou sua aplicação para qualquer operação de crédito.

Em contratos que utilizam a alienação fiduciária, o imóvel em negociação permanece em nome do credor e só é passado para o nome do comprador quando o imóvel for quitado. No caso de inadimplência por atraso nos pagamentos das parcelas, o comprador tem um prazo de 45 dias para quitar as parcelas em atraso. Se não quitar, o comprador perde todo o valor pago e o imóvel retorna para o domínio do credor e vai a leilão, sem a necessidade de judicialização. Nesses termos, o devedor não tem nenhuma garantia, mesmo se tratando do único bem imóvel.

O direito do fiduciário não se equivale à propriedade plena prevista no Art. 1.231 do Código Civil ${ }^{318}$, pois o credor fiduciário não terá o poder jurídico sobre o bem imóvel

${ }^{317}$ Brasil (1997). Lei Federal no 9.514 de 1997.

318 Isso está colocado no Art. 1.367 do Código Civil. 
já que a regra impõe a obrigatoriedade do leilão na retomada do imóvel, e o fiduciário terá direito apenas sobre o dinheiro resultante da venda do imóvel no leilão.

Considerando o cenário após a realização das hipotecas nos EUA, em que os bancos retomaram os imóveis, essa parece ser uma solução para equilibrar um cenário como aquele. Porém, para os financiamentos de interesse social, em que os índices de inadimplência são altos por razões óbvias, este instrumento pode levar ao agravamento da situação habitacional no Brasil.

Outra alteração é a Lei Federal no 13.097/2015 que trata do “Princípio da concentração". O Princípio da Concentração é um instrumento relacionado à publicidade dos atos e à eliminação dos riscos nas transações econômicas que envolvem os imóveis. O objetivo do instrumento é concentrar todas as informações do imóvel de modo que qualquer situação jurídica que não estiver presente na matrícula, não atinge o imóvel. Dessa forma, objetiva-se desestimular os "contratos de gaveta".

Esse instrumento transforma a matrícula em uma única fonte de informações sobre o imóvel, trazendo maior segurança jurídica às transações referentes aos negócios imobiliários. Além da segurança jurídica, outras vantagens apontadas em defesa do instrumento são: a desburocratização dos procedimentos dos negócios imobiliários, redução de custos e celeridade, bem como o afastamento de riscos de fraudes ${ }^{319}$.

Considerando essas mudanças, pela fala sobre a Lei Federal no 11.977/2009 observa-se uma tentativa de convencimento dos cartorários que estavam resistentes em relação à gratuidade das custas e emolumentos e em relação à solução de conflitos em relação à proprietários e ocupantes. A fala é em termos de incentivo aos cartorários e o principal argumento utilizado é de que a Lei dá o respaldo necessário aos cartorários para que eles atuem nessa mediação dos conflitos. Outro argumento em relação à gratuidade é de que uma vez regularizados todos os procedimentos pelos quais passarem esses imóveis serão registrados em cartórios, e a incorporação dessa grande quantidade de imóveis irregulares, a médio e longo prazo, contribuirá significativamente para a arrecadação dos cartórios.

${ }^{319}$ Richter (2004). 
Como o Cartório de Registro de Imóveis tem como papel e responsabilidade a segurança jurídica da propriedade, e todos os riscos de punição que a Lei dos Cartórios prevê, foram necessárias intervenções de provimentos e corregedoria para respaldar e orientar os cartorários (como, por exemplo, o Provimento 44 de 2015).

Na visão do cartorário Lamana Paiva, a Regularização Fundiária compreende a regularização do assentamento (compreendendo as medidas definidas na lei) e a titulação dos seus ocupantes e, com isso, promovem a regularização documental e, assim, a segurança jurídica. Desse modo, ele defende que os imóveis regularizados oferecem a garantia da tributação e a possibilidade da obtenção de crédito. O papel do cartório, portanto, neste contexto, é apresentar as soluções jurídicas para possibilitar a regularização fundiária.

Sobre a revogação do Capítulo III, defende-se que por meio dessa Lei se possibilita o acesso de todo imóvel ao sistema registral e ao mercado formal, argumentando inclusive que isso é vantajoso pois o Estado passa a ganhar com a cobrança de IPTU e aqueles que deixam de ser posseiros passam a reformar o imóvel. 


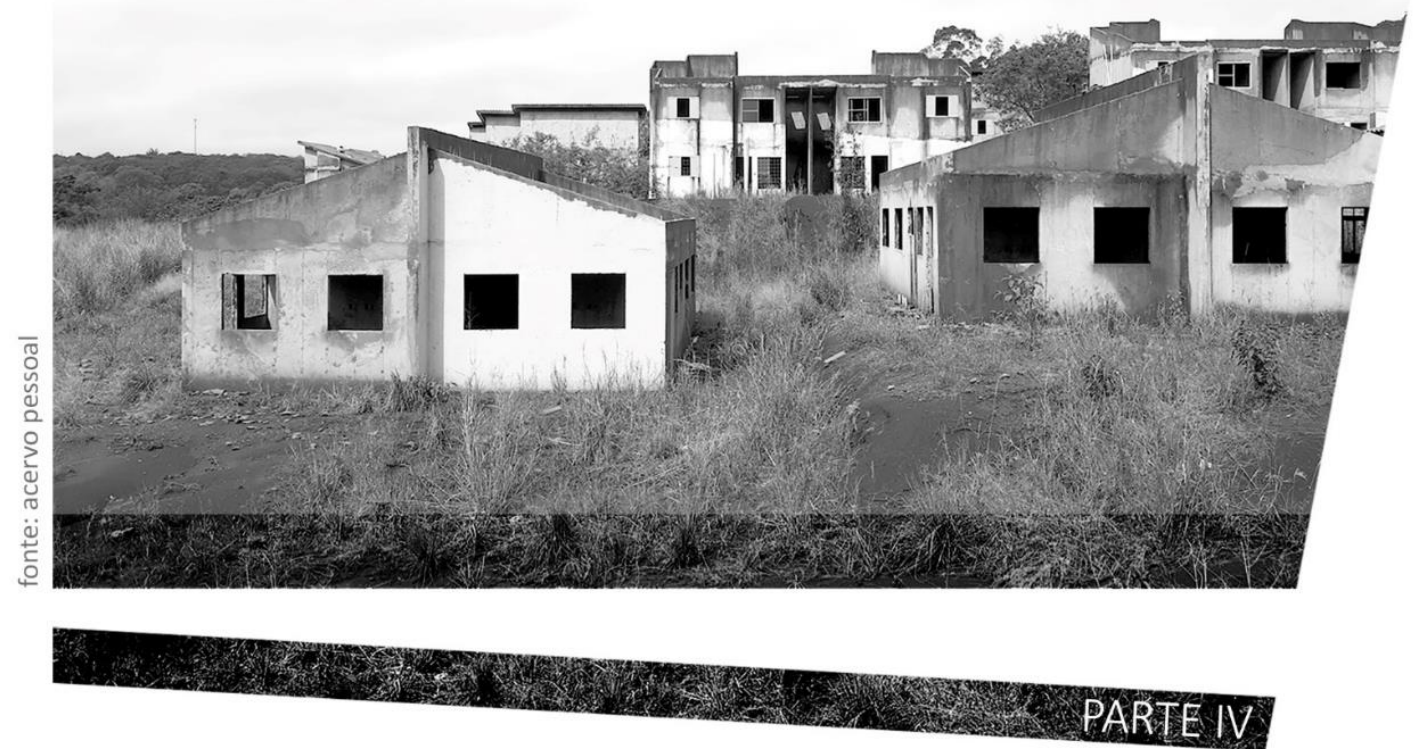




\section{Programas habitacionais e a gestão dos ilegalismos urbanos}

Os agentes que atuam nos processos descritos - Cohab-LD, Cartórios de Registro de Imóveis, Ministério Público, Judiciário - representam o Estado na sua heterogeneidade e estão, de diferentes formas, ligados aos direitos de propriedade. Por outro lado, as ocupações irregulares para fins de moradia elucidam o conflito fundiário, por meio da ocupação de terrenos públicos ou privados.

Apesar das disputas no campo legislativo, e das conquistas sociais que resultaram em instrumentos e mecanismos para que a justiça reconheça legalmente a posse dos ocupantes, também foi visto que as decisões judiciais e as negociações entre os órgãos do Estado e sociedade civil tendem ao favorecimento do proprietário, ainda que em contradição com os termos da lei. Vimos também que o discurso do Estado sobre o combate à informalidade está em contradição com as práticas e negociações que sustentam e são sustentadas por diferentes formas de ilegalidade.

Portanto, a análise do papel do Estado na concepção e execução de programas habitacionais não pode ser realizada apenas a partir do conteúdo da legislação ou da estrutura organizacional das instituições, é necessária uma análise das práticas que evidencie essas contradições e que permita enxergar além da dicotomia formalinformal.

\section{O governo das margens: compreender as práticas para compreender o Estado}

Segundo Foucault (1998, p.369), "o Estado é uma prática":

O Estado não pode ser dissociado do conjunto das práticas que fizeram efetivamente que ele se tomasse uma maneira de governar, uma maneira de agir, uma maneira também de se relacionar com o governo". 
Assim, para a análise das práticas do Estado, recorro à teoria do governo das margens de Das e Poole (2004), sendo as margens esses locais onde o Estado está constantemente redefinindo seus modos de governar e legislar, redesenhando as gramáticas da biopolítica. Desse modo, considerando que os programas habitacionais em suas diferentes etapas e formas - incidem sobre a transitoriedade das formas legais, informais, irregulares e ilegais de ocupação do solo urbano, nesta pesquisa investigo como se dá este deslocamento das fronteiras entre o legal e o ilegal, como o Estado opera e quais são os campos de força inscritos nesse processo, como é feita a gestão da vida de quem habita essas margens e "navegam pelas lacunas entre a lei e sua implementação"320.

Ao sistematizar as informações sobre os programas habitacionais, percebi que o discurso sobre o combate à informalidade refere-se às iniciativas que confrontam a propriedade privada e a lógica mercadológica que dita as regras sobre a ocupação do solo urbano. Ao mesmo tempo em que condena essas ocupações, promove deslocamentos de grupos para outras áreas, criando novas situações de informalidade. Estes ciclos são sustentados e legitimados por discursos e documentos oficiais que mascaram a ilegalidade das práticas do Estado.

Portanto, o aprofundamento deste modo de operar do Estado junto com a análise dos discursos permite compreender como se constituem essas margens por meio da ação do Estado, e não pela ausência do Estado. Desse modo, como mostram Das e Poole (2008, p.35), este "caráter indeterminado das margens" possibilita "quebrar e abrir a solidez geralmente atribuída ao estado".

A suposta transição para uma situação determinada de legalidade conferida pela regularização fundiária significa a "conversão em sujeitos de estado" daqueles que foram enquadrados em novas categorizações agora admitidas pelo mercado. Ao mesmo tempo, observo ainda que sair do fundo de vale ou da área particular "invadida" não significa sair da ilegalidade, mas se trata do governo dos corpos, a mobilidade dos corpos

\footnotetext{
${ }^{320}$ Das (2004, p.241, tradução da autora).
} 
acionada para gerir o território em benefício da propriedade privada. Trata-se de um manejamento da população mais vulnerável que se encontra nessas margens.

Para as autoras, alguns conceitos são fundamentais para a análise do estado nas margens: racionalidade, mágica, legibilidade, legitimidade, vulnerabilidade da ação e vulnerabilidade do enunciado. Para efeito de ordem, a racionalidade administrativa e hierárquica que aparentemente provém de aparatos políticos e reguladores de um Estado burocrático centralizado, faz emergir uma legitimidade associada aos efeitos das práticas estatais, como resultado dessa demarcação de limites no âmbito da racionalidade burocrática do direito. É isso que torna possível que a violência praticada pelo estado seja considerada legítima. Portanto, a "relação entre violência e as funções ordenadoras do estado é a chave para o problema das margens" ${ }^{321}$.

Das e Poole (2004) definem três conceitos de margens por meio dos quais procuro desenvolver a análise das práticas descritas nos capítulos anteriores: a margem como periferia, a margem como a (i)legibilidade do Estado, e margem como o espaço entre os corpos, a lei e a disciplina.

\section{Margem como periferia}

Este conceito trata dos locais onde aparentemente não há Estado, onde não há infraestrutura básica, onde a informalidade permeia todas as esferas da vida, onde estão as pessoas consideradas "insuficientemente sociabilizadas nos marcos da lei"322.

As etnografias 323 mostram como o Estado procura "manejar" e "pacificar" essas populações, tanto através da força como através da pedagogia da conversão tentando transformar esses "sujeitos rebeldes" em sujeitos legais de estado.

\footnotetext{
${ }^{321}$ Das e Poole (2004, p. 06).

322 Das e Poole (2004, p.9).

${ }^{323}$ O livro "Antropology in the Margins of the State" de Das e Poole (2004) traz um conjunto de etnografias que têm em comum análises das margens do Estado, nesse sentido amplo do termo que as autoras procuram definir e evidenciar.
} 
As ocupações irregulares são uma forma de resistência, que pode ser emergencial - casos de despejos, desemprego -, ou programada - com a finalidade de se manifestar para pressionar a Cohab-LD e forçar um atendimento. As respostas para este tipo de manifestação nos permitem analisar o governo desses territórios em que aparentemente o Estado não está presente, ou onde o Estado se faz presente pela aparente ausência e, assim, se isenta das responsabilidades sobre a precariedade e a vulnerabilidade dessa população.

O que se observa nessas áreas é o silêncio por parte do Estado, e a consequente invisibilidade das demandas e dos direitos. Isso pode ser notado nas famílias que são deixadas (sobre)vivendo por 40 anos em um fundo de vale, de forma precária, completamente "à margem" do "desenvolvimento" urbano, da ampliação da infraestrutura e dos serviços públicos. Portanto, nessas formas o Estado se faz ausente, mas, de fato, nunca está ausente. Isso reforça a visão de Das (2004, p. 241) de que nessas margens "o estado e sua governamentabilidade é construída por meio de contatos esporádicos e intermitentes, muito mais do que um sistema panóptico de vigilância eficiente" e constante.

O Estado se faz ausente pelo argumento de que a irregularidade da ocupação impossibilita a implantação de infraestrutura e qualquer outra melhoria na condição da ocupação. Desse modo, o Estado se exime da responsabilidade sobre a segurança dos moradores e a constatação da vulnerabilidade das famílias que aparece nos documentos não faz um contrapeso à situação da irregularidade da posse. Ao mesmo tempo, está presente constantemente no medo e nas ameaças da reintegração de posse, nos cadastros esporádicos que suscitam especulações sobre um possível atendimento, em uma mistura de esperança e medo verificados nas entrevistas com moradores do Fundo de Vale do Córrego Sem Dúvida.

Todas as ocupações irregulares, assim que a Cohab-LD é informada da sua existência, têm as casas numeradas pela Companhia, deixando a marca da presença do Estado, mesmo que essa informação não vá ser utilizada. 
A violência simbólica está presente na ameaça constante por saber que está vivendo de forma irregular, já que nas visitas de campo esta é a fala recorrente da Cohab-LD aos moradores. Esta ameaça impede essas pessoas de elaborar planos, limita os investimentos no conforto e na qualidade de vida pelo medo de "perder" aquele investimento, mantendo-se na precariedade pela insegurança. Somam-se a isso os dados imprecisos, sempre sem saber os números exatos, tão imprecisos que até os funcionários da Cohab-LD que lidam com isto todos os dias levaram um "susto" - citando um dos primeiros levantamentos sistematizados realizado em 2002 - com a falta de sistematização que leva a visões e ações pontuais, invisibilizando inclusive a totalidade do problema da habitação em Londrina. Quando não se conhece o problema, a construção do falso problema é consentida.

A condição de irregularidade é a justificativa para o uso da força - sem considerar as abordagens policiais nessas áreas com o argumento do combate ao tráfico de drogas - nas reintegrações de posse violentas, imposições dos termos de negociação garantidos graças ao monopólio da violência física. O uso da força nas mediações nessas áreas é evidente na primeira gestão da Cohab-LD, visto nos relatos do primeiro presidente da Cohab-LD que autorizou a queima de barracos durante uma desocupação.

O uso da violência também está presente nas negociações que mascaram a coação, as chantagens, a pressuposta visibilidade dada ao problema da moradia, que resulta em soluções precárias e que não visam a superação das condições de vulnerabilidade. As ações mantêm o conflito apaziguado conduzindo para uma solução que fortalece a ação governamental, mas, ao mesmo tempo, deixa a impressão que uma negociação está em curso. Isso foi visto no caso do Flores do Campo, quando as reuniões são desmarcadas, quando a proposta não é apresentada, ou quando o número de unidades proposto é insuficiente pois daria para atender apenas metade das famílias.

O atendimento fragmentado das ocupações resulta na desmobilização, pois cada ocupação cria o seu mecanismo de negociação, fragmentando o problema da moradia. Isso mantém cada movimento de ocupação isolado. O uso frequente da expressão "Passar na frente da fila da Cohab" ainda procura colocar um movimento contra o outro. 
A possibilidade do atendimento, mesmo que ele não se concretize, apazigua o conflito fundiário urbano, usando uma imagem de Estado incapaz, Estado despossuído, Estado limitado. O Estado, na figura da Cohab-LD, parece fazer alguma coisa, mas é incompetente. Desse modo, o atendimento é utilizado para pacificar, mas como não pode dar força, apenas desmobilizar, mantém as condições de precariedade.

O discurso usado para justificar o não-atendimento dos ocupantes do Flores do Campo e, depois, para justificar o atendimento precário, ou provisório, coloca a ocupação como uma tentativa de furar fila e, assim, prejudicar os "bons pobres" que estão aguardando a vez de serem atendidos residindo em casas de parentes, oscilando entre fundos de vale e casas de aluguel.

Outras medidas são usadas para criminalizar as ocupações, e isso ocorreu em situações em que o movimento tomou proporções constrangedoras para a administração pública e perdeu-se a capacidade de invisibilizar e pacificar. Assim, o Estado que representa a "figura da lei" elaborou um projeto de lei ${ }^{324}$ para criminalizar de fato as ocupações em uma medida disciplinadora declarada, desenhando, dessa forma, a linha que diferencia os "sujeitos rebeldes" dos "sujeitos legais".

Entendo que o "manejo" de que tratam Das e Poole (2004) pode ser associado às práticas das remoções de favela, porém tiveram objetivos, formas e resultados diferentes ao longo do tempo. É possível dizer que o "manejo" dessas áreas foi uma forma de "pacificá-las". Quando as ocupações ocorreram para pressionar a Cohab-LD pelo atendimento e foram "atendidas" por meio de remoções para terrenos da CohabLD, não só foi uma forma de controlar o conflito fundiário, mas foi, sobretudo, uma simulação de um atendimento em um viés populista. Outra forma de pacificação, foram as remoções de áreas privada para terrenos da Cohab-LD, em lugar do enfrentamento típico das reintegrações de posse. Em todos os casos de remoção, o que marca a diferença entre o atendimento de fato e o "manejo" é a sustentação de precariedade

\footnotetext{
${ }^{324}$ O Projeto de Lei foi aprovado como emenda à Lei Orgânica do Município no 56, de 17/10/2018. O texto proíbe a participação de famílias que se envolverem em ocupações irregulares em programas habitacionais. Sobre o posicionamento dos vereadores e da Cohab-LD, ver reportagem Folha de Londrina (2018) disponível em: https://www.folhadelondrina.com.br/politica/camara-aprova-projeto-que-coibeacoes-de-quem-ocupa-areas-publicas-1014483.html. Acesso em: 31/10/2019.
} 
nas áreas de destino, resultando em uma nova favela sem o "problema" fundiário. Assim, após o "atendimento", começam novas lutas, novas vulnerabilidades em outro local.

Margem como (i)legibilidade do Estado

Este conceito de margem está relacionado à documentação por meio da qual o Estado se faz legível para a população. Porém, para as autoras, esta não é uma legibilidade real, os documentos, as estatísticas, tudo que possibilita a classificação e o controle sobre a população e sobre o território não permitem, em verdade, ler o Estado. Trata-se, portanto, da ilegibilidade do Estado, das suas práticas, discursos e documentos ${ }^{325}$.

Esta documentação que, de certa forma, representa o Estado, ou representa suas ações, existe para consolidação do controle estatal sobre os sujeitos, as populações, os territórios, a vida (Das e Poole, 2004, p.9, tradução da autora). Portanto, “o estado está ao mesmo tempo sendo experimentado e desconstruído mediante a ilegibilidade de suas próprias práticas, documentos e palavras"326.

Assim, a respeito deste conceito de margem, interessa investigar como o Estado se mantém ilegível ou se faz legível por meio da legislação, da documentação e da estrutura hierarquizada que representa as instituições do Estado. Das (2004) chama de "assinatura do estado" todas essas formas como o Estado se faz presente para a comunidade.

O conceito de assinatura é importante para compreender a presença do estado na vida da comunidade, tanto como portador de regras e

325 Das (2004).

${ }^{326}$ Das e Poole (2004, p.10, tradução da autora). 
regulação e como presença 'espectral' materializada nos documentos ${ }^{327}$.

Nos atendimentos, a Cohab-LD realiza um cadastro que necessita da apresentação de um conjunto de documentos que não necessariamente existem - como os casos de comprovação do local de moradia quando não se tem um endereço - e a busca por documentos e a análise desses documentos que dirão quem está apto para ter seus direitos garantidos, como forma de categorização e enquadramento do públicoalvo.

Nessa lógica, são realizadas as mobilizações em torno da coleta de documentos, que não são utilizados e que não dizem nada sobre o cotidiano das pessoas, mas que são condições para provarem que se enquadram naquele conjunto de critérios estabelecidos pelo Estado. Assim, os documentos são a forma como o indivíduo será lido. Junto com os critérios surgem as formas de burlar os critérios, como ocultar um relacionamento estável para se enquadrar como "mãe chefe de família".

Ao mesmo tempo que os documentos são numerosos, dizem pouco sobre a realidade. São produzidos e utilizados sem sincronia entre os setores e são imprecisos e não garante a compreensão da totalidade da demanda por moradia ou das condições de vulnerabilidade dos residentes das ocupações. Só se toma conhecimento da história dos assentamentos quando se registra nos documentos fatos que são narrados sob a perspectiva de cada administração, resultando na criação de diferentes versões da mesma história. As incoerências entre as versões são admitidas, pois o Estado tem o pressuposto da legitimidade. A divisão dos setores da Cohab-LD é fragmentada, por isso os documentos também são produzidos e coletados de forma fragmentada, criando um "campo cego" com relação à questão da moradia.

Cada família cadastrada no ato do atendimento recebe uma ficha de "cliente". Às fichas são anexados os documentos coletados e o relatório social que comprova o enquadramento nos critérios. Considerando o exemplo dos casos das remoções para o

${ }^{327}$ Das (2004 p.250) 
Residencial Vista Bela, o critério para priorizar "moradores de áreas de risco" inventado pela Cohab-LD serviu para justificar as remoções.

Neste aspecto da legibilidade do Estado vinculada à documentação exigida e fornecida pelo Estado, o papel do Registro de Imóveis parece crucial. O título resultante do Registro de Imóveis é a garantia do direito de propriedade assegurado por meio de um documento. A "assinatura do Estado" se materializa na análise, carimbos e assinatura que dão o pressuposto da segurança jurídica, garantindo a legitimidade conferida pela assinatura do Estado. Todas as certidões, ofícios, aprovações e registros formam essa constelação de documentos que dão legibilidade a um processo cheio de "dobras". Quem concentra esse poder, quem assina, é o Cartório de Registro de Imóveis, que por estar "flutuando" entre o público e o privado, condiciona também o papel do Estado que deve arcar com todos os custos desses documentos.

Dessa forma, o Cartório de Registro de Imóveis aparece sustentado por um mercado da documentação. Também é o agente que possui o monopólio da legitimidade, resultado desse diferencial do cartório brasileiro que "analisa" o documento antes do registro "impedindo" falsificações.

Como consequência dessa lógica de legitimidade do Estado, aparecem os casos de pessoas que procuram burlar o sistema para comprovar uma renda menor, para se enquadrarem nos critérios de prioridades, para conseguir mais de uma casa que pode servir de renda de aluguel, tudo isso considerado ilegítimo. Porém, quando o Estado busca declarações para comprovação de moradia no local que não são considerados documentos oficiais, estes passam a ser considerados oficiais justamente por essa capacidade do Estado de conferir legitimidade mesmo em situações de informalidade.

Desse modo, a arquitetura dos programas e a constelação de documentos são forjadas para conferir legitimidade ao "estado de exceção" que possibilita reconfigurar, redesenhar a linha da legalidade, enquanto o Estado atua diretamente nesta "zona indeterminada" formada pelos deslocamentos de critérios.

Nesse sentido, ao mesmo tempo que a Cohab-LD concentra um conjunto de documentos que garantem a identidade, estas identidades são suprimidas pelos 
critérios generalizantes de enquadramento na política: "zero a três salários mínimos", "interesse social", "assentamento consolidado", "mãe chefe de família". Todos os critérios que vão tratar da oportunidade de se tornar cliente da Cohab-LD. Da mesma forma, o NIS - Número de cadastro social - que é o cadastro que torna a população de baixa renda legível ao Estado, que concentra o histórico de atendimento de cada família, é o que vai caracterizar aquele que se torna beneficiário. Essas são as formas de tornar as pessoas legíveis para elas mesmas.

Assim, os documentos (e o processo de coleta) consistem na forma como o Estado ao mesmo tempo se faz ilegível, mas se faz presente e "penetrante na vida diária". A documentação simboliza uma vitória, fruto da negociação com o Estado. Receber a documentação significa ser atendido, mesmo que da forma mais precária.

Dessa maneira, "o estado está presente na forma de rumor - sua assinatura é lida em todo lugar"328. Nesta mesma linha Bourdieu (2014, p.83) vai afirmar que "os juristas são os mestres da linguagem". O Registro de Imóveis consiste na garantia do direito de propriedade, e promoveu historicamente uma espécie de teatralização necessária para que a propriedade pudesse ser instituída como mercadoria, para possibilitar a desvinculação do "direito à terra" da "sua efetiva utilização". Portanto, segundo Bourdieu (2014, p.61), o

Conjunto de instituições que chamamos 'o Estado' deve teatralizar o oficial e o universal, deve dar o espetáculo do respeito público pelas verdades públicas, do respeito público pelas verdades oficiais em que a totalidade da sociedade supostamente deve se reconhecer. Deve dar o espetáculo do universal, aquilo sobre o que todos, em última análise, estão de acordo, aquilo sobre o que não pode haver desacordo porque está inscrito na ordem social em determinado momento de tempo.

O Estado elabora um conjunto de leis complexo e massivo, mas não precisa utilizar. Decreta a exceção quando Ihe convém e modifica as leis quando convém. A aplicação da lei não é nem um pouco pragmática. Portanto, a ilegibilidade das regras do

${ }^{328}$ Das (2004, p.244). 
Estado cria uma margem quanto à forma como se executa a lei, por exemplo, promovendo as remoções irregularmente.

Considerando o cotidiano de negociações, as remoções para o PMCMV em Londrina foram promovidas de maneira irregular perante as regras da Caixa Econômica Federal. Para legitimar estas práticas as anotações nos documentos - prioridade/mãe chefe de família - e as fotos que se constituem "provas" da situação de risco - noção de risco que foi delineada também para legitimar as remoções. Estes documentos, assim como Das (2004, p. 240) descreve sobre a política habitacional de Nova Delhi, "dão áurea de uma operação legal (...) em outras palavras, a vida dos documentos continua como se fosse "negócios como de costume'".

O procedimento da regularização fundiária, como visto, também está centrado na documentação. São certidões de diferentes órgãos "necessárias" para a aprovação do "loteamento". Depois de aprovado, a documentação das famílias é analisada. Abertura das matrículas, o "carimbo" e a "assinatura" do cartorário, e a emissão do título, é esse conjunto de documentações que resulta em um novo documento - o título de propriedade - que vai caracterizar este programa habitacional.

O fato de o Estado não conseguir esconder as negociações corruptas e as ilegalidades que ele realiza e se envolve pode ser considerada uma fragilidade do Estado $^{329}$. Mas, para Das (2004), a vulnerabilidade e o poder não são opostos, e são dois aspectos do Estado que permitem explicar como essas fragilidades não comprometem seu poder: o "modo racional" e o "modo mágico" de existência do Estado. O Estado, enquanto uma entidade racional, é constituído por regras e regulações estruturadas pela legislação e nas instituições hierarquizadas que fazem parte dele. Por outro lado, o modo "mágico" de existência se sustenta pelas forças que não são transparentes, que representam o perigo e a obscuridade do poder estatal, a face do Estado que não é acessada pela população.

Pela articulação dessas duas características fundamentais do Estado é que este se torna ilegível, porém legítimo. E essa ilegibilidade das regras do Estado cria uma

${ }^{329}$ Das (2004). 
margem, onde os modos de governo estão em constante redefinição. Essas margens são constituídas por práticas, lugares e linguagens, são margens sociais e territoriais onde limites entre legal e ilegal, centro e periferia, público e privado são fluidos e indefinidos ${ }^{330}$.

Margem como espaço entre os corpos, a lei e a disciplina:

Este conceito de margem trata das formas como "o poder estende seus tentáculos pelas capilaridades do social”331. Aqui as autoras se referem ao conceito de biopolítica de Foucault, em que o poder não é exercido somente sobre os territórios, é exercido sobre os corpos, realizando o governo da vida.

O poder tem por objetivo, portanto, o governo das populações, que só é possível se os corpos forem governáveis. Essa é a ideia que dá origem à noção de poder disciplinar necessário para tornar os corpos dóceis e, assim, governáveis. Para isso, o poder disciplinar concentra quatro características básicas: a distribuição dos corpos no espaço, o controle do tempo, a vigilância e a produção de um saber ${ }^{332}$. O poder disciplinar seria, portanto, o mecanismo pelo qual o Estado opera sobre a subjetividade, como exerce o governo sobre a vida, ou o que Foucault chama de biopolítica.

Nesse sentido, o Estado governa os corpos para governar o território, portanto é sobre os corpos biopolíticos que o poder é exercido. Por isso, afirmam Das e Poole (2004, p.10, tradução da autora) que nas margens é possível observar a "colonização da lei pelas disciplinas". Nas margens, não são as leis que ditam as regras, é a disciplina. A disciplina tem por objetivo submeter os corpos para transformá-los em corpos úteis e governáveis, ou seja, em corpos dóceis que podem ser "utilizados", "transformados" e "aperfeiçoados"333. Essa sujeição dos corpos visa exercer sobre eles "uma coerção sem

\footnotetext{
${ }^{330}$ Das (2004).

${ }^{331}$ Das e Poole (2004, p.10, tradução da autora).

${ }^{332}$ Foucault (2014).

${ }^{333}$ Foucault (2014, p. 134).
} 
folga" ${ }^{334}$. São esses métodos, essas táticas de controle sobre os corpos, que dissociam o poder dos corpos, que Foucault chama de "disciplinas" e que são retomadas por Das e Poole (2004) como outro conceito de margem.

O momento histórico das disciplinas é o momento em que nasce uma arte do corpo humano, que visa não unicamente o aumento das suas habilidades, nem tampouco aprofundar sua sujeição, mas a formação de uma relação que no mesmo mecanismo o torna tanto mais obediente quanto é mais útil, e inversamente. Forma-se então uma política das coerções que são um trabalho sobre o corpo, uma manipulação calculada de seus elementos, de seus gestos, de seus comportamentos. $O$ corpo humano entra numa maquinaria de poder que o esquadrinha, o desarticula, o recompõe. Uma 'anatomia política', que é também igualmente uma 'mecânica do poder', está nascendo; ela define como se pode ter o domínio sobre o corpo dos outros, não simplesmente para que façam o que se quer, mas para que operem como se quer, com as técnicas, segundo a rapidez e a eficácia que se determina. A disciplina fabrica assim corpos submissos e exercitados, corpos "dóceis" 335 .

Os "corpos dóceis" são aqueles que ocupam para serem atendidos, para serem vistos, os sujeitos criados pelos dispositivos constituídos ao longo do tempo. Uma manifestação pacífica que não confronta a propriedade na medida em que ocupa a terra pública que não é de propriedade da Cohab-LD nem é de interesse do mercado, uma vez que é imprópria para urbanização. Consiste em uma forma de ser notado, e vive na incerteza e na esperança de que o atendimento irá chegar. Para estes, a Cohab-LD representa a assistência, a ajuda, que vai tirá-los da situação de risco e dar a oportunidade de serem atendidos por algum programa habitacional.

Por outro lado, os "corpos rebeldes" são aqueles que se organizam e dão visibilidade ao conflito em torno da propriedade. Ocupam terrenos particulares, conseguem "ler" o Estado na ilegibilidade, conhecem as leis e os direitos e trazem tensão às negociações, simbolizam resistência e reivindicam. Diante destes a máscara da assistência cai, e as estratégias de criminalização e isolamento são acionadas. Nas

${ }^{334}$ Foucault (2014, p. 134).

335 Foucault (2014, p.135). 
negociações, a força do Estado vai sendo revelada pela verticalidade das propostas. São os "invasores" que tentam "passar à frente" dos demais, que tentam desestabilizar o trabalho da Cohab-LD e da Caixa Econômica, os culpados por deixar Londrina sem recursos para a política habitacional. A divulgação deste tipo de fala procura colocar em evidência aqueles corpos em uma situação de "vida nua", do bandido, do invasor. A categorização também é outro efeito da disciplina. Quem se enquadra em qual categoria, quem é prioridade. Coloca em contraposição uma moradora solteira da Ocupação Flores do Campo e uma mãe chefe-de-família moradora de um fundo de vale.

O objeto da reintegração de posse, as ações policiais e as ameaças são responsáveis pela instauração do medo no cotidiano, que é, portanto, resultado de programas coercitivos do Estado. A situação de aparente vigilância constante nas ocupações por meio da numeração das casas e visitas esporádicas também disciplinam. Diferentemente da vigilância constante do "panoptismo"336, como colocam Das e Poole (2004), a presença do Estado é percebida de diferentes formas, mas as visitas sem aviso prévio criam uma situação de tensão constante. A violência simbólica é, portanto, disciplinadora e resultante dessa suposta vigilância combinada com a angústia entre ser atendido ou enfrentar uma reintegração de posse. Além da vigilância, então, a disciplina também utiliza a punição como medida disciplinadora. Como coloca Foucault (2014), trata-se do par vigiar e punir.

A reprodução dessas práticas, o "atendimento" das famílias residentes em fundos de vale que são levadas para terrenos da Cohab-LD nos chamados "assentamentos urbanos" em contraposição às ocupações em áreas particulares que resultam em confrontos violentos disciplinaram os ocupantes no sentido de que as chances de atendimento para quem ocupa um fundo de vale é maior e menos violenta do que para as ocupações de áreas particulares. Esta medida que, ao mesmo tempo, teve como objetivo dar continuidade a uma sequência de atendimentos em uma gestão populista, e de promover o controle sobre o conflito fundiário, disciplinou e constituiu

${ }^{336}$ Foucault (2014). 
sujeitos. A disciplina nesses atendimentos consiste, portanto, em converter os favelados considerados "bons pobres" em "sujeitos de estado", em proprietários.

\section{Governamentalidade e o poder de Estado}

Dentro dessa perspectiva, o papel do Estado está relacionado ao que Foucault chama de governamentalidade. Esta seria uma forma de governar, ou uma forma de exercício do poder bastante específica que se dá por meio de "instituições, procedimentos, análises e reflexões, cálculos e táticas" e que visa o governo da população $0^{337}$. Essa governamentalidade levou à constituição de aparelhos de governo e formas de saber que consideram as características naturais dos sujeitos não para tentar inibi-las, mas para incorporá-las de forma que seja possível fazer os indivíduos agirem por vontade própria conforme os interesses do Estado ${ }^{338}$.

Para isso, a governamentalidade vai ser responsável pela constituição de um sujeito, que "é sujeitado em redes contínuas de obediência [e que é] subjetivado pela extração de verdade que lhe é imposta" ${ }^{339}$. Desse modo, por meio da constituição de um saber, de uma verdade imposta aos sujeitos ao mesmo tempo em que são disciplinados, suas vontades são delineadas por parâmetros de normalidade definidos artificialmente pelo Estado, tendo como principal objetivo a propagação de uma racionalidade econômica e a constituição de mercado.

É esse modo de governar que, para Foucault, vai se tornar o paradigma do Estado neoliberal. Portanto, trata-se de um tipo de poder que não pressupõe a imposição do poder de forma vertical pelo Estado, mas como uma prática social que se funda a partir de práticas capilares que se constituem como uma rede no corpo social. Por isso, as formas de resistência surgem inerentes à constituição do poder, e dão os contornos à forma como o poder opera.

\footnotetext{
${ }^{337}$ Foucault (1977, P.171).

${ }^{338}$ Foucault (2008).

${ }^{339}$ Foucault (2008, p.243).
} 
Para compreender "como" o poder é exercido, Foucault (1998) propõe o estudo a partir do direito, que desenha "limites" à execução do poder, e das "verdades" que são produzidas pela realização do poder e que, ao mesmo tempo, passam a legitimar sua reprodução. Propõe, portanto, a análise da tríade "poder, direito e verdade". Sua proposta é analisar não somente os efeitos do exercício do poder, mas, principalmente, a mecânica por meio da qual ele é exercido.

A ideia de verdade está intimamente ligada à produção do saber, à forma como os "efeitos de poder circulam entre os enunciados científicos" 340 . Por isso, a análise do discurso se torna importante para examinar como são produzidos os efeitos de verdade, sem a rigidez da análise que busca verificar a veracidade ou falsidade do discurso. Procura-se compreender como estes saberes produzidos fazem parte do exercício do poder $^{341}$.

Operar por meio da construção de verdades e de discursos é o que garante a manutenção do poder por delinear consensos em torno dessas verdades. Uma ideia de poder vertical, imposta, levaria necessariamente à organização de formas de resistência por parte daqueles que sofrem os efeitos da dominação no cotidiano ${ }^{342}$. Mas se são construídas verdades, disseminadas por discursos que alcançam a subjetividade, os efeitos de poder passam a ser reproduzidos dentro e pelo próprio corpo social. Desse modo, as manifestações de resistência vão sendo desenhadas dentro dos limites instituídos pelo controle dos saberes. Assim, o poder não se reproduz pela força, mas pelo consenso parcialmente camuflado.

Sem desconsiderar as diferenças fundamentais entre os autores ${ }^{343}$, aqui, utilizo os conceitos de "monopólio da violência simbólica" e de "integração lógica" de Bourdieu (2014) para ajudar a aprofundar neste tema.

\footnotetext{
${ }^{340}$ Foucault (1998, p.05).

341 Desse modo, nos aproximamos do que Foucault define como genealogia: "É isto que eu chamaria de genealogia, isto é, uma forma de história que dê conta da constituição de saberes, dos discursos, dos domínios do objeto, etc., sem ter que se referir a um sujeito, seja ele transcendente com relação ao campo dos acontecimentos, seja perseguindo sua identidade vazia ao longo da história" (Foucault, 1998, p.07). 342 Foucault (2004).

343 É preciso considerar para a análise que Foucault e Bourdieu tratam de momentos diferentes do neoliberalismo, apesar das convergências em relação a algumas questões. Enquanto Foucault analisa as
} 
Lembrar que os sistemas simbólicos não são simplesmente formas cognitivas, mas também estruturas coerentes é dar-se o meio de compreender um dos aspectos mais ocultos, mais difíceis de capturar da eficácia simbólica, notadamente da ordem simbólica do Estado: o efeito de coerência, de quase-sistematicidade, de falsasistematicidade. Um dos princípios da eficácia simbólica de tudo o que o Estado produz e codifica - sistema escolar, código de trânsito, código linguístico, gramática, etc. - reside nessas espécies de coerências ou de falsas-coerências, nessas racionalidades ou falsas-racionalidades. Os sistemas simbólicos exercem um poder estruturante porque são estruturados, e um poder de imposição simbólica, de extorsão da crença porque não são constituídos ao acaso. ${ }^{344}$.

Segundo Bourdieu (2014, p.30), o Estado pode ser definido como o possuidor da violência física e simbólica legítima ou, ainda, é o detentor do "monopólio da violência simbólica legítima, na medida em que o monopólio da violência simbólica é a condição da posse do exercício do monopólio da própria violência física".

O Estado também é o fundamento da integração da lógica e da moral do mundo social, de modo com que os agentes do mundo social tenham as mesmas "percepções lógicas", por meio das mesmas "categorias de pensamento, de percepção, de construção da realidade". Portanto, "a integração moral é o acordo sobre um certo número de valores" ${ }^{345}$. A proposta de integrar por meio do discurso na construção de verdades inibe o questionamento e outros modos de interpretação daquela realidade. A formação de um consenso em torno das práticas de Estado que sustentam determinada forma de poder.

A disciplina e a constituição de verdades que operam na constituição dos sujeitos têm como objetivo criar sujeitos dóceis e produtivos - e transformar revoltosos em público-alvo, favelados em proprietários - de forma a minimizar conflitos, criar e ampliar mercados. Portanto, "para que o próprio conflito sobre o mundo social seja possível, é

transformações que passam as práticas de governo, Bourdieu analisa os efeitos dessas práticas sobre o corpo social. Apesar das diferenças na análise e abordagem dos autores, ambos vão apontar como papel do Estado "instaurar situações de mercado" (Foucault), de adaptar o comportamento dos indivíduos à racionalidade neoliberal (Foucault). O Estado passa a ter como função e ação constituir mercado e o campo econômico sujeita os demais campos à razão de mercado, já que a ciência econômica passa a dominar o campo do saber. (Laval, 2008).

344 Bourdieu (2014, p.34).

${ }^{345}$ Bourdieu (2014, p.31). 
preciso haver uma espécie de acordo sobre os terrenos do desacordo e sobre os modos de expressão do desacordo"346.

É disso que trata a dinâmica das formas de negociação sobre as remoções e as possibilidades de regularização fundiária. Quais os tipos de manifestação e contestação da situação da moradia que serão toleradas em uma perspectiva de manutenção da ordem das coisas. Quais são os limites toleráveis dos "terrenos do desacordo" sobre o conflito fundiário em Londrina.

O que se observa em relação ao conflito fundiário, é a submissão às normas da Cohab-LD, dentro dos limites definidos aos atos de resistência. Isso porque "o efeito mais paradoxal do Estado é o da crença, de submissão generalizada ao Estado." ${ }^{347}$. Esse poder de Estado, de manter a ordem sem a necessidade de manter uma coerção permanente é garantida, sobretudo, por deter o "monopólio da violência simbólica". Bourdieu (2014) defende que o Estado, além do monopólio da força física, por ser o detentor do monopólio da violência simbólica, opera criando subjetividades e garantindo a obediência mesmo na aparente ausência do Estado.

O dominado conhece e reconhece: $o$ ato de obediência supõe um ato de conhecimento, que é ao mesmo tempo um ato de reconhecimento. Em reconhecimento há, evidentemente, 'conhecimento': isso quer dizer que quem se submete obedece, dobra-se a uma ordem ou a uma disciplina, opera uma ação cognitiva ${ }^{348}$.

A noção de "operar uma ação cognitiva" parece central, tanto para Bourdieu como para Foucault, para que a obediência seja mantida sem a necessidade do uso da força. Bourdieu questiona se a capacidade do Estado de "impor-se tão facilmente" não estaria relacionada ao fato de que ele está em condições de impor as estruturas cognitivas a partir das quais ele é interpretado. Portanto,

\footnotetext{
${ }^{346}$ Bourdieu (2014, p.31).

${ }^{347}$ Bourdieu (2014, p.228).

348 Bourdieu (2014, P.226).
} 
A invenção da nova lógica estatal é o produto de um trabalho coletivo de construção desse conjunto de realidades sociais totalmente novas que são as instituições participantes da ideia do público. $O$ corpo dos agentes que, como os juristas, têm interesses comuns com a lógica estatal, mais 'universal' (ou universalista) em seu princípio do que a lógica dinástica, representa um papel determinante na construção da coisa pública e do espaço (o campo burocrático) em que se inventam as instituições burocráticas (o escritório, o secretário, a assinatura, o selo, o decreto de nomeação, o certificado, o atestado, o registro, etc.). ${ }^{349}$

Esse processo levou à constituição da autoridade burocrática "baseada na delegação limitada entre agentes se garantindo e se controlando mutuamente" 350 . Desse modo, as instituições são resultado de uma construção coletiva, e respondem à lei da mecânica dos interesses particulares no interior da população 351 .

\section{A mecânica do dispositivo}

(...) como funcionam as coisas ao nível do processo de sujeição ou dos processos contínuos e ininterruptos que sujeitam os corpos, dirigem os gestos, regem os comportamentos, etc. ${ }^{352}$.

Para entender o processo de sujeição dos corpos, das ações, dos comportamentos a esses interesses no funcionamento do campo burocrático, é necessário compreender como o poder é exercido sobre os sujeitos; é necessário compreender como operam os dispositivos de poder.

A concepção do dispositivo de poder responde a uma tecnologia de poder que visa o governo dos corpos e da população. Porém, como constata Foucault (2008), não se trata mais de um governo soberano que exerce o poder por meio da força e da imposição, mas para que essa massa populacional seja governável da forma mais eficiente possível e quase isenta de revoltas, o poder passa a ser exercido pela suposta

\footnotetext{
349 Bourdieu (2014, P.487).

${ }^{350}$ Bourdieu (2014, P.487).

${ }^{351}$ Foucault (2008, p.473).

${ }^{352}$ Foucault (1998, p. 102).
} 
liberdade dos indivíduos, que se tornam governáveis na medida em que este poder cria indivíduos e delineia um campo de desejos.

Segundo Foucault (2008) é justamente essa "naturalidade do desejo" próprio da população que é o canal pelo qual penetra essa tecnologia de governo. O controle dos desejos é o que garante o governo da população, fazendo com que suas escolhas reflitam os interesses do Estado. Para isso, são constituídos dispositivos responsáveis por fazer esse poder penetrar no cotidiano criando subjetividades. Ainda, diferentemente da soberania, que se exerce sobre um território, a disciplina é exercida sobre os corpos, enquanto a segurança é exercida sobre a população. Por isso, cabe fazer a diferenciação entre dois tipos gerais de dispositivos descritos por Foucault: os dispositivos de segurança dos dispositivos disciplinares.

Segundo Foucault (2008, p.15), as principais características dos dispositivos de segurança são: a criação de espaços de segurança; tratamento do aleatório; forma de normalização específica da segurança (que, por sua vez, é diferente da normalização disciplinar), e a correlação entre técnica de segurança e normalização da população, "ao mesmo tempo objeto e sujeito desses mecanismos de segurança".

Já a disciplina se dá sobre os corpos, mas para isso, é preciso haver a multiplicidade e um resultado que se pretende alcançar, ou seja, uma forma de administrar esta multiplicidade em prol deste objetivo. Trata-se da individualização das multiplicidades. A segurança também é baseada na multiplicidade, mas o que as difere é a forma de tratamento do espaço, pois enquanto o mecanismo da segurança utiliza a estimativa de probabilidades, por um lado evitando revoltas, e por outro, garantindo a circulação, a disciplina isola um espaço determinando um segmento específico, concentra e circunscreve um espaço onde os mecanismos de seu poder funcionarão plenamente; ela controla, limita e proíbe, enquanto o dispositivo de segurança "deixa fazer" para não deixar outras coisas acontecerem.

Junto com a lei, a segurança e a disciplina vão operacionalizando o poder sobre os indivíduos, apoiando-se na liberdade de cada um: 
Em outras palavras, a lei proíbe, a disciplina prescreve e a segurança, sem proibir nem prescrever, mas dando-se evidentemente alguns instrumentos de proibição e de prescrição, a segurança tem essencialmente por função responder a uma realidade de maneira que essa resposta anule essa realidade a que ela responde - anule, ou limite, ou freie, ou regule. Essa regulação no elemento da realidade é que é, creio eu, fundamental nos dispositivos da segurança ${ }^{353}$.

A normalização também é um conceito fundamental para Foucault. Apesar da norma poder ser codificada pela lei, Foucault mostra que as técnicas de normalização não estão necessariamente alinhadas às leis, pelo contrário, podem se desenvolver "nas margens e até mesmo na contramão de um sistema da lei" 354 .

A noção de dispositivo criada por Foucault corresponde a um conjunto heterogêneo formado por "discursos, instituições, organizações arquitetônicas, decisões regulamentares, leis, medidas administrativas, enunciados científicos, proposições filosóficas, morais, filantrópicas" e práticas que atuam em conjunto e em rede em torno de um objetivo estratégico ${ }^{355}$. Estes elementos podem ser rearranjados, reorganizados e modificados de acordo com sua "função estratégica dominante". O discurso aparece como elemento determinante, pois garante ao dispositivo acessar novos campos de racionalidade justificando, mascarando ou reinterpretando as práticas. Esse saber - resultante dos discursos - que nasce do dispositivo também passa a condicioná-lo durante sua operação. Outra característica fundamental do dispositivo é que "está sempre inscrito em um jogo de poder"356.

É isto, o dispositivo: estratégias de relações de força sustentando tipos de saber e sendo sustentado por eles ${ }^{357}$.

A articulação entre os elementos não pressupõe um planejamento prévio, em um primeiro momento, o dispositivo se constituiu como resposta para uma urgência, ou

\footnotetext{
${ }^{353}$ Foucault (2008, p.61).

${ }^{354}$ Foucault (2008, p.74).

${ }^{355}$ Foucault (1998, p. 138).

${ }^{356}$ Foucault (1998, p. 139).

${ }^{357}$ Foucault (1998, p. 139).
} 
seja, surgiu com uma "função estratégica" predominante para responder a uma urgência. Uma vez constituído, o dispositivo passa a ter uma "sobreterminação funcional", ou seja, os efeitos gerados reverberam ou contradizem outros efeitos, o que demanda um reajustamento constante ${ }^{358}$. Segundo Foucault (1998) para identificar um dispositivo ele busca os elementos que intervieram em uma determinada racionalidade.

A partir do estudo de natureza genealógica dos programas habitacionais realizados pela Cohab-LD, o chamado "desfavelamento", se tornou uma prática recorrente que perpassou programas e gestões. Essa prática foi utilizada, em um primeiro momento, como resposta a uma "emergência", quando as ocupações irregulares avançaram para terrenos particulares. A escolha das áreas a serem removidas esteve relacionada a ocupações em áreas particulares, aos recursos do BNH e ao discurso de extinção de favelas disseminado pelo Banco. Em outro momento da política municipal, o desfavelamento foi utilizado para retirar famílias que residiam em áreas de fundos de vale e levadas para terrenos da Cohab-LD, onde recomeçavam a ocupação, sem investimentos em infraestrutura e construção de unidades habitacionais, formando os "assentamentos urbanos" promovidos pela Cohab-LD.

O discurso da extinção de favelas foi propagado em documentos, no campo científico, e as justificativas das práticas oscilaram entre o valor das terras ocupadas no mercado, a preservação ambiental e condições de risco em que se encontravam as famílias. Algumas evidências mostram que, mesmo quando as remoções envolveram áreas de preservação permanente, houve influência de processos de valorização imobiliária.

O desfavelamento passou a ser sinônimo de "atendimento" pela Cohab-LD e reivindicado como solução. Justificado pelos discursos e legitimado pela legislação, tornou-se uma verdade instituída. A construção da justificativa, a existência de leis (código de posturas), a "questão" da preservação ambiental, a elaboração de documentos diagnósticos da precariedade habitacional que evocam as práticas das remoções como solução, constituíram uma verdade, um saber. Por esse motivo, mesmo

358 Foucault (1998). 
depois de superada a ideia da "extinção" de favelas marcante no discurso da década de 70 e 80 , as remoções de favelas continuam naturalizadas, sendo poucos os casos de resistência.

No contexto do Programa Minha Casa Minha Vida as remoções tornaram-se centrais na distribuição das unidades realizada pela Cohab-LD. O caso da zona leste, apontada como alvo de remoções nos diagnósticos desde o início da década de 2000, evidencia que as remoções estão relacionadas à renovação urbana desta região e, por isso, rompem com qualquer lógica territorial.

Apesar das remoções consistirem em práticas recorrentes ao longo das gestões municipais, o número de remoções e as distâncias dos deslocamentos aumentaram significativamente no PMCMV em relação aos programas anteriores, fato que está associado ao número de unidades produzidas pelo PMCMV, pela sistematização de diagnósticos ao longo da década de 2000 que priorizaram ações de remoções (relacionadas às áreas de preservação permanente) e pela higienização promovida na zona leste. Ainda, priorizou-se a desocupação de áreas particulares, porém em casos pontuais houve resistência por parte dos moradores.

O Programa de Regularização Fundiária reflete a dinâmica do dispositivo, já que grande parte das unidades regularizadas corresponde a assentamentos urbanos e conjuntos habitacionais que resultaram de remoções anteriores. Em todos os casos contemplados pelo programa, o conflito fundiário já foi resolvido em outro momento, por meio de remoções ou ocupações que resistiram às reintegrações. Neste contexto em que a regularização fundiária corresponde à titulação das famílias, este programa veio legitimar esses processos por meio da "assinatura do Estado".

O dispositivo possui instrumentos disciplinadores, mas também mecanismos de gestão da população por meio de uma aparente liberdade, e estes são acionados conforme as dinâmicas políticas e econômicas em curso. A aparente liberdade de ocupar irregularmente uma área como forma de contestação do modelo de atendimento da Cohab-LD está condicionada à escolha das áreas: áreas de interesse do mercado, ou como no caso do Flores do Campo, são acionadas a criminalização e medidas de 
repressão que elucidam as limitações da suposta liberdade; enquanto as ocupações em fundos de vale levam mais tempo para ser alvo de desocupação e, quando elas acontecem, o encaminhamento para uma solução paliativa tornou-se uma constante no processo.

São medidas disciplinadoras as condições para os atendimentos; as definições de prioridade/não prioridade; a documentação (certidões, averbação de divórcio, comprovantes, etc) para regularização fundiária; coação dos ocupantes; ocupação de terrenos da Cohab-LD que dão garantia de atendimento; desocupação violenta; demarcação das casas; visitas esporádicas, e atendimento precário/parcial; no extremo desse processo, a lei que proíbe o atendimento de famílias que participaram de ocupação. Esse é o governo pela liberdade, deixa ocupar para depois retirar.

Essa mecânica do dispositivo constituiu sujeitos de práticas, já que ocupar uma porção de um fundo de vale pode significar acesso a um atendimento. É um dispositivo disciplinador porque diferencia o "bom" e o "mau" pobre, categorizando-os em "cliente/beneficiário" ou "invasor". É um dispositivo de segurança porque "deixa fazer". Os núcleos regularizados são aqueles que passaram pela constituição do dispositivo, enquadrando-se na racionalidade dos discursos, integrados pelas verdades instituídas, que apresentam uma forma arquitetônica aceita para integração no mercado formal. 0 dispositivo visa, ao mesmo tempo, a criação e ampliação de mercado e o controle do conflito fundiário (que pode se constituir em uma barreira para o mercado). 


\section{Gestão diferencial dos ilegalismos e a propriedade privada}

No início da pesquisa, ao começar a analisar os dados sobre os programas habitacionais realizados na última década em Londrina, me chamou a atenção o fato de que tanto a produção de novas unidades habitacionais, como o programa de regularização fundiária estavam ligados às práticas do desfavelamento. Foi assim que as remoções se tornaram uma categoria importante para a análise e me levaram a olhar sob outra perspectiva a execução dos programas habitacionais em Londrina.

Buscando compreender como essa prática se consolidou sem resistência na política habitacional, realizei o estudo de caráter genealógico dos discursos, documentos e leis que historicamente embasaram e legitimaram tais práticas. A partir deste estudo e da análise dos perfis das diferentes gestões municipais, verifiquei que o desfavelamento foi utilizado de forma sistêmica, porém nem sempre realizado com base nos mesmos critérios. Utilizadas para desocupar terrenos valorizados, para "higienizar" áreas em transformação ou para sustentar campanhas populistas, as remoções de favelas não tiveram, apesar do discurso disseminado, o objetivo de extinguir as ocupações irregulares.

Não restam dúvidas de que as formas irregulares de moradia desempenham um papel na redução de salários e na precarização da mão-de-obra e que são inerentes ao modelo econômico vigente. Também por isso, a extinção de favelas e de ocupações irregulares de um modo geral não está no horizonte das políticas urbanas. Ainda, com base na pesquisa, é evidente que os ilegalismos referentes à ocupação do solo urbano não representam a ausência do Estado, mas são constantemente produzidos, legitimados e negociados pelo Estado.

Por isso, compreender a dimensão "simbólica" (Bourdieu) ou "mágica" (Das) do Estado é fundamental para se permitir olhar além das fronteiras rígidas da legalidade em que se costuma inscrever as práticas estatais. Nos permite olhar para as práticas e interpretá-las além da dicotomia legal/ilegal e, assim, compreender que são estas mesmas práticas que desenham essas fronteiras flutuantes. Dessa forma, compreender 
o Estado significa olhar por dentro dessas práticas que incidem diretamente sobre as diferentes formas dos ilegalismos urbanos.

Nesse sentido, utilizo a noção de "metacampo" de Bourdieu ${ }^{359}$ para a definição de Estado ${ }^{360}$, em que "assiste-se à constituição progressiva de um espaço diferenciado, de um conjunto de campos - campo jurídico, campo administrativo, campo intelectual, campo político propriamente dito (...) -, e cada um desses campos é o lugar de lutas [específicas]". Nessa disputa, Bourdieu reconhece que no neoliberalismo o campo econômico invade todos os outros campos ${ }^{361}$ :

Cada campo quer agir sobre esse metacampo para triunfar simultaneamente sobre os outros campos e dentro do seu campo. (...) o que se constitui é, assim, um espaço de poder diferenciado, que chamo de campo do poder. (...) creio que descrevo a gênese do campo do poder, isto é, um espaço diferenciado dentro do qual os detentores de poderes diferentes lutam para que seu poder seja o poder legítimo. Uma das implicações das lutas dentro do campo do poder é o poder sobre o Estado como metapoder capaz de agir sobre os diferentes campos $^{362}$.

Podemos considerar, portanto, que essa sujeição completa do Estado à racionalidade produtiva/econômica corresponde ao domínio do campo do poder pelo campo econômico e leva à subordinação do campo jurídico à revisão constante e à instauração de medidas de exceção para que o mercado não enfrente obstáculos para sua ampliação.

Por isso, neste momento do neoliberalismo, são as transformações econômicas que passam a ditar o momento de decretar um "estado de exceção" 363 para a

\footnotetext{
${ }^{359}$ Bourdieu (2014, p.407).

${ }^{360}$ Bourdieu também afirma que o Estado "é o princípio de organização do consentimento como adesão à ordem social, a princípios fundamentais da ordem social, e que ele é o fundamento, não necessariamente de um consenso, mas da própria existência das trocas que levam a um dissenso". (Bourdieu, 2014, p.31). Assim, consenso e dissenso são campos de atuação do Estado por meio dessas ramificações de formas de controle dos conflitos na sustentação da estrutura de poder.

361 Laval (2018).

362 Bourdieu (2014, p.407).

363 Aqui, a ideia de "estado de exceção" de Agambem pode ser interpretada pelo que ele chama de “abolição provisória da distinção entre poder legislativo, executivo e judiciário" (Agambem, 2004, p.19). Para ele não se trata do que está dentro ou fora do ordenamento jurídico, mas sobre a criação de uma
} 
reorganização das estruturas sociais e econômicas, mascarado pelo discurso da flexibilização dos marcos legais para dar mais espaço à produção e reprodução de capital.

É, portanto, a partir dessa "transitividade entre o legal e o ilegal"364 que se pode compreender como ela se conecta ao circuito de circulação de capital. No caso da regularização fundiária, se conecta com a emissão de títulos de propriedade em massa, em uma releitura da teoria de De Soto ${ }^{365}$ que foi recolocada pelo Banco Mundial, não só pela perspectiva de incluir mais áreas (até então marginais) no mercado formal, ampliando possibilidades de crédito em um processo de monetarização da pobreza, mas também como aumento do controle sobre a terra, neste momento em que o mercado - sobretudo o financeiro - passa a ter mais interesse sobre a terra como forma de garantir mais segurança a investidores e bancos. Nesse contexto, a regularização aparece associada a outras revisões nos marcos legais, como o princípio da concentração e a alienação fiduciária, redefinindo regras e garantias para os agentes que operam nos negócios imobiliários no Brasil.

\footnotetext{
"zona de indiferença em que dentro e fora não se excluem, mas se indeterminam" (Agambem, 2004, p.39).

${ }^{364}$ Telles (2005, p.505).

365 De Soto (2000) aborda a informalidade, que ele chama de "capital morto", como uma das causas para o fracasso do capitalismo nos países subdesenvolvidos e, por isso, para ele, a economia informal precisa ser englobada ao circuito formal de capital como forma de superar os obstáculos do desenvolvimento capitalista. Essa abordagem se aplica, sobretudo, à propriedade privada do solo. Por isso ele propõe a regularização fundiária em massa das extensas ocupações irregulares situadas nesses países, como forma de incluir essa população pobre no circuito de capital por meio de microempréstimos que tomariam essas unidades regularizadas como garantia. Apesar da experiência considerada fracassada no Perú, nesse sentido parece haver uma referência direta à abordagem de De Soto nos documentos do Banco Mundial, principalmente em relação ao papel da titulação dos imóveis. Quando De Soto desenvolve a ideia sobre a fixação do potencial econômico em ativos, ele exemplifica chamando a atenção para a forma como se olha para uma casa. Se focarmos no título da casa, o que veremos será o potencial econômico daquela casa, filtrando toda a confusão que pode estar relacionada aos aspectos físicos e locacionais. Assim, passamos a ver a casa não como um abrigo, que ele chama de ativo morto, mas a veremos como capital vivo. De Soto também argumenta sobre a necessidade de integrar as informações sobre as propriedades em um sistema de informação único integrado, para que as informações não fiquem dispersas, para garantir controle e criar um mercado único integrado e, assim, transformar efetivamente a propriedade em ativo.
} 
Desse modo, a política habitacional vai se redesenhando nesses campos de força que são definidos e redefinidos nas negociações das margens, criando "credenciais de reconhecimento" ${ }^{366}$ para, assim, redefinir territórios.

Como foi visto em relação às dinâmicas dos programas habitacionais, o que definiu a postura do Estado em cada momento foi o potencial de votos devido às negociações de mercadorias políticas e os princípios disciplinares aplicados aos dóceis e rebeldes. Agora (no contexto do PMCMV), parece se tratar de um processo de redefinição do mercado formal que se estende à população de baixa renda para ampliação do controle sobre a terra e de monetarização da pobreza.

Nesse sentido, a regularização fundiária passa a ser usada também como ampliação de mercado, flexibilizando os parâmetros de legalidade da ocupação urbana, bem como flexibilizando os termos de declaração da propriedade no âmbito do registro de imóveis. Como visto, não se trata necessariamente da entrada desses terrenos em negociações pontuais do mercado formal, mas na capacidade de municípios e estados de estabelecerem controle sobre o registro da propriedade fundiária criando ambientes mais favoráveis e confiáveis aos negócios, principalmente os imobiliários. Nesse processo, a regularização fundiária como instrumento de resistência no campo legislativo no ato de reconhecimento da posse de ocupantes em detrimento do proprietário vai sendo abafado pela emergência desta outra forma de regularização fundiária neoliberal.

Por se tratar da transição da situação de irregularidade para uma situação de regularidade, significa que determinados tipos de ilegalismos passam a ser aceitos pelo Estado e podem integrar o sistema de legalidade. Essa opção, portanto, está relacionada à afirmação de Roy (2007) de que, em cada momento histórico, o Estado decide quais os informalismos que podem ser tolerados e quais devem ser extintos. Neste caso, a partir do estudo do Programa de Regularização Fundiária, é possível perceber que os informalismos tolerados passaram a ser legalizados.

${ }^{366}$ Das (2004, p.516). 
Essa abertura criada por mudanças na legislação federal, encabeçadas pela Secretaria de Habitação, mas que foram ajustadas no campo das operações imobiliárias, tornou-se possível a partir do momento em que se considerou a possibilidade de abertura de mercado por meio da regularização fundiária. Essa relação entre os ilegalismos e a economia formal foi discutida por Foucault (2015) que mostra que não é uma relação necessariamente negativa, pelo contrário, pode ser "compatível" e até "útil" ao desenvolvimento econômico. De fato, a utilidade da ocupação irregular e da autoconstrução na redução de salários já foi profundamente discutida, mas cabe aqui o destaque sobre como o ciclo da informalidade a partir dos deslocamentos promovidos pela Cohab-LD tem beneficiado o mercado imobiliário em Londrina. Nesse sentido, a distinção entre o "ilegalismo popular" e o ilegalismo do Estado também é importante.

Foucault (2015) define o "ilegalismo popular" como as práticas realizadas à margem dos regulamentos oficiais do sistema econômico (feudalismo) para que os envolvidos tivessem maiores ganhos, mas que possuem uma dimensão funcional ao capitalismo por beneficiar a burguesia. São ilegalismos que não atacavam a propriedade material, apenas direitos. Outra característica do "ilegalismo popular" era sua sistematicidade, por ter um modo de funcionamento ampliado sobre a sociedade inteira. Esses ilegalismos ainda eram combinados aos ilegalismos de comerciantes e de negócios.

No recorte deste estudo, quando a ocupação irregular entra em conflito com o mercado imobiliário, ou seja, deixa de ser funcional e passa a representar obstáculo para o mercado, o manejo ocorre para que o ilegalismo da ocupação assuma outra forma e deixe de ser obstáculo para tornar-se funcional. Foucault (2015, p.147) identifica, assim, quatro elementos que estão em jogo nesses contornos dos ilegalismos: a lei, a prática ilegal, os indivíduos e a riqueza. É desse modo, portanto, que se insere a ideia de que os ilegalismos não são combatidos, reprimidos ou censurados, mas são geridos conforme os interesses que estão em jogo no processo de produção e acumulação de riqueza.

Vai ser preciso manipular, vai ser preciso suscitar, vai ser preciso facilitar, vai ser preciso deixar fazer, vai ser preciso, em outras 
palavras, gerir e não mais regulamentar. (...) Vai ser preciso, portanto, enquadrar os fenómenos naturais de tal modo que eles não se desviem ou que uma intervenção desastrada, arbitrária, cega, não os faça desviar. Ou seja, vai ser preciso instituir mecanismos de segurança ${ }^{367}$.

Nesta mesma lógica proposta por Foucault, Telles ${ }^{368}$ aprofunda essa discussão com base nos estudos sobre a periferia de São Paulo, investigando os campos de força inseridos nos processos de gestão diferencial dos ilegalismos urbanos.

No quadro das mutações recentes (e em curso) desses mercados, as formas de intervenção governamental poderiam ser vistas como 'um conjunto de táticas que recriam a informalidade, transformando-a em governamentalidade' (Asayyad e Roy, 2009), táticas que combinam dispositivos políticos-jurídicos (conversão dos ambulantes em microempreendedores) e o uso da coerção para impor as novas regras, entre a repressão policial e a violência extralegal (chantagens, extorsão, expropriação de mercadorias). ${ }^{369}$

Aqui, é necessário acionar o conceito de legitimidade e monopólio da violência de Estado ${ }^{370}$. As normas são instituídas nas margens dos códigos jurídicos, desenhando as formas de informalidade toleradas ou reprimidas. Essa recriação da informalidade se torna possível devido à legitimidade do Estado. No extremo, podemos falar da conversão dos "invasores" em proprietários. Nesse sentido, argumento que a legitimidade do Estado é uma das principais ferramentas que possibilitam a gestão dos ilegalismos sem se questionar as contradições entre a produção e a repressão dos ilegalismos pelo próprio Estado.

\footnotetext{
${ }^{367}$ Foucault (2008, p.474, grifo meu).

368 Telles (2015); Telles (2006); e Telles e Hirata (2010). Para isso, é imprescindível o diálogo com os trabalhos de Telles que têm como questões centrais de seus estudos crime, tráfico, violência, e deslocamentos populacionais que transbordam as fronteiras dos estados-nação, no que se refere a esta gestão dos ilegalismos urbanos. Para Telles, compreender esses campos de força responsáveis pelos deslizamentos das fronteiras entre o legal e o ilegal no espaço da cidade - sobretudo por meio da pesquisa etnográfica - significa realmente aprofundar nos estudos urbanos.

${ }^{369}$ Telles (2015, p.521).

${ }^{370}$ Bourdieu (2014).
} 
É isso que se observa na gestão das ocupações irregulares realizada ao longo dos anos. Entre a tolerância - ocupações que datam da década de 50 - e a repressão - as violentas reintegrações de posse - estão os efeitos de poder das leis e dos códigos que são acionados conforme estão inscritas as relações de força em cada momento da política urbana. Nesse sentido, as leis operam para diferenciar os ilegalismos, para diferenciar as maneiras de contornar a lei ${ }^{371}$, já que a lei não define o que está dentro, mas o que está fora. E, por isso, "os ilegalismos não são imperfeições ou lacunas na aplicação das leis, eles compõem os jogos de poder e se distribuem conforme se diferenciam" 372 .

Referenciada em Agambem, Telles analisa o que ela chama de "dobras" ou "zonas cinzentas", ou seja, quando o legal e o ilegal se borram. Nessas margens, cada ilegalidade se torna uma moeda, uma mercadoria política em negociação, a partir da qual é possível compreender as capilaridades da ação do Estado. Em torno de cada uma dessas "zonas cinzentas" existe um campo de disputa que configura as margens do Estado em uma "zona de indiferenciação"373.

São nessas zonas em que se perde a referência da moradia digna, das condições mínimas de habitabilidade para se discutir os mecanismos burocráticos dos prérequisitos da propriedade privada. Se a ilegalidade é o padrão de habitação na gestão das urgências, trata-se de analisar como se usa a transitoriedade do ilegal - legal, como se seleciona por meio de uma "trama de atores" e de "apropriação dos espaços" para a gestão de bens e recursos.

Nesse sentido, sobre as remoções, podemos emprestar a afirmação de Telles (2006, p.79) que vai apontar a dimensão espacial da gestão dos ilegalismos:

(...) não se trata tão simplesmente de deslocamentos espaciais. A promoção dos espaços passa por um intrincado jogo de atores e campos multifacetados de conflitos e tensões. (...) No mais das vezes, arma-se um acirrado campo de disputas pelos usos dos 'espaços vazios', terras públicas ou sem proprietário definido, envolvendo

\footnotetext{
${ }^{371}$ Foucault (2010).

372 Telles e Hirata (2010, p.41).

373 Expressão usada por Agambem (2004).
} 
moradores, poderes públicos, e os 'invasores' e, por vezes, os chefes locais do narcotráfico que dominam o 'ponto'.

O caso da zona leste de Londrina nos mostra que as remoções compõem a estratégia de gestão dos ilegalismos na disputa em torno da valorização dos terrenos em uma área consolidada que passa por um processo de reestruturação imobiliária. A higienização, mascarada pelo discurso da preservação ambiental e legitimada pelos diagnósticos e documentos oficiais, promoveu deslocamentos espaciais viabilizando a produção e a reprodução do espaço urbano.

Deslocamentos espaciais e disputas pelo espaço; tramas sociais e mediações institucionais; temporalidades urbanas e os tempos políticos da cidade. (...) É aqui que talvez se esclareça a importância de perseguir as práticas e conceitos das mobilidades e trajetórias urbanas. São elas que nos dão as pistas desses pontos de condensação e de pólos de gravitação que definem a pulsação dessas dinâmicas urbanas. ${ }^{374}$

Diante da regra da moradia irregular em Londrina, este dispositivo foi criado para responder a uma urgência quando as disputas em torno da ocupação de áreas particulares passaram a interferir no funcionamento do mercado. Na medida em que este estado de urgência se transforma em regra, o dispositivo se transformou em uma política de Estado.

Neste momento de redefinição de aspectos da economia ligados ao imobiliário, quais são as demandas do circuito de capital que levaram a essa transitividade do legal - ilegal? Isso pode ser colocado em perspectiva diferenciando escalas: reestruturação imobiliária da zona leste de Londrina, APPs que não podem ser incorporadas ao mercado, e a titulação em massa de áreas ocupadas irregularmente. Portanto, há uma dimensão territorial que gravita por todas essas modalidades.

${ }^{374}$ Telles (2006, p.84). 


\section{Análise dos agentes na criação de políticas públicas}

Nesta pesquisa investigo o papel de duas instituições que compõem a ideia do público: a Cohab-LD, criada para operar recursos públicos (federais e municipais) para produção de habitação de interesse social; e o Cartório de Registro de Imóveis, criado para operar o controle do Estado sobre a terra.

Ainda, nesta análise sobre o papel do Estado na constituição da política habitacional de Londrina, o Estado está corporificado na Cohab-LD e no Cartório de Registro de Imóveis. Esses dois agentes evidenciam uma primeira característica do Estado que corresponde às intersecções entre o público e o privado.

A Cohab-LD é uma empresa de capital misto que, mesmo tendo a maior parte de suas ações de propriedade da Prefeitura do Município de Londrina, foi criada e é administrada como uma empresa do ramo imobiliário, que atende a um público-alvo categorizado na criação da demanda por habitação de interesse social. É possível afirmar que a maior ambiguidade está na atribuição de apontar soluções para um problema gerado pela lógica imobiliária (da propriedade privada) utilizando a própria lógica imobiliária.

Apesar da criação da Cohab-LD ter a finalidade de atuação no mercado imobiliário para atender a faixas de renda mais baixa e garantir retorno financeiro ao BNH, vimos que o viés político direcionou a atuação da Cohab-LD por anos. Mesmo que a serviço de interesses particulares, como nos casos de desocupação de áreas valorizadas, a gestão apresentava muito mais características populistas do que de caráter empresarial. Porém, nos últimos anos, foi possível observar uma transformação no modo de gestão da Companhia. Durante a administração que se dizia empresarial (Gestão Kireff), o programa de regularização fundiária foi estabelecido a partir da definição de metas, visando o menor custo do programa, notadamente com princípios de uma racionalidade empresarial. Esta lógica empresarial como paradigma da administração de órgãos públicos é uma das características do governo neoliberal, em que a lógica empresarial permeia todas as esferas de governo, da concepção de políticas públicas até a subjetividade individual. O apontamento de Laval e Dardot (2013) sobre 
o papel dos Estados faz referência à construção política dos mercados financeiros, fortalecidos com uma série de reformas nas legislações. Os autores mostram que as finanças se disseminam por meio da globalização e, assim, os donos desse capital passam a ter influência nas mais diversas localidades. O argumento é que essa combinação de fatores dá início a uma associação entre Estado, gestão empresarial e capital financeiro que gera uma nova norma de conduta que tem a empresa como modelo de gestão e parâmetro de eficiência. Essa estrutura econômica se sobrepõe aos governos nacionais, e consequentemente, aos estaduais e municipais. Apesar do papel ativo do Estado na prática, a racionalidade neoliberal institui ideologias que fortalecem a visão de que a empresa representa o ideal de avanço e desenvolvimento e deve, portanto, servir de modelo para a atuação do Estado. O gerenciamento que caracteriza "as regras de funcionamento do mercado competitivo" 375 é adotado na administração do setor público. O Estado torna-se uma empresa a serviço de outras empresas e será avaliado pela coerência em relação às boas práticas econômicas de governança ${ }^{376}$. Os empréstimos vinculados ao BID associados às diretrizes pré-estabelecidas pelo Banco e a centralidade dos Cartórios de Registro de Imóveis no procedimento da regularização fundiária são evidências desses processos.

Por sua vez, o Cartório de Registro de Imóveis tem um papel relevante em todo o procedimento do programa de regularização fundiária, sendo o responsável pela concessão dos documentos que, neste modelo, efetivam a realização do programa. Entretanto, o que se constata é que os custos e a burocracia destes procedimentos são fatores que inviabilizaram a regularização fundiária até agora. Os cartórios, responsáveis por prestar o serviço público do registro, também são geridos sob a lógica privada, e são os preços elevados dos procedimentos de registro que tornam essa atividade altamente rentável. Por isso que a disputa pela gratuidade nos procedimentos relacionados à regularização fundiária de interesse social evidencia a ambiguidade na prestação de serviços públicos sob a lógica privada.

375 Laval e Dardot (2013, p. 277).

376 Laval e Dardot (2013). 
Os agentes em estudo, Cohab-LD e Cartórios de Registro de Imóveis, também carregam uma outra ambiguidade no campo da política habitacional. Ambos foram criados para a sustentação da propriedade privada, sobretudo nos casos de conflito em torno da posse de imóveis. Desse modo, observa-se que há, claramente, uma tendência do Estado em sustentar o modelo da propriedade privada na concepção dos programas habitacionais.

Para programas relacionados à produção de lotes urbanizados ou conjuntos habitacionais de interesse social isso é mais evidente, ainda que essa influência não se esgote na entrega da propriedade privada individual por meio de financiamentos habitacionais, como visto sobre as motivações locacionais dos empreendimentos. Porém, no que se refere aos programas de regularização fundiária, esta questão fica mais complexa já que a origem do instrumento da regularização fundiária está justamente ligada ao conflito fundiário em torno da posse de imóveis para habitação. Neste caso, portanto, o compromisso do Estado com a propriedade privada compromete a função deste instrumento e é isso que está posto em questão nesta análise.

Se a lógica da propriedade privada ${ }^{377}$ norteia a ação destes agentes responsáveis pela concepção e execução dos programas habitacionais, inclusive de regularização fundiária, a própria formulação das políticas (ou dos programas) precisa ser compreendida a partir dessa constatação.

Segundo Bourdieu (2014, p. 488), “a edificação do Welfare State supõe uma verdadeira revolução simbólica, que tem como centro a extensão da responsabilidade pública no lugar da responsabilidade privada", portanto estamos caminhando na

\footnotetext{
377 Considerando a terra em sua forma mercadoria, a especulação imobiliária é naturalizada como fator inerente ao processo de valorização do imóvel e, consequentemente, aumento da renda. Do mesmo modo que a Cohab-LD vê nesse processo uma oportunidade de garantir uma rentabilidade futura sobre os terrenos de sua propriedade, o registro dos imóveis é a garantia do proprietário em casos de ocupação irregular. Nesse sentido, sob essa lógica proprietária, os dois principais agentes envolvidos na concepção e execução do programa de regularização fundiária em Londrina de fato não têm interesse no reconhecimento da posse de ocupantes de terrenos que permanecem vazios no processo de especulação e consequente valorização imobiliária.
} 
contramão, em direção a políticas neoliberais cada vez mais permeadas pela lógica privada.

E se é fato que o que está no centro da questão habitacional é a lógica excludente da propriedade privada do solo urbano, o que está no centro, portanto, da formulação de políticas habitacionais é o apaziguamento do conflito fundiário por meio da formulação de um consenso em torno da propriedade privada e sua distribuição entre os grupos sociais. Assim, o monopólio da propriedade é garantido pelo Estado.

A criação das políticas públicas e programas pressupõe a definição de "públicosalvo" a partir de um enquadramento definido com base em levantamentos estatísticos que possibilitam a leitura da população pelo Estado e por ela mesma. Segundo Bourdieu (2014, p. 38), "uma das funções mais gerais do Estado é a produção e a canonização das classificações sociais", então, "não por acaso há um vínculo entre o estado e as estatísticas" que viabilizam o estabelecimento destas classificações. Assim, para viabilizar as políticas, os indivíduos são constantemente "quantificados, codificados pelo Estado, [têm] uma identidade do Estado" ${ }^{378}$. É dessa maneira que opera a homogeneização das políticas, a criação do "público-alvo", pelo enquadramento.

Esta é a forma do Estado de construir as subjetividades, de tornar a população legível para ela mesma, mas é, sobretudo, uma forma de reduzir os conflitos cotidianos dos grupos excluídos, de homogeneizar as demandas em torno de uma única solução: ser contemplado com uma casa em um conjunto habitacional, ou receber um título de propriedade.

A criação de um público-alvo, a "faixa zero a três salários mínimos", aqueles que nunca foram atendidos pela política habitacional, etc., "enquadrou" $10 \%$ da população de Londrina na "fila da Cohab-LD", o cálculo do déficit baseado em critérios genéricos, levantamento pouco sistematizados, estatísticas generalistas e, ao mesmo tempo, fragmentárias, tudo isso oculta o conflito da formulação da "questão habitacional" construindo, por meio da instituição de verdades, um consenso em torno dos interesses do Estado.

\footnotetext{
${ }^{378}$ Bourdieu (2014, p.38).
} 
Trata-se da construção de uma política “ilusória, mas coletivamente validada pelo consenso" 379 que, para Bourdieu, aquela realidade ilusória pode existir já que os indivíduos são levados a crer por um conjunto de fenômenos legitimados por documentos emitidos pelo Estado, como diplomas, títulos profissionais, calendário, etc. e, também podemos acrescentar aqui, os cadastros sociais e os registros de imóveis.

Para ilustrar as relações de força econômica e simbólicas que existem na interação entre sujeito e Estado, Bourdieu (2014), tratando do mercado da casa própria, mostra que um potencial cliente passa por uma avaliação e uma classificação baseada inteiramente na sua capacidade de obtenção de crédito em banco, enquanto o vendedor, autorizado pelo Estado, opera como aquele que dirá, analisando sua situação, se você tem ou não direito de comprar uma casa. No caso do atendimento da Cohab-LD não é diferente. É a autorização, a concessão do direito de tornar-se público-alvo de uma determinada política, de ser o "beneficiário".

Isso pode ser claro, como no caso da lei que criminaliza as ocupações e exclui os ocupantes do desenho da política, ou pode ser ilegível, com critérios indefinidos que possibilitam a escolha do público-alvo que interessa em um determinado momento. É nesse sentido que passo a entender o que Bourdieu chama de "produção da demanda".

Desse modo, para cada concepção da política pública, é elaborada uma "nova definição legítima de um problema público, propõem uma nova maneira de fornecer aos cidadãos meios de satisfazer o que lhes é dado como um direito, isto é, a necessidade de moradia" 380 .

A elaboração depende de um conjunto de fatores externos e internos à estrutura do Estado. No momento da elaboração dos programas habitacionais criados pela Lei Federal no 11.977/2009, vê-se a influência do mercado financeiro representado pelas construtoras de capital aberto ${ }^{381}$ e as agências multilaterais confirmando o papel central do setor imobiliário neste momento da economia financeirizada global.

\footnotetext{
379 Bourdieu (2014, p.38).

380 Bourdieu (2014, p.59).

${ }^{381}$ Shimbo (2010).
} 
É essa teatralização do Estado, com suas burocracias, leis e documentos, que confere legitimidade às práticas, que possibilita ao Estado sustentar as ambiguidades das práticas, produzir ilegalismos ao mesmo tempo que os reprime, negociar mercadorias políticas sem ser questionado ou confrontado. Por isso, a importância de "salvar a regra mesmo no caso da sua transgressão" ${ }^{382}$, para sustentar os parâmetros de normalidade que definem os campos dos possíveis.

Há uma lógica específica do Estado e essas pressões, essas regularidades, esses interesses, essa lógica do funcionamento do campo burocrático podem estar no princípio da dependência ou da independência em relação a interesses externos ou, melhor ainda, de correspondências não desejadas em relação a interesses externos. (...) Mas ocorre que se trata de coincidência (eu exagero um pouco); no máximo, esses agentes ao se servirem, serviram sem saber e sem querer, mais os interesses deste grupo ou daquele; podemos até mesmo dizer um pouquinho mais: "no final das contas", "pensando bem", "globalmente", todos esses jogos do Estado servem mais uns que outros, servem mais os dominantes do que os dominados. ${ }^{383}$

Desse modo,

Leis e códigos formais têm efeitos de poder que condicionam o modo como esses mercados e atividades se estruturam. Circunscrevem jogos de poder e relações de força que operam em um campo de disputa no qual se combinam e alternam negociação, formas de controle, tolerância e repressão. ${ }^{384}$

Por isso, nesta interpretação das leis que regulam tal transitividade entre o legal e o ilegal, a análise deste campo de disputa que envolve o conflito fundiário e agentes do Estado profundamente ligados à sustentação da propriedade privada permitiu compreender como a gestão dos corpos incidiu sobre o território por meio desses dispositivos e mecanismos de poder. A análise dos agentes - Cohab-LD e Cartórios permitiu compreender não só o que passou a ser permitido no processo de flexibilização

\footnotetext{
382 Bourdieu (2014, p.84).

383 Bourdieu (2014, p.163).

${ }^{384}$ Telles (2015, p.511).
} 
da legislação, mas também interpretar as tolerâncias e as proibições, evidenciando que a gestão dos ilegalismos promovida por meio da implementação de programas habitacionais possibilita ao Estado a gestão do território sob a lógica da propriedade privada e dos contornos do conflito fundiário ${ }^{385}$.

Desse modo, a lei vai desenhando e classificando os ilegalismos e, por isso, o poder legislativo é central nesses contornos e disputas. As revisões e a flexibilização característica do governo neoliberal ${ }^{386}$, são evidências de que a afirmação de Foucault (2015, p.137) segue atual: “o poder legislativo estava assim profundamente ligado, na burguesia, à prática do ilegalismo". Essa afirmação possibilita o diálogo com a interpretação de Pachukanis (1988) sobre o direito e a sustentação do modelo econômico.

Como observou Pachukanis, não é a norma jurídica que cria sujeitos de direitos, é o fato concreto das relações sociais existentes no nível da produção e da relação entre as pessoas, um vínculo econômico entre as pessoas. A vida concreta que fez com que as pessoas se submetessem umas às outras. Trata-se da transformação da exploração em relação formal em que o trabalhador vende a sua força de trabalho e o empresário compra essa força de trabalho mediante uma relação de contrato. Portanto, nessa perspectiva, são dois proprietários comercializando mercadorias. É assim que o "poder político de classe pode revestir-se da forma de um poder público" ${ }^{387}$, e é por isso que o poder do direito é considerado um poder imparcial. A teoria jurídica do Estado coloca o Estado "como um poder autônomo destacado da sociedade" 388 e a ideia de poder público implica a interpretação de um poder que está acima de todos. Essa "autoridade geral”389 que transforma o Estado jurídico em miragem é conveniente à burguesia justamente pelo fato de que oculta das massas as relações de dominação que partem

\footnotetext{
385 Sobre isso, Foucault nos alerta que "É um preconceito dos intelectuais acreditar que existem primeiramente interditos e depois transgressões (...); na verdade, se tivermos de entender e analisar um interdito em relação àquilo que ele proíbe, também será preciso analisá-lo em função daqueles que proíbem e daqueles sobre os quais incide a proibição" (Foucault, 2015, p.134).

${ }^{386}$ Vainer (2011).

387 Pachukanis (1988, p.96).

388 Pachukanis (1988, p.99).

389 Pachukanis (1988, p.100).
} 
da burguesia, à medida em que o Estado representa hipoteticamente a vontade de todos $^{390}$. A sociedade aparece, portanto, como um mercado e, assim, o Estado parece representativo da vontade geral, uma entidade impessoal.

Agora, se falamos em ocupações irregulares, e não em uma relação de troca que envolve a mercadoria (especial) terra, toda a regulação que decorre do reconhecimento da posse sem que haja uma troca no mercado formal trata-se de uma medida de exceção. Porém, segundo o autor, as medidas adotadas no direito quando os contratos não são cumpridos (ou quando não há contrato, como no caso de ocupações irregulares), são vistas como autoritárias. É assim que a tradição clássica do direito que norteia a atuação dos profissionais do registro de imóveis interpreta o instrumento da regularização fundiária. Como coloca Pachukanis (1988, p.103), dado o agravamento da luta de classes no seio da sociedade profundamente injusta, a burguesia se viu obrigada a "desmascarar completamente o Estado de direito e a desvendar a essência do poder de Estado como a violência organizada de uma classe da sociedade sobre as outras".

Nessa lógica, não é possível considerar que as propostas de reformas no sistema legislativo representariam de fato resistências ao modelo econômico. Trata-se das resistências nos campos dos possíveis, reformas que podem minimizar os efeitos de poder, ou contorná-los em direção a modelos menos opressores, menos injustos, mas nunca possibilitará a superação deste modelo.

${ }^{390}$ Pachukanis (1988). 


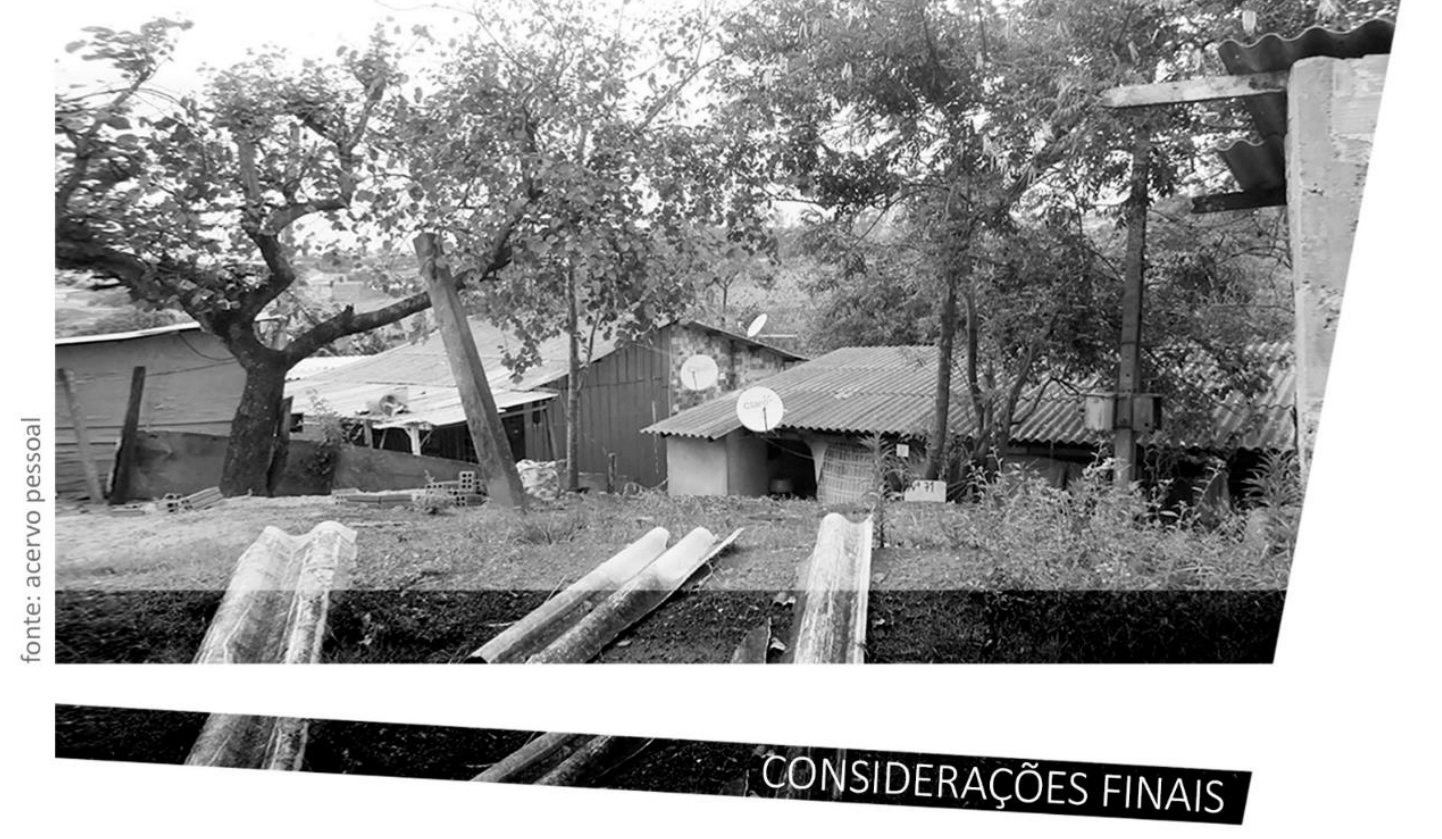




\section{Considerações Finais}

Esta pesquisa trouxe questões relativas à política habitacional e sua relação com as dimensões de poder do Estado, dispositivos e mecanismos disciplinadores dos sujeitos e da população e a constituição de territórios. Os programas habitacionais analisados permitiram compreender a mecânica da gestão dos ilegalismos promovida pela Cohab-LD, elucidam as diferentes dimensões da violência que penetra no cotidiano das famílias, agravando as condições de vulnerabilidade, como processo de sustentação da precariedade como modo de vida.

A partir do estudo de caráter genealógico, foi possível identificar como se institui a remoção de favelas como uma verdade e, portanto, uma prática necessária. A combinação entre esses discursos que constroem verdades, as leis que conferem legitimidade e a reprodução das práticas, seguindo a lógica de Foucault, configura um dispositivo de poder. Ainda, pesquisar os programas de perto e de dentro permitiu apreender a mecânica desse dispositivo, compreender a operacionalização do controle sobre o conflito fundiário que emerge nesse contexto altamente desigual, especulativo e rentista. Os programas habitacionais em questão vão sendo moldados a partir da perspectiva diferencial com que o Estado define quais os ilegalismos que serão tolerados e quais devem desaparecer. Assim, tal operacionalização tem como objetivo gerir a vida, para gerir o território. Entretanto, fica claro, que não se trata de uma simples e autoritária imposição. O "deixar ocupar" e "fazer se deslocar" faz parte do processo. Essas são formas de governo das margens e pelas margens que pude compreender a partir desta pesquisa empírica realizada em Londrina. O principal resultado desse processo é a gestão do conflito, delimitando um campo de possibilidades para as negociações.

Já são inúmeros os apontamentos que associam a renovação e reestruturação de áreas urbanas e os deslocamentos populacionais, seja pela via da remoção involuntária, com ou sem conflito, seja pela via da gentrificação. Os programas concebidos e executados no âmbito da política habitacional legitimam esses 
deslocamentos a partir do pressuposto da vulnerabilidade e do risco. Ao mesmo tempo, e em oposição, as ocupações irregulares são manifestações do conflito fundiário inerentes à nossa sociedade. Enfrentam a hegemonia da propriedade privada e contestam a lei que exclui parte da população do acesso à moradia. As ocupações cobram do Estado, de forma declarada ou não, o direito de desfrutar do direito à moradia, um direito constitucional.

Por meio da pesquisa é possível constatar que a gestão dos ilegalismos é, de fato, diferencial, tendo em vista que somente a informalidade dos pobres é criminalizada. Observa-se que o uso da força não é uma constante das práticas, mas isso não quer dizer que não há violência, e as estratégias de coação elucidam essas diferentes dimensões da violência presentes nessas práticas. Se as remoções deixam de ser questionadas, se não são estudadas outras possibilidades de atendimento, significa que a legitimidade das práticas pautada na construção de verdades cria um "campo cego" acerca das soluções para os problemas habitacionais.

Enquanto a situação de desigualdade extrema e miséria, de direitos obliterados ${ }^{391}$, é mantida e sustenta o modelo de acumulação das cidades, o Estado mantém os conflitos em uma zona controlável de insurgências possíveis, contornando as reivindicações e manifestações dos conflitos com soluções projetadas para falsos problemas. Os efeitos de poder se capilarizam sobre os sujeitos, as verdades construídas são disseminadas e absorvidas e os dispositivos de gestão da vida criam subjetividades de modo que as soluções estatais são incorporadas nas reivindicações. Essas práticas são sustentadas pelo controle do saber e da operacionalização dos dispositivos disciplinares que criam corpos dóceis e delimitam esses campos dos possíveis. A gestão dos ilegalismos corresponde ao "como" deste processo.

Nesse sentido, em Londrina, algumas ocupações reivindicaram (e lutaram) pela permanência, em contraposição às remoções para os conjuntos do PMCMV. É fato que a nova regulamentação do instrumento da regularização fundiária e a elaboração do

${ }^{391}$ Cordeiro (2015). 
programa municipal correspondente abriu novas possibilidades para negociações e para a permanência dos moradores no local da ocupação, principalmente em áreas públicas. Essa fagulha de avanço foi vista no caso do Jd. San Rafael, agora considerado apto à regularização. Em áreas particulares, o Estado segue atuando em benefício do proprietário, independente do sistema de legalidade. A ausência de recursos para a urbanização é evidentemente uma limitante fundamental para se discutir a regularização fundiária plena no âmbito municipal.

Isso ocorre porque a iniciativa da promoção da regularização fundiária partiu da Cohab-LD, e foi debatida e disseminada sob a perspectiva do mercado. Fica, dessa forma, desvinculada do debate efetivo sobre a melhoria das condições de vida e do enfrentamento do conflito fundiário.

Ou seja, sua importância enquanto instrumento de luta política se efetiva no âmbito legislativo, e isso não é pouco. A importância política do Movimento pela Reforma Urbana é evidente e influenciou todo o conjunto de leis que diz respeito à política urbana e que aponta limites (ainda que enquanto medidas de exceção) à lógica de mercado que, historicamente, condicionou a legislação urbanística (como as leis de uso e ocupação do solo urbano e de parcelamento do solo para fins urbanos). Exatamente por esse motivo, é necessário questionar a apropriação do instrumento de regularização fundiária pelo mercado (e pelo Estado, sob a lógica da boa governança).

A pesquisa também mostra que o mercado viu a necessidade de promover a regularização fundiária como parte dos ajustes necessários para a criação de ambientes favoráveis e confiáveis aos negócios, sobretudo relacionados a operações imobiliárias e financeiras. Por isso, ela passou a ser disseminada como estratégia de ampliação de mercado e de controle sobre a terra. A análise dos Cartórios de Registro de Imóveis enquanto agentes desses programas permite fazer essa afirmação. Agora, o texto da Lei Federal $n=13.465 / 2017$ evidencia todas essas questões, principalmente devido ao foco exclusivo na titulação e da promoção da regularização fundiária em massa para situações em que não se aplica a premissa do interesse social. 
Tendo em vista a ascensão do mercado imobiliário nesse novo momento do capitalismo, ao que Lefebvre (2002) chama de urbanização, observa-se que os preços para acessar o uso da terra ascenderam da mesma forma, se distanciando cada vez mais da capacidade de compra dos trabalhadores assalariados. No entanto, com a expansão do sistema de crédito e da importância que ele assume para a acumulação de capital, os incentivos para a aquisição da propriedade privada da terra também aparecem intensificados, bem como o uso dos imóveis como garantia e fixação de capital em operações financeiras. Essa associação entre a propriedade privada da terra e a acumulação de capital (fictício) marca a transição da propriedade privada da terra como um entrave para se tornar uma alavanca à acumulação.

Portanto, um programa que foi reivindicado no âmbito da política habitacional e enfrentou barreiras para a regulação por contestar o modelo de ocupação do solo urbano baseado na propriedade privada monopolista e excludente, torna-se necessário no contexto da ampliação do mercado de terras e a consequente necessidade de ampliar o controle sobre as operações imobiliárias.

Essa assimilação dos instrumentos que historicamente foram objeto de reivindicações populares indica não somente a iniciativa de monetarização da pobreza, principalmente a destituição do aspecto político das reivindicações que, contraditoriamente à ampliação do mercado visada pela disseminação do instrumento nessa conjuntura, buscavam a contestação da lógica do mercado.

Apesar das inúmeras críticas a respeito da teoria de De Soto, ela segue sendo disseminada como possibilidade de ampliação de mercado nos países emergentes, juntamente com os demais princípios neoliberais disseminados pelas agências multilaterais. Além dos financiamentos de programas habitacionais que sustentam a lógica do endividamento de estados e municípios e difundem a proposta de "inclusão" dos pobres pela via do mercado, impõem uma agenda institucional pautada na governança neoliberal. 
Laval e Dardot $^{392}$ propõem a teoria de que se instaura uma nova racionalidade neoliberal por meio de dispositivos de poder que alcançam inclusive o Estado, transformando significativamente as políticas públicas. Diante dos programas recentes lançados pelo Governo Federal brasileiro, são evidentes os objetivos balizados por tal racionalidade. No entanto, também se instaura a indagação de como essa nova razão de governar tem incidido no âmbito municipal tendo em vista que, para essa nova fase neoliberal, teorias apontam o espaço urbano como um dos principais ativos para acumulação de capital por meio das obras de urbanização.

Cabe enfatizar como a lógica empresarial está incorporada à palavra "gestão". Laval e Dardot ${ }^{393}$ discutem como a lógica empresarial tem se tornado referência para todas as instâncias da vida, inclusive para a administração pública. Apresenta-se em oposição à "burocracia" e "ineficiência" do Estado, fazendo com que a cidade seja governada (ou gerenciada) como uma empresa, anulando o caráter político do poder público. Essa racionalidade é instaurada mediante uma subordinação completa a um modelo de prática política e de relações sociais, que são reorientadas em uma nova direção e articuladas com a mundialização e financeirização do capital embasadas por uma nova lógica normativa ${ }^{394}$.

O novo modelo impõe ao Estado novos compromissos políticos, e difere do liberalismo tradicional na medida em que insere o Estado como ator fundamental na criação das condições mais favoráveis para a reprodução e valorização de capital e na disseminação dessa racionalidade. De acordo com Laval e Dardot, são definidas novas bases, novos métodos e novos objetivos para a atuação do Estado que preconizam a economia livre e o Estado forte. Os autores deixam evidente com as colocações que não se trata apenas de um retorno do mercado após a crise, mas que há uma reestruturação nos processos de reprodução que reerguem e fortalecem o sistema.

\footnotetext{
392 Laval e Dardot (2013).

393 Laval e Dardot (2013).

${ }^{394}$ Laval e Dardot (2013).
} 
A inserção do Estado, que até então deveria se isolar para não "atrapalhar" a atuação do mercado, é colocada quase que unicamente para atender aos interesses privados, criando as melhores condições fiscais e de liberdade quanto aos marcos regulatórios. Consolida-se dessa maneira uma coalizão de forças que possibilita a disseminação dos princípios neoliberais de origem privada à esfera pública. Assim, os governos responsáveis pela implementação de regras jurídicas, monetárias e comportamentais, além das regras de competição entre empresas, assumem agora a função de criar situações de mercado e adequar os indivíduos à lógica vigente por meio de técnicas disciplinares ${ }^{395}$

Nesse sentido, outro apontamento dos autores sobre o papel dos Estados faz referência à construção política dos mercados financeiros, fortalecidos com uma série de reformas nas legislações. Os autores mostram que as finanças se disseminam por meio da globalização e, assim, os donos desse capital passam a ter influência nas mais diversas localidades, gerando diferentes formas de homogeneização em diversos campo, como na economia, na produção do espaço urbano, nas relações de sociabilidade, entre outros.

Sendo assim, os resultados provocam a reflexão acerca do ensino do planejamento urbano e do projeto urbano e sobre os temas e métodos de pesquisa que tem encaminhado a busca de soluções para a cidade a partir de um "campo cego" criado sobre o Estado. A perspectiva institucional nos leva a uma luta no campo legislativo (entre audiências, conferências e planos de desenvolvimento), enquanto o cotidiano está permeado pelas práticas e pela violência do Estado que atua de forma capilarizada, construindo subjetividades por meio das estratégias de dominação.

Analisando o discurso disseminado, a reflexão sobre o papel dos planos de desenvolvimentos e seus diagnósticos ${ }^{396}$ é urgente e necessária. São eles que legitimam as distorções observadas na criação de instrumentos e aplicação da legislação. A lei é

\footnotetext{
395 Laval e Dardot (2013).

${ }^{396}$ Planos e diagnósticos que visam analisar condições de precariedade da vida, mas que transformam as vidas em números, percentuais, pontos e linhas em mapas, que criam "públicos-alvo", constroem demandas e subjetividades.
} 
um instrumento de poder e, por isso, é também um campo em disputa. Por isso, hoje, a flexibilização é a norma para promover o ajuste necessário ao reestabelecimento do mercado, sobretudo o imobiliário. A gestão diferencial está baseada na "autonomia relativa do Estado" para decidir qual delas permanecerá na informalidade e para qual se aplicará o "estado de exceção" 397.

Desse modo, inferir sobre esses aspectos só foi possível devido à pesquisa empírica desenvolvida em Londrina e a aproximação da dimensão cotidiana das práticas do Estado. Esta pesquisa também foi um exercício de observação de todas essas verdades construídas no meu saber. Vivemos em "cidades faveladas" ${ }^{398}$, que podem ser regularizadas devido à disseminação da tese de De Soto, criando cidades legalizadas e precárias. Nesse sentido, avisto um caminho nas palavras de Roy (2017) quanto à emergência do urbanismo subalterno e às novas possibilidades para a pesquisa sobre o urbano que se abre nesse campo.

${ }^{397} \operatorname{Roy}(2007)$.

${ }^{398}$ Roy (2017). 


\section{Referências Bibliográficas}

AGAMBEM, G. Estado de exceção. Trad. Iraci D. Poleti. 2ed. São Paulo:Boitempo, 2004.

ALFONSIN. M. B. O significado do Estatuto da Cidade para os processos de regularização fundiária no Brasil. In: ROLNIK, R. [et al]. Regularização fundiária sustentável - conceitos $e$ diretrizes. Brasília: Ministério das Cidades, 2007. Disponível em: http://www.urbanismo.mppr.mp.br/arquivos/File/Livro_Regularizacao_Fundiaria_Plen a_Referencias_Conceituais.pdf. Acesso em: 24/10/2019

ALMEIDA, G. M. J. A.; SANTOS, R. B. O perfil da demanda do Programa Papel Passado: resultados de pesquisa de nacional nos 200 municípios participantes do Programa. In: Caminhos para as políticas de regularização fundiária no contexto da crise brasileira: resultados, avanços e obstáculos ('antigos' e 'novos'). Alex Ferreira Magalhães (Coord.). (Sessão Livre) Anais do XVII Enanpur. Encontro Nacional da Associação Nacional de PósGraduação e Pesquisa em Planejamento Urbano e Regional. São Paulo: FAUUSP, 2017.

MORETTI, J. A. E GUIMARÃES, I. M. S. S. A Política Nacional de regularização fundiária: capacidades institucionais dos municípios na implementação do programa federal papel passado e suas implicações na gestão do território. Anais do XVII Enanpur. Encontro Nacional da Associação Nacional de Pós-Graduação e Pesquisa em Planejamento Urbano e Regional. São Paulo: FAUUSP, 2017.

ALVES, J. História da assistência social aos pobres em Londrina: 1940 - 1980. Tese de doutorado. Assis: UNESP, 2002.

AMORIM, W. A produção imobiliária e a reestruturação das cidades médias: Londrina e Maringá/PR. Tese de doutorado. Presidente Prudente: UNESP, 2015

. A produção social do espaço urbano em Londrina - PR: A valorização imobiliária e a reestruturação urbana. (Dissertação de Mestrado) Programa de pósgraduação em Geografia da Universidade Estadual Paulista Julio de Mesquita Filho FCT/UNESP. Presidente Prudente, 2011.

ARANTES, O. Berlim e Barcelona: duas imagens estratégicas. São Paulo: Annablume, 2012.

ARANTES, P. O ajuste urbano: As políticas do Banco Mundial e do BID para as cidades latino-americanas. (Dissertação de mestrado) Universidade de São Paulo, São Paulo, 2004.

AZEVEDO, S. Vinte e dois anos da política de habitação popular (1964-86): criação, trajetória e extinção do BNH. Revista de administração Pública, Rio de Janeiro. 107-119, out/dez 1988. 
AZUELA, A. El panorama de ideias sobre el derecho de propriedade. (1998). In: In: SMOLKA, Martin O. e MULLAHY, Laura (editores). Perspectivas urbanas, temas críticos em políticas de suelo em América Latina. Cambridge: Lincoln Institute of Land Police, 2007, pp.79-81.

BAIERLE, S. Da crise do participacionismo comunitário cidadão à precificação da coesão social In: Varner, C. (coord.) Sessão Livre "Da reforma urbana ao Minha Casa Minha Vida: balanço de 30 anos de lutas e políticas urbanas. Anais do XVII ENANPUR, v. 17 n. 1 São Paulo, 2017.

BARTLO, R. H. Padrões da segregação residencial em Londrina - PR :1930 - 2010.2015. (Dissertação de Mestrado). Universidade Estadual de Londrina, Londrina, 2015.

BENATTI, A. P. O Centro e as margens: Boemia e prostituição na "capital mundial do café" (Londrina: 1930-1970). (Dissertação de Mestrado) Universidade Federal do Paraná, Curitiba, 1996.

BOLAFFI, G. (1975). Habitação e Urbanismo. O problema e o falso problema. In: MARICATO, E. (org). A produção capitalista da casa (e da cidade) no Brasil industrial. São Paulo: Editora Alfa-Omega, 1982.

BONDUKI, N. (Coord.). Os pioneiros da habitação social - v. 1: cem anos de construção de política pública no Brasil. São Paulo: Ed. UNESP; Ed. SESC, 2014. 387 p.

no 127, 1994. . Origens da habitação popular no Brasil. Análise Social, Lisboa, v.24, Política habitacional e inclusão social no Brasil: revisão histórica e novas perspectivas no governo Lula. Revista Eletrônica de Arquitetura e Urbanismo, São Paulo, n.1, p.70-104, 2008.

BORJA, J.; FORN, M. Políticas da Europa e dos Estados para as cidades. In Espaço e Debates, ano XVI, n. 39, 1996

BOURDIEU, P. Sobre o Estado: Cursos no Collège de France (1989-92). Trad. Rosa Freire d'Aguiar. 1a ed. São Paulo: Companhia das Letras, 2014.

BRASIL. Estatuto da cidade: guia para implentação pelos municípios e cidadãos: Lei n. 10.257, de 10 de julho de 2001, que estabelece diretrizes gerais da política urbana. -2 . ed. - Brasília, Câmara dos Deputados, Coordenação de Publicações, 2002.

CALDEIRA, Tatiane Monteiro. Cidade Ocupada: conflito fundiário de moradia urbana e a atuação dos movimentos sociais na ocupação Flores do Campo - Londrina-PR. 2019. 157 f. (Dissertação de Mestrado) Universidade Estadual de Londrina, Londrina, 2019.

CALDERÓN COCKBURN, J. (1999). Algunas consideraciones sobre los mercados ilegales e informales de suelo urbano en América Latina. Lincoln Institute of Land Policy. 
- Títulos de propiedad, mercados y políticas urbanas. Revista de la Organización Latinoamericana y del Caribe de Centros Históricos. núm. 3, abril, 2009, pp. 47-62

CARDOSO, A. L.; ARAGÃO, T. A. Do fim do BNH ao Programa Minha Casa Minha Vida: 25 anos da política habitacional no Brasil. In: CARDOSO, A. L. O Programa Minha Casa Minha Vida e Seus Efeitos Territoriais. Rio de Janeiro: Letra Capital, 2013. p. 17-66.

CARVALHO, H. A. O. A Caixa Econômica Federal como agente da política habitacional: um estudo a partir do PAC e PMCMV em Carapicuíba. 2015. (Dissertação de Mestrado) Instituto de Arquitetura e Urbanismo, Universidade de São Paulo, São Carlos, 2015.

CORDEIRO, S. M. A busca por moradia: a trajetória de famílias moradoras em áreas irregulares na poligonal Turquino-Maracanã. (Dissertação de Mestrado). Universidade Estadual de Londrina. Londrina, 2006.

- Obliterações do direito à moradia na política habitacional de interesse social do município de Londrina-PR. (Tese de doutorado). Universidade Estadual de Londrina, Londrina, 2015.

CORDOVIL, F. C. de S. (2013). A formação urbanística do engenheiro Jorge de Macedo Vieira e o plano inicial de Maringá, PR. URBANA: Revista Eletrônica Do Centro Interdisciplinar De Estudos Sobre a Cidade, 5(2), 178-200.

COSTA, D. O conceito de direito real. Revista de Informação Legislativa. Brasília a. $36 \mathrm{n}$. 144 out./dez. 1999.

DANTAS, B. Tipicidade dos Direitos Reais. Revista Jurídica da Presidência Brasília v. 20 n. 121 Jun./Set. 2018 p. 439-463

DAS, V.; POOLE, D. (Ed.). Anthropology in the margins of the state. Santa Fe: School of American Research Press, 2004

.El estado y sus márgenes. Etnografías comparadas. Cuadernos de Antropología Social № 27, pp. 19-52, 2008 (C) FFyL - UBA - ISSN: 0327-3776

DAS, V. The Signature of the State: The Paradox of Illeibility. In: DAS, V.; POOLE, D. (Ed.). Anthropology in the margins of the state. Santa Fe: School of American Research Press, 2004

DUARTE, L.; BARROS, J. Entrevista Francisco de Oliveira. In: BARROS, J.; SILVA, E. B.; DUARTE, L. Cidades e conflito: o urbano na produção do Brasil contemporâneo. Rio de Janeiro: FASE, 2013.

ECOPOLIS. Etapa IV. Planos de urbanização de ZEIS. Zonas Especiais de Interesse Social. Londrina, 2009. 
FACCHINI, N. M. O direito à moradia $x$ o direito de propriedade. Conteúdo Jurídico, Brasília-DF: out. 2014.2 Disponível em: http://www.conteudojuridico.com.br/?artigos\&ver=2.50122\&seo=1. Acesso em: 16 jul. 2019.

FERNANDES, E. Cidade legal x ilegal (2001). In: VALENÇA, Márcio Moraes (org.). Cidade (i) legal. Rio de Janeiro: Mauad, 2008.

. La influencia de El misterio del capital de Hernando de Soto (1999). In: SMOLKA, Martin O. e MULLAHY, Laura (editores). Perspectivas urbanas, temas críticos em políticas de suelo em América Latina. Cambridge: Lincoln Institute of Land Police, 2007, pp.108-115.

. Perspectivas para a renovação das políticas de legalização de favelas no Brasil. In: ROLNIK, R., et al. Regularização fundiária sustentável - conceitos e diretrizes. Brasília: Ministério das Cidades, 2007.

FERREIRA, A. D. D. Agricultura Capitalista e Campesinato no Norte do Paraná - Região de Porecatu - 1940 - 52. Curitiba: UFPR. Dissertação de Mestrado, 1984.

FERREIRA, Y. N. Bolsões e pontos de pobreza de Londrina. Londrina: Revista Geografia UEL. ISSN 0102-388. v.8, n.1, p.65-82, jan.1999.

FISHER, L. R. C. E SIQUEIRA, L. A. A política de regularização fundiária urbana de interesse social: algumas conclusões a partir da pesquisa nas regiões Norte e Nordeste. In: Caminhos para as políticas de regularização fundiária no contexto da crise brasileira: resultados, avanços e obstáculos ('antigos' e 'novos'). Alex Ferreira Magalhães (Coord.). (Sessão Livre) Anais do XVII Enanpur. Encontro Nacional da Associação Nacional de PósGraduação e Pesquisa em Planejamento Urbano e Regional. São Paulo: FAUUSP, 2017.

FOUCAULT, M. Microfísica do poder. 13ed. Org e Trad. Roberto Machado. Rio de Janeiro: Graal, 1998.

Segurança, Território, População. Curso dado no College de France (1977-1978). Trad. Eduardo Brandão. São Paulo: Martins Fontes, 2008.

. A sociedade punitiva. Curso no College de France (1972-1973). Trad. Ivone C. Benedetti. São Paulo: Editora WMF Martins Fontes, 2015.

. Vigiar e Punir: nascimento da prisão. Trad. Raquel Ramalhete. 42.

Ed. Petrópolis: Vozes, 2014.

FRESCA, Tania Maria. Mudanças recentes na expansão físico-territorial de Londrina. Geografia. Londrina, v.11 n.2. p. 241-264, Jul/Dez. 2002.

; OLIVEIRA, Edilson L. de. A produção do espaço urbano de Londrina: 1970 - 2000. Londrina: Universidade Estadual de Londrina - Centro de Ciências Exatas - Departamento de Geociências. Relatório de Pesquisa (inédito), Maio de 2005. 
GAVETTI, N. A dignidade Política Administrativa. Por que tem que ser assim? Londrina: Cotação, 1998.

GILBERT, A. Love in the time of enhance capital flows: reflections on the links between liberalization and informality. In: ROY, A.; ALSAYYAD, N. Urban Informality. Transnational Perspectives from the Middle East, Latin America, and South Asia. Maryland: Lexington Books, 2004.

GONÇALVES, J. H. R. História regional e ideologias: em torno de algumas corografias políticas no norte paranaense - 1930/1980. Dissertação de mestrado. Curitiba: Universidade Federal do Paraná, 1995.

HARVEY, D. 1935. Os limites do capital [recurso eletrônico]. Tradução Magda Lopes. 1a.e.d. São Paulo: Boitempo, 2013.

- Do gerenciamento ao empresariamento: a transformação da administração urbana no capitalismo tardio. In Espaço e Debates, ano XVI, n. 39, 1996, pp. 48-64.

Las raíces urbanas de las crisis financeiras: reclamar la ciudad para la lucha anticapitalista. In: BELIL, M.; BORJA, J.; CORTI, M. Cidades, uma ecuación impossible. Barcelona: Icaria Editorial, 2012.

IPPUL. Habitação de baixa renda no âmbito municipal: habitação e políticas públicas em cidades médias - o caso de Londrina. Londrina, 1996.

LAVAL, C. Foucault, Bourdieu e a questão neoliberal. Conferência. Faculdade de Filosofia e Ciências Humanas da Universidade Federal da Bahia. 2018. Disponível em: https://www.youtube.com/watch?v=mnfAELfDSwE. Acesso em: 31/10/2019.

LAVAL, C.; DARDOT, P. La nueva razon Del mondo. Barcelona: Gedisa Editorial, 2013.

LEFEBVRE, H. A cidade do capital. Tradução de Maria Helena Rauta Ramos e Marilene Jamur. Rio de Janeiro: DP\&A, 1999.

UFMG, 2002. . A revolução urbana. Tradução de Sérgio Martins. Belo Horizonte: Ed. . Espaço e política. Tradução de Margarida Maria de Andrade e Sérgio Martins. Belo Horizonte: Ed. UFMG, 2008.

LONDRINA. PLHIS - Plano Local de Habitação de Interesse Social. Parte V. Diagnóstico da Precariedade Habitacional, 2011.

LONDRINA. PRI-BID. Plano de Reassentamento Involuntário - PRI de-Londrina. Programa de Desenvolvimento Urbano Sustentável de Londrina, 2012. 
LONDRINA. PEMAS. Plano Estratégico Municipal para Assentamentos Subnormais. Subprograma de Desenvolvimento Institucional. Programa Habitar Brasil/BID. Diagnóstico. 2002.

MAGALHÃES, A. O "legado" dos megaeventos esportivos: a reatualização da remoção de favelas no Rio de Janeiro. Horizontes Antropológicos, vol. 19, no 40, Porto Alegre, Jul/Dez. 2013.

MAGNANI, José Guilherme Cantor. De perto e de dentro: notas para uma etnografia urbana. Rev. Brasileira de Sociologia. [online]. 2002, vol.17, n.49, pp.11-29. ISSN 01026909. http://dx.doi.org/10.1590/S0102-69092002000200002

MARANHÃO, Tatiana. Governança mundial e pobreza. Do consenso de Washington ao consenso das oportunidades. Tese de Doutorado. USP, São Paulo, 2009.

MARICATO, E. Por um novo enfoque teórico na pesquisa sobre habitação. Cadernos metrópole 21 pp. 33-52 10 sem. 2009.

As idéias fora do lugar e o lugar fora das idéias: planejamento urbano no Brasil. In: ARANTES, O. et al. A cidade do pensamento único: desmanchando consensos. Petrópolis: Vozes, 2000.

MARTINS, V. H. T. Habitação, infraestrutura e serviços públicos. Conjuntos habitacionais e suas temporalidades em Londrina-PR. Dissertação de Mestrado. Universidade Estadual de Londrina, 2007.

; FRESCA, T. M. A Correção Monetária e a Produção dos Conjuntos Habitacionais: $O$ caso de Londrina. X Encontro de Geógrafos da América Latina, São Paulo, Março 2005. 8686 - 8706.

MELCHIOR, L., ASARI, A. Y. Ocupações urbanas de Londrina-PR e as migrações internas. Geografia, Volume 12, Número 1, Jan/Jun., 2003.

MISSE, M. Trocas ilícitas e mercadorias políticas: para uma interpretação de trocas ilícitas e moralmente reprováveis cuja persistência e abrangência no Brasil nos causam incômodos também teóricos. Anuário Antropológico, Brasília, UnB, 2010, v. 35, n. 2: 89107.

MOSCARELLI, F., \& KLEIMAN, M. (2017). Os desafios do planejamento e gestão urbana integrada no Brasil: análise da experiência do Ministério das Cidades. URBE. Revista Brasileira de Gestão Urbana, 9(2), 157-171. https://doi.org/10.1590/21753369.009.002.AO01

NEGRELOS, E. A moderna habitação econômica como questão de estado na produção capitalista da cidade. Fases de expansão e redução dos componentes modernos da cidade e da habitação no Brasil - Estado de São Paulo - no período 1930- 1986. URBANACIEC/UNICAMP. Dossiê: Cidade e Habitação na América Latina. V.6, no 8, jun.2014 
NOVELINO, Marcelo. Direito Constitucional. São Paulo: Editora Método, 2009, 3 ed., $362 / 364$.

OLIVEIRA, E. L. Divisão do trabalho e circuitos da economia urbana de Londrina. Tese de doutorado. São Paulo: Universidade de São Paulo, 2009.

OLIVEIRA, F. Crítica à razão dualista/O ornitorrinco. São Paulo: Boitempo Editorial, 2003.

. O Estado e a exceção ou o Estado de exceção? (2003). In: BARROS,

J.; SILVA, E. B.; DUARTE, L. Cidades e conflito: o urbano na produção do Brasil contemporâneo. Rio de Janeiro: FASE, 2013.

. O Estado e o urbano no Brasil (1982). In: BARROS, J.; SILVA, E. B.; DUARTE, L. Cidades e conflito: o urbano na produção do Brasil contemporâneo. Rio de Janeiro: FASE, 2013.

PACHUKANIS, E. Teoria geral do direito e marxismo. São Paulo: Editora Acadêmica, 1988.

PASTERNAK, S. A favela que virou cidade. In: VALENÇA, Márcio Moraes (org.). Cidade (i) legal. Rio de Janeiro: Mauad, 2008.

PIREZ, P. Las heterogéneas formas de producción y consumo de la urbanización latinoamericana. Quid 16 Revista del área de estydos urbanos del Instituto de Investigaciones Gino Germani de la Faculdade de Ciencias Sociales (UBA). №6 -2016- (131-167).

PRANDINI, Neide. Aspectos da Geografia Urbana em Londrina. 1952 IN: FRESCA, Tania Maria; CARVALHO, Márcia Siqueira de. Geografia do Norte do Paraná: Um resgate histórico. Londrina: Humanidades, 2007 v.2

POULANTZAS, N. Poder político e classes sociais. São Paulo: Martins Fontes, 1986.

PULHEZ, M. M. O arranjo gerencial: Estado, empresas de engenharia e arquitetos nos cotidianos de gestão da política habitacional de São Paulo. (Tese de doutorado). Universidade de São Paulo. São Carlos, 2014.

RICHTER, L. E. Princípio de Inscrição: considerações gerais. In: Revista de Direito Imobiliário n. 318, ano 27, Set./ Out. de 2004, p. 4.

RIZEK, C. S. Etnografias urbanas: cultura e cidade de dentro e de perto. Redobra, v. 4, n. 12, p. 19-24, nov., 2013.

. Os dados e seu sentido: algumas interrogações metodológicas em sociologia do trabalho. Caderno CRH, Salvador, n. 30/31, p. 319-337, jan./dez., 1999.

. Um balanço de pesquisa, 10 anos na zona leste e um social reconfigurado. In: Justiça e Direito: um debate sobre o urbano. Revista Cidades, V.13, $\mathrm{n}$-22, 2016. 
ROLNIK, R. [et al]. Regularização fundiária sustentável - conceitos e diretrizes. Brasília: Ministério das Cidades, 2007.2 Disponível em: http://www.urbanismo.mppr.mp.br/arquivos/File/Livro_Regularizacao_Fundiaria_Plen a_Referencias_Conceituais.pdf. Acesso em: 24/10/2019

ROLNIK, R. Guerra dos lugares: a colonização da terra e da moradia na era das finanças. 1a Ed. São Paulo: Boitempo, 2015

A cidade e a lei. Legislação, política urbana e territórios na cidade de São Paulo. Livros Studio Nobel: São Paulo, 1999.

ROSA, T. T. Cidades Outras: pobreza, moradia e mediações em trajetórias urbanas liminares. Tese de Doutorado. Universidade de São Paulo. São Carlos, 2015.

. Fronteiras em disputa na produção do espaço urbano: a trajetória do 'Gonzaga' de favela a bairro de periferia. Dissertação de mestrado. Universidade Estadual de Campinas. Campinas, 2008.

ROY, A. Cidades Faveladas. Repensando o urbanismo subalterno. e-metropolis. $\mathrm{n}-31$ ano 8, dezembro de 2017.

. Urban Informality: Toward an Epistemology of Planning. Journal of

the American Planning Association, 71:2, 147-158, 2007 DOI: 10.1080/01944360508976689

; ALSAYYAD, N. Urban Informality. Transnational Perspectives from the Middle East, Latin America, and South Asia. Maryland: Lexington Books, 2004.

RUFINO, M. B. Um olhar sobre a produção do PMCMV a partir de eixos analíticos. In: Santo Amore, C.; Shimbo, L.; Rufino, M. B. (org.) Minha casa... e a cidade? avaliação do programa minha casa minha vida em seis estados brasileiros. Rio de Janeiro: Letra Capital, 2015.

SAGMACS. Aspectos Humanos da favela carioca. O Estado de São Paulo, Suplemento Especial, 15 de abril de 1960. Parte geral, p.38)

SANTO AMORE, C. "Minha Casa Minha Vida" para iniciantes. In: SANTO AMORE, C.; SHIMBO, L.; RUFINO, M. B. (org.) Minha casa... e a cidade? avaliação do programa minha casa minha vida em seis estados brasileiros. Rio de Janeiro: Letra Capital, 2015.

. Entre o nó e o fato consumado, o lugar dos pobres na cidade: um estudo sobre as ZEIS e os impasses da reforma urbana na atualidade. Tese doutorado. FAUUSP, São Paulo, 2013.

; SHIMBO, L.; RUFINO, M. B. (org.) Minha casa... e a cidade? avaliação do programa minha casa minha vida em seis estados brasileiros. Rio de Janeiro: Letra Capital, 2015. 
SANTOS, C. N. F. dos. A Cidade como um jogo de cartas. Niterói: Universidade Federal Fluminense: EDUF; São Paulo: Projeto Editores, 1988.

SANTOS, J. R. PROGRAMA HABITAR BRASIL II NA ZONA NORTE DE LONDRINA: O remanejamento da população do fundo de vale da microbacia do córrego Sem Dúvida. Trabalho apresentado como requisito para Conclusão do Curso de Bacharelado em Geografia, Universidade Estadual de Londrina, 2010.

SCHWARZ, R. Ao Vencedor As Batatas. São Paulo: Duas Cidades, 1992, 4. ed.

SERRAN, J. R. O IAB e a política habitacional brasileira - 1954-1975. São Paulo: Schema, 1976.

SHIMBO, L. Habitação social, habitação de mercado: a confluência entre Estado, empresas construtoras e capital financeiro. Tese de doutorado. Escola de Engenharia de São Carlos da Universidade de São Carlos, São Carlos, 2010.

SILVA, A. A propriedade sem registro: o contrato e a aquisição da propriedade imóvel na perspectiva civil-constitucional. Tese de doutorado. Curitiba: UFPR, 2014.

SILVA, S. H. BONI, P. C. Avenida Higienópolis: um retrato da burguesia londrinense nas décadas de 30, 40, 50 e 60. VII Encontro Nacional de História da Mídia, realizado em Fortaleza (CE), de 19 a 21 de agosto de 2009.

SILVA, W. R., MERCHIOR, L. Estruturação Urbana sob o contexto da mobilidade populacional em Londrina-Brasil. Revista Bibliográfica de Geografía y Ciencias Sociales. Universidade de Barcelona. Vol. VII, no 314, 10 de enero de 2002.

SINGER, A. Os sentidos do Lulismo: reforma gradual e pacto conservador. São Paulo: Companhia das Letras, 2012.

DE SOTO, H. The Mystery of Capital. Why Capitalism Triumphs in the West and Fails Everywere Else. Black Swan: London, 2000. [Epub ISBN: 9781409057864]

STRATHERN, M. O efeito etnográfico. In: O efeito etnográfico e outros ensaios. São Paulo: Cosac Naify, 2014.

TELLES, V.; HIRATA, D. Ilegalismos e jogos de poder em São Paulo. Tempo Social, v. 22, n. 2, dezembro, 2010. ISSN 0103-2070

TELLES, V.; CABANES, R. (org). Nas tramas da cidade: trajetórias urbanas e seus territórios. São Paulo: Associação Editorial Humanitas, 2006.

TELLES, V. S. Debates: a cidade como questão. In: TELLES, V. S. e CABANES, R. (org.) Nas tramas da cidade: trajetórias urbanas e seus territórios. São Paulo: Associação Editorial Humanitas, 2006. 
Trajetórias urbanas: fios de uma descrição da cidade. In: TELLES, V. S. e CABANES, R. (org.) Nas tramas da cidade: trajetórias urbanas e seus territórios. São Paulo: Associação Editorial Humanitas, 2006.

As fronteiras da lei como campo de disputas. in: PERALVA, A.; TELLES, V. S. Ilegalismos na globalização: migração, trabalho e mercados RJ: UFRJ Editora, 2015.

TOCHETTO, D. Ferraz, C. O urbanismo de Saturnino de Brito e as ressonâncias provocadas. Risco. Revista de pesquisa em arquitetura e urbanismo. Instituto de Arquitetura e Urbanismo IAU-USP n22, 2/2015.

TOMAZI, N. D. "Norte do Paraná". Histórias e fantasmagorias. Tese de doutorado. Curitiba: Universidade Federal do Paraná, 1997.

VAINER, C. Pátria, empresa e mercadoria: a estratégia discursiva do Planejamento Estratégico Urbano". In: Arantes, O.; Maricato, E.; Vainer, C. A cidade do Pensamento Único. Desmanchando Consensos. Petrópolis: Vozes, 2000, pp. 105-119.

Cidade de exceção: reflexões a partir do Rio de Janeiro. Anais: Encontros Nacionais da ANPUR. XIV Encontro Nacional da ANPUR. Rio de Janeiro, 2011.

VAlLADARES, L. P. Passa-se uma casa. Análise do Programa de Remoção de Favelas do Rio de Janeiro. Rio de Janeiro: Zahar Editores, 1978.

YAMAKI, H. Iconografia Londrinense. Londrina: Edições Humanidades, 2003.

Humanidades, 2006.

Labirinto da memória: paisagens de Londrina. Londrina: Edições . Terras do norte: paisagem e morfologia. Londrina: Ed. H. Yamaki e UEL, 2017. 


\section{Sites Consultados:}

Folha de Londrina (1997).

Disponível em: https://www.folhadelondrina.com.br/cidades/federacao-das-favelas-ecohab-querem-por-fim-a-venda-de-lotes-33869.html. Acesso em 30/10/219.

Folha de Londrina (1999).

Disponível em: https://www.folhadelondrina.com.br/cidades/cohab-compra-terrenoinvadido-235181.html. (Acesso em: 29/10/2019).

Folha de Londrina (2001).

Disponível em: https://www.folhadelondrina.com.br/reportagem/favelas-concentramcarentes-desde-1966-341194.html. Acesso em: 29/10/2019.

Folha de Londrina (2001).

Disponível em: https://www.folhadelondrina.com.br/reportagem/favelas-concentramcarentes-desde-1966-341194.html. Acesso em 30/10/219.

Cohapar (2004).

Disponível em:

http://www.cohapar.pr.gov.br/modules/noticias/article.php?storyid=139. Acesso em: $27 / 10 / 2019$.

Folha de Londrina (2006).

Disponível em: https://www.folhadelondrina.com.br/geral/familias-urbanizamterreno-invadido-555173.html. Acesso em: 01/05/2019.

Folha de Londrina (2008).

Disponível em: https://www.folhadelondrina.com.br/cidades/fazenda-refugio-terrade-ninguem-645048.html. Acesso em: 29/10/2019.

Prefeitura Municipal de Londrina (2009)

Disponível em:

http://www.londrina.pr.gov.br/index.php?option=com_content\&view=article\&id=140 68\%3Agestao-barbosa-neto-regulariza-1295-terrenos-em-

londrina\&catid=108\%3Adestaques\&ltemid=288. Acesso em: 26/10/2019

Gazeta do Povo (2012).

Disponível em: https://www.gazetadopovo.com.br/vida-publica/gestao-de-barbosaneto-foi-polemica-desde-o-inicio-35trw1i4lo1f5yggdtynm8fny/. Acesso em: $30 / 10 / 2019$

Norte e Noroeste RPC (2016). 
Disponível em: http://g1.globo.com/pr/norte-noroeste/noticia/2016/05/barbosa-netoex-prefeito-de-londrina-e-novamente-denunciado-pelo-mp-pr.html. Acesso em: $30 / 10 / 2019$

Bonde (2016).

Disponível em: https://www.bonde.com.br/bondenews/politica/ex-prefeito-barbosaneto-e-condenado-por-improbidade-administrativa-412931.html. Acesso em: $30 / 10 / 2019$

Programa Doing Business. Banco Mundial (2019).

Disponível em: https://portugues.doingbusiness.org/pt/doingbusiness. Acesso em: 28/10/2019.

\section{Leis Consultadas:}

Lei de Terras de 1850 (Lei Imperial no 601 de 1850). Dispõe sobre as terras devolutas do Império.

Lei Federal no 4.504 de 1964. Dispõe sobre o estatuto da terra, e dá outras providências.

Decreto-Lei no 271 de 1967. Dispõe sobre loteamento urbano, responsabilidade do loteador concessão de uso e espaço aéreo e dá outras providências.

Decreto-Lei no 200 de 1967. Dispõe sobre a organização da Administração Federal, estabelece diretrizes para a Reforma Administrativa e dá outras providências.

Lei Federal no 6.015 de 1973. Dispõe sobre os registros públicos, e dá outras providências.

Lei Federal no 6.766 de 1979. Dispõe sobre o Parcelamento do Solo Urbano e dá outras Providências.

\section{Constituição da República Federativa do Brasil de 1988.}

Lei Federal no 8.666 de 1993. Regulamenta o art. 37, inciso XXI, da Constituição Federal, institui normas para licitações e contratos da Administração Pública e dá outras providências.

Lei no 8.935 de 1994. Regulamenta o art. 236 da Constituição Federal, dispondo sobre serviços notariais e de registro. (Lei dos cartórios).

Lei Federal no 9.514 de 1997. Dispõe sobre o sistema de financiamento imobiliário, institui a alienação fiduciária de coisa imóvel e dá outras providências.

Lei Federal no 10.257 de 2001. Regulamenta os arts. 182 e 183 da Constituição Federal, estabelece diretrizes gerais da política urbana e dá outras providências.

Lei Federal no 10.931 de 2004. Dispõe sobre o patrimônio de afetação de incorporações imobiliárias, Letra de Crédito Imobiliário, Cédula de Crédito Imobiliário, Cédula de 
Crédito Bancário, altera o Decreto-Lei no 911, de 10 de outubro de 1969, as Leis no 4.591, de 16 de dezembro de 1964, no 4.728, de 14 de julho de 1965, e no 10.406, de 10 de janeiro de 2002, e dá outras providências.

Lei Federal no 11.124 de 2005. Dispõe sobre o Sistema Nacional de Habitação de Interesse Social - SNHIS, cria o Fundo Nacional de Habitação de Interesse Social - FNHIS e institui o Conselho Gestor do FNHIS.

Resolução do Conama no 369, de 28 de março de 2006. Dispõe sobre os casos excepcionais, de utilidade pública, interesse social ou baixo impacto ambiental, que possibilitam a intervenção ou supressão de vegetação em Área de Preservação Permanente-APP.

Lei Federal no 11.481 de 2007. Dá nova redação a dispositivos das Leis nos 9.636, de 15 de maio de 1998, 8.666, de 21 de junho de 1993, 11.124, de 16 de junho de 2005, 10.406, de 10 de janeiro de 2002 - Código Civil, 9.514, de 20 de novembro de 1997, e 6.015, de 31 de dezembro de 1973, e dos Decretos-Leis nos 9.760, de 5 de setembro de 1946, 271, de 28 de fevereiro de 1967, 1.876, de 15 de julho de 1981, e 2.398, de 21 de dezembro de 1987; prevê medidas voltadas à regularização fundiária de interesse social em imóveis da União; e dá outras providências.

Lei Federal no 11.977 de 2009. Dispõe sobre o Programa Minha Casa, Minha Vida PMCMV e a regularização fundiária de assentamentos localizados em áreas urbanas; altera o Decreto-Lei no 3.365, de 21 de junho de 1941, as Leis nos 4.380, de 21 de agosto de 1964, 6.015, de 31 de dezembro de 1973, 8.036, de 11 de maio de 1990, e 10.257, de 10 de julho de 2001, e a Medida Provisória no 2.197-43, de 24 de agosto de 2001; e dá outras providências.

Lei Federal no 12.242 de 2011. Altera a Lei no 11.977, de 7 de julho de 2009, que dispõe sobre o Programa Minha Casa, Minha Vida - PMCMV e a regularização fundiária de assentamentos localizados em áreas urbanas, as Leis $\mathrm{n}$-s 10.188 , de 12 de fevereiro de 2001, 6.015, de 31 de dezembro de 1973, 6.766, de 19 de dezembro de 1979, 4.591, de 16 de dezembro de 1964, 8.212, de 24 de julho de 1991, e 10.406, de 10 de janeiro de 2002 - Código Civil; revoga dispositivos da Medida Provisória no 2.197-43, de 24 de agosto de 2001; e dá outras providências.

Lei no 12.651 de 2012. Dispõe sobre a proteção da vegetação nativa; altera as Leis nos 6.938, de 31 de agosto de 1981, 9.393, de 19 de dezembro de 1996, e 11.428, de 22 de dezembro de 2006; revoga as Leis nㅇ 4.771, de 15 de setembro de 1965, e 7.754, de 14 de abril de 1989, e a Medida Provisória no 2.166-67, de 24 de agosto de 2001; e dá outras providências.

Lei Federal no 13.097 de 2015. Reduz a zero as alíquotas da Contribuição para o PIS/PASEP, da COFINS, da Contribuição para o PIS/Pasep-Importação e da CofinsImportação incidentes sobre a receita de vendas e na importação de partes utilizadas em aerogeradores; prorroga os benefícios previstos nas Leis $\mathrm{n} \cong 9.250$, de 26 de dezembro de 1995, 9.440, de 14 de março de 1997, 10.931, de 2 de agosto de 2004, 11.196, de 21 de novembro de 2005, 12.024, de 27 de agosto de 2009, e 12.375, de 30 de dezembro de 2010; altera o art. 46 da Lei no 12.715, de 17 de setembro de 2012, que 
dispõe sobre a devolução ao exterior ou a destruição de mercadoria estrangeira cuja importação não seja autorizada; altera as Leis $\mathrm{n} \cong 9.430$, de 27 de dezembro de 1996, 12.546, de 14 de dezembro de 2011, 12.973, de 13 de maio de 2014, 9.826, de 23 de agosto de 1999, 10.833, de 29 de dezembro de 2003, 10.865, de 30 de abril de 2004, 11.051, de 29 de dezembro de 2004, 11.774, de 17 de setembro de 2008, 10.637, de 30 de dezembro de 2002, 12.249, de 11 de junho de 2010, 10.522, de 19 de julho de 2002, 12.865, de 9 de outubro de 2013, 10.820, de 17 de dezembro de 2003, 6.634, de 2 de maio de 1979, 7.433, de 18 de dezembro de 1985, 11.977, de 7 de julho de 2009, 10.931, de 2 de agosto de 2004, 11.076, de 30 de dezembro de 2004, 9.514, de 20 de novembro de 1997, 9.427, de 26 de dezembro de 1996, 9.074, de 7 de julho de 1995, 12.783, de 11 de janeiro de 2013, 11.943, de 28 de maio de 2009, 10.848, de 15 de março de 2004, 7.565, de 19 de dezembro de 1986, 12.462, de 4 de agosto de 2011, 9.503, de 23 de setembro de 1997, 11.442, de 5 de janeiro de 2007, 8.666, de 21 de junho de 1993, 9.782, de 26 de janeiro de 1999, 6.360, de 23 de setembro de 1976, 5.991, de 17 de dezembro de 1973, 12.850, de 2 de agosto de 2013, 5.070, de 7 de julho de 1966, 9.472, de 16 de julho de 1997, 10.480, de 2 de julho de 2002, 8.112, de 11 de dezembro de 1990, 6.530, de 12 de maio de 1978, 5.764, de 16 de dezembro de 1971, 8.080, de 19 de setembro de 1990, 11.079, de 30 de dezembro de 2004, 13.043, de 13 de novembro de 2014, 8.987, de 13 de fevereiro de 1995, 10.925, de 23 de julho de 2004, 12.096, de 24 de novembro de 2009, 11.482, de 31 de maio de 2007, 7.713, de 22 de dezembro de 1988, a Lei Complementar no 123, de 14 de dezembro de 2006, o Decreto-Lei no 745, de 7 de agosto de 1969, e o Decreto no 70.235, de 6 de março de 1972; revoga dispositivos das Leis $\mathrm{n}$ o 4.380, de 21 de agosto de 1964, 6.360, de 23 de setembro de 1976, 7.789, de 23 de novembro de 1989, 8.666, de 21 de junho de 1993, 9.782, de 26 de janeiro de 1999, 10.150, de 21 de dezembro de 2000, 9.430, de 27 de dezembro de 1996, 12.973, de 13 de maio de 2014, 8.177, de 1 o de março de 1991, 10.637, de 30 de dezembro de 2002, 10.833, de 29 de dezembro de 2003, 10.865, de 30 de abril de 2004, 11.051, de 29 de dezembro de 2004 e 9.514, de 20 de novembro de 1997, e do Decreto-Lei no 3.365, de 21 de junho de 1941; e dá outras providências.

Lei Federal no 13.465 de 2017. Dispõe sobre a regularização fundiária rural e urbana, sobre a liquidação de créditos concedidos aos assentados da reforma agrária e sobre a regularização fundiária no âmbito da Amazônia Legal; institui mecanismos para aprimorar a eficiência dos procedimentos de alienação de imóveis da União; altera as Leis $\mathrm{n}$ os 8.629, de 25 de fevereiro de 1993 , 13.001, de 20 de junho de 2014 , 11.952, de 25 de junho de 2009, 13.340, de 28 de setembro de 2016, 8.666, de 21 de junho de 1993, 6.015, de 31 de dezembro de 1973, 12.512, de 14 de outubro de 2011 , 10.406, de 10 de janeiro de 2002 (Código Civil), 13.105, de 16 de março de 2015 (Código de Processo Civil), 11.977, de 7 de julho de 2009, 9.514, de 20 de novembro de 1997, 11.124, de 16 de junho de 2005, 6.766, de 19 de dezembro de 1979, 10.257, de 10 de julho de 2001, 12.651, de 25 de maio de 2012, 13.240, de 30 de dezembro de 2015, 9.636, de 15 de maio de 1998, 8.036, de 11 de maio de 1990, 13.139, de 26 de junho de 2015, 11.483, de 31 de maio de 2007, e a 12.712, de 30 de agosto de 2012, a Medida Provisória no 2.220, de 4 de setembro de 2001, e os Decretos-Leis n 02.398 , de 21 de dezembro de 1987, 1.876, de 15 de julho de 1981, 9.760, de 5 de setembro de 1946, e 
3.365, de 21 de junho de 1941; revoga dispositivos da Lei Complementar no 76, de 6 de julho de 1993, e da Lei no 13.347, de 10 de outubro de 2016; e dá outras providências.

Lei Municipal no 133 de 51. Dispõe sobre arruamentos, loteamentos e zoneamento.

Lei Municipal no 1.008 de 1965. Autoriza o Executivo Municipal a constituir a COMPANHIA DE HABITAÇÃO DE LONDRINA - COHAB-LD.

Lei Municipal no 5526 de 1993. Dispõe sobre a criação do Fundo Municipal de Habitação e constituição do Conselho Municipal de Habitação e dá outras providências.

Lei Municipal no 9.866 de 2005. Inclui meta na Lei Municipal no 8.659, de 19 de dezembro de 2001 - Plano Plurianual - PPA, e no anexo de metas e prioridades da Lei Municipal no 9.559, de 5 de julho de 2004 - Lei de Diretrizes Orçamentárias - LDO; autoriza a abertura de crédito adicional especial da quantia até $\mathrm{R} \$ 215.000 .000,00$ junto aos encargos do município; autoriza a operação de crédito com a Caixa Econômica Federal e a transferência de títulos CVS à Companhia de Habitação de Londrina - COHABLD; institui o programa de reciclagem de ativos do Sistema Financeiro da Habitação SFH e de regularização fundiária de assentamentos urbanos e dá outras providências.

Lei Municipal no $\mathbf{1 0 . 6 1 8}$ de 2008. Altera o $\S 1$ ㅇ do artigo 10 e o artigo 17, ambos da Lei 9.866, de 20de dezembro de 2005.

Lei Municipal no $\mathbf{1 2 . 2 1 5}$ de 2014. Altera o artigo 17 da Lei no 9.866, de 20 de dezembro de 2005, alterada pela Lei no 10.618 , de 22 de dezembro de 2008, pela Lei $n=11.208$, de 11 de maio de 2011 e pela Lei no 11.456, de 22 de dezembro de 2011. 
